\title{
Pandemics and Political Development: The Electoral Legacy of the Black Death in Germany
}

\author{
(Working Paper*)
}

\author{
Daniel W. Gingerich, University of Virginia (dwg4c@virginia.edu) \\ Jan P. Vogler, University of Virginia (jv2mc@virginia.edu)
}

November 7, 2020

\begin{abstract}
Do pandemics have lasting consequences for political behavior? We address this question by examining the consequences of the most deadly pandemic of the last millennium: the Black Death (1347-1351). Our claim is that pandemics can influence politics in the long run if they impose sufficient loss of life so as to augment the price of labor relative to other factors of production. When this occurs, labor repressive regimes (such as serfdom) become untenable, which ultimately leads to the development of proto-democratic institutions and associated political cultures that shape modalities of political engagement for generations. We test our theory by tracing out the local consequences of the Black Death in German-speaking Central Europe. We find that areas hit hardest by the pandemic were more likely to: (1) adopt inclusive political institutions and equitable land ownership patterns; (2) exhibit electoral behavior indicating independence from landed elite influence during the transition to mass politics; and (3) have significantly lower vote shares for Hitler's National Socialist Party in the Weimar Republic's fateful 1930 and July 1932 elections.

* Comments are welcome.
\end{abstract}

The most recent version of this paper may be obtained at the following URL:

Download the most recent version of the paper at this link. 


\section{Acknowledgments}

Helpful comments have been provided by Lasse Aaskoven, Manuela Achilles, John Aldrich, Shan Aman-Rana, Margaret Anderson, Kyle Beardsley, Pablo Beramendi, Carles Boix, Ernesto Calvo, Paweł Charasz, Volha Charnysh, Alexandra Cirone, Kerem Cosar, Paul Freedman, Jeff Frieden, Olga Gasparyan, Michael Gillespie, Robert Gulotty, Connor Huff, Noel Johnson, Stefano Jud, Justin Kirkland, Herbert Kitschelt, Mark Koyama, Markus Kreuzer, Eroll Kuhn, Erin Lambert, Michael Lindner, David Luebke, Eddy Malesky, Lucy Martin, Mat McCubbins, Christian McMillen, Ralf Meisenzahl, Carl Müller-Crepon, Rachel Myrick, Nicola Nones, Sonal Pandya, Joan Ricart-Huguet, Ron Rogowski, Jim Savage, Walter Scheidel, Hanna Schwank, Emily Sellars, Renard Sexton, Jonathan Sperber, David Stasavage, Tilko Swalve, Georg Vanberg, Emily VanMeter, Nico Voigtländer, Fabian Wahl, David Waldner, Peter White, and Erik Wibbels. Moreover, we thank Jonathan Sperber for providing us with data on electoral outcomes in Imperial Germany; Mark Koyama, Boris Schmid, Ulf Büntgen, and Christian Ginzler for providing us with data on recorded outbreaks of the Black Death; Sascha Becker, Erik Hornung, and the Ifo Institute for Economic Research for additional information on the ifo Prussian Economic History Database (iPEHD); and Sean Morris for excellent research assistance. We gratefully acknowledge generous funding by the Corruption Laboratory for Ethics, Accountability, and the Rule of Law (CLEAR Lab), which is part of the Democracy Initiative at the University of Virginia. Finally, the development of our paper has profited significantly from virtual seminars at Duke University, the University of Virginia, the Global Research in International Political Economy (GRIPE) Webinar, the Virtual Workshop in Historical Political Economy (VWHPE), the Southern Workshop in Empirical Political Science (SoWEPS), and APSA's annual meeting. 


\section{Introduction}

Pandemics have shaped the course of human history, felling tottering empires, influencing colonization patterns, and endowing populations with competitive advantages. In specific circumstances, they can also restructure labor markets, with potentially drastic consequences for inequality and social organization (Scheidel, 2017). Indeed, if the demographic shock imposed by a pandemic is sufficiently profound, it may fundamentally reconfigure the relative bargaining power of labor versus capital. This raises the possibility that pandemics may hold implications for the substance and conduct of politics in the long run.

This paper studies the long-term political impact of pandemic disease shocks by examining the localized consequences of the most deadly pandemic of the last millennium: the Black Death (1347-1351). The Black Death was an outbreak of plague that devastated Europe, resulting in a loss of life estimated at between thirty and sixty per cent of its total population. Figure 1 shows recorded outbreaks at the town level across the continent based on data by Jedwab, Johnson and Koyama (2019a).

Among its many consequences, the Black Death radically altered relative factor prices. By culling the labor force but leaving land and capital assets intact, it transformed labor from an abundant to a scarce resource. The economic consequences were immediate and longlasting. ${ }^{1}$ For Western Europe, the pandemic ushered in an era of higher real wages - lasting approximately 250 years - along with a lessening of the obligations imposed on peasants in the manorial economy (Hilton, 1969; Pamuk, 2007).

\footnotetext{
${ }^{1}$ The depth of the economic shock imparted by the Black Death may be unparalleled. Lead readings taken from an ice core in the Swiss-Italian Alps indicate that metal production during the Black Death outbreak was lower than at any other point in the last 2000 years of human history (More, Spaulding, Bohleber, Handley, Hoffmann, Korotkikh, Kurbatov, Loveluck, Sneed and McCormick, 2017).
} 
Figure 1: Recorded Black Death Outbreaks and Mortality Rates Across Europe

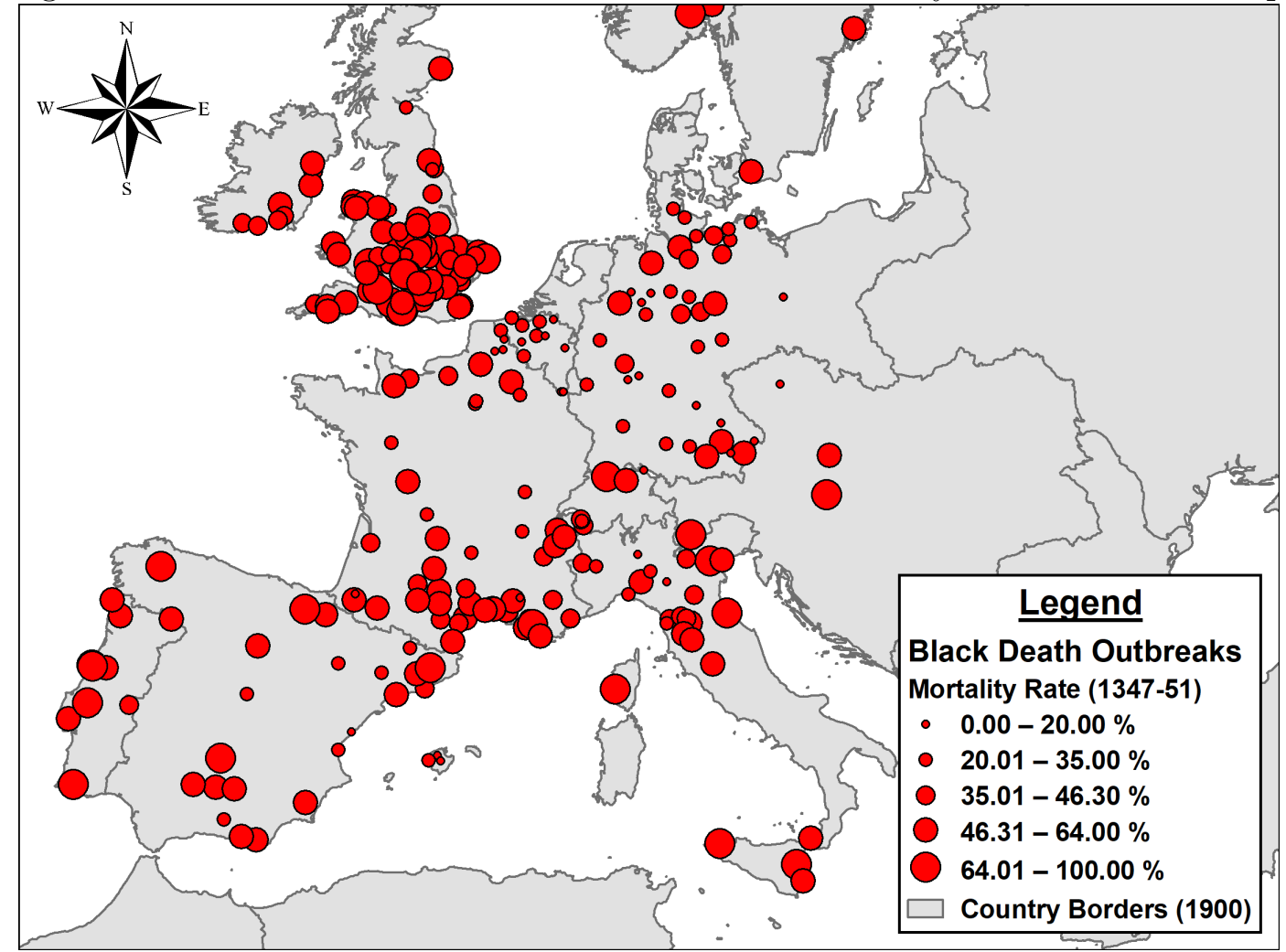

The macro-level implications of the Black Death for economic development have been an object of inquiry for many years. Economic historians have argued that the Black Death led to the end of the Middle Age's so-called Malthusian trap, generating a shift from subsistence agriculture to economic production characterized by greater urbanization, increasing manufacturing capacity, technological development, and sustained growth (Herlihy, 1997; Postan, 1966; Voigtländer and Voth, 2013). These changes made possible the fiscal infrastructure necessary to support standing armies and create nation-states (North and Thomas, 1973). Given its epochal importance for economic organization, the Black Death is widely considered to have produced one of the most important critical junctures in recorded human history. Indeed, it is thought to be the starting point for what ultimately became large divergences in development between Western and Eastern Europe (Acemoglu and Robinson, 2012) as well as Western Europe and China (Voigtländer and Voth, 2013). 
Due to the pioneering data collection effort of Christakos, Olea, Serre, Wang and Yu (2005), the Black Death's local-level consequences have also recently become an object of scholarly inquiry. Researchers have traced out the long-run consequences of Black Death intensity for city growth (Jedwab, Johnson and Koyama, 2019b), the timing of the demographic transition (Siuda and Sunde, 2019), and the persecution of religious minorities (Finley and Koyama, 2018; Jedwab, Johnson and Koyama, 2019a). Others have examined the impact of plague shocks more generally on public goods institutions that shape the accumulation of human capital (Dittmar and Meisenzahl, 2019). These important advances notwithstanding, the Black Death's local-level consequences for political organization and behavior have yet to receive empirical scrutiny.

This is consistent with a general pattern of neglect within the discipline of political science. Despite the Black Death's prominent place in accounts of long-term economic development, it receives remarkably short shrift in treatments of the development of political representation and mass political behavior. For instance, the canonical investigation by Moore (1966) into the social origins of political regimes offers only a single passing reference to the Black Death (for the case of England); the foundational study by Rokkan (1970) of the origins of party politics in Europe ignores it entirely. The classic political histories of European state formation are similarly neglectful of the Black Death: Strayer (1973) and Tilly (1990) only mention it off-hand in general discussions of war and city growth. There are exceptions: Peters (2018) studies the consequences of credit market access for patterns of labor coercion in the aftermath of the Black Death. Yet consistent with earlier scholarship (Blum, 1957; Brenner, 1976), this work treats the Black Death as a uniform shock, concentrating its analyses on differences in initial conditions instead of the variegated impact of the disease. 
We depart ways with existing scholarship by focusing systematically on the political implications of geographical variation in the loss of life caused by the Black Death. Specifically, using geocoded data on Black Death mortality rates, our paper examines the long-run socioeconomic and political consequences of localized Black Death exposure. The core of our study concentrates on the legacies of the Black Death for electoral behavior and land tenure patterns in Imperial Germany during the dawn of mass politics at the end of the nineteenth century. Additionally, we complement these findings with analyses that assess the effects of the Black Death at both earlier and later periods of history. For the pre-Reformation (pre1517) period, we study the link between exposure to the Black Death and the emergence of early forms of participative institutions. For the period of full-fledged mass democracy (1918-1933), we identify the lingering effects of the democratic cultures bequeathed by the Black Death for patterns of voting behavior in the Weimar Republic.

The historical experience of the German cultural area is particularly apposite for evaluating the Black Death's long-term political consequences. This area was marked by significant regional variation in the mortality caused by the Black Death, making feasible the identification of distinct outcome patterns associated with differing levels of exposure to the outbreak. Equally important, there was no single, absolute ruler or other centralized political regime that governed the German-speaking territories. To the contrary, from the medieval period to the onset of Imperial Germany, German-speaking Europe was made up of a decentralized patchwork of principalities, duchies, free cities, and other administrative units. This high level of decentralization created a context in which local political cultures, borne from the initial reactions to demographic collapse, had sufficient space to implant themselves and become more distinctive over time.

Our central contention is that the long-lived regional political cultures attributable to the 
Black Death significantly shaped patterns of political participation up until the early days of the German Empire's foundation and exhibited a weaker but still perceptible influence in the decades that followed. There are three steps in our argument.

First, differences in Black Death mortality led to differences in the persistence and depth of labor coercion during the early modern period (fourteenth/fifteenth centuries to late eighteenth century). In areas where the Black Death hit hard, elites were forced to abandon serfdom for an incipient free labor regime. By contrast, in areas where the toll of the Black Death was relatively mild, customary labor obligations were maintained (or even amplified).

Second, regional differences in the use of labor coercion, in turn, led to a divergence in socioeconomic and political organization. In areas where serfdom receded, the new freedoms granted to laborers encouraged the development of institutions for (limited) local selfgovernment, produced greater employment outside of agriculture, and led to greater equality in landholding. In areas where serfdom was maintained or became more onerous, the development of participative institutions for local self-government was inhibited, the agricultural economy remained dominant, and high levels of inequality in landholding persisted over time.

Finally, with the advent of mass electoral politics in the late nineteenth century, the societal conditions generated by the distinct legacies of labor coercion shaped voters' electoral decisions. In the areas characterized by participatory institutions and relative equality, voters were inclined to reject the guidance of traditional elites, leading to weak support for conservative parties and stronger support for liberal parties. Contrariwise, in the areas characterized by less inclusive institutions and high inequality, voters were more inclined to defer to the directives of traditional elites, leading to strong support for conservative parties and weaker support for liberal parties. Stated simply, strong Black Death shocks favored abbreviated experiences with serfdom, greater self-government, and ultimately receptive- 
ness to horizontally-oriented and inclusive political parties; contrariwise, weak Black Death shocks favored prolonged experiences with serfdom, lesser self-government, and ultimately receptiveness to parties with a hierarchical and illiberal orientation.

Our main empirical findings are consistent with these expectations. Using district-level electoral data from the 1871 legislative elections of Imperial Germany, we find that geographical variation in exposure to the Black Death is strongly and negatively related to the percentage of the vote won by the Conservative Party - a party that was strongly antidemocratic in its means and ends. Moreover, we find that areas least affected by the Black Death were characterized by societal conditions in which the Conservative Party was likely to thrive. In particular, we find that landholding inequality in the late nineteenth century was significantly greater in areas with mild exposure to the Black Death than in areas where it had a profound impact.

In addition, our complementary analyses support both the tenor and mechanisms of our argument. The analysis of the pre-Reformation period provides evidence for our overarching claim that the intensity of Black Death exposure was positively associated with subsequent changes in key aspects of political development. Specifically, we demonstrate that areas hit hard by the Black Death were more likely to experience the introduction of local participative elections from 1300 (pre-Black Death) to 1500 (post-Black Death) than areas that were not similarly affected. This gives us confidence that the Black Death encouraged the development of distinctive regional political traditions that shaped political behavior in the long run. The analysis of the Weimar Republic, in turn, provides evidence that the link between Black Death exposure and support for illiberal parties is not an artifact of the idiosyncrasies of politics in early Imperial Germany. Examining spatial variation in the vote share of the Nazi party (Nationalsozialistische Arbeiterpartei Deutschlands, NSDAP) in the 1930 and 
July 1932 German federal elections, we find that areas that had experienced high levels of exposure to the Black Death exhibited significantly lower levels of electoral support for the Nazis than areas that had experienced low levels of exposure. This gives us confidence that the regional political traditions that we attribute to the Black Death were robust and played a crucial role in German electoral politics during pivotal moments of the nation's history.

The remainder of this paper is organized as follows. First, we outline our contribution relative to existing studies of labor coercion and the long-run consequences of infectious diseases. Second, we provide a theory of how the Black Death impacted relative factor prices and the feasibility of labor coercion. Third, we introduce the empirical case and highlight the dimensions of greatest relevance to our study. Thereafter, we outline the framework of our empirical test. After a discussion of the results, we conclude and consider possible implications of our study.

\section{Pandemics, Factor Prices, and Labor Coercion}

Pandemics impose death, sometimes at a massive scale. When a pandemic produces a major demographic collapse, it can also change relative factor prices: the economic returns to labor versus land and/or capital. This may lead to substantial changes in economic and political organization. It is widely appreciated that differences in factor prices shape economic inequality (Piketty, 2014; Piketty and Saez, 2014), which, in turn, affects both the incidence of democracy (Acemoglu and Robinson, 2006; Ansell and Samuels, 2014; Boix, 2003) as well as the quality of democratic representation (Bartels, 2008; Gilens, 2012; Uslaner, 2008).

In spite of the fact that factor prices are axes of social organization, pinpointing empirically how they shape political life can be challenging. As relative factor prices delimit 
the bargaining power of social groups, they both shape and are shaped by public policies (Beramendi and Anderson, 2008; Hall and Soskice, 2001; Rogowski, 1989). The same can be said for political institutions, which structure how public policies are made (Acemoglu, 2010; Persson and Tabellini, 2000).

Since the causal arrow relating factor prices to policies and institutions goes in both directions, isolating the influence of the former requires one to identify an appropriate exogenous shock. The Black Death offers a good historical example of such a shock. Caused by the bacterium Yersinia pestis and transmitted to humans by infected rat fleas (and subsequently via human-to-human contact in its pneumonic strain), the etiology of the Black Death was completely unknown to medicine at the time (Snowden, 2019, 52-53, 69). Consequently, neither differences in rudimentary public health procedures nor preexisting levels of economic development appeared to determine its timing or intensity (cf. Christakos et al., 2005; Gottfried, 1983). Proximity to trade routes was clearly important, but conditional on trade exposure plague mortality was nearly random (Benedictow, 2004; Yue, Lee and Wu, 2017). ${ }^{2}$ Unlike contemporary pandemics, the Black Death did not overtly discriminate based on social status: It cut down both the wealthy and poor, claiming the lives of the King of Castile, large swathes of the clergy, and countless peasants. ${ }^{3}$ At the same time, the intensity of the Black Death varied greatly across space. ${ }^{4}$ These special features of the Black Death make it possible to discern the long-term influence of Black Death mortality, and, ipso facto, changes in relative factor prices, by employing a standard suite of econometric tools.

\footnotetext{
${ }^{2}$ Importantly, the historical intensity of the plague was unrelated to the size of affected settlements, indicating that severe outbreaks occurred even in sparsely populated and rural areas (Campbell, 2016, 303).

${ }^{3}$ While the plague's mortality rate was very high among the poorest, who were often malnourished and lived in poor sanitary conditions, better situated members of society were by no means excluded and also died in large numbers (Campbell, 2016).

${ }^{4}$ The German cities of Bremen and Nuremberg illustrate this fact. Although both were roughly the same size, Bremen lost between one half to two thirds of its population while Nuremberg only lost ten percent (Gottfried, 1983, 68).
} 
Our central claim is that, by increasing the price of labor relative to land, Black Death mortality shaped patterns of labor coercion and the long-term development of local political cultures. Extant studies offer two competing approaches for thinking about the starting point of this argument: the effect of changes in factor prices on labor coercion.

The standard account can be classified as the theory of "Malthusian Exit." According to this view, shocks that generate a high level of labor scarcity (increasing labor's shadow price) catalyze a series of economic and social changes that move a society away from a subsistence economy based on labor coercion to one with manufacturing potential based on free labor (North and Thomas, 1973; Postan, 1966; Voigtländer and Voth, 2013). Specifically, the scarcity of labor improves the outside options of laborers, forcing elites to reduce coercive practices, which in turn creates greater and more variegated forms of consumption. As demand for manufactured goods increases, new technologies develop, urban areas expand, and the power of landed elites begins to wane. This theory is often invoked to explain Western Europe's development in the wake of the Black Death.

An alternative account can be classified as the theory of "Elite Reaction." In this account, elites respond to an increase in the scarcity of labor by doubling down on coercion (cf. Blum, 1957; Brenner, 1976; Domar, 1970). In particular, elites utilize greater amounts of coercion to arrest the wage increases and improvements in living standards that would otherwise follow a reduction in labor force size. The overall system of labor coercion remains in place, with labor obligations and the policing of labor becoming only more burdensome. The agrarian economy remains supreme, technological innovation is suppressed, and the power of landed elites remains uncontested. This is the theory often invoked to explain the recrudescence of serfdom and underdevelopment in Eastern Europe in the wake of the Black Death.

In an important theoretical contribution, Acemoglu and Wolitzky (2011) present a frame- 
work integrating the mechanisms underlying both accounts. The framework's central implication is that the impact of labor scarcity on coercion depends on outside options of laborers versus the price of the landed elites' good. If the outside option effect dominates, then labor coercion will wane. However, if labor scarcity increases the value of the good produced by landed elites to a sufficiently high level, then coercion will become more intense.

Empirical studies that speak to the relative purchase of each theory are limited and offer contradictory findings. ${ }^{5}$ In truth, much of the existing empirical work provides limited guidance for understanding the consequences of a labor market shock like that generated by the Black Death. This is because previous contributions are largely concerned with tracing out the consequences of variation in relative factor prices along the intensive margin, i.e. for small amounts of change within the respective society. The Black Death, by contrast, generated change along the extensive margin. Indeed, at an aggregate level it was one of the largest labor market shocks in recorded human history. As we will argue in the subsequent section, the depth of labor scarcity is important in understanding elite reaction to a labor supply shock. Reactions to minor shocks will not be the same as those to large ones.

The empirical findings of our paper about the long-term legacy of the Black Death contribute to a prominent literature on the economic and political consequences of infectious diseases. The incidence of infectious diseases has been tied to low levels of labor productivity and investment, and ultimately to the emergence of 'poverty traps' in tropical areas (Bonds, Keenan, Rohani and Sachs, 2010; Gallup and Sachs, 2001; Sachs and Warner, 1997). Exposure to disease for populations in utero creates developmental disabilities that reduce levels of educational attainment, an important contributor to economic growth (Almond, 2006). In a long-term perspective, diseases may also determine the composition and behavior of the

\footnotetext{
${ }^{5}$ For instance, the findings of Naidu and Yuchtman (2013) and Klein and Ogilvie (2017) are largely consistent with Elite Reaction theory, whereas those of Dippel, Greif and Trefler (2016) and Ardanaz and Mares (2014) are consistent with the logic of Malthusian Exit theory.
} 
ruling elite. According to Diamond (1998), the immunological advantages conferred upon Europeans by living in proximity to livestock (and suffering through repeated disease waves) partially explain the ease with which they were able to conquer the Americas.

More directly related to the paper at hand, Acemoglu, Johnson and Robinson (2001) argue that the disease environment at the time of colonization determined the types of institutions colonizers implanted in their colonies, thereby shaping the quality of government and prospects for economic development in the long run. Our study can be seen as a natural complement to theirs. Whereas they demonstrate that diseases can affect political development via the external imposition of institutions, we demonstrate that diseases can also catalyze processes of institutional change that are internal to societies.

Our paper is also linked to Sellars and Alix-Garcia (2018), who study how disease-driven demographic collapse in colonial Mexico shaped land tenure patterns. Contrary to the tenor of our findings for the Black Death, the authors find that landed estates in 1900 were more prominent in areas that had previously experienced a population collapse. We attribute the differences in our findings to distinct starting points: Whereas indigenous communities held substantial land in early colonial Mexico, the manorial economy (dominated by landed elites) was more or less a constant in medieval Europe. Given the pre-Black Death land ownership structure encountered in German-speaking Central Europe, it follows that the primary consequence of population decline would be an increase in labor's bargaining power.

In examining how demographic change reshapes social and political organization in agrarian societies, our paper also contributes to the study of landed elite power and its implications for democracy. Historical investigations of political change have long emphasized that the economic and political power of the landed elite tends to delay or preclude the transition to democracy (Moore, 1966; Rueschemeyer, Stephens and Stephens, 1992; Ziblatt, 2008). 
Moreover, for countries that have already made the transition, the presence of a powerful landed elite fundamentally shapes the manner in which elections are contested.

Practices such as clientelism and vote brokerage are held to be especially effective in contexts in which landed elites employ a large segment of the labor force (Anderson, Francois and Kotwal, 2015; Scott, 1972; Stokes, Dunning, Nazareno and Brusco, 2013). Consequently, in agrarian settings with dominant landowners, voters are often induced to vote for the politicians that elites prefer, typically conservative politicians inclined to defend the extant property rights regime (Baland and Robinson, 2008; Gingerich, 2020; Gingerich and Medeiros, 2020; Mares, 2015). Our contribution to this literature is to endogenize the sources of landed elite power in a long-term historical perspective. Specifically, we show how exogenous shocks to the labor supply can undermine the landed elite's political influence. In so doing, we offer a novel account of the historical genesis of programmatic versus clientelistic linkages between citizens and politicians (cf. Kitschelt and Wilkinson, 2007).

\section{The Long-Term Implications of Labor Supply Shocks for Electoral Behavior}

In this section of the paper, we explicate the theoretical mechanisms tying labor supply shocks to long-run electoral behavior. Our starting point is the premise that the magnitude of the initial shock is crucial. Labor supply shocks that are sufficiently profound create a new institutional equilibrium that recasts the relationship between lord and peasant, producing more inclusive modes of political engagement that, in the long run, structure mass political behavior. Labor supply shocks that are weaker lead to a retrenchment of socioeconomic hierarchies and obligations, producing exclusionary modes of political engagement that also structure mass political behavior, albeit in a very different way. 
Consider the relationship between labor supply shocks and labor coercion. If a demographic collapse radically reduces the labor supply, then this has two immediate consequences. First, the shadow price of the coerced worker's labor skyrockets. ${ }^{6}$ The economic returns to work outside the manor to which the laborer is bound become much greater, so the attractiveness of risking punishment by seeking employment elsewhere increases significantly. For the elites, keeping what remains of the labor force in place requires either an increase in wages (and a lessening of customary obligations) or greater investment in the monitoring and punishment of laborers. Given economies of scale in policing labor, the per-laborer cost of dissuading exit through coercion will be exorbitantly high. Thus, unless labor productivity increases immensely as a consequence of the shock, movement towards an incipient free wage regime will be seen by elites as the least detrimental option.

The second consequence of a negative labor supply shock concerns the prospects for coordination among agrarian elites. Given the reality of a decimated labor force, the competition among elites for laborers will be quite intense: Success or failure in poaching the labor of neighboring manors may mean the difference between bringing a crop to harvest or having it rot in the fields. Consequently, to keep wages low and laborers on their manors, elites must expend significant effort in creating and policing an anti-poaching cartel among themselves. The larger the shock, however, the greater the returns to each member of the elite from defecting from the cartel. Thus, for a sufficiently large shock, maintaining the anti-poaching cartel will be next to impossible. An incipient free wage regime emerges by default.

If the shock to the labor supply is relatively minor, then these dynamics will be very different. With only a moderate reduction in the labor force, the returns to laborers from fleeing their manors will be smaller and for elites the per-laborer cost of dissuading exit

\footnotetext{
${ }^{6}$ In England, the Black Death led to an immediate increase of 50 percent in the real wages of farm workers (Campbell, 2016, 310).
} 
through coercion will be much more manageable. Moreover, given the smaller returns to elites from poaching the laborers of their peers, it will be feasible to sustain a cartel. Consequently, whereas large labor supply shocks will prompt an early exit from labor coercion, smaller shocks will be associated with its persistence.

The abandonment or persistence of labor coercion, in turn, has implications for economic, social, and political organization. In settings where labor coercion has diminished, the freedom of movement for laborers contributes to greater urbanization as well as a restructuring of relationships in the countryside. With greater urbanization and higher living standards comes the development of new technologies that jump-start new forms of manufacturing (such as textile production or the production of books based on moveable type). Overall, the weight of agriculture in the economy diminishes. Agricultural production itself shifts away from the classic manorial model where land and property rights are vested solely in elites to one in which land rights become more widely shared. The roots of a system of small farming are established, and formerly gaping inequalities in landownership become more modest. $^{7}$ The improvements in employment opportunities and diversification of property rights naturally lead to a more variegated social structure and a populace characterized by greater heterogeneity of preferences. The new social groups, in turn, demand channels for the representation of their interests. At the local level, this leads to the development of institutions such as the election of mayors and town councils, providing for a (limited form) of self-government. Although traditional elites frequently enjoy initial veto power over such institutions, their very existence encourages non-elite coordination and demand-making (cf. Giuliano and Nunn, 2013). The seeds for autonomous political participation are thus sown.

In settings where labor coercion persists unabated over a long period of time, the afore-

\footnotetext{
${ }^{7}$ See Alfani, Gierok and Schaff (2020) for direct evidence on the reduction in wealth inequality in Germanspeaking Europe following the Black Death. Similar evidence is provided in Alfani (2015) and Alfani and Ammannati (2017) for the Piedmont and Tuscany regions of Italy, respectively.
} 
mentioned occurrences do not come to pass. Peasants remain tied to the land and urban areas are small and few and far between. The adoption of technological innovations, to the extent that these emerge from elsewhere, is actively discouraged by the traditional elites. Land tenure patterns evolve at a glacial pace, if they evolve at all. True political power remains vested in the landed aristocracy, which perpetuates its status through the use of enforcers deployed to police labor. The economy gravitates around agriculture, which in turn is dominated by a small number of large landholdings. Institutions designed to channel the demands of non-elite actors are unlikely to emerge, and if they do, they perish quickly. The great mass of the citizenry gains little or no experience in advocating for their own interests, and most certainly not in a way that might conflict with the desires of the agrarian elite. In this context, the prospects for autonomous political participation are dim.

The divergent paths of labor coercion that emerge in the wake of labor supply shocks create very different environments for the practice of electoral politics once the era of mass politics begins. Areas where labor coercion was dismantled early differ from those where it persisted over time in four crucial ways. First, early reforming areas have more differentiated economies, giving more voters viable employment opportunities outside of their current job. As a consequence, they will not so easily be intimidated by employers who wish to sway their votes one way or another (cf. Frye, Reuter and Szakonyi, 2014; Mares, 2015). Second, the opportunities afforded to laborers in early reforming areas encourage greater human capital development, and in particular, higher levels of education. As a result, voters are more likely to be politically engaged, with greater awareness of what their political options are and a keener sense of how different contenders do or do not reflect their interests (Dee, 2004; Milligan, Moretti and Oreopoulos, 2004; Sondheimer and Green, 2010). Third, because of the legacies of labor coercion for urbanization, voters in early reforming areas are likely 
to be located in more densely populated communities than those in late reforming areas. Greater population density makes it more difficult for traditional elites to monitor and profit from clientelistic exchanges, thereby limiting the influence of material inducements on voting patterns (Brusco, Nazareno and Stokes, 2004; Gingerich and Medina, 2013). Finally, and arguably most important, due to the erosion of traditional socioeconomic hierarchies in early reforming areas, voters in these areas are less likely to adhere to norms dictating deference to elites. Among such norms are norms of reciprocity, which have historically facilitated the ability of local elites to guide the electoral choices of voters (Finan and Schechter, 2012; Lawson and Greene, 2014). Seen more broadly, such deference norms reflect political cultures in which citizens view themselves as the subjects of political and economic elites, a state of affairs conducive to the growth of illiberal political movements (Almond and Verba, 1963; Lewin, 1943).

To summarize, the societal context bequeathed by the early erosion of labor coercion is one where, in the long run, voters (1) have a clear sense of for whom they would prefer to vote; (2) enjoy the economic and cultural autonomy to vote as they wish. In contrast, the societal context bequeathed by the late or incomplete erosion of labor coercion is one where voters ultimately neither have strong preferences over contending political forces nor the wherewithal to resist the voting instructions of traditional elites. Figure 2 summarizes the theory. ${ }^{8}$

\footnotetext{
${ }^{8}$ In the appendix (subsection A.25), we apply this theoretical framework by providing an extended historical discussion of Black Death severity, the evolution of serfdom, and the development of distinctive political traditions across various regions in German-speaking Central Europe. The reader interested in a more comprehensive understanding of how our proposed mechanisms operated over time in specific principalities in the German-speaking lands will find a wealth of detail in that section.
} 
Figure 2: Long-Term Consequences of the Black Death

\begin{tabular}{|c|c|c|}
\hline $\begin{array}{l}\text { High loss of life: } \\
\text { adverse labor supply } \\
\text { shock } \rightarrow \text { labor } \\
\text { coercion dismantled } \\
\text { early }\end{array}$ & $\begin{array}{l}\text { Restructuring of socioeconomic } \\
\text { relations: reductions in land } \\
\text { inequality } \& \text { greater bargaining } \\
\text { power of labor } \rightarrow \text { development of } \\
\text { early participative institutions }\end{array}$ & $\begin{array}{l}\text { Robust experience with } \\
\text { democratic engagement: } \\
\text { voters reject traditional } \\
\text { elites } \rightarrow \text { weak conservative } \\
\& \text { strong liberal parties }\end{array}$ \\
\hline $\begin{array}{l}\text { Low loss of life: } \\
\text { minor change to labor } \\
\text { supply } \rightarrow \text { labor } \\
\text { coercion remains } \\
\text { feasible }\end{array}$ & $\begin{array}{l}\text { Traditional socioeconomic } \\
\text { relations maintained: high land } \\
\text { inequality } \& \text { forms of labor } \\
\text { coercion persist } \rightarrow \text { emergence of } \\
\text { participative institutions unlikely }\end{array}$ & $\begin{array}{c}\text { No experience with } \\
\text { democratic engagement: } \\
\text { voters defer to traditional } \\
\text { elites } \rightarrow \text { strong conserva- } \\
\text { tive \& weak liberal parties }\end{array}$ \\
\hline $\begin{array}{l}\text { Initial Shock } \\
(1347-1351)\end{array}$ & $\begin{array}{c}\text { Early Modern Period } \\
\text { (14/15th-18th Centuries) }\end{array}$ & $\begin{array}{c}\text { Dawn of Mass Politics } \\
\text { (19th/Early 20th Century) }\end{array}$ \\
\hline
\end{tabular}

\section{Background on the Case of Germany}

The subject of our empirical analysis is an area in Central Europe that, in the present-day, is mostly referred to as Germany. For nearly the entire time period under consideration (the fourteenth to nineteenth centuries), however, "Germany" remained politically fragmented. Because of the Holy Roman Empire's status as a confederation - as opposed to a centralized nation-state - Germany can also be understood as a cultural entity, united primarily by a common language and shared customs.

\subsection{Rationale for Case Selection}

There are two primary reasons for concentrating on this geographic area. The first is significant regional variation in the Black Death's intensity. Much of Germany's west, southwest, and parts of the north were subject to devastating outbreaks while many towns and settlements in the easternmost parts were relatively unaffected.

The second reason is Germany's historically high level of political decentralization, allowing local traditions to persist over extensive time periods (Blanning, 2012; Frost, 2012; 
Wilson, 2003). In fact, Germany remained split into hundreds of principalities, city-states, kingdoms, and other administrative units. This combination makes Germany the ideal case for studying the pandemic's long-term effects. While in other countries, such as France and Britain, a central state was able to supplant local institutions, in Germany local political traditions had ample space to survive until at least the late nineteenth century — and possibly beyond.

\subsection{Imperial Germany: Socioeconomic Conditions and Political Outcomes}

In 1871, following the Wars of German Unification (1864-1871), Prussia united most of the German cultural region (excluding Austria) under a single political system known as "Imperial Germany" or the "German Empire." Based on our theory about the social transformation associated with the Black Death, we use this case to investigate long-term variation in both (1) fundamental socioeconomic structures and (2) local political behavior. Since both outcomes reflect aspects of long-term political-economic equilibria affected by Black Death exposure, their combined analysis is of prime importance to our argument.

In terms of socioeconomic structures, we focus on the level of landholding inequality. This feature of society is often deeply rooted in historical events. Where landholding inequality is high, a small number of landholders have a disproportionate share of property in the agricultural sector, indicating that it is more elite-dominated. Such elite domination of rural property rights is often associated with elite domination of politics (Ziblatt, 2008; Ziblatt, 2009). ${ }^{9}$

In terms of political outcomes, we consider voting behavior in elections of the Impe-

\footnotetext{
${ }^{9}$ Since the socioeconomic relevance of land inequality could be affected by the overall economic importance of agriculture, we account for this possibility in an extension to our empirical analysis (subsection A.6).
} 
rial Diet (Reichstag), the lower chamber of the Empire's legislature. Although it was less powerful than many present-day parliaments, its elections generated intense public interest. Importantly, the formal conditions of the elections (electoral rules, voting age, suffrage restrictions) were homogeneous across Germany, making it suitable for a cross-sectional analysis. ${ }^{10}$ Two outcomes are of greatest interest to us: (1) the vote share that the Conservative party received in $1871^{11}$ and (2) the number of electoral disputes between 1871 and 1912, with the latter indicating violations of electoral rules (typically by elites) and being studied extensively by Ziblatt (2009) and Mares and Zhu (2015).

We focus on the Conservative Party of the early 1870s because it was inherently elitist in both means and ends. Its stated goal was to defend traditional social structures, i.e. the privileged position of the landed elites. Moreover, in line with its historical roots, it turned against popular democracy, resisted the socioeconomic changes caused by industrialization, and railed against national unification, as the latter was perceived to threaten the aristocracy (Anderson, 2000, Ch. 6; Berdahl, 1972, esp. 3-4, 18; Berdahl, 1988; Eley, 1986; Retallack, 1988, 13-14; Retallack, 2006). ${ }^{12}$ Although the party ran in formally democratic elections, the landed elites used intimidation, clientelism, and the coerced mobilization of agricultural workers to improve their chances of victory (Anderson, 1993; Anderson, 2000, Ch. 6; Mares, 2015, Ch. 3-5; Nipperdey, 1961, Ch. 5).

As such tactics demonstrate, while formal electoral regulations were the same across Germany, local socioeconomic conditions and political norms varied significantly (Eley, 1986). This diversity also led to variation in the parties that ran across different districts (Sperber,

\footnotetext{
${ }^{10}$ Formally, all males aged 25 or above were allowed to give a direct and secret vote in a majoritarian single-member district electoral system.

${ }^{11}$ In the study's appendix, we also analyze the electoral results of other parties as well as the 1874 election.

${ }^{12}$ This was especially true for 1871 , when the Conservative Party still endorsed an "estate society." Yet the incompatibility of the party's stance with capitalist development led it to give up on this goal, as expressed in the party's reorganization in 1876 as the "German Conservative Party" (Berdahl, 1972, 2-3).
} 
1997, 26, 114). In some districts, parties did not encounter the necessary socioeconomic conditions or political traditions to be viable competitors. ${ }^{13}$ For the Conservative Party, the socioeconomic and political structures associated with high landholding inequality - reflecting an institutional equilibrium that facilitated abuses of power and undermined democratic elections - were a key factor determining its electoral viability (Anderson, 2000, Ch. 6; Lepsius, 1966; Ziblatt, 2008; Ziblatt, 2009). Yet where these conditions did not exist, the Conservative Party had little chance of succeeding in open electoral competition, leading to the absence of an appreciable party organization in those locations. ${ }^{14}$

Considering the relationship of deeply-rooted political norms and socioeconomic circumstances with electoral outcomes is in line with previous scholarly work. Most importantly, Lepsius (1966) argues that parties in nineteenth-century Germany reflected "sociomoral milieus," which were themselves based in deeply rooted factors, such as culture, socioeconomic conditions, and political norms (Hübinger, 2008; Sperber, 1997, 3). ${ }^{15}$ Importantly, this variation predated industrial society and the Empire's political system (Sperber, 1997, 4-5).

We initially focus on electoral outcomes in 1871 because, with national unification just beginning at that time, local political traditions are most likely to be strongly visible in the recorded electoral behavior of this period. However, in the following section, we also consider the Weimar Republic's crucial 1930 and 1932 elections. These additional analyses are meant to explore if the political-economic equilibria created by differential exposure to

\footnotetext{
${ }^{13}$ This is likely one of the reasons for why the Conservative Party chose to not nominate candidates in many more urban settings (cf. Nipperdey, 1961, 247).

${ }^{14}$ Across Imperial Germany, the Conservative Party had at least one candidate in 46 out of 67 government districts (Regierungsbezirk). Government districts are higher-level aggregate units that encompass multiple electoral districts. While these numbers show that the party was theoretically capable of running in a large cross section of Imperial Germany, its practical electoral viability was severely limited in certain parts of the country. In only 27 government districts did it receive an average of more than $10 \%$ of the vote. Due to the aforementioned divergence in socioeconomic conditions and political traditions, it was also often unable to field candidates in all electoral districts of any given government district. These circumstances highlight the spatial distinction in political-economic equilbria that was historically caused by the Black Death.

${ }^{15}$ Variations in local culture and norms can persist over long time periods and shape political-economic outcomes (Acharya, Blackwell and Sen, 2018; Alesina and Giuliano, 2015; Vogler, 2019).
} 
the Black Death persisted into interwar Germany. Furthermore, to ensure that our initial results are not merely driven by Prussia's military victory in 1871 or other idiosyncratic factors related to any specific election, we also consider the results of the 1874 election in the study's appendix.

\subsection{Weimar Germany: Persistence of Local Political Cultures and Votes for the National Socialist Party}

Given our contention that differing levels of exposure to the Black Death bequethed distinctive and enduring political traditions that contributed to the electoral viability of illiberal parties, it is worthwhile to investigate if the divergence caused by the Black Death is still visible in later elections, especially the fateful German elections of 1930 and July 1932. Because these elections ultimately gave rise to National Socialism as a major force in German politics - and thus represent the precursor to the barbaric crimes committed, the wars initiated, and the exploitation conducted by the Nazi regime (Mazower, 2009; Rich, 1992) — their relevance for the course of world history is unquestionable .

Specifically, in 1930, the NSDAP was able to increase its vote share from $2.6 \%$ to $18.3 \%$, increasing the numbers of seats almost ten-fold, from 12 to 107 . Therefore, this election is considered to have been a "breakthrough election" for the National Socialists (O'Loughlin, 2002, 220-224). Moreover, in the July 1932 election, the NSDAP became the parliament's largest party with slightly more than 37\% of the vote (O'Loughlin, 2002, 220-221).

At first glance, a number of factors cast doubt on the proposition that the changes brought by the Black Death would still be visible in the Weimar Republic. For one, after the 1870s, politics in Germany became more nationalized, impacting social attitudes and ultimately leading to the development of a national democratic culture (Anderson, 1993, 2000). This development may have entailed a move away from the highly decentralized initial conditions. 
Additionally, after 1871, the second wave of industrialization took off in Germany and led to comprehensive social transformation (Hahn, 2011; Sperber, 1997, 5; Streb, Baten and Yin, 2006). The consequences included the rise of Social Democracy and a realignment of the party system (Berman, 2001, esp. 441-442, 445-446; Sperber, 1997, esp. 7). In particular, the year 1890 is viewed as the turning point from more elite-centered politics to more popular politics (Sperber, 1997, 19). ${ }^{16}$

This combination of national trends likely decreased the influence of regional political traditions derived from experiences with the Black Death. ${ }^{17}$ It is also the reason for why we initially focus on the early 1870 s election. ${ }^{18}$ Yet if the political cultures shaped by differences in Black Death intensity had been able to survive for more than five hundred years, the remnants of these political cultures may still have been visible in the Weimar period (1918-1933) (Lepsius, 1966).

Indeed, several studies suggest that, similar to Imperial Germany, Weimar Germany retained a geographically fragmented electoral landscape, with election outcomes - including voting patterns for the NSDAP — often strongly influenced by local socioeconomic configurations, culture, and traditions (Ault and Brustein, 1998; Flint, 1998, 2000; Frøland, Jakobsen and Osa, 2019; O'Loughlin, 2002; O’Loughlin, Flint and Anselin, 1994). If local conditions and traditions greatly differed across space, the Nazis' potential for electoral success likely varied accordingly. ${ }^{19}$

\footnotetext{
${ }^{16}$ For instance, as of 1890 all major parties began to become more active in rural areas that had previously been dominated by the landed elites (Eley, 1986).

${ }^{17}$ Moreover, World War I not only brought death at a massive scale, but also further socioeconomic changes, such as the integration of women into the labor force.

${ }^{18}$ In terms of electoral disputes, we investigate a longer period as detailed in the next section.

${ }^{19}$ For instance, Satyanath, Voigtländer and Voth (2017) show that differences in social capital across towns predicts entry into the Nazi party, which, in turn, predicts the party's electoral success. Additionally, Thurner, Klima and Küchenhoff (2015) suggest that agricultural economic structure was a key factor in determining the NSDAP's electoral outcomes. Anheier (2003) finds that pre-existing right-wing social networks amplified the NSDAP's political mobilization efforts. A similar argument is made by Berman (1997). Finally, Brustein (1996) and King, Rosen, Tanner and Wagner (2008) argue that economic conditions and incentives likely played an important role in shaping voting behavior of Weimar citizens. All of these factors
} 
Thus, despite the aforementioned national trends, the regional political traditions generated by differential exposure to the Black Death may still have affected electoral outcomes in the Weimar Republic. Specifically, O'Loughlin $(2002,232)$ suggests that a possible interpretation of spatial differences in the Nazi party's success is the following:

Weimar Germany was simply a complex mosaic of culturally identifiable microregions, a product of history of local principalities, weak central authority, and intense political-confessional competition.

There are several reasons for why we would expect the Nazi party to perform well in areas that do not have a long history of social equity and self-goverment. Most importantly, the Nazi party promoted a modernized variation - and in many ways an even more extreme and aggressive version - of the hierarchical and strongly illiberal political views that had been championed by the Conservative Party in the early 1870s. ${ }^{20}$ Accordingly, if there were still remnants of the regional political cultures created by the Black Death, then we should observe that the National Socialist Party performed best in those areas of Germany that developed cultures of deference due to being spared from the most severe Black Death outbreaks.

\section{Empirical Design}

In this section, we describe the construction of our main independent variable, additional data we employ, and the specifications utilized in our empirical analysis.

varied widely across Germany's regions, with their configuration shaped by historical patterns.

${ }^{20}$ Of course, there were also important differences between these two parties. Among others, National Socialist ideology put significantly more emphasis on nationalism, anti-semitism, and racism than the landed elite-centered Conservative Party of the 1870s. 


\subsection{Measuring the Intensity of the Plague: The Black Death Ex- posure Intensity (BDEI) Score}

Since (1) the Black Death's impact varied widely across Central Europe and (2) its intensity represents our key explanatory variable, the construction of an appropriate measurement is of prime importance. To this end, we use data by Jedwab, Johnson and Koyama (2019a) on recorded outbreaks in European towns, which itself is primarily based on Christakos et al. (2005), to compute a measure of "Black Death Exposure Intensity" (the BDEI score).

While we have data on mortality rates for a number of individual medieval towns that we use to assess the Black Death's impact, our score is not simply a reflection of how intense the outbreak was in the nearest town only. Instead, it is a composite measurement, accounting for the extent to which the area around any specific location was affected. The key substantive reason for computing the score in this manner is as follows. Labor is a highly mobile factor of production. Accordingly, if the Black Death only has a minor impact or only hits a small number of locations in an area, labor supply can return to an old equilibrium more quickly due to regional market forces (cf. Hilton, 1969, 32). ${ }^{21}$ But if many locations in an area are severely hit by an adverse shock at the same time, then returning to a previous equilibrium is much more difficult, even with a mobile production factor like labor.

Mathematically, the BDEI score represents the sum of recorded outbreak intensities inversely weighted by the distance to any specific location. The weighting is inverse (and exponentially decreasing) because outbreaks in the closest vicinity are most relevant. ${ }^{22}$

\footnotetext{
${ }^{21}$ On high labor mobility in the wake of the Black Death, see also Bergdolt (2006).

${ }^{22}$ It is important to acknowledge that the underlying data we use to compute this score is imperfect as it simply does not cover every single European town. Nevertheless, the data's geographic distribution is in line with knowledge on the plague's historical spread and they represent the best and most fine-grained measures currently available. Thus, our score provides a reasonable approximation to the Black Death's historical intensity at any given location. As a robustness check, we provide results based on two alternative datasets of outbreaks in the appendix (subsection A.11).
} 


\subsection{Imperial Germany: Outcome Variables}

The analysis of outcomes in Imperial Germany is at the level of the electoral district. Based on our theory and the specific empirical case, we consider three main outcome variables that reflect distinct political-economic equilibria:

\section{Socioeconomic Conditions}

1. Landholding inequality (Gini coefficient): Data on landholding inequality are provided by Ziblatt (2009), who uses the Gini coefficient to compute a score between 0 (absolute equality) and 1 (absolute inequality). ${ }^{23}$

\section{Political Outcomes}

2. Conservative Party vote share (1871): Data on electoral outcomes are provided by Sperber (1997). These data reflect the Conservative Party's vote share in the 1871 elections.

3. Net electoral disputes (1871-1912): Data on electoral disputes are by Arsenschek and Ziblatt (2008). ${ }^{24}$ These data reflect the cumulative number of disputes that occurred in all peacetime elections. ${ }^{25}$

\subsection{Imperial Germany: Control Variables}

Controlling for factors that could affect both historical Black Death intensity and subsequent long-run political-economic outcomes is crucial. While the electoral districts of the Imperial Diet were a novel unit of organization (only going back to the census of 1864) for which there were no prior unit-specific historical data collected, several geographic features as well

\footnotetext{
${ }^{23}$ Furthermore, in the appendix (subsection A.6), we provide results on the determinants of landholding inequality limited to contexts in which the agricultural workforce is large relative to the total workforce. See Mares (2015, 23-24, Ch. 4) for a directly related argument. Data on the agricultural workforce are by Reibel (2007), with Ziblatt (2009) offering a digitized version.

${ }^{24}$ Note that Ziblatt (2009) considers landholding inequality the key explanatory factor when it comes to electoral disputes. By contrast, we consider both outcomes to be part of long run political-economic equilibria that result from variation in Black Death intensity.

${ }^{25}$ The primary reason why we use the entire span of the existence of Imperial Germany is that this is a count variable. If we restrict the analysis to an individual year (such as 1871), we observe zero inflation.
} 
as historical levels of urban density are taken into account in our analysis. Our geographic controls in particular reflect the importance of trade in disease transmission: The Black Death spread through rats often transported by merchants and commercial ships. ${ }^{26}$

Specifically, our control variables are the following:

1. Urban density in 1300: Historical levels of urban density could influence both Black Death intensity and long-term political-economic outcomes. We use data by Wahl (2019) to compute a historical urban density score for each electoral district. ${ }^{27}$

2. Distance to the nearest major port: Not only did the Black Death spread through trade, closeness to major ports could also influence commerce and economic activity in the long run (Benedictow, 2004, 186).

3. Distance to the nearest medieval trade city: For similar reasons as above, we also include distance to the nearest medieval trade city (Hribar, 2016). ${ }^{28}$

4. Distance to the ocean: While major ports were the primary centers of sea trade, there may have been a number of minor ports. Therefore, we include distance to the ocean (the North Sea or the Baltic Sea) as a proxy.

5. Distance to the nearest large river: Much trade took place on large, navigable rivers, likely spreading the plague (Benedictow, 2004, 202). Therefore, we include distance to the nearest large river (European Environment Agency, 2020).

6. Elevation: Elevation could affect the accessibility of population centers to outsiders and animals carrying the plague (Bossak and Welford, 2016, 72), influencing both plague intensity and long-term political-economic outcomes.

\subsection{Weimar Germany: Persistence of Local Political Cultures and Votes for the National Socialist Party}

As an extension to our empirical analysis, we consider the spatial association between Black Death exposure intensities and the vote share for the National Socialist Workers' Party of Germany (NSDAP) in the elections of Weimar Germany.

\footnotetext{
${ }^{26}$ All geographic measures were computed in ArcGis or in R using data by GeoNames (2020).

${ }^{27}$ Similar to the BDEI score's construction, this measure reflects the sum of towns' population sizes (log) inversely weighted by their distance to the electoral district under consideration.

${ }^{28}$ See Wahl (2016a) for a detailed examination of the long-run influence of trade on economic development.
} 
Specifically, we consider two primary outcome variables:

1. NSDAP vote share (1930): For the 1930 election, data on electoral outcomes at the level of the town ${ }^{29}$ and city are provided by Falter and Hänisch (1990).

2. NSDAP vote share (Jul. 1932): For the election of July 1932, data on electoral outcomes at the level of county are provided by Falter and Hänisch (1990).

We use the same set of control variables as in our main analysis. The geographic data to compute them are obtained from Selb and Munzert (2018). ${ }^{30}$

\subsection{Mechanisms, Part I: Pre-Reformation Germany — Introduc- tion of Participative Elections (1300-1500)}

In addition to our primary analysis, we add a secondary set of empirical tests focused on changes in participative institutions at the town level between 1300 to 1500 . These analyses are meant to evaluate empirical support for the political transmission mechanisms outlined in our theory.

Here, we focus on a binary dependent variable based on data compiled by Wahl (2016b): introduction of participative elections (1300-1500). This variable is equal to 1 for towns that newly adopted local participative elections during the 1300-1500 period; 0 otherwise. ${ }^{31}$ Note that "participative elections" in medieval Germany did not refer to a participatory democracy with full voting rights for all adults. Instead, such elections consisted of contests for the mayor, town council or other local offices, usually with participation limited to adult male property owners. That said, even these forms of "moderate" participation are still

\footnotetext{
${ }^{29}$ The dataset provides detailed electoral information for all towns with more than 2,000 inhabitants.

${ }^{30}$ Moreover, in the study's appendix, we provide an alternative empirical analysis based on the less comprehensive and less fine-grained data by O'Loughlin and colleagues (O'Loughlin, 2000; O'Loughlin, 2002; O'Loughlin, Flint and Anselin, 1994).

${ }^{31}$ No towns with participative elections in 1300 discontinued these in 1500. Regardless of whether we include these towns, our substantive findings do not change.
} 
indicative of important changes in political institutions and norms. ${ }^{32}$

Because our unit of analysis here is the town - an organizational unit that existed long before and after the time period that we investigate - additional control variables are available for different points in time for several units. Thus, we account for several socioeconomic and geographic factors that could have an impact on early democratic development.

Specifically, we include variables for (1) elevation, (2) distance to the nearest river, (3) roman road in vicinity, (4) agricultural suitability, (5) population in 1300 (log), (6) ruggedness, (7) urban potential (1300), (8) trade city (1300), and (9) proto-industrial city (1300). We draw these variables from Wahl (2019), which provides detail on coding procedures.

\subsection{Mechanisms, Part II: Early Nineteenth-Century Prussia - The Black Death and the Footprints of Serfdom}

In addition to the pre-1500 analysis focused on changes in political institutions, we evaluate if our proposed mechanisms are consistent with observed differences in socioeconomic structures across regions afflicted with greater or lesser amounts of Black Death mortality. Our theoretical framework emphasizes that serfdom as a socioeconomic institution should have waned in those areas severely affected by the Black Death, whereas it should have grown in strength in those areas largely spared from it. We provide a wealth of qualitative evidence in favor of this proposition in the appendix (subsection A.25), which draws on the voluminous historiography on agrarian organization in western versus eastern German-speaking Central Europe during the medieval and early modern periods. In order to complement this discussion of the link between the Black Death and changes in serfdom, here we also empirically assess the degree to which Black Death mortality is associated with two key empirical footprints of serfdom visible in early nineteenth-century Prussia: the dominance of large estates

\footnotetext{
${ }^{32}$ Further details on the underlying data and coding are provided by Wahl (2016b).
} 
in agriculture and the prevalence of agricultural servants. These measures were compiled by the Prussian state as part of the first available dataset measuring socioeconomic characteristics in a standardized and comparable fashion across large parts of German-speaking Central Europe. ${ }^{33}$

Specifically, we analyze the spatial association between historical Black Death intensities and the following two outcome variables:

1. Large estates as a proportion of all agricultural properties (1816): Data on the number of different types of farms are provided by Becker, Cinnirella, Hornung and Woessmann (2014). Using these data, we compute the proportion of farms in the largest category recorded by the Prussian census, which is "over 300 Prussian morgen." ${ }^{34}$ As we describe in the appendix (subsection A.25), the coercive imposition of onerous labor obligations in the German-speaking lands went hand-in-hand with the consolidation of large, export-oriented estates. Thus, we expect Black Death exposure intensity to be negatively associated with this measure.

2. Agricultural servants as a proportion of the overall population (1816/1819): These data record the proportion of agricultural servants in the overall population, which is arguably an even more direct measure of the legacy of serfdom. Although agricultural servants and serfs are not one and the same (since serfdom was formally abolished in Prussia in 1807), in practice most freed serfs continued to work their lords' lands as renters and wage laborers. Thus, the number of agricultural servants likely represents a good proxy for the former population of serfs. Due to limitations on data availability, the number of servants is from the year 1819 and the population numbers are from the year 1816. As above, we expect Black Death exposure intensity to be negatively associated with this measure.

We use the same set of control variables as in our main analysis. The geographic data on the location of Prussian counties were provided by the Ifo Institute for Economic Research (ifo Zentrum für Bildungsökonomik). ${ }^{35}$

\footnotetext{
${ }^{33}$ The data were collected in the early nineteenth century because, following the Napoleonic Wars, Prussia acquired large parts of west German territories and integrated them into its own administrative structures.

${ }^{34} \mathrm{~A}$ Prussian morgen is approximately 0.3 hectares in size.

${ }^{35}$ Because our data are from different years, we merge data according to the merging keys provided by Becker et al. (2014).
} 


\subsection{Empirical Specifications}

We use a range of outcome variables with different properties and adjust our models accordingly. With respect to land inequality and Conservative Party vote share, we primarily use OLS regression with clustered standard errors. ${ }^{36}$ Similarly, we also use OLS regression when analyzing a number of variables in our extensions and mechanism sections. ${ }^{37}$ For all outcome variables that are truncated, i.e. that have an upper and/or lower limit in their value, we also provide an alternative set of results using Tobit models in the appendix.

The format of our OLS regressions is the following:

$$
y_{i}=\beta_{0}+\beta_{1} \text { BDEI } \text { Score }_{i}+\mathbf{x}_{\mathbf{i}}^{\prime} \boldsymbol{\beta}+\varepsilon_{\mathbf{i}}
$$

where $y_{i}$ is the respective outcome and $\mathbf{x}_{\mathbf{i}}$ represents a vector of covariates at the electoral district level $(i)$. $\beta_{1}$ represents the coefficient of the BDEI score.

We depart from OLS when doing so is called for based on the nature of our outcome variables. When considering net electoral disputes, which is a count variable, we use quasiPoisson models. Moreover, we use logistic regression when analyzing the binary variable introduction of participative elections (1300-1500).

The BDEI score is computed in the following way:

$$
\text { Raw BDEI Score } e_{i}=\sum_{j=1}^{n} L M R_{j} *\left(1-D I S T_{j i}\right)^{k}
$$

where $L M R_{j} \in(0,1]$ is the local mortality rate at outbreak site $j$ and $D I S T_{j i} \in(0,1]$ is the distance between $i$ and $j$, which is used as the weight (with locations farther away from

\footnotetext{
${ }^{36}$ Errors are clustered at the level of the government district (Regierungsbezirk).

${ }^{37}$ In our major extension regarding NSDAP vote shares in Weimar Germany, we cluster errors at the level of the electoral district (Wahlkreis).
} 
$i$ being weighted down). ${ }^{38}$ The parameter $k \in\{3,6,9,12,15\}$ for versions 1 through 5 of BDEI, respectively, represents the distance discount factor. We compute different versions of the BDEI score to demonstrate that results are not dependent on any single value of $k .^{39}$ The further an outbreak site is from the location under consideration $i$, the more it is exponentially discounted. In order to make the different versions of the raw BDEI score more comparable and our results easier to interpret, we standardize them to have a mean of $\mu=0$ and a standard deviation of $\sigma=1$.

\section{Results}

\subsection{Imperial Germany: Socioeconomic Conditions and Political Outcomes}

The results of our empirical analysis reveal a strong relationship between the Black Death's historical intensity and long-term outcomes in Imperial Germany. We begin by considering a graphical overview of landholding inequality across Germany's electoral districts as provided in Figure 3. ${ }^{40}$ The towns with recorded outbreaks are displayed as circles and the outbreaks' intensity is visible in the circles' color. The northeastern districts in particular exhibit high levels of landholding inequality. Additionally, almost all electoral districts in the easternmost parts, where the plague was least severe, have above-average levels of landholding inequality.

As discussed earlier, we also expect a long-term impact of variation in Black Death intensity on Conservative Party vote share, with high vote shares indicating the political-economic

\footnotetext{
${ }^{38}$ For example, consider the individual electoral district $i$. When computing the BDEI score for this district, we calculate the distances to all known outbreak sites $j$ and then use distances according to the above formula to assign weights to the observed local mortality rates $(L M R)$. In this calculation, the upper bound of 1 for the distance parameter $D I S T_{j i}$ represents the maximum distance in the universe of cases under consideration, i.e. the maximum distance between any district $i$ and any recorded outbreak site $j$.

${ }^{39}$ Further, in the appendix we also manually limit the regions based on which the BDEI score is calculated.

${ }^{40}$ These maps are based on data by Nüssli and Nüssli (2008b), Jedwab, Johnson and Koyama (2019a), Sperber (1997), and Ziblatt (2009).
} 
Figure 3: Landholding Inequality by Electoral District

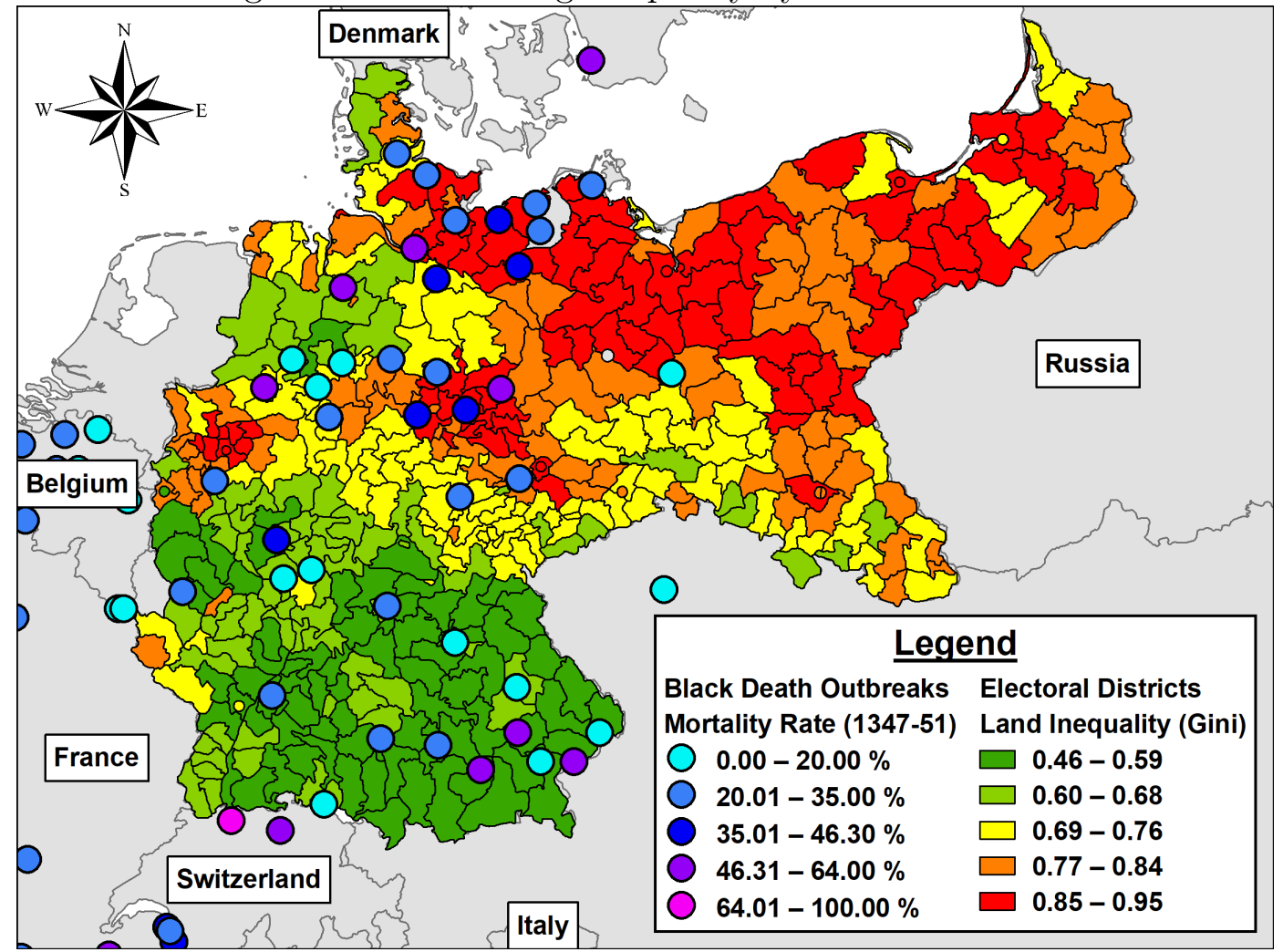

equilibrium linked to high landholding inequality. This is clearly reflected in Figure 4. The party's vote share is systematically higher in areas with fewer and less intense recorded outbreaks. Importantly, as indicated earlier, in many places socioeconomic conditions (and associated political cultures) were such that the Conservative Party did not have a realistic chance to succeed in open electoral competition, as reflected by the absence of an appreciable local party organization and/or minimal vote shares. 
Figure 4: Conservative Party Vote Share (1871) by Electoral District

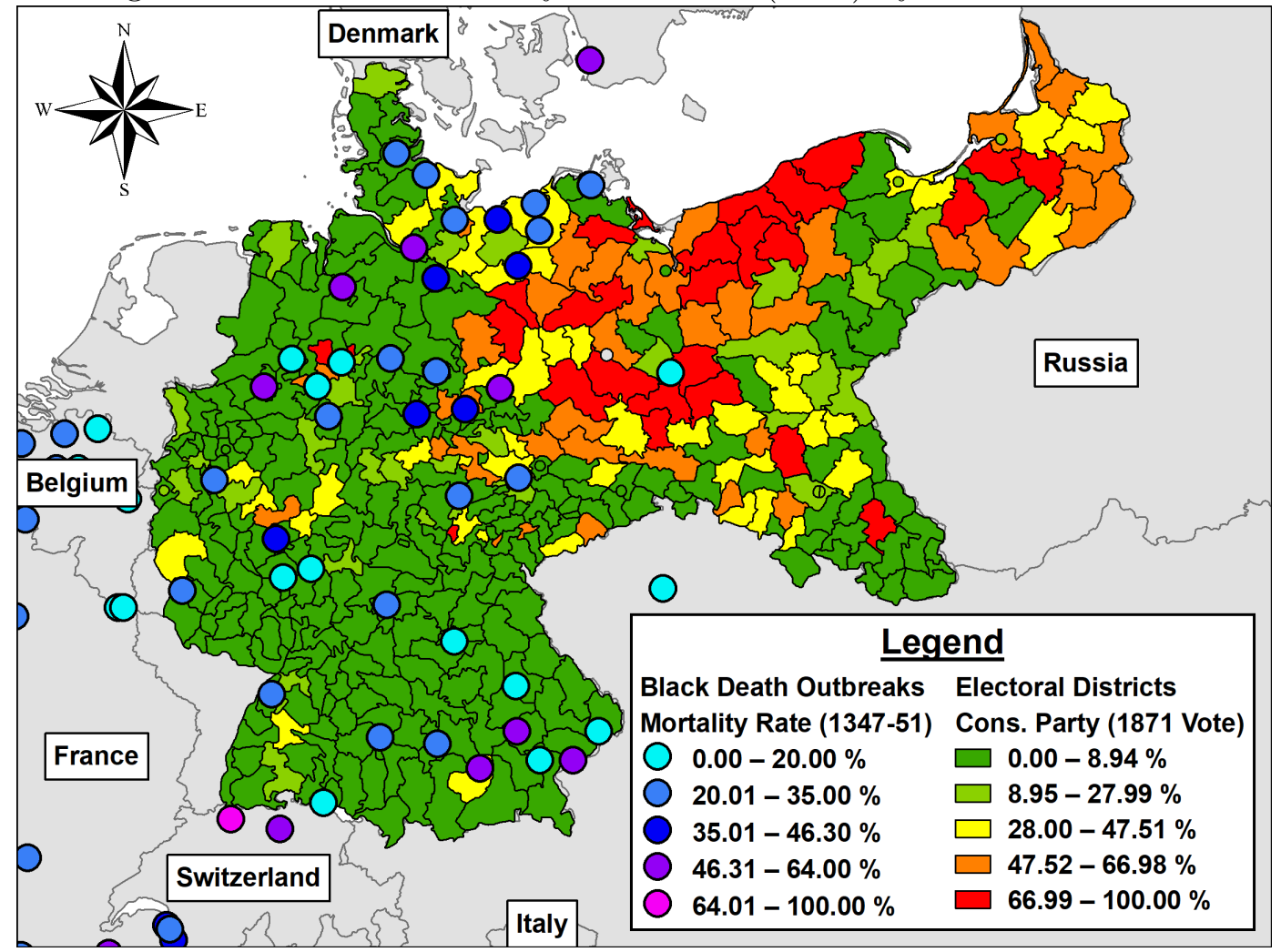

Next we turn to our regression analysis. Table 1 shows our findings with respect to landholding inequality. In addition to a first set of models (1-5) that are based on our key independent variable only, we provide a second set of models (6-10) that include the previously discussed controls. Across all specifications, the BDEI score has a significant negative impact on land inequality, indicating the Black Death's persistent influence on socioeconomic conditions. Specifically, a one standard deviation increase in the BDEI score results in a decrease in landholding inequality (Gini) that ranges from 0.042 to 0.061 (0.350 to 0.508 standard deviations). Figure 5 shows the predicted values for different magnitudes of BDEI score v1.

Table 2 shows the results with respect to Conservative Party vote share. As with the previous analysis, we also provide models without (1-5) and with (6-10) control variables. In line with our theory, the Conservative Party is weaker in areas that had more severe Black 
Death outbreaks, indicated by a high BDEI score. Specifically, a one standard deviation increase in the BDEI score leads to a reduction in the party's vote share ranging from 0.106 (10.6\%) to 0.141 (14.1\%) (0.426 to 0.566 standard deviations). The results are comparable to the above findings, highlighting the pandemic's long-term influence. Figure 6 shows the predicted values for different magnitudes of BDEI score $v 1{ }^{41}$

Finally, Table 3 shows the results of quasi-Poisson regressions on electoral disputes. Here we also find a result in line with our theoretical expectations: In places with more intense outbreaks, one encounters significantly fewer electoral disputes. Specifically, a one standard deviation increase in the $B D E I$ score leads to a change in the logs of expected counts ranging from -0.172 to -0.313 .

In short, we find comprehensive evidence that the Black Death shaped socioeconomic structures and local political behavior in the long run. Both in terms of landholding inequality and the Conservative Party's electoral viability, we find that regional variation in the intensity of plague outbreaks in the fourteenth century has strong predictive power for outcomes in the nineteenth century. These results indicate that this historical shock fundamentally reshaped society in areas where it hit hardest, while it did not alter (or even reinforced) socioeconomic and political hierarchies in other regions, leading to distinct institutional equilibria that persisted for generations. As discussed in more detail below and in the extensions located in the appendix, we find that our results are robust across a large set of alternative approaches to measurement and statistical analysis.

\footnotetext{
${ }^{41}$ With respect to both landholding inequality and Conservative Party vote shares, additional Tobit models are in the appendix (subsection A.2).
} 
Figure 5: Predicted Values Plot: BDEI Score v1 and Landholding Inequality (Gini)

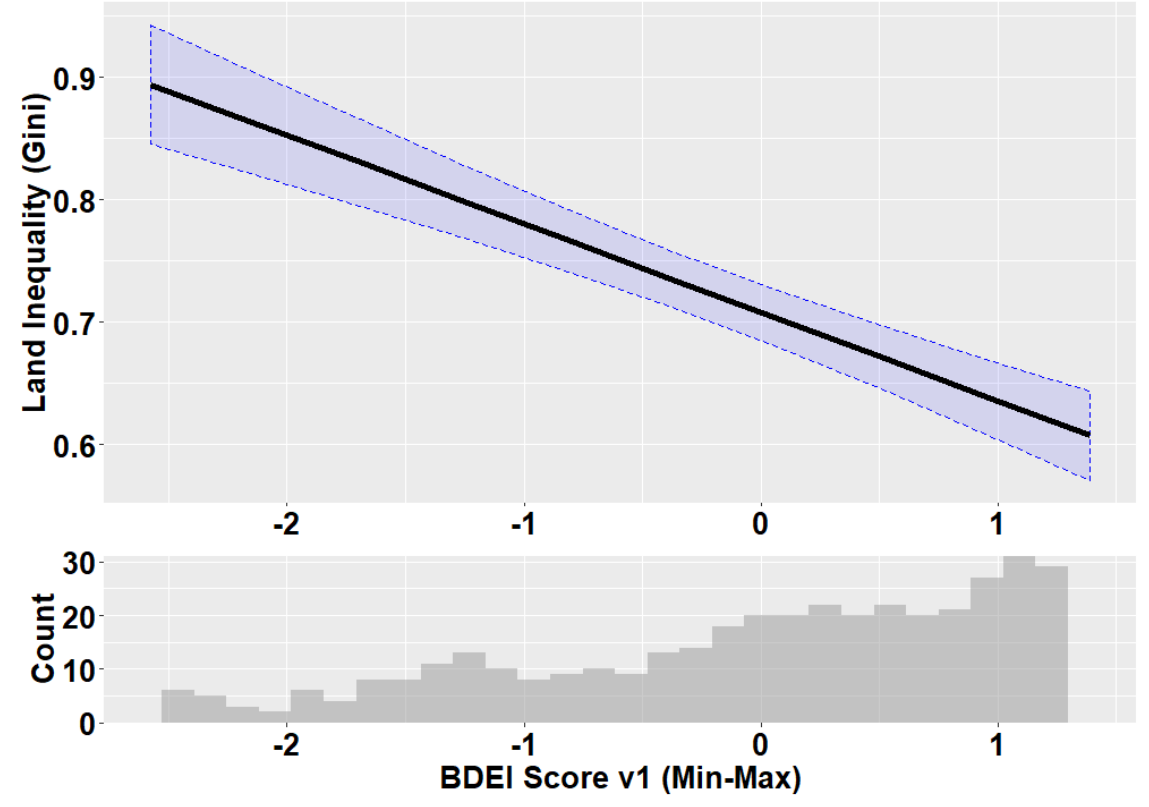

Figure 6: Predicted Values Plot: BDEI Score v1 and Conservative Party Vote Share (1871)

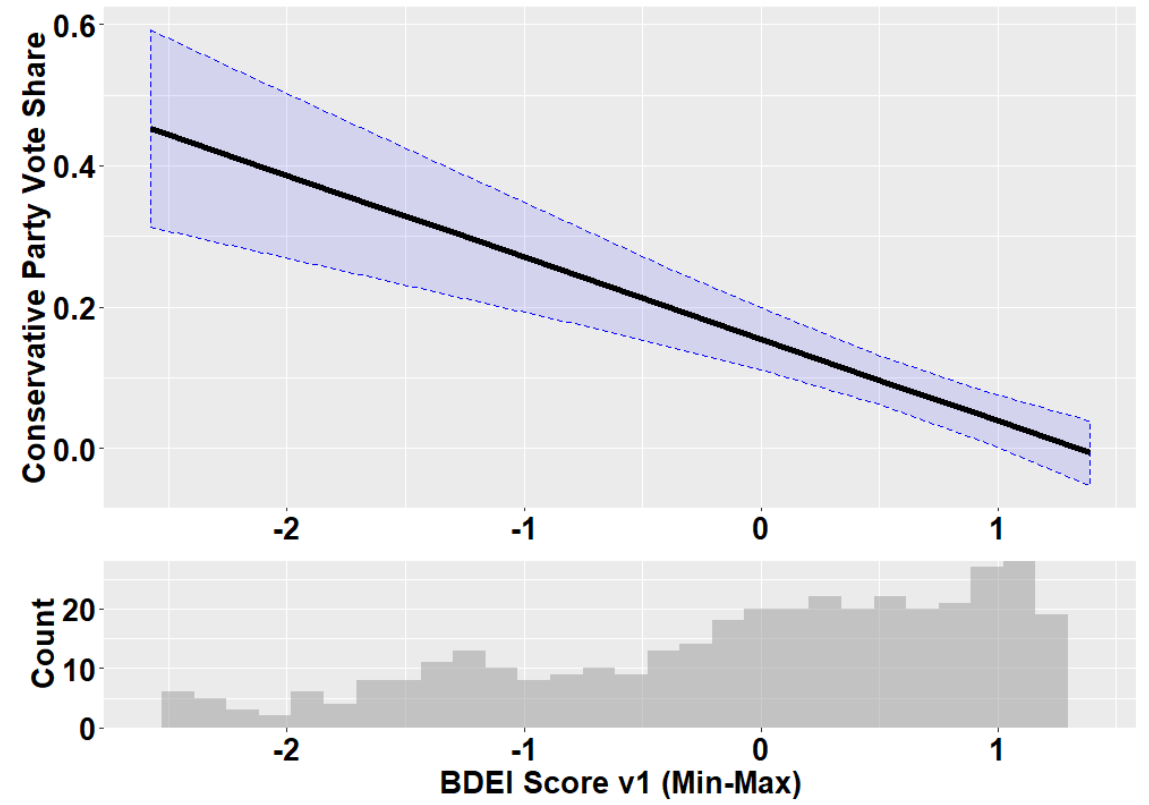


Table 1: Landholding Inequality (OLS)

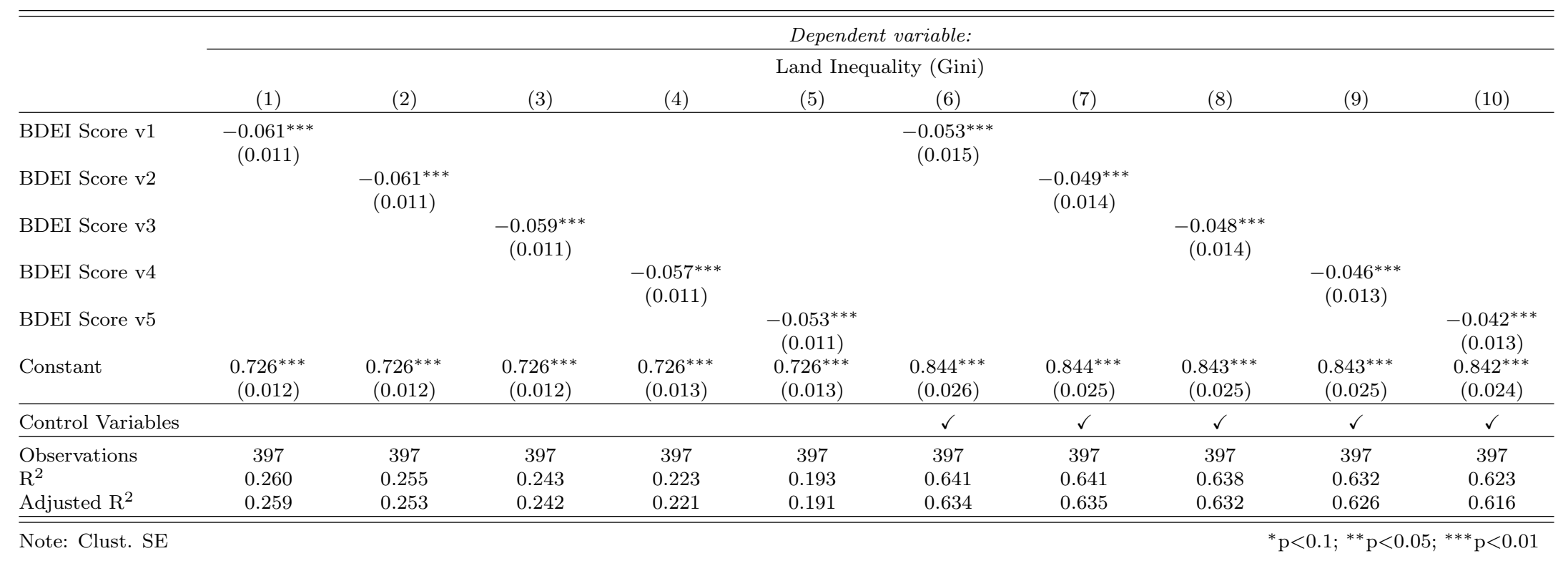


Table 2: Conservative Party Vote Share (OLS)

\begin{tabular}{|c|c|c|c|c|c|c|c|c|c|c|}
\hline & \multicolumn{10}{|c|}{ Dependent variable: } \\
\hline & \multicolumn{10}{|c|}{ Conservative Party Vote Share } \\
\hline & $(1)$ & $(2)$ & $(3)$ & $(4)$ & $(5)$ & $(6)$ & $(7)$ & $(8)$ & $(9)$ & $(10)$ \\
\hline BDEI Score v1 & $\begin{array}{c}-0.116^{* * *} \\
(0.021)\end{array}$ & & & & & $\begin{array}{c}-0.141^{* * *} \\
(0.035)\end{array}$ & & & & \\
\hline BDEI Score v2 & & $\begin{array}{c}-0.115^{* * *} \\
(0.022)\end{array}$ & & & & & $\begin{array}{c}-0.132^{* * *} \\
(0.032)\end{array}$ & & & \\
\hline BDEI Score v3 & & & $\begin{array}{c}-0.113^{* * *} \\
(0.023)\end{array}$ & & & & & $\begin{array}{c}-0.130^{* * *} \\
(0.031)\end{array}$ & & \\
\hline BDEI Score v4 & & & & $\begin{array}{c}-0.110^{* * *} \\
(0.023)\end{array}$ & & & & & $\begin{array}{c}-0.133^{* * *} \\
(0.033)\end{array}$ & \\
\hline BDEI Score v5 & & & & & $\begin{array}{c}-0.106^{* * *} \\
(0.024)\end{array}$ & & & & & $\begin{array}{c}-0.136^{* * *} \\
\quad(0.035)\end{array}$ \\
\hline Constant & $\begin{array}{c}0.155^{* * *} \\
(0.023)\end{array}$ & $\begin{array}{c}0.154^{* * *} \\
(0.023)\end{array}$ & $\begin{array}{c}0.155^{* * *} \\
(0.023) \\
\end{array}$ & $\begin{array}{c}0.155^{* * *} \\
(0.023)\end{array}$ & $\begin{array}{c}0.156^{* * *} \\
(0.024)\end{array}$ & $\begin{array}{c}0.208^{* * *} \\
(0.065)\end{array}$ & $\begin{array}{c}0.206^{* * *} \\
(0.064)\end{array}$ & $\begin{array}{c}0.207^{* * *} \\
(0.063)\end{array}$ & $\begin{array}{c}0.211^{* * *} \\
(0.062)\end{array}$ & $\begin{array}{c}0.216^{* * *} \\
(0.060) \\
\end{array}$ \\
\hline Control Variables & & & & & & $\checkmark$ & $\checkmark$ & $\checkmark$ & $\checkmark$ & $\checkmark$ \\
\hline Observations & 382 & 382 & 382 & 382 & 382 & 382 & 382 & 382 & 382 & 382 \\
\hline $\mathrm{R}^{2}$ & 0.212 & 0.208 & 0.202 & 0.193 & 0.180 & 0.318 & 0.319 & 0.318 & 0.318 & 0.315 \\
\hline Adjusted $\mathrm{R}^{2}$ & 0.210 & 0.206 & 0.200 & 0.191 & 0.178 & 0.305 & 0.306 & 0.306 & 0.305 & 0.302 \\
\hline
\end{tabular}


Table 3: Net Electoral Disputes (Quasi-Poisson)

\begin{tabular}{|c|c|c|c|c|c|c|c|c|c|c|}
\hline & \multicolumn{10}{|c|}{ Dependent variable: } \\
\hline & \multicolumn{10}{|c|}{ Net Electoral Disputes } \\
\hline & $(1)$ & $(2)$ & $(3)$ & $(4)$ & $(5)$ & $(6)$ & $(7)$ & $(8)$ & $(9)$ & $(10)$ \\
\hline BDEI Score v1 & $\begin{array}{c}-0.200^{* * *} \\
(0.051)\end{array}$ & & & & & $\begin{array}{c}-0.313^{* *} \\
(0.135)\end{array}$ & & & & \\
\hline BDEI Score v2 & & $\begin{array}{c}-0.200^{* * *} \\
(0.055)\end{array}$ & & & & & $\begin{array}{c}-0.287^{* *} \\
(0.125)\end{array}$ & & & \\
\hline BDEI Score v3 & & & $\begin{array}{c}-0.196^{* * *} \\
(0.056)\end{array}$ & & & & & $\begin{array}{c}-0.284^{* *} \\
(0.123)\end{array}$ & & \\
\hline BDEI Score v4 & & & & $\begin{array}{c}-0.186^{* * *} \\
(0.057)\end{array}$ & & & & & $\begin{array}{c}-0.291^{* *} \\
(0.125)\end{array}$ & \\
\hline BDEI Score v5 & & & & & $\begin{array}{c}-0.172^{* * *} \\
(0.058)\end{array}$ & & & & & $\begin{array}{c}-0.294^{* *} \\
(0.128)\end{array}$ \\
\hline Constant & $\begin{array}{c}0.850^{* * * *} \\
(0.065) \\
\end{array}$ & $\begin{array}{c}0.850^{* * *} \\
(0.065) \\
\end{array}$ & $\begin{array}{c}0.851^{* * *} \\
(0.065) \\
\end{array}$ & $\begin{array}{c}0.853^{* * *} \\
(0.066) \\
\end{array}$ & $\begin{array}{c}0.855^{* * *} \\
(0.066) \\
\end{array}$ & $\begin{array}{c}1.122^{* * *} \\
(0.154)\end{array}$ & $\begin{array}{c}1.114^{* * *} \\
(0.152)\end{array}$ & $\begin{array}{c}1.118^{* * *} \\
(0.153) \\
\end{array}$ & $\begin{array}{c}1.133^{* * *} \\
(0.159) \\
\end{array}$ & $\begin{array}{c}1.150^{* * *} \\
(0.168)\end{array}$ \\
\hline Control Variables & & & & & & $\checkmark$ & $\checkmark$ & $\checkmark$ & $\checkmark$ & $\checkmark$ \\
\hline Observations & 397 & 397 & 397 & 397 & 397 & 397 & 397 & 397 & 397 & 397 \\
\hline
\end{tabular}




\subsection{Imperial Germany: Extensions of the Empirical Analysis}

In the appendix, we present multiple extensions. In the first extension, we add covariates for population size and Prussia. In the second extension, we take into account a variable that reflects variation in the Reformation's long-term impact: a district's share of Catholics. In the third extension, we calculate the BDEI score based on an alternative set of outbreak observations. In the fourth extension, we condition our analysis of landholding inequality on the relevance of agriculture in the district. In the fifth extension, we use the timing of outbreaks in a 2SLS setup to isolate exogeneous variation in mortality rates. ${ }^{42}$ In the sixth extension, we replace our distance measures to geographic features with dummy variables. In the seventh extension, we control for variability in agricultural potential to account for historical information asymmetries (Ahmed and Stasavage, 2020). In the eighth extension, we include quasi-random spatial fixed effects to address suggestions made by Pepinsky, Goodman and Ziller (2020). In the ninth extension, we use two alternative datasets of plague outbreaks to compute the BDEI score (Büntgen, Ginzler, Esper, Tegel and McMichael, 2012; Schmid, Büntgen, Easterday, Ginzler, Walløe, Bramanti and Stenseth, 2015). In the tenth extension, we use data by Nüssli and Nüssli (2008a) to introduce fixed effects based on pre-treatment administrative borders. In the eleventh extension, we consider three alternative outcome measures: (1) the combined vote share of all conservative parties (1871), (2) the combined vote share of all major liberal and moderate parties (1871), and (3) the Conservative Party's vote share in the 1874 election. In the twelfth extension, we account for cities' population sizes when computing the BDEI score. In the thirteenth extension, we manually limit the regions used to construct the BDEI score to neighboring ones. Finally, in the fourteenth extension, we account for historical agricultural potential (Galor and Özak, 2016).

\footnotetext{
${ }^{42}$ This strategy is based on the observation that the Black Death was most severe in the spring and summer and that its intensity waned over time (Benedictow, 2004; Gottfried, 1983).
} 


\subsection{Weimar Germany: Persistence of Local Political Cultures and Votes for the National Socialist Party}

In addition to the extensions discussed above, the substantively most important addition to our main empirical test is an analysis of the 1930 and July 1932 elections in Weimar Germany. Do we observe an association between the Black Death's historical intensity and the strength of the NSDAP in these critical elections? Indeed, as shown in Figure 7 and Figure 8, the electoral strength of the NSDAP in both elections is highly correlated with the Black Death's historical intensity as measured by BDEI score v1. In areas that were historically hit hardest by the Black Death, we expect the NSDAP to perform most poorly. Vice versa, in areas historically only lightly hit, we expect the NSDAP to perform best.

Table 4 and Table 5 provide further details with respect to these results, underscoring that there is a persistent negative association between historical Black Death exposure intensity and the NSDAP's vote share. In the 1930 elections, a one standard deviation increase in the BDEI score leads to a reduction in the expected vote share of the NSDAP ranging from $0.017(1.7 \%)$ to 0.028 (2.8\%) (0.160 to 0.264 standard deviations). In the elections of July 1932, a one standard deviation increase in the BDEI score leads to a reduction in the expected vote share of the NSDAP ranging from $0.034(3.4 \%)$ to $0.088(8.8 \%)(0.233$ to 0.603 standard deviations). These results indicate that important aspects of the spatial divergence in political cultures created by the Black Death persisted into the Weimar Republic, in spite of the socioeconomic and geographic dislocations ushered in by industrialization and WWI. 
Figure 7: Predicted Values Plot: BDEI Score v1 and NSDAP Vote Share (1930)

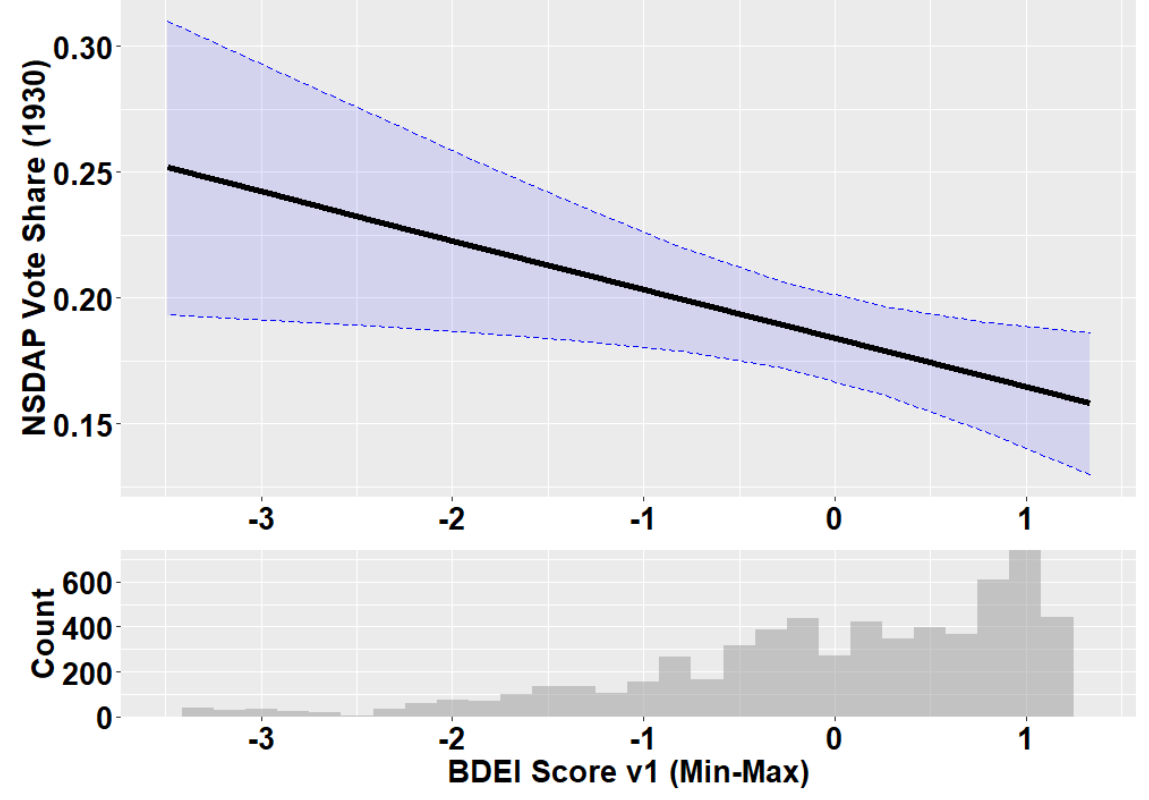

Figure 8: Predicted Values Plot: BDEI Score v1 and NSDAP Vote Share (Jul. 1932)

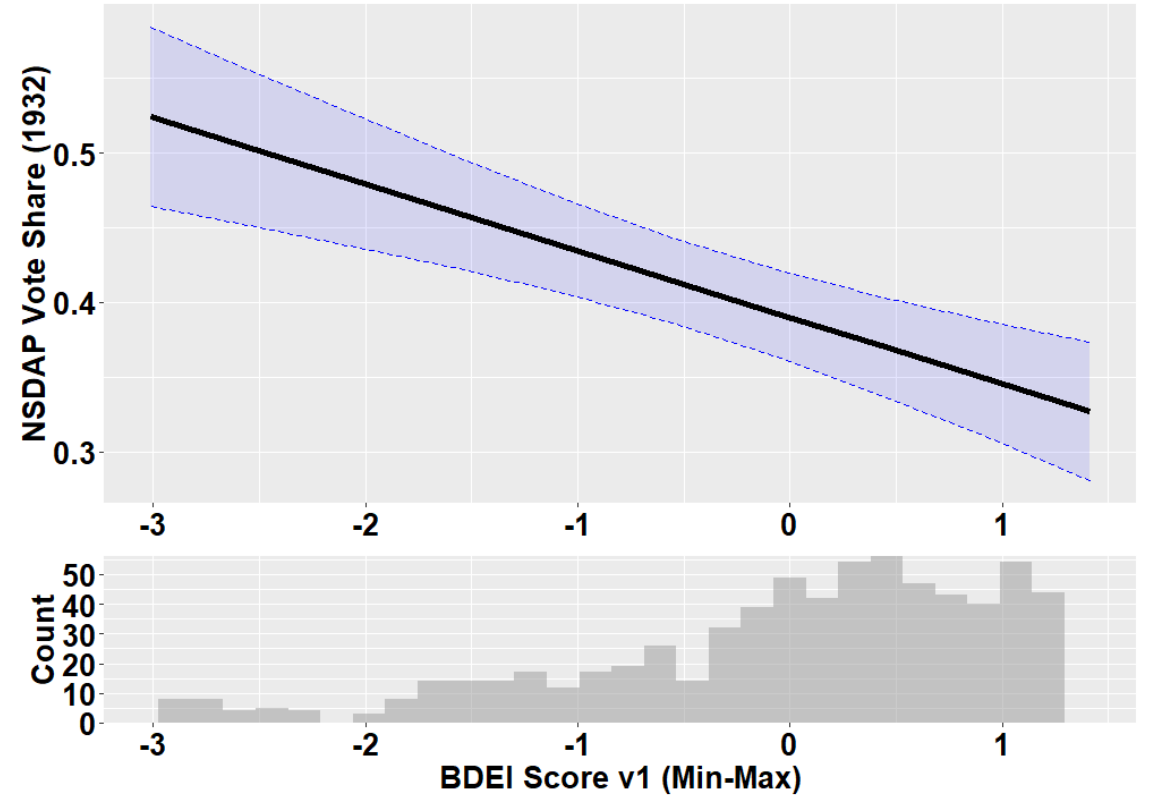


Table 4: NSDAP Vote Share (1930) (OLS)

\begin{tabular}{|c|c|c|c|c|c|c|c|c|c|c|}
\hline & \multicolumn{10}{|c|}{ Dependent variable: } \\
\hline & & & & & NSDAP Vot & Share $(193$ & & & & \\
\hline & $(1)$ & $(2)$ & $(3)$ & $(4)$ & $(5)$ & $(6)$ & $(7)$ & $(8)$ & $(9)$ & $(10)$ \\
\hline BDEI Score v1 & $\begin{array}{c}-0.019^{* *} \\
(0.008)\end{array}$ & & & & & $\begin{array}{c}-0.028^{* *} \\
(0.012)\end{array}$ & & & & \\
\hline BDEI Score v2 & & $\begin{array}{c}-0.020^{* *} \\
(0.008)\end{array}$ & & & & & $\begin{array}{c}-0.028^{* *} \\
(0.012)\end{array}$ & & & \\
\hline BDEI Score v3 & & & $\begin{array}{c}-0.020^{* *} \\
(0.008)\end{array}$ & & & & & $\begin{array}{c}-0.028^{* *} \\
(0.012)\end{array}$ & & \\
\hline BDEI Score v4 & & & & $\begin{array}{c}-0.019^{* *} \\
(0.009)\end{array}$ & & & & & $\begin{array}{c}-0.028^{* *} \\
(0.012)\end{array}$ & \\
\hline BDEI Score v5 & & & & & $\begin{array}{c}-0.017^{*} \\
(0.009)\end{array}$ & & & & & $\begin{array}{c}-0.026^{* *} \\
(0.013)\end{array}$ \\
\hline Constant & $\begin{array}{c}0.184^{* * *} \\
(0.009)\end{array}$ & $\begin{array}{c}0.184^{* * *} \\
(0.009)\end{array}$ & $\begin{array}{c}0.184^{* * *} \\
(0.009)\end{array}$ & $\begin{array}{c}0.184^{* * *} \\
(0.009)\end{array}$ & $\begin{array}{c}0.184^{* * * *} \\
(0.009)\end{array}$ & $\begin{array}{c}0.205^{* * *} \\
(0.030) \\
\end{array}$ & $\begin{array}{c}0.206^{* * *} \\
(0.031) \\
\end{array}$ & $\begin{array}{c}0.206^{* * *} \\
(0.031) \\
\end{array}$ & $\begin{array}{c}0.206^{* * *} \\
(0.032) \\
\end{array}$ & $\begin{array}{c}0.204^{* * *} \\
(0.032) \\
\end{array}$ \\
\hline Control Variables & & & & & & $\checkmark$ & $\checkmark$ & $\checkmark$ & $\checkmark$ & $\checkmark$ \\
\hline Observations & 3,347 & 3,347 & 3,347 & 3,347 & 3,347 & 3,346 & 3,346 & 3,346 & 3,346 & 3,346 \\
\hline $\mathrm{R}^{2}$ & 0.031 & 0.032 & 0.032 & 0.029 & 0.023 & 0.076 & 0.078 & 0.079 & 0.078 & 0.074 \\
\hline Adjusted $\mathrm{R}^{2}$ & 0.031 & 0.032 & 0.032 & 0.029 & 0.023 & 0.074 & 0.076 & 0.077 & 0.076 & 0.072 \\
\hline
\end{tabular}


Table 5: NSDAP Vote Share (Jul. 1932) (OLS)

\begin{tabular}{|c|c|c|c|c|c|c|c|c|c|c|}
\hline & \multicolumn{10}{|c|}{ Dependent variable: } \\
\hline & \multicolumn{10}{|c|}{ NSDAP Vote Share (Jul. 1932) } \\
\hline & (1) & $(2)$ & $(3)$ & $(4)$ & (5) & (6) & $(7)$ & $(8)$ & (9) & $(10)$ \\
\hline BDEI Score v1 & $\begin{array}{c}-0.037^{* * *} \\
(0.010)\end{array}$ & & & & & $\begin{array}{c}-0.085^{* * *} \\
(0.019)\end{array}$ & & & & \\
\hline BDEI Score v2 & & $\begin{array}{c}-0.038^{* * *} \\
(0.011)\end{array}$ & & & & & $\begin{array}{c}-0.082^{* * *} \\
(0.018)\end{array}$ & & & \\
\hline BDEI Score v3 & & & $\begin{array}{c}-0.039^{* * *} \\
(0.011)\end{array}$ & & & & & $\begin{array}{c}-0.084^{* * *} \\
(0.017)\end{array}$ & & \\
\hline BDEI Score v4 & & & & $\begin{array}{c}-0.037^{* * *} \\
(0.011)\end{array}$ & & & & & $\begin{array}{c}-0.087^{* * *} \\
(0.017)\end{array}$ & \\
\hline BDEI Score v5 & & & & & $\begin{array}{c}-0.034^{* * *} \\
(0.011)\end{array}$ & & & & & $\begin{array}{c}-0.088^{* * *} \\
(0.017)\end{array}$ \\
\hline Constant & $\begin{array}{c}0.387^{* * *} \\
(0.017) \\
\end{array}$ & $\begin{array}{c}0.387^{* * *} \\
(0.017)\end{array}$ & $\begin{array}{c}0.387^{* * *} \\
(0.017)\end{array}$ & $\begin{array}{c}0.387^{* * *} \\
(0.017)\end{array}$ & $\begin{array}{c}0.388^{* * *} \\
(0.017)\end{array}$ & $\begin{array}{c}0.488^{* * *} \\
(0.028)\end{array}$ & $\begin{array}{c}0.487^{* * *} \\
(0.028)\end{array}$ & $\begin{array}{c}0.489^{* * *} \\
(0.028)\end{array}$ & $\begin{array}{c}0.494^{* * *} \\
(0.029)\end{array}$ & $\begin{array}{c}0.498^{* * *} \\
(0.031)\end{array}$ \\
\hline Control Variables & & & & & & $\checkmark$ & $\checkmark$ & $\checkmark$ & $\checkmark$ & $\checkmark$ \\
\hline Observations & 1,037 & 1,037 & 1,037 & 1,037 & 1,037 & 1,036 & 1,036 & 1,036 & 1,036 & 1,036 \\
\hline & 0.069 & 0.071 & 0.072 & 0.068 & 0.059 & 0.227 & 0.230 & 0.236 & 0.241 & 0.239 \\
\hline Adjusted $\mathrm{R}^{2}$ & 0.068 & 0.070 & 0.071 & 0.067 & 0.058 & 0.222 & 0.225 & 0.231 & 0.236 & 0.234 \\
\hline
\end{tabular}




\subsection{Mechanisms, Part I: Pre-Reformation Germany — Introduc- tion of Participative Elections}

Next we focus on the underlying mechanisms by which we postulate the Black Death exerted a long-term effect on political outcomes in Germany. In this respect, we begin with a set of analyses that examine pre-Reformation Germany. We study outcomes prior to the Protestant Reformation, which began in 1517 , to rule out the possibility that it could be responsible for the outcomes observed in Imperial Germany. By showing that the Black Death is associated with key changes in proto-democratic institutions by 1500 (when compared to 1300), we demonstrate that some of the mechanisms discussed can be observed many years before the Reformation impacted Germany's political landscape.

Table 6 shows results for introduction of participative elections (1300-1500) for 325 towns. The results indicate that towns that were more strongly exposed to the Black Death were significantly more likely to adopt participative institutions by 1500 .

Table 6: Introduction of Participative Elections (1300-1500) (Logit)

\begin{tabular}{|c|c|c|c|c|c|}
\hline & \multicolumn{5}{|c|}{ Dependent variable: } \\
\hline & \multicolumn{5}{|c|}{ Introduction of Participative Elections (1300-1500) } \\
\hline & (1) & $(2)$ & $(3)$ & $(4)$ & $(5)$ \\
\hline BDEI Score v1 & $\begin{array}{c}0.572^{* * *} \\
(0.184)\end{array}$ & & & & \\
\hline BDEI Score v2 & & $\begin{array}{c}0.527^{* * *} \\
(0.174)\end{array}$ & & & \\
\hline BDEI Score v3 & & & $\begin{array}{c}0.466^{* * *} \\
(0.166)\end{array}$ & & \\
\hline BDEI Score v4 & & & & $\begin{array}{l}0.397^{* *} \\
(0.161)\end{array}$ & \\
\hline BDEI Score v5 & & & & & $\begin{array}{c}0.322^{* *} \\
(0.159)\end{array}$ \\
\hline Constant & $\begin{array}{c}-1.836^{* * *} \\
(0.171)\end{array}$ & $\begin{array}{c}-1.821^{* * *} \\
(0.168)\end{array}$ & $\begin{array}{c}-1.802^{* * *} \\
(0.165)\end{array}$ & $\begin{array}{c}-1.782^{* * *} \\
(0.162)\end{array}$ & $\begin{array}{c}-1.764^{* * *} \\
(0.160) \\
\end{array}$ \\
\hline Observations & 325 & 325 & 325 & 325 & 325 \\
\hline Log Likelihood & -132.288 & -132.751 & -133.617 & -134.660 & -135.714 \\
\hline Akaike Inf. Crit. & 268.575 & 269.501 & 271.235 & 273.319 & 275.428 \\
\hline
\end{tabular}

Note: Logit

${ }^{*} \mathrm{p}<0.1 ;{ }^{* *} \mathrm{p}<0.05 ;{ }^{* * *} \mathrm{p}<0.01$ 
In Table 7, we add a variety of control variables, including geographic factors. While the results are at or below the threshold of statistical significance in two specifications, the direction of the effect remains the same. Indeed, the lower level of significance is likely due to the much smaller number of cases for which covariate data is available. Overall, the evidence suggests that demographic collapse from the Black Death set in motion institutional changes that are consistent with the patterns of political behavior observed in the nineteenth century.

Table 7: Introduction of Participative Elections (1300-1500) (Logit)

\begin{tabular}{|c|c|c|c|c|c|}
\hline & \multicolumn{5}{|c|}{ Dependent variable: } \\
\hline & \multicolumn{5}{|c|}{ Introduction of Participative Elections (1300-1500) } \\
\hline & $(1)$ & $(2)$ & $(3)$ & $(4)$ & $(5)$ \\
\hline BDEI Score v1 & $\begin{array}{l}2.203^{* *} \\
(1.030)\end{array}$ & & & & \\
\hline BDEI Score v2 & & $\begin{array}{l}2.022^{* *} \\
(0.965)\end{array}$ & & & \\
\hline BDEI Score v3 & & & $\begin{array}{l}1.751^{* *} \\
(0.890)\end{array}$ & & \\
\hline BDEI Score v4 & & & & $\begin{array}{l}1.326^{*} \\
(0.777)\end{array}$ & \\
\hline BDEI Score v5 & & & & & $\begin{array}{c}0.861 \\
(0.646)\end{array}$ \\
\hline Constant & $\begin{array}{c}9.264 \\
(5.827)\end{array}$ & $\begin{array}{c}8.204 \\
(5.522)\end{array}$ & $\begin{array}{c}6.583 \\
(5.118)\end{array}$ & $\begin{array}{c}4.502 \\
(4.661)\end{array}$ & $\begin{array}{c}2.593 \\
(4.279)\end{array}$ \\
\hline Control Variables & $\checkmark$ & $\checkmark$ & $\checkmark$ & $\checkmark$ & $\checkmark$ \\
\hline Observations & 86 & 86 & 86 & 86 & 86 \\
\hline Log Likelihood & -28.884 & -29.010 & -29.306 & -29.854 & -30.468 \\
\hline Akaike Inf. Crit. & 81.769 & 82.021 & 82.612 & 83.707 & 84.937 \\
\hline
\end{tabular}

\subsection{Mechanisms, Part II: Early Nineteenth-Century Prussia - The Black Death and the Footprints of Serfdom}

In the final set of empirical analyses, we analyze socioeconomic outcomes in early nineteenthcentury Prussia. These analyses are meant to evaluate if geographical variation in Black Death exposure intensity is associated with proxy measures of the strength of serfdom prior 
to the late nineteenth-century transition to mass politics.

Our results indicate that both the proportion of large estates (1816) and the proportion of agricultural servants (1816/1819) are clearly associated with the Black Death's historical intensity. Specifically, Table 8 shows a persistent negative relationship between the $B D E I$ score and the proportion of large estates, indicating that in areas that were hit hardest by the Black Death, we observe the smallest relative number of large estates in 1816. Moreover, Table 9 shows a similar pattern when it comes to agricultural servants as a proportion of the overall population. Overall, the results indicate that areas hit hardest by the Black Death have a significantly smaller number of agricultural servants, indicating a less hierarchical and less agriculturally-centered economy. These findings are fully compatible with our suggested mechanisms. 
Table 8: Proportion of Large Estates (1816) (OLS)

\begin{tabular}{|c|c|c|c|c|c|c|c|c|c|c|}
\hline & \multicolumn{10}{|c|}{ Dependent variable: } \\
\hline & \multicolumn{10}{|c|}{ Proportion of Large Estates (1816) } \\
\hline & $(1)$ & $(2)$ & $(3)$ & $(4)$ & $(5)$ & $(6)$ & $(7)$ & $(8)$ & $(9)$ & $(10)$ \\
\hline BDEI Score v1 & $\begin{array}{c}-0.010^{* * *} \\
(0.001)\end{array}$ & & & & & $\begin{array}{c}-0.012^{* * *} \\
(0.002)\end{array}$ & & & & \\
\hline BDEI Score v2 & & $\begin{array}{c}-0.010^{* * *} \\
(0.001)\end{array}$ & & & & & $\begin{array}{c}-0.012^{* * *} \\
(0.002)\end{array}$ & & & \\
\hline BDEI Score v3 & & & $\begin{array}{c}-0.010^{* * *} \\
(0.001)\end{array}$ & & & & & $\begin{array}{c}-0.013^{* * *} \\
(0.002)\end{array}$ & & \\
\hline BDEI Score v4 & & & & $\begin{array}{c}-0.009^{* * *} \\
(0.001)\end{array}$ & & & & & $\begin{array}{c}-0.013^{* * *} \\
(0.002)\end{array}$ & \\
\hline BDEI Score v5 & & & & & $\begin{array}{c}-0.009^{* * *} \\
(0.001)\end{array}$ & & & & & $\begin{array}{c}-0.014^{* * *} \\
(0.003)\end{array}$ \\
\hline Constant & $\begin{array}{c}0.017^{* * *} \\
(0.001)\end{array}$ & $\begin{array}{c}0.017^{* * *} \\
(0.001)\end{array}$ & $\begin{array}{c}0.017^{* * *} \\
(0.001)\end{array}$ & $\begin{array}{c}0.017^{* * *} \\
(0.001)\end{array}$ & $\begin{array}{c}0.017^{* * *} \\
(0.001)\end{array}$ & $\begin{array}{c}0.023^{* * *} \\
(0.006)\end{array}$ & $\begin{array}{c}0.025^{* * *} \\
(0.005)\end{array}$ & $\begin{array}{c}0.026^{* * *} \\
(0.005)\end{array}$ & $\begin{array}{c}0.027^{* * *} \\
(0.006)\end{array}$ & $\begin{array}{c}0.027^{* * *} \\
(0.006)\end{array}$ \\
\hline Control Variables & & & & & & $\checkmark$ & $\checkmark$ & $\checkmark$ & $\checkmark$ & $\checkmark$ \\
\hline Observations & 267 & 267 & 267 & 267 & 267 & 266 & 266 & 266 & 266 & 266 \\
\hline $\mathrm{R}^{2}$ & 0.213 & 0.215 & 0.209 & 0.196 & 0.179 & 0.413 & 0.426 & 0.431 & 0.432 & 0.430 \\
\hline Adjusted $\mathrm{R}^{2}$ & 0.210 & 0.212 & 0.206 & 0.193 & 0.176 & 0.397 & 0.411 & 0.416 & 0.417 & 0.414 \\
\hline
\end{tabular}


Table 9: Proportion of Agricultural Servants (of Total Population) (1816/1819) (OLS)

\begin{tabular}{|c|c|c|c|c|c|c|c|c|c|c|}
\hline & \multicolumn{10}{|c|}{ Dependent variable: } \\
\hline & \multicolumn{10}{|c|}{ Proportion of Agricultural Servants (of Total Population) (1816/1819) } \\
\hline & $(1)$ & $(2)$ & (3) & $(4)$ & $(5)$ & $(6)$ & $(7)$ & $(8)$ & $(9)$ & $(10)$ \\
\hline BDEI Score v1 & $\begin{array}{c}-0.012^{* * *} \\
(0.002)\end{array}$ & & & & & $\begin{array}{c}-0.018^{* * *} \\
(0.005)\end{array}$ & & & & \\
\hline BDEI Score v2 & & $\begin{array}{c}-0.012^{* * *} \\
(0.002)\end{array}$ & & & & & $\begin{array}{c}-0.018^{* * *} \\
(0.004)\end{array}$ & & & \\
\hline BDEI Score v3 & & & $\begin{array}{c}-0.012^{* * *} \\
(0.002)\end{array}$ & & & & & $\begin{array}{c}-0.018^{* * *} \\
(0.004)\end{array}$ & & \\
\hline BDEI Score v4 & & & & $\begin{array}{c}-0.012^{* * *} \\
(0.002)\end{array}$ & & & & & $\begin{array}{c}-0.019^{* * *} \\
(0.005)\end{array}$ & \\
\hline BDEI Score v5 & & & & & $\begin{array}{c}-0.012^{* * *} \\
(0.002)\end{array}$ & & & & & $\begin{array}{c}-0.020^{* * *} \\
(0.005)\end{array}$ \\
\hline Constant & $\begin{array}{c}0.092^{* * *} \\
(0.002)\end{array}$ & $\begin{array}{c}0.092^{* * *} \\
(0.002)\end{array}$ & $\begin{array}{c}0.092^{* * *} \\
(0.002)\end{array}$ & $\begin{array}{c}0.092^{* * *} \\
(0.002)\end{array}$ & $\begin{array}{c}0.092^{* * *} \\
(0.002)\end{array}$ & $\begin{array}{c}0.160^{* * *} \\
(0.011) \\
\end{array}$ & $\begin{array}{c}0.161^{* * *} \\
(0.011) \\
\end{array}$ & $\begin{array}{c}0.161^{* * *} \\
(0.011) \\
\end{array}$ & $\begin{array}{c}0.162^{* * *} \\
(0.011) \\
\end{array}$ & $\begin{array}{c}0.162^{* * *} \\
(0.011) \\
\end{array}$ \\
\hline Control Variables & & & & & & $\checkmark$ & $\checkmark$ & $\checkmark$ & $\checkmark$ & $\checkmark$ \\
\hline Observations & 280 & 280 & 280 & 280 & 280 & 279 & 279 & 279 & 279 & 279 \\
\hline $\mathrm{R}^{2}$ & 0.103 & 0.101 & 0.100 & 0.098 & 0.095 & 0.296 & 0.299 & 0.300 & 0.300 & 0.298 \\
\hline Adjusted $\mathrm{R}^{2}$ & 0.100 & 0.098 & 0.096 & 0.095 & 0.092 & 0.278 & 0.281 & 0.282 & 0.282 & 0.280 \\
\hline
\end{tabular}




\section{Conclusion}

Contemporary social science emphasizes the importance of actions taken during critical junctures in explanations of differences in the nature, scope, and quality of government across societies (cf. Collier and Collier, 1991; Mahoney, 2001). As moments in time, critical junctures are defined by significant upheaval and fluidity (Capoccia, 2015): Institutional structures and social arrangements long taken for granted are suddenly amenable to changes that would have been inconceivable in normal circumstances. Such windows for change do not open easily. The antecedent to a critical juncture may be a shock that profoundly reorders economic circumstances and/or the balance of de facto power in a society (Roberts, 2002; Tarrow, 2017). Among the various types of shocks that may produce such an alteration in circumstances, demographic collapses due to pandemics surely number among the most consequential.

Our study examines the long-term legacy of one of the most profound demographic shocks in European history: the loss of life due to the Black Death in the mid-fourteenth century. Concentrating on the historical experience of the German-speaking areas of Europe from the arrival of the Black Death until the onset of the German Empire in 1871 and beyond, the study explicitly laid out all four stages of analysis necessary for establishing the importance of a critical juncture (Collier and Munck, 2017): (1) characterization of the shock (i.e., the intensity of exposure to the Black Death); (2) the critical juncture itself (i.e., the decision to roll back or augment labor coercion); (3) the mechanisms of production of the legacy (i.e., changes in economic arrangements and political institutions resulting from changes in labor coercion); (4) the legacy (i.e., electoral behavior in the late nineteenth century and Weimar Republic).

Empirically, our paper shows that areas more intensely affected by the Black Death de- 
veloped more inclusive political institutions at the local level and more equitable ownership of land, both reflecting a fundamentally changed political-economic equilibrium. Contrariwise, those areas less affected by the Black Death maintained political institutions and land ownership patterns that concentrated political and economic power in a small elite. In the first set of areas, voters in the late nineteenth century would come to reject the Conservative Party in electoral competition, an outcome indicative of autonomy of voters from the directives of the landed nobility. In the second set of areas, voters would overwhelmingly cast their votes in favor of the Conservative Party, indicative not only of an anti-democratic political culture, but also of the ability of the landed elite to guide voters' decisions at the ballot box. By restructuring political institutions and social organization at the local level, the Black Death had significant consequences for how citizens would come to engage in mass politics.

Importantly, the remarkable spatial divergence in political cultures created by the Black Death created a political conflict between conservative and progressive forces that persisted well into the Weimar Republic, one that is evident in the clear association between historical Black Death exposure and votes for the National Socialist Party. The NSDAP's extremely hierarchical and illiberal political views - which later led to barbaric crimes of unprecedented magnitude - found fertile ground in the areas of Germany that had limited historical experience with democratic participation at the local level. Thus, the Black Death not only shaped institutional development in Central Europe during the early modern period and electoral outcomes during the nineteenth century, but its echoes may be found in the party politics of the Weimar Republic's doomed experiment with mass democracy.

What lessons does the Black Death offer about the potentially transformative role of pandemics more generally? One important lesson is that the depth of the shock matters. As 
the Black Death made its way through Europe, it imposed physical and emotional suffering of an incalculable magnitude, profoundly darkening the tenor of literature, music, and the visual arts. Yet in spite of the death and suffering associated with the disease outbreak, the world inherited by survivors and their descendants in areas ravaged by the Black Death was in many ways favorable to the world in which their ancestors had long toiled. Massive demographic collapse had improved the bargaining power of labor, leading to major changes in social organization and political institutions. These developments would improve living standards and provide opportunities for meaningful political engagement. In a dark twist of irony, the experience of the Black Death demonstrates that the long-term political independence of labor may have blossomed from the graves of workers.

As a general matter, however, one should not expect that pandemics will usually have these types of consequences. In order to radically restructure labor relations - the catalyst for the subsequent social and political changes wrought by the Black Death - a disease shock has to be very large, affect individuals in their prime working age, and not be easily reversible. Pandemics that infect great numbers of individuals but which have relatively low mortality rates - such as the Spanish Flu of 1918 or today's Covid-19 outbreak - do not change the labor supply to the extent that it would fundamentally alter factor prices. The same is true for pandemics that have a high mortality rate but limited contagiousness, as was the case for HIV/AIDS prior to the widespread use of antiretroviral drugs. Diseases that primarily afflict children, such as measles and polio, also do not reconfigure relative factor prices - at least not in the long run - as fertility strategies may compensate for heightened mortality in children (cf. Hossain, Phillips and LeGrand, 2007).

To produce a labor market shock that generates dynamics comparable to that initiated by the Black Death, a pandemic would have to combine high contagiousness with high 
mortality for working age adults. The Ebola virus seemingly had this potential, but the recent development of a vaccine has thankfully reduced the threat to life posed by this disease. Although no obvious alternative threat lies on the horizon, the present combination of high population density and unprecedented global interconnectedness will surely make the next great pandemic all the more destructive when (not if) it does emerge. What the Black Death offers us, at the end, is an important reminder: When the next wave of destruction emerges, the particular set of labor repressive institutions of our contemporary era may be washed away in its wake. 


\section{References}

Acemoglu, Daron. 2010. "Institutions, Factor Prices, and Taxation: Virtues of Strong States?" American Economic Review 100(2):115-19.

Acemoglu, Daron and Alexander Wolitzky. 2011. "The Economics of Labor Coercion." Econometrica 79(2):555-600.

Acemoglu, Daron and James A. Robinson. 2006. Economic Origins of Democracy and Dictatorship. Cambridge, UK: Cambridge University Press.

Acemoglu, Daron and James A. Robinson. 2012. Why Nations Fail: The Origins of Power, Prosperity, and Poverty. New York, NY: Crown Books.

Acemoglu, Daron and James A. Robinson. 2019. The Narrow Corridor: States, Societies, and the Fate of Liberty. New York, NY: Penguin Press.

Acemoglu, Daron, Simon Johnson and James A. Robinson. 2001. "The Colonial Origins of Comparative Development: An Empirical Investigation." American Economic Review 91(5):1369-1401.

Acharya, Avidit, Matthew Blackwell and Maya Sen. 2018. Deep Roots: How Slavery Still Shapes Southern Politics. Princeton, NJ: Princeton University Press.

Ahmed, Ali T. and David Stasavage. 2020. "Origins of Early Democracy." American Political Science Review 114(2):502-518.

Alesina, Alberto and Paola Giuliano. 2015. "Culture and Institutions." Journal of Economic Literature 53(4):898-944.

Alfani, Guido. 2015. "Economic Inequality in Northwestern Italy: A Long-Term View." Journal of Economic History 75:1058-1096.

Alfani, Guido and Francesco Ammannati. 2017. "Long-Term Trends in Economic Inequality: The Case of the Florentine State, c. 1300-1800." Economic History Review 70:1072- 
1102.

Alfani, Guido, Victoria Gierok and Felix Schaff. 2020. "Economic Inequality in Preindustrial Germany, ca. 1300 - 1850." Working Paper, Available at: https://www.researchgate.net/publication/339781476_Economic_Inequality _in_Preindustrial_Germany_ca_1300_-_1850.

Almond, Douglas. 2006. "Is the 1918 Influenza Pandemic Over? Long-Term Effects of In Utero Influenza Exposure in the Post-1940 US Population." Journal of Political Economy 114(4):672-712.

Almond, Gabriel and Sidney Verba. 1963. The Civic Culture: Political Attitudes and Democracy in Five Nations. Princeton, NJ: Princeton University Press.

Anderson, Margaret Lavinia. 1993. "Voter, Junker, Landrat, Priest: The Old Authorities and the New Franchise in Imperial Germany." The American Historical Review 98(5):14481474.

Anderson, Margaret Lavinia. 2000. Practicing Democracy: Elections and Political Culture in Imperial Germany. Princeton, NJ: Princeton University Press.

Anderson, Siwan, Patrick Francois and Ashok Kotwal. 2015. "Clientelism in Indian Villages." American Economic Review 105(6):1780-1816.

Anheier, Helmut. 2003. Movement Development and Organizational Networks: The Role of 'Single Members' in the German Nazi Party, 1925-30. In Social Movements and Networks: Relational Approaches to Collective Action, ed. Mario Diani Doug McAdam. Oxford, UK: Oxford University Press pp. 49-74.

Ansell, Ben W. and David J. Samuels. 2014. Inequality and Democratization: An EliteCompetition Approach. Cambridge, UK: Cambridge University Press.

Ardanaz, Martin and Isabela Mares. 2014. "Labor Shortages, Rural Inequality, and Democ- 
ratization." Comparative Political Studies 47(12):1639-1669.

Arsenschek, Robert and Daniel Ziblatt. 2008. "Complete Reichstag Election Disputes Dataset, 1871-1914." https://dataverse.harvard.edu/dataverse/dziblatt.

Ault, Brian and William Brustein. 1998. "Joining the Nazi Party: Explaining the Political Geography of NSDAP Membership, 1925-1933." American Behavioral Scientist 41(9):1304-1323.

Baland, Jean-Marie and James A. Robinson. 2008. "Land and Power: Theory and Evidence from Chile." American Economic Review 98(5):1737-65.

Bartels, Larry M. 2008. Unequal Democracy: The Political Economy of the New Gilded Age. Princeton, NJ: Princeton University Press.

Becker, Sascha O, Francesco Cinnirella, Erik Hornung and Ludger Woessmann. 2014. "iPEHD - the ifo Prussian Economic History Database." Historical Methods: A Journal of Quantitative and Interdisciplinary History 47(2):57-66.

Benedictow, Ole J. 2004. The Black Death, 1346-1353: the Complete History. Woodbridge, UK: Boydell \& Brewer.

Bentzen, Jeanet, Jacob Gerner Hariri and James A. Robinson. 2015. "The Indigenous Roots of Representative Democracy." NBER Working Paper No.w21193, https: //www.nber .org/papers/w21193.

Beramendi, Pablo and Christopher J. Anderson. 2008. Democracy, Inequality, and Representation in Comparative Perspective. New York, NY: Russell Sage Foundation.

Berdahl, Robert M. 1972. "Conservative Politics and Aristocratic Landholders in Bismarckian Germany." The Journal of Modern History 44(1):2-20.

Berdahl, Robert M. 1988. The Politics of the Prussian Nobility: The Development of a Conservative Ideology, 1770-1848. Princeton, NJ: Princeton University Press. 
Bergdolt, Klaus. 2006. Die Pest: Geschichte des Schwarzen Todes. Munich, Germany: C.H. Beck.

Berman, Sheri. 1997. "Civil Society and the Collapse of the Weimar Republic." World Politics 49(3):401-429.

Berman, Sheri E. 2001. "Modernization in Historical Perspective: The Case of Imperial Germany." World Politics 53(3):431-462.

Blanning, Tim. 2012. "The Holy Roman Empire of the German Nation Past and Present." Historical Research 85(227):57-70.

Blickle, Peter. 1986. "Communalism, Parliamentarism, Republicanism." Parliaments, Estates, and Representation 6(1):1-13.

Blum, Jerome. 1957. "The Rise of Serfdom in Eastern Europe." The American Historical Review 62(4):807-836.

Blum, Jerome. 1960. The European Peasantry: From the Fifteenth to the Nineteenth Century. Washington, DC: American Historical Association.

Blum, Jerome. 1971. "The Internal Structure and Polity of the European Village Community from the Fifteenth to the Nineteenth Century." The Journal of Modern History 43(4):541-576.

Boix, Carles. 2003. Democracy and Redistribution. Cambridge, UK: Cambridge University Press.

Bonds, Matthew H., Donald C. Keenan, Pejman Rohani and Jeffrey D. Sachs. 2010. "Poverty Trap Formed by the Ecology of Infectious Diseases." Proceedings of the Royal Society B: Biological Sciences 277(1685):1185-1192.

Bossak, Brian H. and Mark R. Welford. 2016. Spatio-Temporal Characteristics of the Medieval Black Death. In Spatial Analysis in Health Geography, ed. Pavlos Kanaroglou, 
Eric Delmelle and Antonio Páez. New York, NY: Routledge pp. 93-106.

Brady Jr., Thomas A. 1996. Economic and Social Institutions. In Germany: A New Social and Economic History, Vol. 1: 1450-1630, ed. Bob Scribner. London, UK: Arnold pp. 259-290.

Brenner, Robert. 1976. "Agrarian Class Structure and Economic Development in PreIndustrial Europe." Past \& Present 70(1):30-75.

Brusco, Valeria, Marcelo Nazareno and Susan C. Stokes. 2004. "Vote Buying in Argentina." Latin American Research Review 39(2):66-88.

Brustein, William. 1996. The Logic of Evil: The Social Origins of the Nazi Party, 1925-1933. New Haven, CT: Yale University Press.

Büntgen, Ulf, Christian Ginzler, Jan Esper, Willy Tegel and Anthony J. McMichael. 2012. "Digitizing Historical Plague." Clinical Infectious Diseases 55(11):1586-1588.

Büsch, Otto. 1997. Military System and Social Life in Old Regime Prussia, 1713-1807: The Beginnings of the Social Militarization of Prusso-German Society. Boston, MA: Brill. Campbell, Bruce M. S. 2016. The Great Transition: Climate, Disease, and Society in the Late Medieval World. Cambridge, UK: Cambridge University Press.

Capoccia, Giovanni. 2015. Critical Junctures and Institutional Change. In Advances in Comparative-Historical Analysis, ed. James Mahoney and Kathleen Thelen. Cambridge, UK: Cambridge University Press pp. 147-179.

Carsten, Francis Ludwig. 1954. The Origins of Prussia. Oxford, UK: Clarendon Press.

Carsten, Francis Ludwig. 1959. Princes and Parliaments in Germany: From the Fifteenth to the Eighteenth Century. New York, NY: Oxford University Press.

Cerman, Markus. 2012. Villagers and Lords in Eastern Europe, 1300-1800. New York, NY: Palgrave Macmillan. 
Christakos, George, Ricardo A. Olea, Marc L. Serre, Lin-Lin Wang and Hwa-Lung Yu. 2005. Interdisciplinary Public Health Reasoning and Epidemic Modelling: the Case of Black Death. Berlin, Germany: Springer.

Clark, Christopher. 2006. Iron Kingdom: The Rise and Downfall of Prussia, 1600-1947. Cambridge, MA: Harvard University Press.

Collier, David and Gerardo L. Munck. 2017. "Building Blocks and Methodological Challenges: A Framework for Studying Critical Junctures." Qualitative and Multi-Method Research 15:2-9.

Collier, Ruth Berins and David Collier. 1991. Shaping the Political Arena: Critical Junctures, Trade Unions, and the State in Latin America. Princeton, NJ: Princeton University Press.

Dee, Thomas S. 2004. "Are there Civic Returns to Education?" Journal of Public Economics 88(9-10):1697-1720.

Diamond, Jared M. 1998. Guns, Germs and Steel: a Short History of Everybody for the Last 13,000 Years. New York, NY: Random House.

Dippel, Christian, Avner Greif and Daniel Trefler. 2016. "The Rents from Trade and Coercive Institutions: Removing the Sugar Coating." Rotman School of Management Working Paper (2864727).

Dittmar, Jeremiah E. and Ralf R. Meisenzahl. 2019. "Public Goods Institutions, Human Capital, and Growth: Evidence from German History." The Review of Economic Studies 87(2):959-996.

Domar, Evsey D. 1970. "The Causes of Slavery or Serfdom: a Hypothesis." Journal of Economic History 30(1):18-32.

Eley, Geoff. 1986. The German Right, 1860-1945: How It Changed. In From Unification to 
Nazism: Reinterpreting the German Past, ed. Geoff Eley. Boston, MA: Allen \& Unwin pp. 171-199.

European Environment Agency. 2020. "WISE Large rivers and large lakes." https:// www. eea.europa.eu/data-and-maps/data/wise-large-rivers-and-large-lakes, Data Accessed April 20, 2020.

Falter, Jürgen W and Dirk Hänisch. 1990. "Election and Social Data of the Districts and Municipalities of the German Empire from 1920 to 1933. GESIS Data Archive, Cologne. ZA8013 Data file Version 1.0.0." https://doi.org/10.4232/1.8013, Data Accessed October 27, 2020.

Finan, Frederico and Laura Schechter. 2012. "Vote-Buying and Reciprocity." Econometrica 80(2):863-881.

Finley, Theresa and Mark Koyama. 2018. "Plague, Politics, and Pogroms: The Black Death, the Rule of Law, and the Persecution of Jews in the Holy Roman Empire." The Journal of Law and Economics 61(2):253-277.

Flint, Colin. 1998. "Forming Electorates, Forging Spaces: The Nazi Party Vote and the Social Construction of Space." American Behavioral Scientist 41(9):1282-1303.

Flint, Colin. 2000. "Electoral Geography and the Social Construction of Space: The Example of the Nazi Party in Baden, 1924-1932." GeoJournal 51(3):145-156.

Friedrichs, Christopher R. 1996. German Social Structure, 1300-1600. In Germany: A New Social and Economic History, Vol. 1: 1450-1630, ed. Bob Scribner. London, UK: Arnold pp. 233-258.

Frøland, Hans Otto, Tor Georg Jakobsen and Peder Berrefjord Osa. 2019. "Two Germanys? Investigating the Religious and Social Base of the 1930 Nazi Electorate." Social Science History 43(4):765-784. 
Frost, Robert. 2012. The Impact of War: The Holy Roman Empire and Poland-Lithuania, c. 1600-1806. In The Holy Roman Empire, 1495-1806: A European Perspective, ed. Robert J. W. Evans and Peter H. Wilson. Boston, MA: Brill pp. 237-257.

Frye, Timothy, Ora John Reuter and David Szakonyi. 2014. "Political Machines at Work: Voter Mobilization and Electoral Subversion in the Workplace." World Politics 66(2):195-228.

Gallup, John Luke and Jeffrey D. Sachs. 2001. "The Economic Burden of Malaria." The American Journal of Tropical Medicine and Hygiene 64(1_suppl):85-96.

Galor, Oded and Ömer Özak. 2015. "Land Productivity and Economic Development: Caloric Suitability vs. Agricultural Suitability." Working Paper, No. 2015-5, Brown University, Department of Economics, Providence, RI, http://hdl .handle.net/10419/145428.

Galor, Oded and Ömer Özak. 2016. "The Agricultural Origins of Time Preference." American Economic Review 106(10):3064-3103.

GeoNames. 2020. "GeoNames Geographical Database." http://www.geonames.org/, Accessed April 4, 2020.

Gerschenkron, Alexander. 1966. Bread and Democracy in Germany. New York, NY: Howard Fertig.

Gilens, Martin. 2012. Affluence and Influence: Economic Inequality and Political Power in America. Princeton, NJ: Princeton University Press.

Gingerich, Daniel W. 2020. "Buying Power: Electoral Strategy before the Secret Vote." American Political Science Review 114(4):1086-1102.

Gingerich, Daniel W. and Danilo Medeiros. 2020. "Vote Secrecy With Diverse Voters." Comparative Political Studies 53(3-4):567-600.

Gingerich, Daniel W. and Luis Fernando Medina. 2013. "The Endurance and Eclipse of 
the Controlled Vote: a Formal Model of Vote Brokerage Under the Secret Ballot." Economics \& Politics 25(3):453-480.

Giuliano, Paola and Nathan Nunn. 2013. "The Transmission of Democracy: From the Village to the Nation-State." American Economic Review 103:86-92.

Gottfried, Robert S. 1983. The Black Death: Natural and Human Disaster in Medieval Europe. New York, NY: The Free Press.

Hahn, Hans-Werner. 2011. Die Industrielle Revolution in Deutschland. Oldenbourg Verlag.

Hall, Peter A. and David Soskice. 2001. Varieties of Capitalism: the Institutional Foundations of Comparative Advantage. Oxford, UK: Oxford University Press.

Herlihy, David. 1997. The Black Death and the Transformation of the West. Cambridge, MA: Harvard University Press.

Hilton, Rodney Howard. 1969. The Decline of Serfdom in Medieval England. London, UK: Palgrave MacMillan.

Homola, Jonathan, Miguel M. Pereira and Margit Tavits. 2020a. "Fixed Effects and Post-Treatment Bias in Legacy Studies." OSF Preprints, https://osf.io/b945a/ download, Accessed October 20, 2020.

Homola, Jonathan, Miguel M. Pereira and Margit Tavits. 2020b. "Legacies of the Third Reich: Concentration Camps and Out-Group Intolerance." American Political Science Review 114(2):573-590.

Hossain, Mian Bazle, James F. Phillips and Thomas K. LeGrand. 2007. "The Impact of Childhood Mortality on Fertility in Six Rural Thanas of Bangladesh." Demography $44(4): 771-784$.

Hribar, Georgeanne. 2016. "Medieval European Trade Cities." https://www.arcgis .com/home/item.html?id=6e1f6f76cd57498185cd7c0c3ee608eb, Accessed October 
29, 2020.

Hübinger, Gangolf. 2008. „Sozialmoralisches Milieu“. Ein Grundbegriff der deutschen Geschichte. In Soziale Konstellation und historische Perspektive: Festschrift für M. Rainer Lepsius, ed. Steffen Sigmund, Gert Albert, Agathe Bienfait and Mateusz Stachura. Wiesbaden, Germany: VS Verlag für Sozialwissenschaften pp. 207-227.

Jedwab, Remi, Noel D. Johnson and Mark Koyama. 2019a. "Negative Shocks and Mass Persecutions: Evidence from the Black Death." Journal of Economic Growth 24(4):345395.

Jedwab, Remi, Noel D. Johnson and Mark Koyama. 2019b. "Pandemics, Places, and Populations: Evidence from the Black Death." CESifo Working Paper No. 7524, Available at SSRN: https://ssrn.com/abstract=3343855.

King, Gary, Ori Rosen, Martin Tanner and Alexander F. Wagner. 2008. "Ordinary Economic Voting Behavior in the Extraordinary Election of Adolf Hitler." The Journal of Economic History 68(4):951-996.

Kitschelt, Herbert and Steven Wilkinson. 2007. Citizen-Politician Linkages: An Introduction. In Patrons, Clients, and Policies, ed. Herbert Kitschelt and Steven Wilkinson. Cambridge, UK: Cambridge University Press pp. 1-49.

Klein, Alexander and Sheilagh Ogilvie. 2017. "Was Domar Right? Serfdom and Factor Endowments in Bohemia." CEPR Discussion Paper No. DP12388, Available at SSRN: https://ssrn. com/abstract=3057322.

Lawson, Chappell and Kenneth F. Greene. 2014. "Making Clientelism Work: How Norms of Reciprocity Increase Voter Compliance." Comparative Politics 47(1):61-85.

Lepsius, M. Rainer. 1966. Parteiensystem und Sozialstruktur. Zum Problem der Demokratisierung der deutschen Gesellschaft. In Wirtschaft, Geschichte und 
Wirtschaftsgeschichte: Festschrift zum 65. Geburtstag von Friedrich Lütge, ed. M. Rainer Lepsius and Abel Wilhelm. Stuttgart, Germany: Fischer pp. 371-393.

Lewin, Kurt. 1943. "The Special Case of Germany." Public Opinion Quarterly 7(4):555-566. Mahoney, James. 2001. The Legacies of Liberalism: Path Dependence and Political Regimes in Central America. Baltimore, MD: Johns Hopkins University Press.

Mares, Isabela. 2015. From Open Secrets to Secret Voting: Democratic Electoral Reforms and Voter Autonomy. Cambridge, UK: Cambridge University Press.

Mares, Isabela and Boliang Zhu. 2015. "The Production of Electoral Intimidation: Economic and Political Incentives." Comparative Politics 48(1):23-43.

Mazower, Mark. 2009. Hitler's Empire: How the Nazis Ruled Europe. New York, NY: Penguin.

Milligan, Kevin, Enrico Moretti and Philip Oreopoulos. 2004. "Does Education Improve Citizenship? Evidence from the United States and the United Kingdom." Journal of Public Economics 88(9-10):1667-1695.

Moore, Barrington Jr. 1966. Social Origins of Dictatorship and Democracy: Lord and Peasant in the Making of the Modern World. Boston, MA: Beacon.

More, Alexander F., Nicole E. Spaulding, Pascal Bohleber, Michael J. Handley, Helene Hoffmann, Elena V. Korotkikh, Andrei V. Kurbatov, Christopher P. Loveluck, Sharon B. Sneed and Michael McCormick. 2017. "Next-Generation Ice Core Technology Reveals True Minimum Natural Levels of Lead $(\mathrm{Pb})$ in the Atmosphere: Insights from the Black Death." GeoHealth 1(4):211-219.

MPIDR and CGG. 2013. "MPIDR [Max Planck Institute for Demographic Research] and CGG [Chair for Geodesy and Geoinformatics, University of Rostock]: MPIDR Population History GIS Collection - Europe (partly based on (C) EuroGeographics for the ad- 
ministrative boundaries)." Rostock, https://censusmosaic.demog.berkeley.edu/ data/historical-gis-files, Data Accessed October 22, 2020.

Naidu, Suresh and Noam Yuchtman. 2013. "Coercive Contract Enforcement: Law and the Labor Market in Nineteenth Century Industrial Britain." American Economic Review 103(1):107-44.

Nipperdey, Thomas. 1961. Die Organisation der deutschen Parteien vor 1918. Düsseldorf, Germany: Droste Verlag.

North, Douglass C. and Robert Paul Thomas. 1973. The Rise of the Western World: A New Economic History. Cambridge, UK: Cambridge University Press.

Nüssli, Christos and Marc-Antoine Nüssli. 2008a. "Georeferenced Historical Vector Data 1300." https://www.euratlas.net/shop/maps_gis/gis_1300.html, Data Accessed on October 12, 2020.

Nüssli, Christos and Marc-Antoine Nüssli. 2008b. "Georeferenced Historical Vector Data 1900." http://www.euratlas.net/shop/maps_gis/gis_1900.html, Data Accessed through the Duke University Library, February 28, 2017.

Ogilvie, Sheilagh. 2014. Serfdom and the Institutional System in Early Modern Germany. In Serfdom and Slavery in the European Economy, 11th - 18th Centuries, ed. Simonetta Cavaciocchi. Florence, Italy: Firenze University Press pp. 33-58.

O'Loughlin, John. 2000. "Can King's Ecological Inference Method Answer a Social Scientific Puzzle: Who Voted for the Nazi Party in Weimar Germany?" Annals of the Association of American Geographers 90(3):592-601.

O’Loughlin, John. 2002. "The Electoral Geography of Weimar Germany: Exploratory Spatial Data Analyses (ESDA) of Protestant Support for the Nazi Party." Political Analysis 10(3):217-243. 
O'Loughlin, John, Colin Flint and Luc Anselin. 1994. "The Geography of the Nazi Vote: Context, Confession, and Class in the Reichstag Election of 1930." Annals of the Association of American Geographers 84(3):351-380.

Pamuk, Şevket. 2007. "The Black Death and the Origins of the 'Great Divergence' Across Europe, 1300-1600." European Review of Economic History 11(3):289-317.

Pepinsky, Thomas B., Sara Wallace Goodman and Conrad Ziller. 2020. "Does Proximity to Nazi Concentration Camps Make Germans Intolerant? Modeling Spatial Heterogeneity and Historical Persistence." Working Paper, Available at SSRN: https://ssrn.com/ abstract=3547321 or http://dx.doi.org/10.2139/ssrn.3547321, Accessed May 3, 2020.

Persson, Torsten and Guido Tabellini. 2000. Political Economics: Explaining Economic Policy. Cambridge, MA: The MIT Press.

Peters, Margaret. 2018. "Government Finance and Imposition of Serfdom After the Black Death." Working Paper, Available at SSRN: https://ssrn.com/abstract=3320807 or http://dx.doi.org/10.2139/ssrn.3320807, Accessed February 24, 2020.

Piketty, Thomas. 2014. Capital in the Twenty-First Century. Cambridge, MA: Harvard University Press.

Piketty, Thomas and Emmanuel Saez. 2014. "Inequality in the Long Run." Science 344(6186):838-843.

Postan, Michael M. 1966. Medieval Agrarian Society in its Prime: England. In The Cambridge Economic History of Europe: Volume 1, Agrarian Life of the Middle Ages, ed. Michael M. Postan. Cambridge, UK: Cambridge University Press pp. 549-632.

Reibel, Carl-Wilhelm. 2007. Handbuch der Reichstagswahlen 1890-1918: Bündnisse, Ergebnisse, Kandidaten [Handbook of Imperial Diet Elections 1890-1918: Coalitions, Results, 
Candidates]. Vol. 1 Düsseldorf, Germany: Droste Verlag.

Retallack, James. 2006. The German Right, 1860-1920: Political Limits of the Authoritarian Imagination. Toronto, Canada: University of Toronto Press.

Retallack, James N. 1988. Notables of the Right: The Conservative Party and Political Mobilization in Germany, 1876-1918. Boston, MA: Unwin Hyman.

Rich, Norman. 1992. Hitler's War Aims: Ideology, the Nazi State, and the Course of Expansion. New York, NY: WW Norton \& Company.

Roberts, Kenneth M. 2002. "Social Inequalities Without Class Cleavages in Latin America's Neoliberal Era." Studies in Comparative International Development 36(4):3-33.

Roche, Helen. 2013. Sparta's German Children: The Ideal of Ancient Sparta in the Royal Prussian Cadet Corps, 1818-1920, and in National Socialist Elite Schools (the Napolas), 1933-1945. Swansea, UK: Classical Press of Wales.

Rogowski, Ronald. 1989. Commerce and Coalitions: How Trade Affects Domestic Political Alignments. Princeton, NJ: Princeton University Press.

Rokkan, Stein. 1970. Citizens, Elections, Parties: Approaches to the Comparative Study of the Processes of Development. Oslo, Norway: Scandinavian University Books.

Rosenberg, Hans. 1958. Bureaucracy, Aristocracy, and Autocracy: The Prussian Experience. Cambridge, MA: Harvard University Press.

Rösener, Werner. 1996. The Agrarian Economy, 1300-1600. In Germany: A New Social and Economic History, Vol. 1: 1450-1630, ed. Bob Scribner. London, UK: Arnold pp. $63-84$.

Rueschemeyer, Dietrich, Evelyne Huber Stephens and John D. Stephens. 1992. Capitalist Development and Democracy. Chicago, IL: The University of Chicago Press.

Sabean, David. 1976. "The Communal Basis of Pre-1800 Peasant Uprisings in Western 
Europe." Comparative Politics 8(3):355-364.

Sabean, David Warren. 1984. Power in the Blood: Popular Culture and Village Discourse in Early Modern Germany. Cambridge, UK: Cambridge University Press.

Sachs, Jeffrey D. and Andrew M. Warner. 1997. "Sources of Slow Growth in African Economies." Journal of African Economies 6(3):335-376.

Satyanath, Shanker, Nico Voigtländer and Hans-Joachim Voth. 2017. "Bowling for Fascism: Social Capital and the Rise of the Nazi Party." Journal of Political Economy $125(2): 478-526$.

Scheidel, Walter. 2017. The Great Leveler. Violence and the Global History of Inequality from the Stone Age to the Present. Princeton, NJ: Princeton University Press.

Schmid, Boris V., Ulf Büntgen, W. Ryan Easterday, Christian Ginzler, Lars Walløe, Barbara Bramanti and Nils Chr. Stenseth. 2015. "Climate-Driven Introduction of the Black Death and Successive Plague Reintroductions into Europe." Proceedings of the National Academy of Sciences 112(10):3020-3025.

Scott, James C. 1972. Comparative Political Corruption. Englewood Cliffs, NJ: Prentice Hall.

Selb, Peter and Simon Munzert. 2018. "Examining a Most Likely Case for Strong Campaign Effects: Hitler's Speeches and the Rise of the Nazi Party, 1927-1933." American Political Science Review 112(4):1050-1066.

Sellars, Emily and Jennifer Alix-Garcia. 2018. "Labor Scarcity, Land Tenure, and Historical Legacy: Evidence from Mexico." Journal of Development Economics 135:504-516.

Siuda, Fabian and Uwe Sunde. 2019. "Disease and Demographic Development: The Legacy of the Black Death." Working Paper, May 8, 2019.

Snowden, Frank M. 2019. Epidemics and Society: From the Black Death to the Present. New 
Haven, CT: Yale University Press.

Sondheimer, Rachel Milstein and Donald P. Green. 2010. "Using Experiments to Estimate the Effects of Education on Voter Turnout." American Journal of Political Science $54(1): 174-189$.

Sperber, Jonathan. 1997. The Kaiser's Voters: Electors and Elections in Imperial Germany. Cambridge, UK: Cambridge University Press.

Stasavage, David. 2020. The Decline and the Rise of Democracy: A Global History from Anquity to Today. Princeton, NJ: Princeton University Press.

Stokes, Susan C., Thad Dunning, Marcelo Nazareno and Valeria Brusco. 2013. Brokers, Voters, and Clientelism: The Puzzle of Distributive Politics. Cambridge, UK: Cambridge University Press.

Strayer, Joseph. 1973. On the Medieval Origins of the Modern State. Princeton, NJ: Princeton University Press.

Streb, Jochen, Jörg Baten and Shuxi Yin. 2006. "Technological and Geographical Knowledge Spillover in the German Empire 1877-1918." The Economic History Review 59(2):347373.

Tarrow, Sidney. 2017. ““The World Changed Today!” Can We Recognize Critical Junctures When We See Them?" Qualitative and Multi-Method Research 15(1):9-11.

Thurner, Paul W., André Klima and Helmut Küchenhoff. 2015. "Agricultural Structure and the Rise of the Nazi Party Reconsidered." Political Geography 44:50 - 63.

Tilly, Charles. 1990. Coercion, Capital, and European States, 990-1990. Boston, MA: Basil Blackwell.

Uslaner, Eric M. 2008. Corruption, Inequality, and the Rule of Law. Cambridge, UK: Cambridge University Press. 
Vogler, Jan P. 2019. "Imperial Rule, the Imposition of Bureaucratic Institutions, and their Long-Term Legacies." World Politics 71(4):806-863.

Voigtländer, Nico and Hans-Joachim Voth. 2013. "The Three Horsemen of Riches: Plague, War, and Urbanization in Early Modern Europe." Review of Economic Studies 80(2):774-811.

Wahl, Fabian. 2016a. "Does Medieval Trade Still Matter? Historical Trade Centers, Agglomeration and Contemporary Economic Development." Regional Science and Urban Economics 60:50-60.

Wahl, Fabian. 2016b. "Participative Political Institutions in Pre-Modern Europe: Introducing a New Database." Historical Methods: A Journal of Quantitative and Interdisciplinary History 49(2):67-79.

Wahl, Fabian. 2019. "Political Participation and Economic Development. Evidence from the Rise of Participative Political Institutions in the Late Medieval German Lands." European Review of Economic History 23(2):193-213.

Weber, Max. 1946. From Max Weber: Essays in Sociology. New York, NY: Oxford University Press.

Willems, Emilio. 1986. A Way of Life and Death: Three Centuries of Prussian-German Militarism - An Anthropological Approach. Nashville, TN: Vanderbilt University Press.

Wilson, Peter. 2003. German Armies: War and German Society, 1648-1806. London, UK: UCL Press/Taylor \& Francis.

Wilson, Peter H. 2016. Heart of Europe: A History of the Holy Roman Empire. Cambridge, MA: Harvard University Press.

Yue, Ricci P.H., Harry F. Lee and Connor Y.H. Wu. 2017. "Trade Routes and Plague Transmission in Pre-Industrial Europe." Scientific Reports 7(1):1-10. 
Ziblatt, Daniel. 2008. "Does Landholding Inequality Block Democratization?: A Test of the "Bread and Democracy" Thesis and the Case of Prussia." World Politics 60(4):610641.

Ziblatt, Daniel. 2009. "Shaping Democratic Practice and the Causes of Electoral Fraud: The Case of Nineteenth-Century Germany." American Political Science Review 103(1):121.

Zins, H. 1959. "Aspects of the Peasant Rising in East Prussia in 1525." The Slavonic and East European Review 38(90):178-187. 


\section{A Appendix}

This appendix includes additional empirical evidence and further discussions of claims that were made in the main body of the paper. In subsection A.1, we provide summary statistics for electoral districts in Imperial Germany. In subsection A.2, we show the results for two outcome variables in Imperial Germany when using Tobit models instead of OLS regression. In subsection A.3, we include additional control variables that were not in the main analysis because they may be subject to post-treatment bias. In subsection A.4, we provide a second empirical response to the argument that the Reformation could be responsible for the observed patterns in nineteenth-century Germany. In subsection A.5, we exclude a number of observations when calculating the BDEI score. In subsection A.6, we provide results for a measure of land inequality conditional on the relevance of agriculture versus other sectors of the economy. In subsection A.7, we use the timing of Black Death outbreaks as an instrument in a two-stage least squares regression to more effectively isolate the exogenous component of local Black Death intensities. In subsection A.8, we show results when using dummy variables instead of absolute distances to geographic features. In subsection A.9, we account for historical information asymmetries in agricultural production potential. In subsection A.10, we introduce quasi-random spatial fixed effects to address the possibility of unobserved regional heterogeneity. In subsection A.11, we use two alternative datasets of Black Death outbreaks to check if our results hold when using a different set of underlying observations. In subsection A.12, we introduce spatial fixed effects based on pre-treatment administrative units as an alternative method of accounting for unobserved regional heterogeneity in initial conditions. In subsection A.13, we extend our main analysis to (1) all conservative parties in the 1871 election, (2) all liberal/moderate parties in the 1871 election, and (3) Conservative Party vote shares in the subsequent 1874 election. In subsection A.14, we take population 
sizes into account when computing the BDEI score. In subsection A.15, we manually limit the observations taken into account when computing the BDEI score to those that immediately neighbor Germany. In subsection A.16, we account for agricultural potential as a possible (co-)determinant of socioeconomic structures. In subsection A.17, we provide summary statistics for Weimar Germany's electoral districts. In subsection A.18, we show the results for both outcome variables in Weimar Germany when using Tobit models instead of OLS regression. In subsection A.19, we use an alternative dataset to analyze the relationship of Black Death intensities and NSDAP vote shares. In subsection A.20, we provide summary statistics for towns in pre-Reformation Germany. In subsection A.21, we measure the "occurrence of" rather than "changes in" participative elections in pre-Reformation Germany. In subsection A.22, we provide summary statistics for early nineteenth-century Prussia. In subsection A.23, we show the results for both outcome variables in early nineteenth-century Prussia when using Tobit models instead of OLS regression. In subsection A.24, we discuss some possible substantive issues related to the empirical design, including (1) our focus on the 1347-1351 pandemic, (2) possible divergence in pre-existing political-economic institutions, and (3) the non-inclusion of the Free Conservative Party in our main analysis. Finally, in subsection A.25, we provide a detailed qualitative illustration of the mechanisms leading to differential political-economic equilibria that we suggested in our theory.

\section{A.1 Imperial Germany: Descriptive Summary Statistics}

Table A.1 shows descriptive summary statistics for electoral districts in Imperial Germany. 
Table A1: Descriptive Statistics: Imperial Germany

\begin{tabular}{|c|c|c|c|c|c|c|c|c|}
\hline Variable & $\mathbf{n}$ & Min & $\mathrm{q}_{1}$ & $\overline{\mathbf{x}}$ & $\widetilde{\mathbf{x}}$ & $\mathbf{q}_{3}$ & $\operatorname{Max}$ & IQR \\
\hline BDEI Score v1 & 397 & -2.57 & -0.67 & 0.00 & 0.21 & 0.86 & 1.39 & 1.54 \\
\hline BDEI Score v2 & 397 & -2.24 & -0.74 & 0.00 & 0.16 & 0.86 & 1.45 & 1.61 \\
\hline BDEI Score v3 & 397 & -2.11 & -0.76 & 0.00 & 0.17 & 0.85 & 1.49 & 1.61 \\
\hline BDEI Score v4 & 397 & -2.07 & -0.78 & 0.00 & 0.28 & 0.82 & 1.45 & 1.59 \\
\hline BDEI Score v5 & 397 & -2.05 & -0.76 & 0.00 & 0.37 & 0.82 & 1.34 & 1.58 \\
\hline Landholding Inequality (Gini) & 397 & 0.46 & 0.63 & 0.73 & 0.73 & 0.83 & 0.95 & 0.20 \\
\hline Conservative Party Vote Share (1871) & 382 & 0.00 & 0.00 & 0.16 & 0.00 & 0.29 & 1.00 & 0.29 \\
\hline Net Electoral Disputes (1871-1912) & 397 & 0.00 & 1.00 & 2.39 & 2.00 & 3.00 & 10.00 & 2.00 \\
\hline Urban Density (Standardized) (1300) & 397 & -3.06 & -0.38 & 0.00 & 0.26 & 0.75 & 1.20 & 1.13 \\
\hline Distance to the Nearest Major Port $(\mathrm{km})$ & 397 & 0.00 & 59.32 & 164.59 & 141.50 & 255.86 & 475.98 & 196.54 \\
\hline Distance to the Nearest Medieval Trade City $(\mathrm{km})$ & 397 & 0.00 & 34.54 & 94.92 & 63.12 & 116.21 & 477.05 & 81.68 \\
\hline Distance to the Ocean $(\mathrm{km})$ & 397 & 0.00 & 91.05 & 222.98 & 217.09 & 346.25 & 582.91 & 255.20 \\
\hline Distance to the Nearest Large River (km) & 397 & 0.00 & 0.00 & 34.37 & 20.45 & 55.72 & 157.30 & 55.72 \\
\hline Elevation & 397 & -15.00 & 65.00 & 221.51 & 158.00 & 330.00 & 979.00 & 265.00 \\
\hline Population Size (in 1000s) & 391 & 32.06 & 91.67 & 103.30 & 104.40 & 114.34 & 208.00 & 22.67 \\
\hline Prussia & 397 & 0.00 & 0.00 & 0.59 & 1.00 & 1.00 & 1.00 & 1.00 \\
\hline Proportion Catholic (1871) & 397 & 0.00 & 0.02 & 0.37 & 0.23 & 0.73 & 1.00 & 0.71 \\
\hline Dummy Major Port $(\leq 10 \mathrm{~km})$ & 397 & 0.00 & 0.00 & 0.08 & 0.00 & 0.00 & 1.00 & 0.00 \\
\hline Dummy Trade City $(\leq 10 \mathrm{~km})$ & 397 & 0.00 & 0.00 & 0.11 & 0.00 & 0.00 & 1.00 & 0.00 \\
\hline Dummy Ocean $(\leq 10 \mathrm{~km})$ & 397 & 0.00 & 0.00 & 0.11 & 0.00 & 0.00 & 1.00 & 0.00 \\
\hline Dummy River $(\leq 10 \mathrm{~km})$ & 397 & 0.00 & 0.00 & 0.39 & 0.00 & 1.00 & 1.00 & 1.00 \\
\hline Caloric Variability & 397 & 6.21 & 46.85 & 154.39 & 124.86 & 219.77 & 1449.68 & 172.93 \\
\hline Vote Share of All Liberal Parties (1871) & 380 & 0.00 & 0.43 & 0.66 & 0.70 & 1.00 & 1.00 & 0.57 \\
\hline Vote Share of All Conservative Parties (1871) & 382 & 0.00 & 0.00 & 0.25 & 0.11 & 0.48 & 1.00 & 0.48 \\
\hline Conservative Party Vote Share (1874) & 397 & 0.00 & 0.00 & 0.09 & 0.00 & 0.06 & 0.77 & 0.06 \\
\hline Caloric Potential & 397 & 6416.96 & 8673.28 & 9022.08 & 9078.08 & 9408.96 & 10109.44 & 735.68 \\
\hline BDEI Score v1 (Alternative Version) & 397 & -2.66 & -0.72 & 0.00 & 0.17 & 0.78 & 1.60 & 1.50 \\
\hline BDEI Score v2 (Alternative Version) & 397 & -2.42 & -0.75 & 0.00 & 0.22 & 0.77 & 1.66 & 1.52 \\
\hline BDEI Score v3 (Alternative Version) & 397 & -2.31 & -0.68 & 0.00 & 0.28 & 0.77 & 1.63 & 1.45 \\
\hline BDEI Score v4 (Alternative Version) & 397 & -2.24 & -0.67 & 0.00 & 0.36 & 0.73 & 1.54 & 1.40 \\
\hline BDEI Score v5 (Alternative Version) & 397 & -2.17 & -0.70 & 0.00 & 0.44 & 0.76 & 1.41 & 1.46 \\
\hline BDEI Score v1 (2SLS) & 397 & -2.62 & -0.69 & 0.00 & 0.22 & 0.86 & 1.34 & 1.56 \\
\hline BDEI Score v2 (2SLS) & 397 & -2.28 & -0.77 & 0.00 & 0.19 & 0.88 & 1.38 & 1.65 \\
\hline BDEI Score v3 (2SLS) & 397 & -2.13 & -0.75 & 0.00 & 0.20 & 0.88 & 1.36 & 1.64 \\
\hline BDEI Score v4 (2SLS) & 397 & -2.06 & -0.78 & 0.00 & 0.28 & 0.88 & 1.32 & 1.66 \\
\hline BDEI Score v5 (2SLS) & 397 & -2.00 & -0.82 & 0.00 & 0.33 & 0.83 & 1.24 & 1.65 \\
\hline BDEI Score v1 (Alt. Data 1) (Büntgen et al.) & 397 & -2.71 & -0.73 & 0.00 & 0.16 & 0.82 & 1.53 & 1.55 \\
\hline BDEI Score v2 (Alt. Data 1) (Büntgen et al.) & 397 & -2.33 & -0.81 & 0.00 & 0.11 & 0.82 & 1.72 & 1.62 \\
\hline BDEI Score v3 (Alt. Data 1) (Büntgen et al.) & 397 & -2.13 & -0.84 & 0.00 & 0.08 & 0.81 & 1.88 & 1.65 \\
\hline BDEI Score v4 (Alt. Data 1) (Büntgen et al.) & 397 & -2.01 & -0.87 & 0.00 & 0.06 & 0.79 & 2.02 & 1.66 \\
\hline BDEI Score v5 (Alt. Data 1) (Büntgen et al.) & 397 & -1.96 & -0.88 & 0.00 & 0.11 & 0.76 & 2.16 & 1.64 \\
\hline BDEI Score v1 (Alt. Data 2) (Schmid et al.) & 397 & -2.86 & -0.67 & 0.00 & 0.22 & 0.81 & 1.37 & 1.48 \\
\hline BDEI Score v2 (Alt. Data 2) (Schmid et al.) & 397 & -2.45 & -0.76 & 0.00 & 0.13 & 0.84 & 1.53 & 1.60 \\
\hline BDEI Score v3 (Alt. Data 2) (Schmid et al.) & 397 & -2.19 & -0.77 & 0.00 & 0.09 & 0.83 & 1.66 & 1.60 \\
\hline BDEI Score v4 (Alt. Data 2) (Schmid et al.) & 397 & -2.03 & -0.83 & 0.00 & 0.09 & 0.84 & 1.76 & 1.67 \\
\hline BDEI Score v5 (Alt. Data 2) (Schmid et al.) & 397 & -1.92 & -0.90 & 0.00 & 0.06 & 0.84 & 1.86 & 1.74 \\
\hline BDEI Score v1 (Weighted by Population) & 397 & -2.58 & -0.71 & 0.00 & 0.16 & 0.86 & 1.56 & 1.57 \\
\hline BDEI Score v2 (Weighted by Population) & 397 & -2.23 & -0.78 & 0.00 & 0.17 & 0.87 & 1.72 & 1.65 \\
\hline BDEI Score v3 (Weighted by Population) & 397 & -2.11 & -0.77 & 0.00 & 0.19 & 0.84 & 1.83 & 1.61 \\
\hline BDEI Score v4 (Weighted by Population) & 397 & -2.09 & -0.76 & 0.00 & 0.31 & 0.76 & 1.83 & 1.51 \\
\hline BDEI Score v5 (Weighted by Population) & 397 & -2.07 & -0.69 & 0.00 & 0.36 & 0.78 & 1.69 & 1.47 \\
\hline BDEI Score v1 (Neighboring Regions Only) & 397 & -2.58 & -0.70 & 0.00 & 0.26 & 0.79 & 1.39 & 1.50 \\
\hline BDEI Score v2 (Neighboring Regions Only) & 397 & -2.38 & -0.65 & 0.00 & 0.35 & 0.79 & 1.31 & 1.44 \\
\hline BDEI Score v3 (Neighboring Regions Only) & 397 & -2.25 & -0.68 & 0.00 & 0.44 & 0.81 & 1.09 & 1.48 \\
\hline BDEI Score v4 (Neighboring Regions Only) & 397 & -2.09 & -0.70 & 0.00 & 0.46 & 0.72 & 1.32 & 1.42 \\
\hline BDEI Score v5 (Neighboring Regions Only) & 397 & -1.94 & -0.74 & 0.00 & 0.44 & 0.64 & 1.61 & 1.39 \\
\hline
\end{tabular}




\section{A.2 Imperial Germany: Tobit Models as an Alternative Specifi- cation}

In our main empirical analysis we use OLS regression to estimate the impact of the BDEI score on land inequality and Conservative Party vote share. Because these two outcome variables are truncated, i.e. both have an upper and lower bound, we also use Tobit models as an alternative empirical specification.

Table A2 shows the results with respect to land inequality when using Tobit models. Furthermore, Table A3 shows the results with respect to Conservative Party vote share when using Tobit models. In both cases, the direction, magnitude, and significance of the coefficients do not change in a way that would alter our previous interpretation. 
Table A2: Land Inequality (Tobit)

\begin{tabular}{|c|c|c|c|c|c|c|c|c|c|c|}
\hline & \multicolumn{10}{|c|}{ Dependent variable: } \\
\hline & & & & & Land I & uality (Gini) & & & & \\
\hline & $(1)$ & $(2)$ & $(3)$ & $(4)$ & $(5)$ & $(6)$ & $(7)$ & $(8)$ & $(9)$ & $(10)$ \\
\hline BDEI Score v1 & $\begin{array}{c}-0.061^{* * *} \\
(0.005)\end{array}$ & & & & & $\begin{array}{c}-0.053^{* * *} \\
(0.007)\end{array}$ & & & & \\
\hline BDEI Score v2 & & $\begin{array}{c}-0.061^{* * *} \\
(0.005)\end{array}$ & & & & & $\begin{array}{c}-0.049^{* * *} \\
(0.007)\end{array}$ & & & \\
\hline BDEI Score v3 & & & $\begin{array}{c}-0.059^{* * *} \\
(0.005)\end{array}$ & & & & & $\begin{array}{c}-0.048^{* * *} \\
(0.007)\end{array}$ & & \\
\hline BDEI Score v4 & & & & $\begin{array}{c}-0.057^{* * *} \\
(0.005)\end{array}$ & & & & & $\begin{array}{c}-0.046^{* * *} \\
(0.007)\end{array}$ & \\
\hline BDEI Score v5 & & & & & $\begin{array}{c}-0.053^{* * *} \\
(0.005)\end{array}$ & & & & & $\begin{array}{c}-0.042^{* * *} \\
\quad(0.007)\end{array}$ \\
\hline Urb. Dens. 1300 & & & & & & $\begin{array}{l}-0.014 \\
(0.010)\end{array}$ & $\begin{array}{c}-0.017^{*} \\
(0.010)\end{array}$ & $\begin{array}{c}-0.019^{*} \\
(0.010)\end{array}$ & $\begin{array}{c}-0.019^{*} \\
(0.010)\end{array}$ & $\begin{array}{c}-0.021^{*} \\
(0.011)\end{array}$ \\
\hline Dist. Maj. Port & & & & & & $\begin{array}{c}-0.001^{* * *} \\
(0.0001)\end{array}$ & $\begin{array}{c}-0.001^{* * *} \\
(0.0001)\end{array}$ & $\begin{array}{c}-0.001^{* * *} \\
(0.0001)\end{array}$ & $\begin{array}{c}-0.001^{* * *} \\
(0.0001)\end{array}$ & $\begin{array}{c}-0.001^{* * *} \\
(0.0001)\end{array}$ \\
\hline Dist. Trade City & & & & & & $\begin{array}{c}-0.0002^{* * *} \\
(0.0001)\end{array}$ & $\begin{array}{c}-0.0002^{* * *} \\
(0.0001)\end{array}$ & $\begin{array}{c}-0.0002^{* *} \\
(0.0001)\end{array}$ & $\begin{array}{c}-0.0001^{* *} \\
(0.0001)\end{array}$ & $\begin{array}{c}-0.0001^{* *} \\
(0.0001)\end{array}$ \\
\hline Dist. Ocean & & & & & & $\begin{array}{c}0.0001 \\
(0.0001)\end{array}$ & $\begin{array}{c}0.0001 \\
(0.0001)\end{array}$ & $\begin{array}{c}0.0001 \\
(0.0001)\end{array}$ & $\begin{array}{c}0.0001 \\
(0.0001)\end{array}$ & $\begin{array}{c}0.0002 \\
(0.0001)\end{array}$ \\
\hline Dist. River & & & & & & $\begin{array}{l}0.00000 \\
(0.0001)\end{array}$ & $\begin{array}{c}0.00001 \\
(0.0001)\end{array}$ & $\begin{array}{l}0.00002 \\
(0.0001)\end{array}$ & $\begin{array}{l}0.00003 \\
(0.0001)\end{array}$ & $\begin{array}{c}0.0001 \\
(0.0001)\end{array}$ \\
\hline Elevation & & & & & & $\begin{array}{c}-0.0001^{* * *} \\
(0.00003)\end{array}$ & $\begin{array}{c}-0.0001^{* * *} \\
(0.00003)\end{array}$ & $\begin{array}{c}-0.0001^{* * *} \\
(0.00003)\end{array}$ & $\begin{array}{c}-0.0001^{* * *} \\
(0.00003)\end{array}$ & $\begin{array}{c}-0.0002^{* * *} \\
(0.00003)\end{array}$ \\
\hline Constant & $\begin{array}{c}0.726^{* * *} \\
(0.005)\end{array}$ & $\begin{array}{c}0.726^{* * *} \\
(0.005)\end{array}$ & $\begin{array}{c}0.726^{* * *} \\
(0.005) \\
\end{array}$ & $\begin{array}{c}0.726^{* * *} \\
(0.005) \\
\end{array}$ & $\begin{array}{c}0.726^{* * *} \\
(0.005) \\
\end{array}$ & $\begin{array}{c}0.844^{* * *} \\
(0.012) \\
\end{array}$ & $\begin{array}{c}0.844^{* * *} \\
(0.012) \\
\end{array}$ & $\begin{array}{c}0.843^{* * *} \\
(0.012) \\
\end{array}$ & $\begin{array}{c}0.843^{* * *} \\
(0.012) \\
\end{array}$ & $\begin{array}{c}0.842^{* * *} \\
(0.012)\end{array}$ \\
\hline Observations & 397 & 397 & 397 & 397 & 397 & 397 & 397 & 397 & 397 & 397 \\
\hline Log Likelihood & 338.781 & 337.299 & 334.267 & 328.939 & 321.554 & 481.971 & 482.407 & 480.764 & 477.418 & 472.479 \\
\hline
\end{tabular}


Table A3: Conservative Party Vote Share (Tobit)

\begin{tabular}{|c|c|c|c|c|c|c|c|c|c|c|}
\hline & \multicolumn{10}{|c|}{ Dependent variable: } \\
\hline & \multicolumn{10}{|c|}{ Conservative Party Vote Share } \\
\hline & $(1)$ & $(2)$ & $(3)$ & $(4)$ & $(5)$ & $(6)$ & $(7)$ & $(8)$ & $(9)$ & $(10)$ \\
\hline BDEI Score v1 & $\begin{array}{c}-0.229^{* * *} \\
(0.026)\end{array}$ & & & & & $\begin{array}{c}-0.306^{* * *} \\
(0.052)\end{array}$ & & & & \\
\hline BDEI Score v2 & & $\begin{array}{c}-0.230^{* * *} \\
(0.026)\end{array}$ & & & & & $\begin{array}{c}-0.283^{* * *} \\
(0.047)\end{array}$ & & & \\
\hline BDEI Score v3 & & & $\begin{array}{c}-0.227^{* * *} \\
(0.026)\end{array}$ & & & & & $\begin{array}{c}-0.279^{* * *} \\
(0.047)\end{array}$ & & \\
\hline BDEI Score v4 & & & & $\begin{array}{c}-0.220^{* * *} \\
(0.026)\end{array}$ & & & & & $\begin{array}{c}-0.290^{* * *} \\
(0.048)\end{array}$ & \\
\hline BDEI Score v5 & & & & & $\begin{array}{c}-0.210^{* * *} \\
(0.026)\end{array}$ & & & & & $\begin{array}{c}-0.307^{* * *} \\
(0.051)\end{array}$ \\
\hline Urb. Dens. 1300 & & & & & & $\begin{array}{c}0.188^{* * *} \\
(0.064)\end{array}$ & $\begin{array}{c}0.166^{* * *} \\
(0.062)\end{array}$ & $\begin{array}{c}0.167^{* * *} \\
(0.062)\end{array}$ & $\begin{array}{c}0.190^{* * *} \\
(0.064)\end{array}$ & $\begin{array}{c}0.223^{* * *} \\
(0.067)\end{array}$ \\
\hline Dist. Maj. Port & & & & & & $\begin{array}{c}-0.0001 \\
(0.001)\end{array}$ & $\begin{array}{c}-0.0001 \\
(0.001)\end{array}$ & $\begin{array}{c}-0.0001 \\
(0.001)\end{array}$ & $\begin{array}{c}-0.00004 \\
(0.001)\end{array}$ & $\begin{array}{c}0.0001 \\
(0.001)\end{array}$ \\
\hline Dist. Trade City & & & & & & $\begin{array}{c}0.0005 \\
(0.0004)\end{array}$ & $\begin{array}{c}0.001 \\
(0.0004)\end{array}$ & $\begin{array}{c}0.001 \\
(0.0004)\end{array}$ & $\begin{array}{c}0.001^{*} \\
(0.0004)\end{array}$ & $\begin{array}{c}0.001^{*} \\
(0.0004)\end{array}$ \\
\hline Dist. Ocean & & & & & & $\begin{array}{c}-0.001^{*} \\
(0.001)\end{array}$ & $\begin{array}{c}-0.001^{*} \\
(0.001)\end{array}$ & $\begin{array}{c}-0.001^{*} \\
(0.001)\end{array}$ & $\begin{array}{c}-0.001^{*} \\
(0.001)\end{array}$ & $\begin{array}{c}-0.002^{* *} \\
(0.001)\end{array}$ \\
\hline Dist. River & & & & & & $\begin{array}{l}-0.001 \\
(0.001)\end{array}$ & $\begin{array}{l}-0.001 \\
(0.001)\end{array}$ & $\begin{array}{l}-0.001 \\
(0.001)\end{array}$ & $\begin{array}{l}-0.001 \\
(0.001)\end{array}$ & $\begin{array}{l}-0.001 \\
(0.001)\end{array}$ \\
\hline Elevation & & & & & & $\begin{array}{c}0.0001 \\
(0.0002)\end{array}$ & $\begin{array}{c}0.0001 \\
(0.0002)\end{array}$ & $\begin{array}{c}0.0001 \\
(0.0002)\end{array}$ & $\begin{array}{c}0.0001 \\
(0.0002)\end{array}$ & $\begin{array}{c}0.0001 \\
(0.0002)\end{array}$ \\
\hline Constant & $\begin{array}{c}-0.080^{* * *} \\
(0.031) \\
\end{array}$ & $\begin{array}{c}-0.081^{* * *} \\
(0.031) \\
\end{array}$ & $\begin{array}{c}-0.081^{* * *} \\
(0.031) \\
\end{array}$ & $\begin{array}{c}-0.080^{* * *} \\
(0.031) \\
\end{array}$ & $\begin{array}{c}-0.079^{* *} \\
(0.031) \\
\end{array}$ & $\begin{array}{l}0.147^{*} \\
(0.077) \\
\end{array}$ & $\begin{array}{l}0.140^{*} \\
(0.076) \\
\end{array}$ & $\begin{array}{l}0.144^{*} \\
(0.076) \\
\end{array}$ & $\begin{array}{c}0.160^{* *} \\
(0.077) \\
\end{array}$ & $\begin{array}{c}0.185^{* *} \\
(0.079) \\
\end{array}$ \\
\hline Observations & 382 & 382 & 382 & 382 & 382 & 382 & 382 & 382 & 382 & 382 \\
\hline Log Likelihood & -213.050 & -213.422 & -214.693 & -216.896 & -219.913 & -184.399 & -184.203 & -184.126 & -183.781 & -183.522 \\
\hline
\end{tabular}




\section{A.3 Imperial Germany: Extension 1 - Including Additional Co- variates}

In the main body of the paper we did not include any political or social control variables specific to nineteenth-century Germany due to the possibility of introducing post-treatment bias. Nevertheless, in a limited number of cases, the inclusion of further controls from this time period may be justified due to their substantive or technical relevance. We elaborate on two specific instances below. Importantly, these results can only be seen as complementary to our main results, not as a substitute.

First, while most electoral districts were similar in population size (as they were based on the 1864 census), some were above or below the average, for example in cases in which migratory movements after 1864 had changed district sizes. Therefore, we control for the population size of electoral districts.

Second, historians often differentiate between Prussian and "non-Prussian" Imperial Germany, especially when it comes to electoral outcomes (Sperber, 1997, 29). Doing so would also be important for a substantive political reason: The Conservative Party originated in Prussia and did not have a sufficient party organization in many other parts of the country. In fact, in many areas, no comparable (conservatively-oriented) party was a viable competitor in elections. Of course, this is clearly linked to differing socioeconomic conditions and

political norms/traditions that also were a long-term outcome of variations in Black Death intensities. Nevertheless, including a control variable for Prussia may be considered a more "conservative" empirical strategy.

The results we obtain can be found in Table A4. For the most part, they confirm previous findings and are in line with our theory. It is noticeable that Prussian districts experienced a significantly higher number of electoral disputes between 1871 and 1912. 
Table A4: Extension 1: Including Additional Covariates

\begin{tabular}{|c|c|c|c|c|c|c|c|c|c|}
\hline & \multicolumn{9}{|c|}{ Dependent variable: } \\
\hline & \multirow{2}{*}{\multicolumn{3}{|c|}{$\begin{array}{l}\text { Land Inequality (Gini) } \\
\qquad O L S\end{array}$}} & \multirow{2}{*}{\multicolumn{3}{|c|}{$\begin{array}{c}\text { Conservative Party Vote Share } \\
\qquad O L S\end{array}$}} & \multirow{2}{*}{\multicolumn{3}{|c|}{$\begin{array}{l}\text { Net Electoral Disputes } \\
\text { glm: quasipoisson } \\
\text { link }=\log \end{array}$}} \\
\hline & & & & & & & & & \\
\hline & $(1)$ & $(2)$ & $(3)$ & $(4)$ & $(5)$ & (6) & $(7)$ & $(8)$ & (9) \\
\hline BDEI Score v1 & $\begin{array}{c}-0.050^{* * *} \\
(0.015)\end{array}$ & & & $\begin{array}{c}-0.142^{* * *} \\
(0.029)\end{array}$ & & & $\begin{array}{c}-0.318^{* *} \\
(0.124)\end{array}$ & & \\
\hline BDEI Score v3 & & $\begin{array}{c}-0.045^{* * *} \\
(0.013)\end{array}$ & & & $\begin{array}{c}-0.129^{* * *} \\
(0.026)\end{array}$ & & & $\begin{array}{c}-0.290^{* *} \\
(0.113)\end{array}$ & \\
\hline BDEI Score v5 & & & $\begin{array}{c}-0.039^{* * *} \\
(0.013)\end{array}$ & & & $\begin{array}{c}-0.131^{* * *} \\
(0.030)\end{array}$ & & & $\begin{array}{c}-0.292^{* *} \\
(0.120)\end{array}$ \\
\hline Population & $\begin{array}{c}0.0002 \\
(0.0002)\end{array}$ & $\begin{array}{c}0.0002 \\
(0.0002)\end{array}$ & $\begin{array}{c}0.0002 \\
(0.0002)\end{array}$ & $\begin{array}{l}-0.001 \\
(0.001)\end{array}$ & $\begin{array}{l}-0.001 \\
(0.001)\end{array}$ & $\begin{array}{l}-0.001 \\
(0.001)\end{array}$ & $\begin{array}{c}0.006^{* * *} \\
(0.002)\end{array}$ & $\begin{array}{c}0.006^{* * *} \\
(0.002)\end{array}$ & $\begin{array}{c}0.006^{* * *} \\
(0.002)\end{array}$ \\
\hline Prussia & $\begin{array}{c}0.001 \\
(0.018)\end{array}$ & $\begin{array}{c}0.001 \\
(0.018)\end{array}$ & $\begin{array}{c}-0.0001 \\
(0.020)\end{array}$ & $\begin{array}{c}0.141^{* * *} \\
(0.042)\end{array}$ & $\begin{array}{c}0.140^{* * *} \\
(0.042)\end{array}$ & $\begin{array}{c}0.131^{* * *} \\
(0.045)\end{array}$ & $\begin{array}{c}0.290^{* * *} \\
(0.103)\end{array}$ & $\begin{array}{c}0.290^{* * *} \\
(0.102)\end{array}$ & $\begin{array}{c}0.275^{* * *} \\
(0.102)\end{array}$ \\
\hline Urb. Dens. 1300 & $\begin{array}{l}-0.018 \\
(0.018)\end{array}$ & $\begin{array}{l}-0.023 \\
(0.018)\end{array}$ & $\begin{array}{l}-0.027 \\
(0.018)\end{array}$ & $\begin{array}{c}0.159^{* * *} \\
(0.058)\end{array}$ & $\begin{array}{c}0.148^{* * * *} \\
(0.054)\end{array}$ & $\begin{array}{c}0.157^{* * *} \\
(0.055)\end{array}$ & $\begin{array}{c}0.364^{* * *} \\
(0.141)\end{array}$ & $\begin{array}{c}0.342^{* *} \\
(0.137)\end{array}$ & $\begin{array}{c}0.367^{* *} \\
(0.146)\end{array}$ \\
\hline Dist. Maj. Port & $\begin{array}{c}-0.001^{* * *} \\
(0.0002)\end{array}$ & $\begin{array}{c}-0.001^{* * *} \\
(0.0002)\end{array}$ & $\begin{array}{c}-0.001^{* * *} \\
(0.0002)\end{array}$ & $\begin{array}{l}0.0004 \\
(0.001)\end{array}$ & $\begin{array}{c}0.0003 \\
(0.001)\end{array}$ & $\begin{array}{l}0.0004 \\
(0.001)\end{array}$ & $\begin{array}{c}0.001 \\
(0.001)\end{array}$ & $\begin{array}{c}0.001 \\
(0.001)\end{array}$ & $\begin{array}{c}0.001 \\
(0.001)\end{array}$ \\
\hline Dist. Trade City & $\begin{array}{l}-0.0002 \\
(0.0001)\end{array}$ & $\begin{array}{l}-0.0002 \\
(0.0001)\end{array}$ & $\begin{array}{l}-0.0002 \\
(0.0001)\end{array}$ & $\begin{array}{c}0.001^{* * * *} \\
(0.0002)\end{array}$ & $\begin{array}{l}0.001^{* * * *} \\
(0.0002)\end{array}$ & $\begin{array}{l}0.001 * * * \\
(0.0002)\end{array}$ & $\begin{array}{c}0.001 \\
(0.001)\end{array}$ & $\begin{array}{c}0.001 \\
(0.001)\end{array}$ & $\begin{array}{c}0.001 \\
(0.001)\end{array}$ \\
\hline Dist. Ocean & $\begin{array}{c}0.0001 \\
(0.0002)\end{array}$ & $\begin{array}{c}0.0001 \\
(0.0002)\end{array}$ & $\begin{array}{c}0.0002 \\
(0.0002)\end{array}$ & $\begin{array}{c}-0.0005 \\
(0.001)\end{array}$ & $\begin{array}{l}-0.001 \\
(0.001)\end{array}$ & $\begin{array}{l}-0.001 \\
(0.001)\end{array}$ & $\begin{array}{c}-0.002^{*} \\
(0.001)\end{array}$ & $\begin{array}{c}-0.002^{*} \\
(0.001)\end{array}$ & $\begin{array}{c}-0.002^{*} \\
(0.001)\end{array}$ \\
\hline Dist. River & $\begin{array}{l}0.00001 \\
(0.0001)\end{array}$ & $\begin{array}{c}0.00002 \\
(0.0001)\end{array}$ & $\begin{array}{c}0.0001 \\
(0.0002)\end{array}$ & $\begin{array}{c}-0.001 \\
(0.0004)\end{array}$ & $\begin{array}{c}-0.001 \\
(0.0004)\end{array}$ & $\begin{array}{c}-0.001 \\
(0.0004)\end{array}$ & $\begin{array}{c}0.001 \\
(0.001)\end{array}$ & $\begin{array}{c}0.001 \\
(0.001)\end{array}$ & $\begin{array}{c}0.001 \\
(0.001)\end{array}$ \\
\hline Elevation & $\begin{array}{c}-0.0001^{* * *} \\
(0.00005)\end{array}$ & $\begin{array}{c}-0.0001^{* * *} \\
(0.00005)\end{array}$ & $\begin{array}{c}-0.0001^{* * *} \\
(0.00005)\end{array}$ & $\begin{array}{l}0.00005 \\
(0.0001)\end{array}$ & $\begin{array}{c}0.0001 \\
(0.0001)\end{array}$ & $\begin{array}{c}0.00005 \\
(0.0001)\end{array}$ & $\begin{array}{c}0.001 \\
(0.0004)\end{array}$ & $\begin{array}{c}0.001 \\
(0.0004)\end{array}$ & $\begin{array}{c}0.0005 \\
(0.0004)\end{array}$ \\
\hline Constant & $\begin{array}{c}0.817^{* * *} \\
(0.042) \\
\end{array}$ & $\begin{array}{c}0.816^{* * *} \\
(0.043) \\
\end{array}$ & $\begin{array}{c}0.817^{* * *} \\
(0.045) \\
\end{array}$ & $\begin{array}{c}0.120 \\
(0.086) \\
\end{array}$ & $\begin{array}{c}0.119 \\
(0.086) \\
\end{array}$ & $\begin{array}{c}0.137 \\
(0.090) \\
\end{array}$ & $\begin{array}{c}0.147 \\
(0.334) \\
\end{array}$ & $\begin{array}{c}0.142 \\
(0.331) \\
\end{array}$ & $\begin{array}{c}0.190 \\
(0.346) \\
\end{array}$ \\
\hline Observations & 391 & 391 & 391 & 376 & 376 & 376 & 391 & 391 & 391 \\
\hline & 0.643 & 0.641 & 0.626 & 0.370 & 0.371 & 0.362 & & & \\
\hline Adjusted $\mathrm{R}^{2}$ & 0.634 & 0.632 & 0.617 & 0.355 & 0.355 & 0.346 & & & \\
\hline
\end{tabular}




\section{A.4 Imperial Germany: Extension 2 - Accounting for a Potential Effect of the Reformation}

In this extension, we provide a second empirical response to the argument that the Reformation - and not the Black Death - could be responsible for some of the variation we observe in Imperial Germany. During the Reformation, which began in 1517, many rulers of principalities across Germany turned away from the Catholic Church and towards Protestantism. Of course, the geographic pattern of the Reformation itself could partially be an outcome of variations in the intensity of the Black Death. While we have already demonstrated that key changes in political institutions at the town level predate the Reformation period, we include additional models that account for the proportion of an electoral district's population that is Catholic (based on data by Sperber (1997)). This control variable picks up differences between areas of Germany where Catholicism is strong and those where Protestantism is strong, which largely is a long-term outcome of the Reformation.

Table A5 shows the results of our extended analysis. The findings are again mostly in line with our theory and confirm previously obtained results. Only the effect of the BDEI score on net electoral disputes is no longer significant. However, as with extension 1 (subsection A.3), we caution the reader to carefully interpret these results due to the high likelihood of post-treatment bias. 
Table A5: Extension 2: Accounting for a Potential Effect of the Reformation

\begin{tabular}{|c|c|c|c|c|c|c|c|c|c|}
\hline & \multicolumn{9}{|c|}{ Dependent variable: } \\
\hline & \multirow{2}{*}{\multicolumn{3}{|c|}{$\begin{array}{l}\text { Land Inequality (Gini) } \\
\qquad O L S\end{array}$}} & \multirow{2}{*}{\multicolumn{3}{|c|}{$\begin{array}{c}\text { Conservative Party Vote Share } \\
\qquad L S S\end{array}$}} & \multirow{2}{*}{\multicolumn{3}{|c|}{$\begin{array}{l}\text { Net Electoral Disputes } \\
\text { glm: quasipoisson } \\
\text { link }=\log \end{array}$}} \\
\hline & & & & & & & & & \\
\hline & $(1)$ & $(2)$ & $(3)$ & $(4)$ & $(5)$ & $(6)$ & $(7)$ & $(8)$ & $(9)$ \\
\hline BDEI Score v1 & $\begin{array}{c}-0.034^{*} \\
(0.018)\end{array}$ & & & $\begin{array}{c}-0.088^{* *} \\
(0.037)\end{array}$ & & & $\begin{array}{c}0.011 \\
(0.138)\end{array}$ & & \\
\hline BDEI Score v3 & & $\begin{array}{c}-0.030^{*} \\
(0.016)\end{array}$ & & & $\begin{array}{c}-0.080^{* *} \\
(0.032)\end{array}$ & & & $\begin{array}{c}0.009 \\
(0.125)\end{array}$ & \\
\hline BDEI Score v5 & & & $\begin{array}{l}-0.018 \\
(0.015)\end{array}$ & & & $\begin{array}{c}-0.075^{* *} \\
(0.035)\end{array}$ & & & $\begin{array}{c}0.021 \\
(0.132)\end{array}$ \\
\hline Percent Catholic & $\begin{array}{c}-0.043^{*} \\
(0.024)\end{array}$ & $\begin{array}{c}-0.045^{*} \\
(0.024)\end{array}$ & $\begin{array}{c}-0.061^{* * *} \\
(0.023)\end{array}$ & $\begin{array}{c}-0.148^{* * *} \\
(0.055)\end{array}$ & $\begin{array}{c}-0.148^{* * *} \\
(0.054)\end{array}$ & $\begin{array}{c}-0.162^{* * *} \\
(0.054)\end{array}$ & $\begin{array}{c}-0.952^{* * *} \\
(0.203)\end{array}$ & $\begin{array}{c}-0.951^{* * *} \\
(0.201)\end{array}$ & $\begin{array}{c}-0.961^{* * *} \\
(0.201)\end{array}$ \\
\hline Population & $\begin{array}{c}0.0002 \\
(0.0002)\end{array}$ & $\begin{array}{c}0.0002 \\
(0.0002)\end{array}$ & $\begin{array}{c}0.0001 \\
(0.0002)\end{array}$ & $\begin{array}{c}-0.001^{*} \\
(0.001)\end{array}$ & $\begin{array}{c}-0.001^{*} \\
(0.001)\end{array}$ & $\begin{array}{c}-0.001^{*} \\
(0.001)\end{array}$ & $\begin{array}{l}0.004^{*} \\
(0.002)\end{array}$ & $\begin{array}{l}0.004^{*} \\
(0.002)\end{array}$ & $\begin{array}{l}0.004^{*} \\
(0.002)\end{array}$ \\
\hline Prussia & $\begin{array}{c}0.006 \\
(0.019)\end{array}$ & $\begin{array}{c}0.006 \\
(0.020)\end{array}$ & $\begin{array}{c}0.008 \\
(0.020)\end{array}$ & $\begin{array}{c}0.158^{* * *} \\
(0.044)\end{array}$ & $\begin{array}{c}0.157^{* * *} \\
(0.044)\end{array}$ & $\begin{array}{c}0.153^{* * *} \\
(0.047)\end{array}$ & $\begin{array}{c}0.385^{* * *} \\
(0.115)\end{array}$ & $\begin{array}{c}0.385^{* * *} \\
(0.114)\end{array}$ & $\begin{array}{c}0.389^{* * *} \\
(0.115)\end{array}$ \\
\hline Urb. Dens. 1300 & $\begin{array}{c}-0.041^{*} \\
(0.023)\end{array}$ & $\begin{array}{c}-0.046^{* *} \\
(0.022)\end{array}$ & $\begin{array}{c}-0.059^{* * *} \\
(0.022)\end{array}$ & $\begin{array}{c}0.080 \\
(0.065)\end{array}$ & $\begin{array}{c}0.073 \\
(0.059)\end{array}$ & $\begin{array}{c}0.070 \\
(0.059)\end{array}$ & $\begin{array}{l}-0.110 \\
(0.159)\end{array}$ & $\begin{array}{l}-0.108 \\
(0.152)\end{array}$ & $\begin{array}{l}-0.122 \\
(0.163)\end{array}$ \\
\hline Dist. Maj. Port & $\begin{array}{c}-0.001^{* * *} \\
(0.0002)\end{array}$ & $\begin{array}{c}-0.001^{* * *} \\
(0.0002)\end{array}$ & $\begin{array}{c}-0.001^{* * *} \\
(0.0002)\end{array}$ & $\begin{array}{c}0.0001 \\
(0.001)\end{array}$ & $\begin{array}{c}0.00004 \\
(0.001)\end{array}$ & $\begin{array}{c}0.00001 \\
(0.001)\end{array}$ & $\begin{array}{l}-0.001 \\
(0.001)\end{array}$ & $\begin{array}{l}-0.001 \\
(0.001)\end{array}$ & $\begin{array}{l}-0.001 \\
(0.001)\end{array}$ \\
\hline Dist. Trade City & $\begin{array}{c}-0.0002^{*} \\
(0.0001)\end{array}$ & $\begin{array}{c}-0.0002^{*} \\
(0.0001)\end{array}$ & $\begin{array}{l}-0.0002 \\
(0.0001)\end{array}$ & $\begin{array}{c}0.001^{* * *} \\
(0.0003)\end{array}$ & $\begin{array}{c}0.001^{* * *} \\
(0.0003)\end{array}$ & $\begin{array}{c}0.001^{* * *} \\
(0.0003)\end{array}$ & $\begin{array}{l}0.0002 \\
(0.001)\end{array}$ & $\begin{array}{l}0.0002 \\
(0.001)\end{array}$ & $\begin{array}{l}0.0002 \\
(0.001)\end{array}$ \\
\hline Dist. Ocean & $\begin{array}{c}0.0003 \\
(0.0002)\end{array}$ & $\begin{array}{c}0.0003 \\
(0.0002)\end{array}$ & $\begin{array}{c}0.0004^{* *} \\
(0.0002)\end{array}$ & $\begin{array}{c}-0.00004 \\
(0.001)\end{array}$ & $\begin{array}{c}-0.00005 \\
(0.001)\end{array}$ & $\begin{array}{c}-0.00003 \\
(0.001)\end{array}$ & $\begin{array}{c}0.001 \\
(0.001)\end{array}$ & $\begin{array}{c}0.001 \\
(0.001)\end{array}$ & $\begin{array}{c}0.001 \\
(0.001)\end{array}$ \\
\hline Dist. River & $\begin{array}{l}0.00005 \\
(0.0001)\end{array}$ & $\begin{array}{c}0.0001 \\
(0.0001)\end{array}$ & $\begin{array}{c}0.0001 \\
(0.0001)\end{array}$ & $\begin{array}{c}-0.001 \\
(0.0004)\end{array}$ & $\begin{array}{c}-0.001 \\
(0.0004)\end{array}$ & $\begin{array}{c}-0.001 \\
(0.0004)\end{array}$ & $\begin{array}{c}0.001 \\
(0.001)\end{array}$ & $\begin{array}{c}0.001 \\
(0.001)\end{array}$ & $\begin{array}{c}0.001 \\
(0.001)\end{array}$ \\
\hline Elevation & $\begin{array}{c}-0.0001^{* * *} \\
(0.00005)\end{array}$ & $\begin{array}{c}-0.0001^{* * *} \\
(0.00005)\end{array}$ & $\begin{array}{c}-0.0001^{* * *} \\
(0.00005)\end{array}$ & $\begin{array}{c}0.00004 \\
(0.0001)\end{array}$ & $\begin{array}{l}0.00004 \\
(0.0001)\end{array}$ & $\begin{array}{l}0.00004 \\
(0.0001)\end{array}$ & $\begin{array}{c}0.0005 \\
(0.0004)\end{array}$ & $\begin{array}{c}0.0005 \\
(0.0004)\end{array}$ & $\begin{array}{c}0.0005 \\
(0.0004)\end{array}$ \\
\hline Constant & $\begin{array}{c}0.826^{* * *} \\
(0.044) \\
\end{array}$ & $\begin{array}{c}0.826^{* * *} \\
(0.045) \\
\end{array}$ & $\begin{array}{c}0.827^{* * *} \\
(0.047) \\
\end{array}$ & $\begin{array}{l}0.160^{*} \\
(0.090) \\
\end{array}$ & $\begin{array}{l}0.159^{*} \\
(0.090) \\
\end{array}$ & $\begin{array}{l}0.173^{*} \\
(0.093) \\
\end{array}$ & $\begin{array}{c}0.384 \\
(0.316) \\
\end{array}$ & $\begin{array}{c}0.385 \\
(0.314) \\
\end{array}$ & $\begin{array}{c}0.379 \\
(0.332) \\
\end{array}$ \\
\hline Observations & 391 & 391 & 391 & 376 & 376 & 376 & 391 & 391 & 391 \\
\hline $\mathrm{R}^{2}$ & 0.650 & 0.648 & 0.640 & 0.390 & 0.389 & 0.385 & & & \\
\hline Adjusted $\mathrm{R}^{2}$ & 0.641 & 0.639 & 0.631 & 0.373 & 0.373 & 0.369 & & & \\
\hline
\end{tabular}




\section{A.5 Imperial Germany: Extension 3 - Using an Alternative Ver- sion of the BDEI Score}

The formula on which the BDEI score is based automatically and exponentially discounts the weight of observations that are farther away from a location under consideration. Therefore, the observations in the immediate vicinity of Germany have by far the largest impact on the score, while the weight of observations that are farther away approaches zero.

In spite of the score's technical features and despite the fact that sea travel was often much more efficient than land travel (which justifies the general inclusion of observations from the British Isles in our calculations) (cf. Benedictow, 2004, 185), we also present results based on an alternative BDEI score that systematically excludes all recorded outbreaks on the British Isles. ${ }^{43}$

The results can be found in Table A6 and are substantively almost identical to previously obtained results, even when including control variables. The fact that the results remain largely unchanged in substantive terms indicates that the formula that is the basis of the BDEI score already sufficiently discounts observations at a greater distance, rendering their substantive impact on our results marginal.

\footnotetext{
${ }^{43}$ In extension 13 (subsection A.15), we go one step further and manually exclude all but the neighboring regions (as well as Germany itself) from the calculation of the BDEI score.
} 
Table A6: Extension 3: Alternative Version of the BDEI Score

\begin{tabular}{|c|c|c|c|c|c|c|c|c|c|}
\hline & \multicolumn{9}{|c|}{ Dependent variable: } \\
\hline & \multirow{2}{*}{\multicolumn{3}{|c|}{$\begin{array}{l}\text { Land Inequality (Gini) } \\
\qquad O L S\end{array}$}} & \multirow{2}{*}{\multicolumn{3}{|c|}{$\begin{array}{c}\text { Conservative Party Vote Share } \\
\qquad O L S\end{array}$}} & \multirow{2}{*}{\multicolumn{3}{|c|}{$\begin{array}{c}\text { Net Electoral Disputes } \\
\text { glm: quasipoisson } \\
\text { link }=\text { log }\end{array}$}} \\
\hline & & & & & & & & & \\
\hline BDEI Score v1 (Alt.) & $\begin{array}{c}-0.058^{* * *} \\
(0.018)\end{array}$ & & & $\begin{array}{c}-0.149^{* * *} \\
(0.044)\end{array}$ & & & $\begin{array}{c}-0.381^{* *} \\
(0.152)\end{array}$ & & \\
\hline BDEI Score v3 (Alt.) & & $\begin{array}{c}-0.052^{* * *} \\
(0.017)\end{array}$ & & & $\begin{array}{c}-0.150^{* * *} \\
(0.046)\end{array}$ & & & $\begin{array}{c}-0.356^{* *} \\
(0.141)\end{array}$ & \\
\hline BDEI Score v5 (Alt.) & & & $\begin{array}{c}-0.037^{* * *} \\
(0.014)\end{array}$ & & & $\begin{array}{c}-0.139^{* * *} \\
(0.047)\end{array}$ & & & $\begin{array}{c}-0.289^{* *} \\
(0.134)\end{array}$ \\
\hline Urb. Dens. 1300 & $\begin{array}{l}-0.009 \\
(0.021)\end{array}$ & $\begin{array}{l}-0.007 \\
(0.022)\end{array}$ & $\begin{array}{l}-0.022 \\
(0.022)\end{array}$ & $\begin{array}{l}0.115^{*} \\
(0.064)\end{array}$ & $\begin{array}{l}0.138^{*} \\
(0.071)\end{array}$ & $\begin{array}{l}0.139^{*} \\
(0.074)\end{array}$ & $\begin{array}{c}0.241 \\
(0.164)\end{array}$ & $\begin{array}{c}0.275 \\
(0.173)\end{array}$ & $\begin{array}{c}0.237 \\
(0.178)\end{array}$ \\
\hline Dist. Maj. Port & $\begin{array}{c}-0.001^{* * *} \\
(0.0002)\end{array}$ & $\begin{array}{c}-0.001^{* * *} \\
(0.0002)\end{array}$ & $\begin{array}{c}-0.001^{* * *} \\
(0.0002)\end{array}$ & $\begin{array}{c}0.0002 \\
(0.001)\end{array}$ & $\begin{array}{c}0.0003 \\
(0.001)\end{array}$ & $\begin{array}{l}0.0003 \\
(0.001)\end{array}$ & $\begin{array}{c}-0.0003 \\
(0.002)\end{array}$ & $\begin{array}{c}-0.0001 \\
(0.002)\end{array}$ & $\begin{array}{c}-0.0004 \\
(0.002)\end{array}$ \\
\hline Dist. Trade City & $\begin{array}{l}-0.0001 \\
(0.0001)\end{array}$ & $\begin{array}{l}-0.0001 \\
(0.0001)\end{array}$ & $\begin{array}{l}-0.0001 \\
(0.0001)\end{array}$ & $\begin{array}{c}0.001^{* * *} \\
(0.0003)\end{array}$ & $\begin{array}{c}0.001^{* * *} \\
(0.0003)\end{array}$ & $\begin{array}{c}0.001^{* * *} \\
(0.0003)\end{array}$ & $\begin{array}{l}0.0005 \\
(0.001)\end{array}$ & $\begin{array}{c}0.001 \\
(0.001)\end{array}$ & $\begin{array}{c}0.001 \\
(0.001)\end{array}$ \\
\hline Dist. Ocean & $\begin{array}{c}0.0002 \\
(0.0002)\end{array}$ & $\begin{array}{c}0.0002 \\
(0.0002)\end{array}$ & $\begin{array}{c}0.0003 \\
(0.0002)\end{array}$ & $\begin{array}{c}-0.0003 \\
(0.001)\end{array}$ & $\begin{array}{l}-0.001 \\
(0.001)\end{array}$ & $\begin{array}{l}-0.001 \\
(0.001)\end{array}$ & $\begin{array}{l}-0.001 \\
(0.001)\end{array}$ & $\begin{array}{l}-0.002 \\
(0.001)\end{array}$ & $\begin{array}{l}-0.002 \\
(0.001)\end{array}$ \\
\hline Dist. River & $\begin{array}{c}-0.00002 \\
(0.0002)\end{array}$ & $\begin{array}{l}0.00000 \\
(0.0002)\end{array}$ & $\begin{array}{c}0.0001 \\
(0.0002)\end{array}$ & $\begin{array}{l}-0.001 \\
(0.001)\end{array}$ & $\begin{array}{l}-0.001 \\
(0.001)\end{array}$ & $\begin{array}{l}-0.001 \\
(0.001)\end{array}$ & $\begin{array}{l}0.0005 \\
(0.001)\end{array}$ & $\begin{array}{c}0.001 \\
(0.001)\end{array}$ & $\begin{array}{c}0.001 \\
(0.001)\end{array}$ \\
\hline Elevation & $\begin{array}{c}-0.0001^{* * *} \\
(0.0001)\end{array}$ & $\begin{array}{c}-0.0001^{* * *} \\
(0.0001)\end{array}$ & $\begin{array}{c}-0.0002^{* * *} \\
(0.0001)\end{array}$ & $\begin{array}{c}0.0001 \\
(0.0001)\end{array}$ & $\begin{array}{c}0.0001 \\
(0.0001)\end{array}$ & $\begin{array}{c}0.0001 \\
(0.0001)\end{array}$ & $\begin{array}{c}0.001 \\
(0.0004)\end{array}$ & $\begin{array}{c}0.001 \\
(0.0004)\end{array}$ & $\begin{array}{c}0.0004 \\
(0.0004)\end{array}$ \\
\hline Constant & $\begin{array}{c}0.811^{* * *} \\
(0.025)\end{array}$ & $\begin{array}{c}0.816^{* * *} \\
(0.024)\end{array}$ & $\begin{array}{c}0.824^{* * *} \\
(0.023)\end{array}$ & $\begin{array}{l}0.119^{* *} \\
(0.053)\end{array}$ & $\begin{array}{c}0.129^{* *} \\
(0.052)\end{array}$ & $\begin{array}{c}0.164^{* * *} \\
(0.052)\end{array}$ & $\begin{array}{c}0.927^{* * *} \\
(0.139) \\
\end{array}$ & $\begin{array}{c}0.965^{* * *} \\
(0.147)\end{array}$ & $\begin{array}{c}1.045^{* * *} \\
(0.168)\end{array}$ \\
\hline Observations & 397 & 397 & 397 & 382 & 382 & 382 & 397 & 397 & 397 \\
\hline $\mathrm{R}^{2}$ & 0.635 & 0.627 & 0.608 & 0.301 & 0.303 & 0.298 & & & \\
\hline Adjusted $\mathrm{R}^{2}$ & 0.629 & 0.620 & 0.601 & 0.288 & 0.290 & 0.285 & & & \\
\hline
\end{tabular}




\section{A.6 Imperial Germany: Extension 4 - Conditioning Land In- equality on the Size of the Agricultural Workforce}

In this extension, we respond to the argument that land inequality is of the greatest socioeconomic relevance when agriculture is a key sector of the economy. The homogeneity/heterogeneity of an economy may influence the extent to which elites can use their dominant position in influencing voting patterns (Mares, 2015, 23-24, Ch. 4). Thus, we limit our analysis of land inequality patterns to districts that have a share of at least one third of workers engaged in the agricultural sector (Ziblatt, 2009). In other districts, where

industry and services account for a greater share of labor force utilization, our measure of land inequality is less substantively meaningful.

We replicate all previous analyses with this new constraint and find that all our results still hold, with small changes to coefficient magnitudes. Table A7 shows these results for models without (1-5) and with (6-10) control variables. Moreover, when applying Tobit models, as shown in Table A8, we also find results similar to previous Tobit regressions. 
Table A7: Extension 4: Conditioning Land Inequality on the Size of the Agricultural Workforce

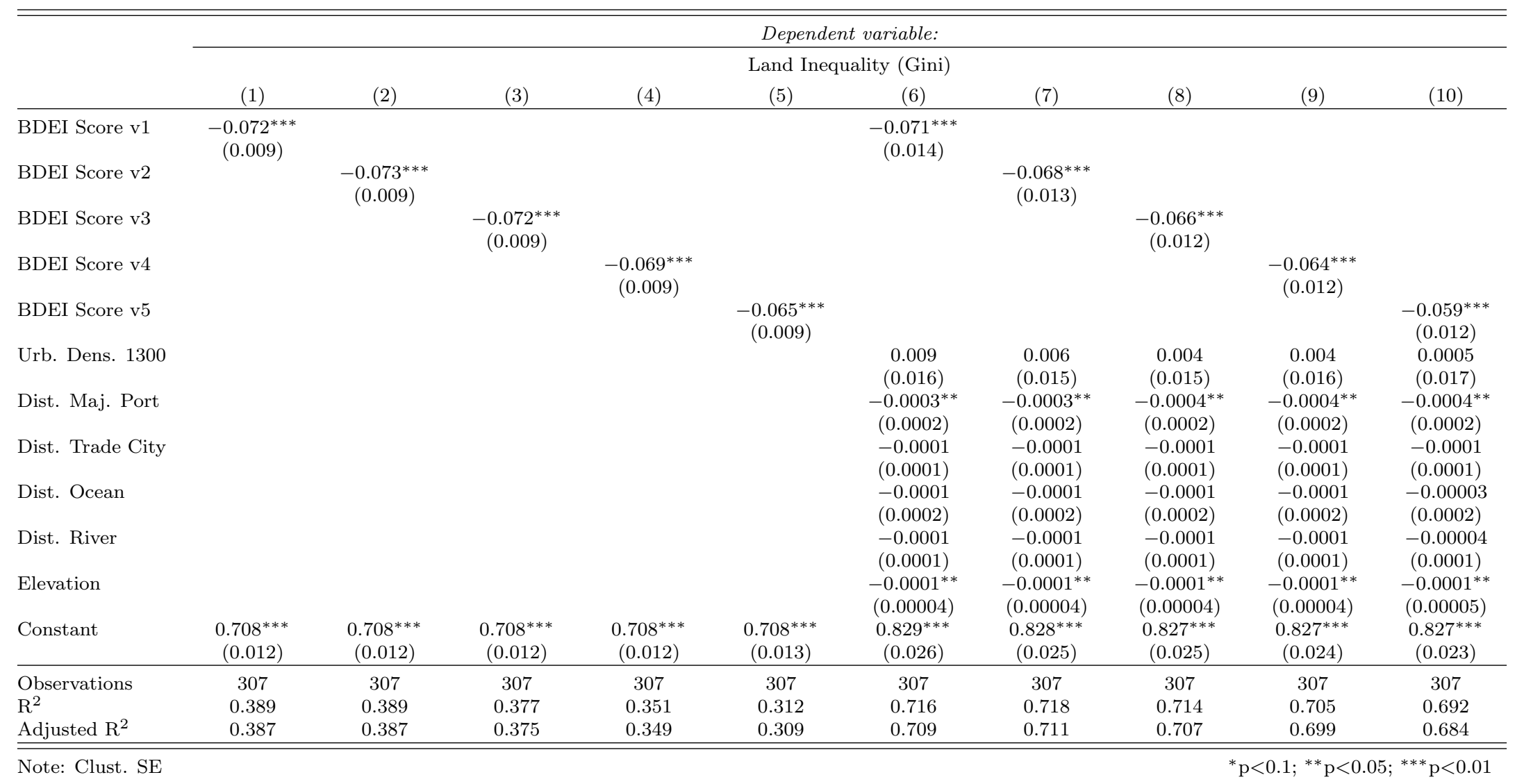


Table A8: Extension 4: Conditioning Land Inequality on the Size of the Agricultural Workforce (Tobit)

\begin{tabular}{|c|c|c|c|c|c|c|c|c|c|c|}
\hline & \multicolumn{10}{|c|}{ Dependent variable: } \\
\hline & & & & & Land I & uality (Gini) & & & & \\
\hline & $(1)$ & $(2)$ & $(3)$ & $(4)$ & $(5)$ & $(6)$ & $(7)$ & $(8)$ & $(9)$ & $(10)$ \\
\hline BDEI Score v1 & $\begin{array}{c}-0.072^{* * *} \\
(0.005)\end{array}$ & & & & & $\begin{array}{c}-0.071^{* * *} \\
(0.008)\end{array}$ & & & & \\
\hline BDEI Score v2 & & $\begin{array}{c}-0.073^{* * *} \\
(0.005)\end{array}$ & & & & & $\begin{array}{c}-0.068^{* * *} \\
(0.007)\end{array}$ & & & \\
\hline BDEI Score v3 & & & $\begin{array}{c}-0.072^{* * *} \\
(0.005)\end{array}$ & & & & & $\begin{array}{c}-0.066^{* * *} \\
(0.007)\end{array}$ & & \\
\hline BDEI Score v4 & & & & $\begin{array}{c}-0.069^{* * *} \\
(0.005)\end{array}$ & & & & & $\begin{array}{c}-0.064^{* * *} \\
(0.008)\end{array}$ & \\
\hline BDEI Score v5 & & & & & $\begin{array}{c}-0.065^{* * *} \\
(0.006)\end{array}$ & & & & & $\begin{array}{c}-0.059^{* * *} \\
(0.008)\end{array}$ \\
\hline Urb. Dens. 1300 & & & & & & $\begin{array}{c}0.009 \\
(0.011)\end{array}$ & $\begin{array}{c}0.006 \\
(0.011)\end{array}$ & $\begin{array}{c}0.004 \\
(0.011)\end{array}$ & $\begin{array}{c}0.004 \\
(0.012)\end{array}$ & $\begin{array}{l}0.0005 \\
(0.012)\end{array}$ \\
\hline Dist. Maj. Port & & & & & & $\begin{array}{c}-0.0003^{* * *} \\
(0.0001)\end{array}$ & $\begin{array}{c}-0.0003^{* * *} \\
(0.0001)\end{array}$ & $\begin{array}{c}-0.0004^{* * *} \\
(0.0001)\end{array}$ & $\begin{array}{c}-0.0004^{* * *} \\
(0.0001)\end{array}$ & $\begin{array}{c}-0.0004^{* * *} \\
(0.0001)\end{array}$ \\
\hline Dist. Trade City & & & & & & $\begin{array}{c}-0.0001^{* *} \\
(0.0001)\end{array}$ & $\begin{array}{c}-0.0001^{* *} \\
(0.0001)\end{array}$ & $\begin{array}{c}-0.0001^{*} \\
(0.0001)\end{array}$ & $\begin{array}{l}-0.0001 \\
(0.0001)\end{array}$ & $\begin{array}{l}-0.0001 \\
(0.0001)\end{array}$ \\
\hline Dist. Ocean & & & & & & $\begin{array}{l}-0.0001 \\
(0.0001)\end{array}$ & $\begin{array}{l}-0.0001 \\
(0.0001)\end{array}$ & $\begin{array}{l}-0.0001 \\
(0.0001)\end{array}$ & $\begin{array}{l}-0.0001 \\
(0.0001)\end{array}$ & $\begin{array}{c}-0.00003 \\
(0.0001)\end{array}$ \\
\hline Dist. River & & & & & & $\begin{array}{l}-0.0001 \\
(0.0001)\end{array}$ & $\begin{array}{l}-0.0001 \\
(0.0001)\end{array}$ & $\begin{array}{l}-0.0001 \\
(0.0001)\end{array}$ & $\begin{array}{l}-0.0001 \\
(0.0001)\end{array}$ & $\begin{array}{c}-0.00004 \\
(0.0001)\end{array}$ \\
\hline Elevation & & & & & & $\begin{array}{c}-0.0001^{* * *} \\
(0.00003)\end{array}$ & $\begin{array}{c}-0.0001^{* * *} \\
(0.00003)\end{array}$ & $\begin{array}{c}-0.0001^{* * *} \\
(0.00003)\end{array}$ & $\begin{array}{c}-0.0001^{* * *} \\
(0.00003)\end{array}$ & $\begin{array}{c}-0.0001^{* * * *} \\
(0.00003)\end{array}$ \\
\hline Constant & $\begin{array}{c}0.708^{* * *} \\
(0.005)\end{array}$ & $\begin{array}{c}0.708^{* * *} \\
(0.005) \\
\end{array}$ & $\begin{array}{c}0.708^{* * *} \\
(0.005)\end{array}$ & $\begin{array}{c}0.708^{* * *} \\
(0.006) \\
\end{array}$ & $\begin{array}{c}0.708^{* * *} \\
(0.006) \\
\end{array}$ & $\begin{array}{c}0.829^{* * *} \\
(0.012) \\
\end{array}$ & $\begin{array}{c}0.828^{* * *} \\
(0.012) \\
\end{array}$ & $\begin{array}{c}0.827^{* * *} \\
(0.012)\end{array}$ & $\begin{array}{c}0.827^{* * *} \\
(0.012) \\
\end{array}$ & $\begin{array}{c}0.827^{* * *} \\
(0.013)\end{array}$ \\
\hline Observations & 307 & 307 & 307 & 307 & 307 & 307 & 307 & 307 & 307 & 307 \\
\hline Log Likelihood & 289.820 & 289.667 & 286.787 & 280.515 & 271.454 & 407.344 & 408.308 & 406.289 & 401.734 & 394.650 \\
\hline
\end{tabular}




\section{A.7 Imperial Germany: Extension 5 - Two-Stage Least Squares Models}

In our main analysis, we include a large number of geographic variables and urban density in 1300 to account for factors that could influence both local Black Death intensities and long-term political-economic outcomes. Despite our comprehensive attempts to control for these geographic variables, it would be desirable to more rigorously isolate the exogenous component of Black Death intensities. In this respect, we follow a similar strategy as Jedwab, Johnson and Koyama (2019b), who use the timing of the onset of the Plague to predict mortality rates in an instrumental-variable framework.

Similarly, as shown in Table A9 we use a combination of quarterly and yearly dummy variables to predict local mortality rates (LMR). The first-stage regressions show two inter-

esting patterns. First, outbreaks that began in the second quarter (April, May, June) led to the highest mortality rates. Second, places that were hit in later years had significantly lower mortality rates. These findings are fully consistent with the observations of historians that (1) the Black Death was most severe when it was able to spread in the late spring and summer months and (2) the overall intensity of the plague decreased over time (Benedictow, 2004; Campbell, 2016; Gottfried, 1983).

In a second step, we compute a new BDEI score based on the predicted rather than the actual values of local mortality rates. The results of the analysis for this second-stage BDEI score are in Table A10. The estimated effects of Black Death intensity are statistically significant and similar in magnitude to those reported in the main text. To the degree there is any change, the estimated impacts of the Black Death based on the 2SLS procedure is slightly larger for Conservative Party vote shares and net electoral disputes than the original OLS estimates. 
Table A9: Predicting Outbreak Intensity Based on Timing

\begin{tabular}{lc}
\hline \hline & Dependent variable: \\
\cline { 2 - 2 } First Quarter & Local Mortality Rate \\
& 0.035 \\
Second Quarter & $0.038)$ \\
& $0.087^{* *}$ \\
Third Quarter & $(0.035)$ \\
& -0.024 \\
1348 & $(0.037)$ \\
& $-0.157^{* *}$ \\
1349 & $(0.061)$ \\
& $-0.215^{* * *}$ \\
1350 & $(0.063)$ \\
& $-0.301^{* * *}$ \\
Constant & $(0.069)$ \\
& $0.584^{* * *}$ \\
\hline Observations & $(0.053)$ \\
$\mathrm{R}^{2}$ & 178 \\
Adjusted $\mathrm{R}^{2}$ & 0.188 \\
\hline \hline Note: OLS & 0.160 \\
\hline
\end{tabular}


Table A10: Extension 5: Using a Two-Stage Regression Approach

\begin{tabular}{|c|c|c|c|c|c|c|c|c|c|}
\hline & \multicolumn{9}{|c|}{ Dependent variable: } \\
\hline & \multirow{2}{*}{\multicolumn{3}{|c|}{$\begin{array}{l}\text { Land Inequality (Gini) } \\
\qquad O L S\end{array}$}} & \multirow{2}{*}{\multicolumn{3}{|c|}{$\begin{array}{c}\text { Conservative Party Vote Share } \\
\qquad O L S\end{array}$}} & \multirow{2}{*}{\multicolumn{3}{|c|}{$\begin{array}{l}\text { Net Electoral Disputes } \\
\text { glm: quasipoisson } \\
\text { link }=\log \end{array}$}} \\
\hline & & & & & & & & & \\
\hline & $(1)$ & $(2)$ & $(3)$ & $(4)$ & $(5)$ & $(6)$ & $(7)$ & (8) & (9) \\
\hline BDEI Score v1 (2SLS) & $\begin{array}{c}-0.055^{* * *} \\
(0.016)\end{array}$ & & & $\begin{array}{c}-0.145^{* * *} \\
(0.036)\end{array}$ & & & $\begin{array}{c}-0.325^{* *} \\
(0.140)\end{array}$ & & \\
\hline BDEI Score v3 (2SLS) & & $\begin{array}{c}-0.052^{* * *} \\
(0.014)\end{array}$ & & & $\begin{array}{c}-0.136^{* * *} \\
(0.033)\end{array}$ & & & $\begin{array}{c}-0.288^{* *} \\
(0.127)\end{array}$ & \\
\hline BDEI Score v5 (2SLS) & & & $\begin{array}{c}-0.052^{* * *} \\
(0.014)\end{array}$ & & & $\begin{array}{c}-0.146^{* * *} \\
(0.036)\end{array}$ & & & $\begin{array}{c}-0.280^{* *} \\
(0.130)\end{array}$ \\
\hline Urb. Dens. 1300 & $\begin{array}{l}-0.012 \\
(0.020)\end{array}$ & $\begin{array}{l}-0.014 \\
(0.019)\end{array}$ & $\begin{array}{l}-0.011 \\
(0.019)\end{array}$ & $\begin{array}{l}0.111^{*} \\
(0.058)\end{array}$ & $\begin{array}{l}0.105^{*} \\
(0.054)\end{array}$ & $\begin{array}{c}0.124^{* *} \\
(0.057)\end{array}$ & $\begin{array}{c}0.194 \\
(0.158)\end{array}$ & $\begin{array}{c}0.167 \\
(0.154)\end{array}$ & $\begin{array}{c}0.180 \\
(0.161)\end{array}$ \\
\hline Dist. Maj. Port & $\begin{array}{c}-0.001^{* * *} \\
(0.0002)\end{array}$ & $\begin{array}{c}-0.001^{* * *} \\
(0.0002)\end{array}$ & $\begin{array}{c}-0.001^{* * *} \\
(0.0002)\end{array}$ & $\begin{array}{l}0.0002 \\
(0.001)\end{array}$ & $\begin{array}{l}0.0002 \\
(0.001)\end{array}$ & $\begin{array}{c}0.0002 \\
(0.001)\end{array}$ & $\begin{array}{c}-0.0005 \\
(0.002)\end{array}$ & $\begin{array}{l}-0.001 \\
(0.002)\end{array}$ & $\begin{array}{l}-0.001 \\
(0.002)\end{array}$ \\
\hline Dist. Trade City & -0.0002 & -0.0002 & -0.0001 & $0.001^{* *}$ & $0.001^{* * *}$ & $0.001^{* * *}$ & 0.0001 & 0.0003 & 0.0003 \\
\hline Dist Ocean & $(0.0001)$ & $(0.0001)$ & $(0.0001)$ & $(0.0003)$ & $(0.0002)$ & $(0.0002)$ & $(0.001)$ & $(0.001)$ & $(0.001)$ \\
\hline Dist. Ocean & $\begin{array}{c}0.0001 \\
(0.0002)\end{array}$ & $\begin{array}{c}0.0001 \\
(0.0002)\end{array}$ & $\begin{array}{c}0.0001 \\
(0.0002)\end{array}$ & $\begin{array}{l}-0.001 \\
(0.001)\end{array}$ & $\begin{array}{l}-0.001 \\
(0.001)\end{array}$ & $\begin{array}{l}-0.001 \\
(0.001)\end{array}$ & $\begin{array}{l}-0.002 \\
(0.001)\end{array}$ & $\begin{array}{l}-0.002 \\
(0.001)\end{array}$ & $\begin{array}{l}-0.002 \\
(0.001)\end{array}$ \\
\hline Dist. River & 0.00000 & 0.00002 & 0.0001 & -0.001 & -0.001 & -0.001 & 0.001 & 0.001 & 0.001 \\
\hline & $(0.0001)$ & $(0.0001)$ & $(0.0001)$ & $(0.0005)$ & $(0.0005)$ & $(0.0005)$ & $(0.001)$ & $(0.001)$ & $(0.001)$ \\
\hline Elevation & $-0.0001^{* * *}$ & $\begin{array}{c}-0.0001^{* * *} \\
(0.00005)\end{array}$ & $\begin{array}{c}-0.0001^{* * *} \\
(0.00005)\end{array}$ & 0.0001 & 0.0001 & 0.0001 & 0.0005 & 0.0005 & 0.0005 \\
\hline Constant & $\begin{array}{c}0.839^{* * *} \\
(0.025)\end{array}$ & $\begin{array}{c}0.841^{* * *} \\
(0.025)\end{array}$ & $\begin{array}{c}0.845^{* * *} \\
(0.025)\end{array}$ & $\begin{array}{c}0.193^{* * *} \\
(0.063)\end{array}$ & $\begin{array}{c}0.198^{* * *} \\
(0.063)\end{array}$ & $\begin{array}{c}0.215^{* * *} \\
(0.061)\end{array}$ & $\begin{array}{c}1.092^{* * *} \\
(0.149)\end{array}$ & $\begin{array}{c}1.090^{* * *} \\
(0.149)\end{array}$ & $\begin{array}{c}1.118^{* * *} \\
(0.161)\end{array}$ \\
\hline Observations & 397 & 397 & 397 & 382 & 382 & 382 & 397 & 397 & 397 \\
\hline & 0.641 & 0.643 & 0.636 & 0.316 & 0.319 & 0.323 & & & \\
\hline Adjusted $\mathrm{R}^{2}$ & 0.635 & 0.636 & 0.629 & 0.303 & 0.307 & 0.310 & & & \\
\hline
\end{tabular}

Note: Clust. SE

${ }^{*} \mathrm{p}<0.1 ;{ }^{* *} \mathrm{p}<0.05 ;{ }^{* * *} \mathrm{p}<0.01$ 


\section{A.8 Imperial Germany: Extension 6 - Using Dummy Variables Instead of Absolute Distances to Geographic Features}

In our main regression analysis, we use absolute distances to several geographic features (such as the ocean or large rivers) to account for variation in proximity to trade routes. An alternative approach is to use dummy variables that indicate if a feature is within a certain distance. This approach is motivated by the possibility that areas in close vicinity to the ocean or a large river could be disproportionately affected by trade levels. Accordingly, in this extension, we replace all absolute distance measures with dummy variables indicating if any of our original geographic features are located at a distance of $10 \mathrm{~km}$ or less from the

electoral district. The results can be found in Table A11 and are fully in line with previous findings (with small changes to the magnitude of coefficients). 
Table A11: Extension 6: Using Dummy Variables Instead of Absolute Distances

\begin{tabular}{|c|c|c|c|c|c|c|c|c|c|}
\hline & \multicolumn{9}{|c|}{ Dependent variable: } \\
\hline & \multirow{2}{*}{\multicolumn{3}{|c|}{$\begin{array}{l}\text { Land Inequality (Gini) } \\
\qquad O L S\end{array}$}} & \multirow{2}{*}{\multicolumn{3}{|c|}{$\begin{array}{c}\text { Conservative Party Vote Share } \\
\qquad O L S\end{array}$}} & \multirow{2}{*}{\multicolumn{3}{|c|}{$\begin{array}{l}\text { Net Electoral Disputes } \\
\text { glm: quasipoisson } \\
\text { link }=\log \end{array}$}} \\
\hline & & & & & & & & & \\
\hline & $(1)$ & $(2)$ & $(3)$ & $(4)$ & $(5)$ & $(6)$ & (7) & $(8)$ & $(9)$ \\
\hline BDEI Score v1 & $\begin{array}{c}-0.054^{* * *} \\
(0.012)\end{array}$ & & & $\begin{array}{c}-0.119^{* * *} \\
(0.031)\end{array}$ & & & $\begin{array}{c}-0.272^{* * *} \\
(0.095)\end{array}$ & & \\
\hline BDEI Score v3 & & $\begin{array}{c}-0.047^{* * *} \\
(0.012)\end{array}$ & & & $\begin{array}{c}-0.102^{* * *} \\
(0.028)\end{array}$ & & & $\begin{array}{c}-0.229^{* * *} \\
(0.088)\end{array}$ & \\
\hline BDEI Score v5 & & & $\begin{array}{c}-0.043^{* * *} \\
(0.011)\end{array}$ & & & $\begin{array}{c}-0.094^{* * *} \\
(0.032)\end{array}$ & & & $\begin{array}{c}-0.209^{* *} \\
(0.089)\end{array}$ \\
\hline Urb. Dens. 1300 & $\begin{array}{c}0.016 \\
(0.010)\end{array}$ & $\begin{array}{c}0.009 \\
(0.009)\end{array}$ & $\begin{array}{c}0.008 \\
(0.010)\end{array}$ & $\begin{array}{c}0.030 \\
(0.037)\end{array}$ & $\begin{array}{c}0.013 \\
(0.034)\end{array}$ & $\begin{array}{c}0.012 \\
(0.036)\end{array}$ & $\begin{array}{l}0.141^{*} \\
(0.078)\end{array}$ & $\begin{array}{c}0.098 \\
(0.071)\end{array}$ & $\begin{array}{c}0.096 \\
(0.076)\end{array}$ \\
\hline Dummy Maj. Port & $\begin{array}{c}0.079^{* * *} \\
(0.018)\end{array}$ & $\begin{array}{c}0.082^{* * *} \\
(0.018)\end{array}$ & $\begin{array}{c}0.089^{* * *} \\
(0.019)\end{array}$ & $\begin{array}{l}-0.058 \\
(0.042)\end{array}$ & $\begin{array}{l}-0.053 \\
(0.043)\end{array}$ & $\begin{array}{l}-0.039 \\
(0.042)\end{array}$ & $\begin{array}{c}0.103 \\
(0.107)\end{array}$ & $\begin{array}{c}0.113 \\
(0.104)\end{array}$ & $\begin{array}{c}0.144 \\
(0.103)\end{array}$ \\
\hline Dummy Trade City & $\begin{array}{l}-0.025 \\
(0.022)\end{array}$ & $\begin{array}{l}-0.025 \\
(0.022)\end{array}$ & $\begin{array}{l}-0.025 \\
(0.022)\end{array}$ & $\begin{array}{c}-0.100^{* * *} \\
(0.025)\end{array}$ & $\begin{array}{c}-0.100^{* * *} \\
(0.025)\end{array}$ & $\begin{array}{c}-0.102^{* * *} \\
(0.026)\end{array}$ & $\begin{array}{l}-0.039 \\
(0.137)\end{array}$ & $\begin{array}{l}-0.038 \\
(0.136)\end{array}$ & $\begin{array}{l}-0.043 \\
(0.135)\end{array}$ \\
\hline Dummy Ocean & $\begin{array}{c}-0.035^{* *} \\
(0.015)\end{array}$ & $\begin{array}{c}-0.035^{* *} \\
(0.015)\end{array}$ & $\begin{array}{c}-0.033^{* *} \\
(0.015)\end{array}$ & $\begin{array}{c}0.009 \\
(0.054)\end{array}$ & $\begin{array}{c}0.005 \\
(0.057)\end{array}$ & $\begin{array}{c}0.010 \\
(0.058)\end{array}$ & $\begin{array}{c}0.176 \\
(0.135)\end{array}$ & $\begin{array}{c}0.168 \\
(0.132)\end{array}$ & $\begin{array}{c}0.176 \\
(0.132)\end{array}$ \\
\hline Dummy River & $\begin{array}{l}-0.018 \\
(0.011)\end{array}$ & $\begin{array}{c}-0.020^{*} \\
(0.012)\end{array}$ & $\begin{array}{c}-0.022^{*} \\
(0.012)\end{array}$ & $\begin{array}{l}-0.027 \\
(0.023)\end{array}$ & $\begin{array}{l}-0.032 \\
(0.023)\end{array}$ & $\begin{array}{l}-0.036 \\
(0.023)\end{array}$ & $\begin{array}{l}-0.167 \\
(0.112)\end{array}$ & $\begin{array}{l}-0.178 \\
(0.111)\end{array}$ & $\begin{array}{c}-0.188^{*} \\
(0.111)\end{array}$ \\
\hline Elevation & $\begin{array}{c}-0.0003^{* * *} \\
(0.00004)\end{array}$ & $\begin{array}{c}-0.0003^{* * *} \\
(0.00003)\end{array}$ & $\begin{array}{c}-0.0003^{* * *} \\
(0.00003)\end{array}$ & $\begin{array}{c}-0.0003^{* * *} \\
(0.0001)\end{array}$ & $\begin{array}{c}-0.0003^{* * *} \\
(0.0001)\end{array}$ & $\begin{array}{c}-0.0003^{* * *} \\
(0.0001)\end{array}$ & $\begin{array}{c}-0.001 \\
(0.0004)\end{array}$ & $\begin{array}{l}-0.001^{*} \\
(0.0004)\end{array}$ & $\begin{array}{l}-0.001^{*} \\
(0.0004)\end{array}$ \\
\hline Constant & $\begin{array}{c}0.807^{* * *} \\
(0.014)\end{array}$ & $\begin{array}{c}0.808^{* * *} \\
(0.014) \\
\end{array}$ & $\begin{array}{c}0.811^{* * *} \\
(0.014)\end{array}$ & $\begin{array}{c}0.238^{* * *} \\
(0.042) \\
\end{array}$ & $\begin{array}{c}0.243^{* * *} \\
(0.042) \\
\end{array}$ & $\begin{array}{c}0.249^{* * *} \\
(0.045) \\
\end{array}$ & $\begin{array}{c}1.005^{* * *} \\
(0.129) \\
\end{array}$ & $\begin{array}{c}1.019^{* * *} \\
(0.128) \\
\end{array}$ & $\begin{array}{c}1.035^{* * *} \\
(0.126) \\
\end{array}$ \\
\hline Observations & 397 & 397 & 397 & 382 & 382 & 382 & 397 & 397 & 397 \\
\hline $\mathrm{R}^{2}$ & 0.565 & 0.557 & 0.538 & 0.263 & 0.254 & 0.239 & & & \\
\hline Adjusted $\mathrm{R}^{2}$ & 0.557 & 0.549 & 0.530 & 0.249 & 0.240 & 0.225 & & & \\
\hline
\end{tabular}




\section{A.9 Imperial Germany: Extension 7 - Accounting for Historical Information Asymmetries}

In their study on historical political development, Ahmed and Stasavage (2020) suggest that information asymmetries between rulers and the ruled contributed to the emergence of government by council. Councils, as an early form of political participation, helped mitigate information asymmetries that posed challenges to the setting of tax rates.

Considering their historical focus, Ahmed and Stasavage (2020) construct and rely on a measure of caloric variability in agricultural production potential to quantify the aforementioned information asymmetries. Their indicator is based on the extent of local variations in the maximum caloric potential of crops grown in a given area. Accordingly, the variable is related to the most fundamental economic activity in pre-modern societies, namely, agriculture. Given the arguments by Ahmed and Stasavage (2020), caloric variability may be an important (co-)determinant of early democratic institutions, and thus an important variable to control for when analyzing the long-term influences on democratic practices. Therefore, we present an extended analysis below.

Following Ahmed and Stasavage (2020), we use data by Galor and Özak (2016) on maximum caloric potential (pre-1500 CE) to calculate local variation based on the standard deviation of surrounding raster cells (caloric variability). We then include this measure as an additional control variable in our regression analyses. We find that adding caloric variability does not affect the results in a way that would compromise our earlier interpretation. All details can be found in Table A12. 
Table A12: Extension 7: Accounting for Historical Information Asymmetries

\begin{tabular}{|c|c|c|c|c|c|c|c|c|c|}
\hline & \multicolumn{9}{|c|}{ Dependent variable: } \\
\hline & \multirow{2}{*}{\multicolumn{3}{|c|}{$\begin{array}{l}\text { Land Inequality (Gini) } \\
\qquad O L S\end{array}$}} & \multirow{2}{*}{\multicolumn{3}{|c|}{$\begin{array}{c}\text { Conservative Party Vote Share } \\
\qquad L S\end{array}$}} & \multirow{2}{*}{\multicolumn{3}{|c|}{$\begin{array}{c}\text { Net Electoral Disputes } \\
\text { glm: quasipoisson } \\
\text { link }=\log \end{array}$}} \\
\hline & & & & & & & & & \\
\hline & $(1)$ & $(2)$ & $(3)$ & $(4)$ & $(5)$ & $(6)$ & $(7)$ & $(8)$ & $(9)$ \\
\hline BDEI Score v1 & $\begin{array}{c}-0.052^{* * *} \\
(0.015)\end{array}$ & & & $\begin{array}{c}-0.142^{* * *} \\
(0.035)\end{array}$ & & & $\begin{array}{c}-0.313^{* *} \\
(0.135)\end{array}$ & & \\
\hline BDEI Score v3 & & $\begin{array}{c}-0.047^{* * *} \\
(0.014)\end{array}$ & & & $\begin{array}{c}-0.130^{* * *} \\
(0.032)\end{array}$ & & & $\begin{array}{c}-0.283^{* *} \\
(0.123)\end{array}$ & \\
\hline BDEI Score v5 & & & $\begin{array}{c}-0.042^{* * *} \\
(0.013)\end{array}$ & & & $\begin{array}{c}-0.136^{* * *} \\
(0.035)\end{array}$ & & & $\begin{array}{c}-0.294^{* *} \\
(0.127)\end{array}$ \\
\hline Urb. Dens. 1300 & $\begin{array}{l}-0.014 \\
(0.019)\end{array}$ & $\begin{array}{l}-0.019 \\
(0.019)\end{array}$ & $\begin{array}{l}-0.021 \\
(0.019)\end{array}$ & $\begin{array}{l}0.107^{*} \\
(0.057)\end{array}$ & $\begin{array}{l}0.097^{*} \\
(0.053)\end{array}$ & $\begin{array}{c}0.114^{* *} \\
(0.057)\end{array}$ & $\begin{array}{c}0.183 \\
(0.156)\end{array}$ & $\begin{array}{c}0.160 \\
(0.151)\end{array}$ & $\begin{array}{c}0.198 \\
(0.161)\end{array}$ \\
\hline Dist. Maj. Port & $\begin{array}{c}-0.001^{* * *} \\
(0.0002)\end{array}$ & $\begin{array}{c}-0.001^{* * *} \\
(0.0002)\end{array}$ & $\begin{array}{c}-0.001^{* * *} \\
(0.0002)\end{array}$ & $\begin{array}{l}0.0002 \\
(0.001)\end{array}$ & $\begin{array}{c}0.0002 \\
(0.001)\end{array}$ & $\begin{array}{c}0.0002 \\
(0.001)\end{array}$ & $\begin{array}{c}-0.0005 \\
(0.002)\end{array}$ & $\begin{array}{c}-0.0005 \\
(0.002)\end{array}$ & $\begin{array}{c}-0.0004 \\
(0.002)\end{array}$ \\
\hline Dist. Trade City & $\begin{array}{l}-0.0002 \\
(0.0001)\end{array}$ & $\begin{array}{l}-0.0002 \\
(0.0001)\end{array}$ & $\begin{array}{l}-0.0001 \\
(0.0001)\end{array}$ & $\begin{array}{l}0.001^{* *} \\
(0.0003)\end{array}$ & $\begin{array}{c}0.001^{* * *} \\
(0.0002)\end{array}$ & $\begin{array}{l}0.001^{* * *} \\
(0.0002)\end{array}$ & $\begin{array}{l}0.0001 \\
(0.001)\end{array}$ & $\begin{array}{l}0.0002 \\
(0.001)\end{array}$ & $\begin{array}{c}0.0003 \\
(0.001)\end{array}$ \\
\hline Dist. Ocean & $\begin{array}{c}0.0001 \\
(0.0002)\end{array}$ & $\begin{array}{c}0.0001 \\
(0.0002)\end{array}$ & $\begin{array}{c}0.0002 \\
(0.0002)\end{array}$ & $\begin{array}{l}-0.001 \\
(0.001)\end{array}$ & $\begin{array}{l}-0.001 \\
(0.001)\end{array}$ & $\begin{array}{l}-0.001 \\
(0.001)\end{array}$ & $\begin{array}{l}-0.002 \\
(0.001)\end{array}$ & $\begin{array}{l}-0.002 \\
(0.001)\end{array}$ & $\begin{array}{l}-0.002 \\
(0.002)\end{array}$ \\
\hline Dist. River & $\begin{array}{l}0.00000 \\
(0.0001)\end{array}$ & $\begin{array}{l}0.00002 \\
(0.0001)\end{array}$ & $\begin{array}{c}0.0001 \\
(0.0002)\end{array}$ & $\begin{array}{c}-0.001 \\
(0.0005)\end{array}$ & $\begin{array}{c}-0.001 \\
(0.0005)\end{array}$ & $\begin{array}{c}-0.001 \\
(0.0005)\end{array}$ & $\begin{array}{c}0.001 \\
(0.001)\end{array}$ & $\begin{array}{c}0.001 \\
(0.001)\end{array}$ & $\begin{array}{c}0.001 \\
(0.001)\end{array}$ \\
\hline Elevation & $\begin{array}{c}-0.0001^{* * *} \\
(0.0001)\end{array}$ & $\begin{array}{c}-0.0001^{* * *} \\
(0.0001)\end{array}$ & $\begin{array}{c}-0.0001^{* * *} \\
(0.0001)\end{array}$ & $\begin{array}{c}0.0001 \\
(0.0001)\end{array}$ & $\begin{array}{c}0.0001 \\
(0.0001)\end{array}$ & $\begin{array}{c}0.0001 \\
(0.0001)\end{array}$ & $\begin{array}{c}0.001 \\
(0.0005)\end{array}$ & $\begin{array}{c}0.001 \\
(0.0005)\end{array}$ & $\begin{array}{c}0.001 \\
(0.0005)\end{array}$ \\
\hline Caloric Variability & $\begin{array}{l}-0.00002 \\
(0.00003)\end{array}$ & $\begin{array}{l}-0.00002 \\
(0.00003)\end{array}$ & $\begin{array}{l}-0.00002 \\
(0.00003)\end{array}$ & $\begin{array}{c}0.00002 \\
(0.0001)\end{array}$ & $\begin{array}{l}0.00002 \\
(0.0001)\end{array}$ & $\begin{array}{l}0.00001 \\
(0.0001)\end{array}$ & $\begin{array}{c}-0.00002 \\
(0.0003)\end{array}$ & $\begin{array}{c}-0.00003 \\
(0.0003)\end{array}$ & $\begin{array}{c}-0.00004 \\
(0.0003)\end{array}$ \\
\hline Constant & $\begin{array}{c}0.845^{* * *} \\
(0.026) \\
\end{array}$ & $\begin{array}{c}0.844^{* * *} \\
(0.026) \\
\end{array}$ & $\begin{array}{c}0.843^{* * *} \\
(0.025) \\
\end{array}$ & $\begin{array}{c}0.206^{* * *} \\
(0.065) \\
\end{array}$ & $\begin{array}{c}0.206^{* * *} \\
(0.063) \\
\end{array}$ & $\begin{array}{c}0.215^{* * *} \\
(0.060) \\
\end{array}$ & $\begin{array}{c}1.123^{* * *} \\
(0.153) \\
\end{array}$ & $\begin{array}{c}1.120^{* * *} \\
(0.152) \\
\end{array}$ & $\begin{array}{c}1.152^{* * *} \\
(0.167)\end{array}$ \\
\hline Observations & 397 & 397 & 397 & 382 & 382 & 382 & 397 & 397 & 397 \\
\hline & 0.641 & 0.639 & 0.623 & 0.318 & 0.318 & 0.315 & & & \\
\hline Adjusted $\mathrm{R}^{2}$ & 0.633 & 0.631 & 0.616 & 0.303 & 0.304 & 0.301 & & & \\
\hline
\end{tabular}

Note: Clust. SE

${ }^{*} \mathrm{p}<0.1 ;{ }^{* *} \mathrm{p}<0.05 ;{ }^{* * *} \mathrm{p}<0.01$ 


\section{A.10 Imperial Germany: Extension 8 - Introducing Quasi- Random Spatial Fixed Effects}

In a response to Homola, Pereira and Tavits (2020b), Pepinsky, Goodman and Ziller (2020) suggest that historical measures based on distance to locations can lead to incorrect inferences if researchers do not account for unobserved regional heterogeneity in their empirical specifications. Among other suggestions, they advocate for the use of spatial fixed effects to address this issue.

In our case, the introduction of spatial fixed effects may be merited as well. However, there are two crucial differences between our paper and Homola, Pereira and Tavits (2020b): First, while Homola, Pereira and Tavits (2020b) have precise data on all concentration camp locations (a central object of inquiry in their study) and distances to them, our BDEI score is an imperfect extrapolation based on the best available data. As such, it likely includes a random noise component. Due to the fact that our measure is an extrapolation that may include random noise (meaning that there likely is an unobserved component of Black Death intensities), it is possible that spatial fixed effects will absorb variation that may actually be due to differences in the historical intensity of plague outbreaks. Second, our approach does not rely on the distance to the nearest outbreak location only. Instead, we take into account the entire set of outbreak locations weighted by their distance to the location under consideration. Therefore, our measure includes a spatial dependence component to begin with. These two factors make our analysis quite different from Homola, Pereira and Tavits (2020b). Although we present results with spatial fixed effects below, models that are limited to the spatial clustering of errors (as we use throughout the paper) instead of spatial fixed effects are our preferred option.

To model unobserved spatial heterogeneity without introducing post-treatment bias 
(since the formal groupings of districts are non-random and instead constructed based on socioeconomic and political characteristics), we create a quasi-random ${ }^{44}$ global spatial grid consisting of $75 \times 75$ rectangular cells that — in the geographic area where Germany is located — are approximately $300 \times 300 \mathrm{~km}$ in size. ${ }^{45}$ We observe that, without further modifications, the centroids of Imperial Germany's electoral districts are distributed across 16 rectangular cells. Cells with five or fewer observations are merged with the adjacent cell, which results in a total of 11 spatial groupings (fixed effect categories), with an average of 36.1 units per group.

Subsequently, we rerun our analysis with these spatial fixed effects as shown in Table A13. We find that the majority of our results still hold: With respect to land inequality, all versions of the BDEI score except for $\mathrm{v} 5$ are significant at $p<0.05$ (v2 and $\mathrm{v} 4$ are omitted from the table for space reasons). Furthermore, with respect to Conservative Party vote share, we can also confirm all previously obtained results (although there are smaller differences in magnitude). At the same time, introducing spatial fixed effects appears to weaken the results with respect to net electoral disputes: We no longer find results that are significant at $p<0.05$. While there is a strong reduction in the significance of the BDEI score's effect on electoral disputes, we caution the reader again to consider the possibility that the spatial fixed effects absorb some of the unobserved (i.e., imperfectly extrapolated) impact of the Black Death.

\footnotetext{
${ }^{44}$ The grid is only quasi-random because it is constructed based on the global latitude/longitude system and the international prime meridian.

${ }^{45}$ Due to the curvature of the earth, this is only a rough approximation. Actual size may vary by up to 30-40 km in east-west/north-south length depending on exact location.
} 
Table A13: Extension 8: Introducing Quasi-Random Spatial Fixed Effects

\begin{tabular}{|c|c|c|c|c|c|c|c|c|c|}
\hline & \multicolumn{9}{|c|}{ Dependent variable: } \\
\hline & \multirow{2}{*}{\multicolumn{3}{|c|}{$\begin{array}{l}\text { Land Inequality (Gini) } \\
\qquad O L S\end{array}$}} & \multirow{2}{*}{\multicolumn{3}{|c|}{$\begin{array}{c}\text { Conservative Party Vote Share } \\
\text { OLS }\end{array}$}} & \multirow{2}{*}{\multicolumn{3}{|c|}{$\begin{array}{c}\text { Net Electoral Disputes } \\
\text { glm: quasipoisson } \\
\text { link }=\log \end{array}$}} \\
\hline & & & & & & & & & \\
\hline & $(1)$ & $(2)$ & $(3)$ & $(4)$ & $(5)$ & $(6)$ & $(7)$ & $(8)$ & $(9)$ \\
\hline BDEI Score v1 & $\begin{array}{c}-0.067^{* * *} \\
(0.021)\end{array}$ & & & $\begin{array}{c}-0.177^{* * *} \\
(0.048)\end{array}$ & & & $\begin{array}{l}-0.343 \\
(0.217)\end{array}$ & & \\
\hline BDEI Score v3 & & $\begin{array}{c}-0.057^{* * *} \\
(0.020)\end{array}$ & & & $\begin{array}{c}-0.163^{* * *} \\
(0.043)\end{array}$ & & & $\begin{array}{l}-0.298 \\
(0.210)\end{array}$ & \\
\hline BDEI Score v5 & & & $\begin{array}{l}-0.019 \\
(0.024)\end{array}$ & & & $\begin{array}{c}-0.155^{* * *} \\
(0.050)\end{array}$ & & & $\begin{array}{l}-0.246 \\
(0.237)\end{array}$ \\
\hline Urb. Dens. 1300 & $\begin{array}{l}-0.005 \\
(0.024)\end{array}$ & $\begin{array}{l}-0.011 \\
(0.024)\end{array}$ & $\begin{array}{l}-0.027 \\
(0.027)\end{array}$ & $\begin{array}{c}0.034 \\
(0.067)\end{array}$ & $\begin{array}{c}0.025 \\
(0.064)\end{array}$ & $\begin{array}{c}0.035 \\
(0.063)\end{array}$ & $\begin{array}{c}0.076 \\
(0.223)\end{array}$ & $\begin{array}{c}0.055 \\
(0.226)\end{array}$ & $\begin{array}{c}0.063 \\
(0.255)\end{array}$ \\
\hline Dist. Maj. Port & $\begin{array}{c}-0.001^{* * *} \\
(0.0002)\end{array}$ & $\begin{array}{c}-0.001^{* * *} \\
(0.0002)\end{array}$ & $\begin{array}{c}-0.001^{* * *} \\
(0.0002)\end{array}$ & $\begin{array}{c}0.0002 \\
(0.001)\end{array}$ & $\begin{array}{c}0.0001 \\
(0.001)\end{array}$ & $\begin{array}{c}-0.00001 \\
(0.001)\end{array}$ & $\begin{array}{l}-0.001 \\
(0.002)\end{array}$ & $\begin{array}{l}-0.001 \\
(0.002)\end{array}$ & $\begin{array}{l}-0.001 \\
(0.002)\end{array}$ \\
\hline Dist. Trade City & $\begin{array}{l}-0.0001 \\
(0.0001)\end{array}$ & $\begin{array}{l}-0.0001 \\
(0.0002)\end{array}$ & $\begin{array}{c}-0.00003 \\
(0.0002)\end{array}$ & $\begin{array}{l}-0.0002 \\
(0.0003)\end{array}$ & $\begin{array}{l}-0.0002 \\
(0.0003)\end{array}$ & $\begin{array}{l}-0.0001 \\
(0.0003)\end{array}$ & $\begin{array}{c}0.001 \\
(0.002)\end{array}$ & $\begin{array}{c}0.001 \\
(0.002)\end{array}$ & $\begin{array}{c}0.001 \\
(0.002)\end{array}$ \\
\hline Dist. Ocean & $\begin{array}{c}0.0001 \\
(0.0002)\end{array}$ & $\begin{array}{c}0.0001 \\
(0.0002)\end{array}$ & $\begin{array}{c}0.0003 \\
(0.0002)\end{array}$ & $\begin{array}{l}-0.001 \\
(0.001)\end{array}$ & $\begin{array}{c}-0.001 \\
(0.0005)\end{array}$ & $\begin{array}{l}-0.001 \\
(0.001)\end{array}$ & $\begin{array}{l}-0.002 \\
(0.002)\end{array}$ & $\begin{array}{l}-0.002 \\
(0.002)\end{array}$ & $\begin{array}{l}-0.002 \\
(0.002)\end{array}$ \\
\hline Dist. River & $\begin{array}{c}0.0001 \\
(0.0001)\end{array}$ & $\begin{array}{c}0.0002 \\
(0.0002)\end{array}$ & $\begin{array}{c}0.0002 \\
(0.0002)\end{array}$ & $\begin{array}{c}-0.0002 \\
(0.001)\end{array}$ & $\begin{array}{c}-0.0002 \\
(0.001)\end{array}$ & $\begin{array}{c}-0.0001 \\
(0.001)\end{array}$ & $\begin{array}{c}0.001 \\
(0.001)\end{array}$ & $\begin{array}{c}0.001 \\
(0.001)\end{array}$ & $\begin{array}{c}0.001 \\
(0.001)\end{array}$ \\
\hline Elevation & $\begin{array}{c}-0.0001^{* * *} \\
(0.00005) \\
\end{array}$ & $\begin{array}{c}-0.0001^{* * *} \\
(0.00005) \\
\end{array}$ & $\begin{array}{c}-0.0001^{* * *} \\
(0.00005) \\
\end{array}$ & $\begin{array}{c}0.0001 \\
(0.0001) \\
\end{array}$ & $\begin{array}{c}0.0001 \\
(0.0001) \\
\end{array}$ & $\begin{array}{c}0.0001 \\
(0.0001) \\
\end{array}$ & $\begin{array}{c}0.0004 \\
(0.0004) \\
\end{array}$ & $\begin{array}{c}0.0004 \\
(0.0004) \\
\end{array}$ & $\begin{array}{c}0.0004 \\
(0.0005) \\
\end{array}$ \\
\hline Quasi-Random Spatial FE & $\checkmark$ & $\checkmark$ & $\checkmark$ & $\checkmark$ & $\checkmark$ & $\checkmark$ & $\checkmark$ & $\checkmark$ & $\checkmark$ \\
\hline Observations & 397 & 397 & 397 & 382 & 382 & 382 & 397 & 397 & 397 \\
\hline & 0.991 & 0.991 & 0.991 & 0.569 & 0.567 & 0.562 & & & \\
\hline Adjusted $\mathrm{R}^{2}$ & 0.991 & 0.991 & 0.990 & 0.548 & 0.546 & 0.540 & & & \\
\hline
\end{tabular}

Note: Clust. SE

${ }^{*} \mathrm{p}<0.1 ;{ }^{* *} \mathrm{p}<0.05 ;{ }^{* * *} \mathrm{p}<0.01$ 


\section{A.11 Imperial Germany: Extension 9 - Using Alternative Datasets of Plague Outbreaks}

In the main empirical analysis, we use data by Jedwab, Johnson and Koyama (2019a) to construct different versions of the BDEI score. We use these data because, to the best of our knowledge, they are the only data on the Black Death that do not simply record the occurrence of an outbreak but also its intensity. Accounting for the intensity of outbreaks is of crucial importance to our study for two reasons.

First, our theory is centered on explaining how variation in intensity accounts for different legacies of the Black Death. Therefore, measuring levels of intensity is necessary to properly test the theory.

Second, there were vast differences in local mortality rates across space and time. As we have shown in subsection A.7, places where the plague started at a later time experienced much milder outbreaks. This could help explain why the eastern parts of German-speaking Central Europe historically were less affected than other areas: For the most part, the Black Death only arrived there in 1351, the last year of the plague's initial outbreak.

While the data by Jedwab, Johnson and Koyama (2019a) on plague outbreaks have the crucial advantage of also including local mortality rates, readers of our paper may be concerned about the lack of observations that are in the easternmost parts of Germanspeaking central Europe. Even though the lack of concrete data on mortality rates in these parts is likely directly related to the much lower severity of the outbreak there, it would be desirable to identify alternative datasets that contain outbreaks in this part of Europe (even if such datasets omit crucial information on outbreak intensity) and check if our results hold when using them.

In this respect, we have identified two alternative datasets by Büntgen et al. (2012) and 
Schmid et al. (2015). These two datasets are closely related to each other. Specifically, Schmid et al. (2015) merges the original Büntgen et al. (2012) data with another dataset to create a comprehensive record of plague outbreaks for the entire medieval period (this dataset also makes some corrections to previous data entries).

For reasons of transparency, we provide results using both of these alternative datasets as the underlying data to construct the BDEI score. Since both cover a longer time period of plague outbreaks, we restrict the analysis to outbreaks in 1347-1352. Furthermore, since these data do not include information on mortality rates, but on the number of years during which a location was affected by the Black Death, when constructing the BDEI score, we have to assign a mortality rate of "1" and subsequently account for every year in which there was an outbreak (so that observations that had outbreaks in two years are weighted twice as much as observations that only had an outbreak in one year). This means that these scores are based on recurrence of the plague rather than its severity, though the two concepts are likely correlated.

The results are in Table A14, which based on data by Büntgen et al. (2012), and Table A15, which is based on data by Schmid et al. (2015). While there are minor differences to the main results, they are broadly in line with what we have found previously. In some cases, the magnitude of the effect is slightly larger, in others, it is slightly smaller. Most importantly, the coefficients of the BDEI score are consistently at the highest level of statistical significance $(p<0.01)$. 
Table A14: Extension 9: Using an Alternative Dataset of Plague Outbreaks (Büntgen et al., 2012 Data)

\begin{tabular}{|c|c|c|c|c|c|c|c|c|c|}
\hline & \multicolumn{9}{|c|}{ Dependent variable: } \\
\hline & \multirow{2}{*}{\multicolumn{3}{|c|}{$\begin{array}{l}\text { Land Inequality (Gini) } \\
\qquad O L S\end{array}$}} & \multirow{2}{*}{\multicolumn{3}{|c|}{$\begin{array}{c}\text { Conservative Party Vote Share } \\
\qquad O L S\end{array}$}} & \multirow{2}{*}{\multicolumn{3}{|c|}{$\begin{array}{l}\text { Net Electoral Disputes } \\
\text { glm: quasipoisson } \\
\text { link }=\log \end{array}$}} \\
\hline & & & & & & & & & \\
\hline & $(1)$ & $(2)$ & $(3)$ & $(4)$ & $(5)$ & $(6)$ & $(7)$ & (8) & (9) \\
\hline BDEI Score v1 (Alt. Data 1) & $\begin{array}{c}-0.058^{* * *} \\
(0.018)\end{array}$ & & & $\begin{array}{c}-0.145^{* * *} \\
(0.041)\end{array}$ & & & $\begin{array}{c}-0.368^{* *} \\
(0.148)\end{array}$ & & \\
\hline BDEI Score v3 (Alt. Data 1) & & $\begin{array}{c}-0.049^{* * *} \\
(0.014)\end{array}$ & & & $\begin{array}{c}-0.121^{* * *} \\
(0.037)\end{array}$ & & & $\begin{array}{c}-0.304^{* *} \\
(0.118)\end{array}$ & \\
\hline BDEI Score v5 (Alt. Data 1) & & & $\begin{array}{c}-0.041^{* * *} \\
(0.012)\end{array}$ & & & $\begin{array}{c}-0.110^{* * *} \\
(0.036)\end{array}$ & & & $\begin{array}{c}-0.262^{* *} \\
(0.102)\end{array}$ \\
\hline Urb. Dens. 1300 & $\begin{array}{l}-0.011 \\
(0.020)\end{array}$ & $\begin{array}{l}-0.016 \\
(0.018)\end{array}$ & $\begin{array}{l}-0.022 \\
(0.017)\end{array}$ & $\begin{array}{l}0.105^{*} \\
(0.061)\end{array}$ & $\begin{array}{c}0.092 \\
(0.059)\end{array}$ & $\begin{array}{c}0.087 \\
(0.059)\end{array}$ & $\begin{array}{c}0.214 \\
(0.158)\end{array}$ & $\begin{array}{c}0.171 \\
(0.149)\end{array}$ & $\begin{array}{c}0.143 \\
(0.147)\end{array}$ \\
\hline Dist. Maj. Port & $\begin{array}{c}-0.001^{* * *} \\
(0.0002)\end{array}$ & $\begin{array}{c}-0.001^{* * *} \\
(0.0002)\end{array}$ & $\begin{array}{c}-0.001^{* * *} \\
(0.0002)\end{array}$ & $\begin{array}{l}0.0001 \\
(0.001)\end{array}$ & $\begin{array}{l}0.0001 \\
(0.001)\end{array}$ & $\begin{array}{l}0.0002 \\
(0.001)\end{array}$ & $\begin{array}{c}-0.0004 \\
(0.002)\end{array}$ & $\begin{array}{c}-0.0005 \\
(0.002)\end{array}$ & $\begin{array}{l}-0.001 \\
(0.002)\end{array}$ \\
\hline Dist. Trade City & $\begin{array}{l}-0.0001 \\
(0.0001)\end{array}$ & $\begin{array}{l}-0.0001 \\
(0.0001)\end{array}$ & $\begin{array}{c}-0.00004 \\
(0.0001)\end{array}$ & $\begin{array}{c}0.001^{* * *} \\
(0.0003)\end{array}$ & $\begin{array}{l}0.001^{* * *} \\
(0.0003)\end{array}$ & $\begin{array}{l}0.001^{* * *} \\
(0.0003)\end{array}$ & $\begin{array}{l}0.0003 \\
(0.001)\end{array}$ & $\begin{array}{c}0.001 \\
(0.001)\end{array}$ & $\begin{array}{c}0.001 \\
(0.001)\end{array}$ \\
\hline Dist. Ocean & 0.0002 & 0.0002 & 0.0002 & -0.0003 & -0.0003 & -0.0004 & -0.001 & -0.001 & -0.001 \\
\hline & $(0.0002)$ & $(0.0002)$ & $(0.0002)$ & $(0.001)$ & $(0.001)$ & $(0.001)$ & $(0.001)$ & $(0.001)$ & $(0.001)$ \\
\hline Dist. River & -0.00001 & -0.00001 & 0.00001 & -0.001 & -0.001 & -0.001 & 0.001 & 0.001 & 0.001 \\
\hline & $(0.0002)$ & $(0.0002)$ & $(0.0002)$ & $(0.001)$ & $(0.001)$ & $(0.001)$ & $(0.001)$ & $(0.001)$ & $(0.001)$ \\
\hline Elevation & $-0.0001^{* * *}$ & $-0.0001^{* * *}$ & $-0.0001^{* * *}$ & 0.0001 & 0.0001 & 0.0001 & 0.001 & 0.001 & 0.0005 \\
\hline Constant & $\begin{array}{l}(0.0001) \\
0.814^{* * *}\end{array}$ & $\begin{array}{l}(0.0001) \\
0.809^{* * *}\end{array}$ & $\begin{array}{l}(0.0001) \\
0.811 * * *\end{array}$ & $\begin{array}{l}(0.0001) \\
0.125^{* *}\end{array}$ & $\begin{array}{l}(0.0001) \\
0.112^{* *}\end{array}$ & $\begin{array}{l}(0.0001) \\
0.116^{* *}\end{array}$ & $\begin{array}{l}(0.0004) \\
0.940 * * *\end{array}$ & $\begin{array}{l}(0.0004) \\
0.909 * * *\end{array}$ & $\begin{array}{l}(0.0004) \\
0.926^{* * *}\end{array}$ \\
\hline & $(0.025)$ & $(0.025)$ & $(0.024)$ & $(0.055)$ & $(0.053)$ & $(0.053)$ & $(0.138)$ & $(0.141)$ & $(0.146)$ \\
\hline Observations & 397 & 397 & 397 & 382 & 382 & 382 & 397 & 397 & 397 \\
\hline & 0.638 & 0.637 & 0.629 & 0.302 & 0.300 & 0.298 & & & \\
\hline Adjusted $\mathrm{R}^{2}$ & 0.632 & 0.631 & 0.622 & 0.289 & 0.287 & 0.284 & & & \\
\hline
\end{tabular}

Note: Clust. SE

${ }^{*} \mathrm{p}<0.1 ;{ }^{* *} \mathrm{p}<0.05 ;{ }^{* * *} \mathrm{p}<0.01$ 
Table A15: Extension 9: Using an Alternative Dataset of Plague Outbreaks (Schmid et al., 2015 Data)

\begin{tabular}{|c|c|c|c|c|c|c|c|c|c|}
\hline & \multicolumn{9}{|c|}{ Dependent variable: } \\
\hline & \multirow{2}{*}{\multicolumn{3}{|c|}{$\begin{array}{l}\text { Land Inequality (Gini) } \\
\qquad O L S\end{array}$}} & \multirow{2}{*}{\multicolumn{3}{|c|}{$\begin{array}{l}\text { Conservative Party Vote Share } \\
\qquad O L S\end{array}$}} & \multirow{2}{*}{\multicolumn{3}{|c|}{$\begin{array}{c}\text { Net Electoral Disputes } \\
\text { glm: quasipoisson } \\
\text { link }=\log \end{array}$}} \\
\hline & & & & & & & & & \\
\hline & $(1)$ & $(2)$ & $(3)$ & $(4)$ & $(5)$ & (6) & $(7)$ & $(8)$ & $(9)$ \\
\hline BDEI Score v1 (Alt. Data 2) & $\begin{array}{c}-0.059^{* * *} \\
(0.018)\end{array}$ & & & $\begin{array}{c}-0.149^{* * *} \\
(0.042)\end{array}$ & & & $\begin{array}{c}-0.376^{* *} \\
(0.150)\end{array}$ & & \\
\hline BDEI Score v3 (Alt. Data 2) & & $\begin{array}{c}-0.048^{* * *} \\
(0.014)\end{array}$ & & & $\begin{array}{c}-0.120^{* * *} \\
(0.035)\end{array}$ & & & $\begin{array}{c}-0.294^{* *} \\
(0.115)\end{array}$ & \\
\hline BDEI Score v5 (Alt. Data 2) & & & $\begin{array}{c}-0.041^{* * *} \\
(0.011)\end{array}$ & & & $\begin{array}{l}-0.108^{* * *} \\
(0.032)\end{array}$ & & & $\begin{aligned}-0.252^{* * *} & (0.098)\end{aligned}$ \\
\hline Urb. Dens. 1300 & $\begin{array}{l}-0.008 \\
(0.020)\end{array}$ & $\begin{array}{l}-0.015 \\
(0.018)\end{array}$ & $\begin{array}{l}-0.022 \\
(0.016)\end{array}$ & $\begin{array}{l}0.114^{*} \\
(0.063)\end{array}$ & $\begin{array}{c}0.095 \\
(0.058)\end{array}$ & $\begin{array}{c}0.084 \\
(0.055)\end{array}$ & $\begin{array}{c}0.235 \\
(0.163)\end{array}$ & $\begin{array}{c}0.173 \\
(0.149)\end{array}$ & $\begin{array}{c}0.134 \\
(0.143)\end{array}$ \\
\hline Dist. Maj. Port & $\begin{array}{c}-0.001^{* * *} \\
(0.0002)\end{array}$ & $\begin{array}{c}-0.001^{* * *} \\
(0.0002)\end{array}$ & $\begin{array}{c}-0.001^{* * *} \\
(0.0002)\end{array}$ & $\begin{array}{l}0.0001 \\
(0.001)\end{array}$ & $\begin{array}{l}0.0001 \\
(0.001)\end{array}$ & $\begin{array}{l}0.0001 \\
(0.001)\end{array}$ & $\begin{array}{l}-0.0004 \\
(0.002)\end{array}$ & $\begin{array}{l}-0.001 \\
(0.002)\end{array}$ & $\begin{array}{l}-0.001 \\
(0.001)\end{array}$ \\
\hline Dist. Trade City & $\begin{array}{l}-0.0001 \\
(0.0001)\end{array}$ & $\begin{array}{l}-0.0001 \\
(0.0001)\end{array}$ & $\begin{array}{l}-0.0001 \\
(0.0001)\end{array}$ & $\begin{array}{l}0.001^{* * *} \\
(0.0003)\end{array}$ & $\begin{array}{l}0.001^{* * *} \\
(0.0003)\end{array}$ & $\begin{array}{l}0.001^{* * *} \\
(0.0003)\end{array}$ & $\begin{array}{l}0.0003 \\
(0.001)\end{array}$ & $\begin{array}{c}0.001 \\
(0.001)\end{array}$ & $\begin{array}{c}0.001 \\
(0.001)\end{array}$ \\
\hline Dist. Ocean & $\begin{array}{c}0.0002 \\
(0.0002)\end{array}$ & $\begin{array}{c}0.0002 \\
(0.0002)\end{array}$ & $\begin{array}{c}0.0002 \\
(0.0002)\end{array}$ & $\begin{array}{c}-0.0003 \\
(0.001)\end{array}$ & $\begin{array}{c}-0.0004 \\
(0.001)\end{array}$ & $\begin{array}{l}-0.0005 \\
(0.001)\end{array}$ & $\begin{array}{l}-0.001 \\
(0.001)\end{array}$ & $\begin{array}{l}-0.001 \\
(0.001)\end{array}$ & $\begin{array}{l}-0.001 \\
(0.001)\end{array}$ \\
\hline Dist. River & $\begin{array}{c}-0.00001 \\
(0.0002)\end{array}$ & $\begin{array}{c}-0.00001 \\
(0.0002)\end{array}$ & $\begin{array}{l}0.00000 \\
(0.0002)\end{array}$ & $\begin{array}{l}-0.001 \\
(0.001)\end{array}$ & $\begin{array}{l}-0.001 \\
(0.001)\end{array}$ & $\begin{array}{l}-0.001 \\
(0.001)\end{array}$ & $\begin{array}{c}0.001 \\
(0.001)\end{array}$ & $\begin{array}{c}0.001 \\
(0.001)\end{array}$ & $\begin{array}{c}0.001 \\
(0.001)\end{array}$ \\
\hline Elevation & $\begin{array}{c}-0.0001^{* * *} \\
(0.0001)\end{array}$ & $\begin{array}{c}-0.0001^{* * *} \\
(0.0001)\end{array}$ & $\begin{array}{c}-0.0001^{* * *} \\
(0.0001)\end{array}$ & $\begin{array}{c}0.0001 \\
(0.0001)\end{array}$ & $\begin{array}{c}0.0001 \\
(0.0001)\end{array}$ & $\begin{array}{c}0.0001 \\
(0.0001)\end{array}$ & $\begin{array}{c}0.001 \\
(0.0004)\end{array}$ & $\begin{array}{c}0.001 \\
(0.0004)\end{array}$ & $\begin{array}{c}0.001 \\
(0.0004)\end{array}$ \\
\hline Constant & $\begin{array}{c}0.821^{* * *} \\
(0.025) \\
\end{array}$ & $\begin{array}{c}0.819^{* * *} \\
(0.025) \\
\end{array}$ & $\begin{array}{c}0.821^{* * *} \\
(0.025)\end{array}$ & $\begin{array}{c}0.143^{* *} \\
(0.057)\end{array}$ & $\begin{array}{c}0.138^{* *} \\
(0.056)\end{array}$ & $\begin{array}{c}0.145^{* * *} \\
(0.056) \\
\end{array}$ & $\begin{array}{c}0.988^{* * *} \\
(0.138) \\
\end{array}$ & $\begin{array}{c}0.971^{* * *} \\
(0.139) \\
\end{array}$ & $\begin{array}{c}0.992^{* * * *} \\
(0.143) \\
\end{array}$ \\
\hline Observations & 397 & 397 & 397 & 382 & 382 & 382 & 397 & 397 & 397 \\
\hline $\mathrm{R}^{2}$ & 0.638 & 0.640 & 0.635 & 0.304 & 0.305 & 0.307 & & & \\
\hline Adjusted $\mathrm{R}^{2}$ & 0.631 & 0.633 & 0.629 & 0.291 & 0.292 & 0.294 & & & \\
\hline
\end{tabular}

Note: Clust. SE

${ }^{*} \mathrm{p}<0.1 ;{ }^{* *} \mathrm{p}<0.05 ;{ }^{* * *} \mathrm{p}<0.01$ 


\section{A.12 Imperial Germany: Extension 10 - Introducing Pre-Treatment Spatial Fixed Effects}

In subsection A.10, we introduce quasi-random spatial fixed effects to address the possibility of unobserved regional heterogeneity. Yet quasi-random fixed effects may not be the only approach to dealing with heterogeneity in original conditions. A viable alternative is to use the borders of regions that existed prior to the observed treatment. Other than including fixed effects with "contemporary borders," including pre-treatment spatial fixed effects is not associated with the risk of introducing post-treatment bias. This issue is also discussed in more detail by Homola, Pereira and Tavits (2020a) who respond to criticism by Pepinsky, Goodman and Ziller (2020). For this, reason we use data by Nüssli and Nüssli (2008a) on the geographic borders of second-level administrative units within the Holy Roman Empire to create pre-treatment fixed effects.

Based on these geographic data, we obtain 40 different spatial fixed effects categories. As shown in Table A16, we find partial confirmation of our results. Specifically, we still find significant effects of historical Black Death intensities on Conservative Party vote share. At the same time, we cannot confirm some other previous results.

While using these pre-treatment spatial fixed effects could be seen as preferable to quasirandom fixed effects from a substantive perspective, there are severe empirical problems with them. Specifically, with a total of 40 categories, the average is at merely 10 observations per category. Given such a small average number of observations per category, it is not only likely that spatial fixed effects will absorb at least part of the variation that can actually be attributed to other variables, but the within-unit comparisons made possible by fixed effects are unlikely to have sufficient statistical power to identify existing associations (Homola, Pereira and Tavits, 2020b). A circumstance that further aggravates this problem is that, 
because of the Holy Roman Empire's high level of political fragmentation, most states are assigned to the larger political category of "small states of the Holy Roman Empire." Considering that many units are assigned to this broad category, the number of observations in the other categories is significantly below the average of 10 , leading to a median number of a mere three units per category. Under such circumstances, it becomes increasingly unlikely to find any statistical association due to low levels of statistical power. This is visible in the fact that, when analyzing Conservative Party vote share and electoral disputes, all variables (other than the BDEI score in the case of Conservative Party vote share) lose their statistical significance. Thus, while we still find partial confirmation of previous results, we caution the reader to be very careful when interpreting the results in Table A16. 
Table A16: Extension 10: Introducing Pre-Treatment Spatial Fixed Effects

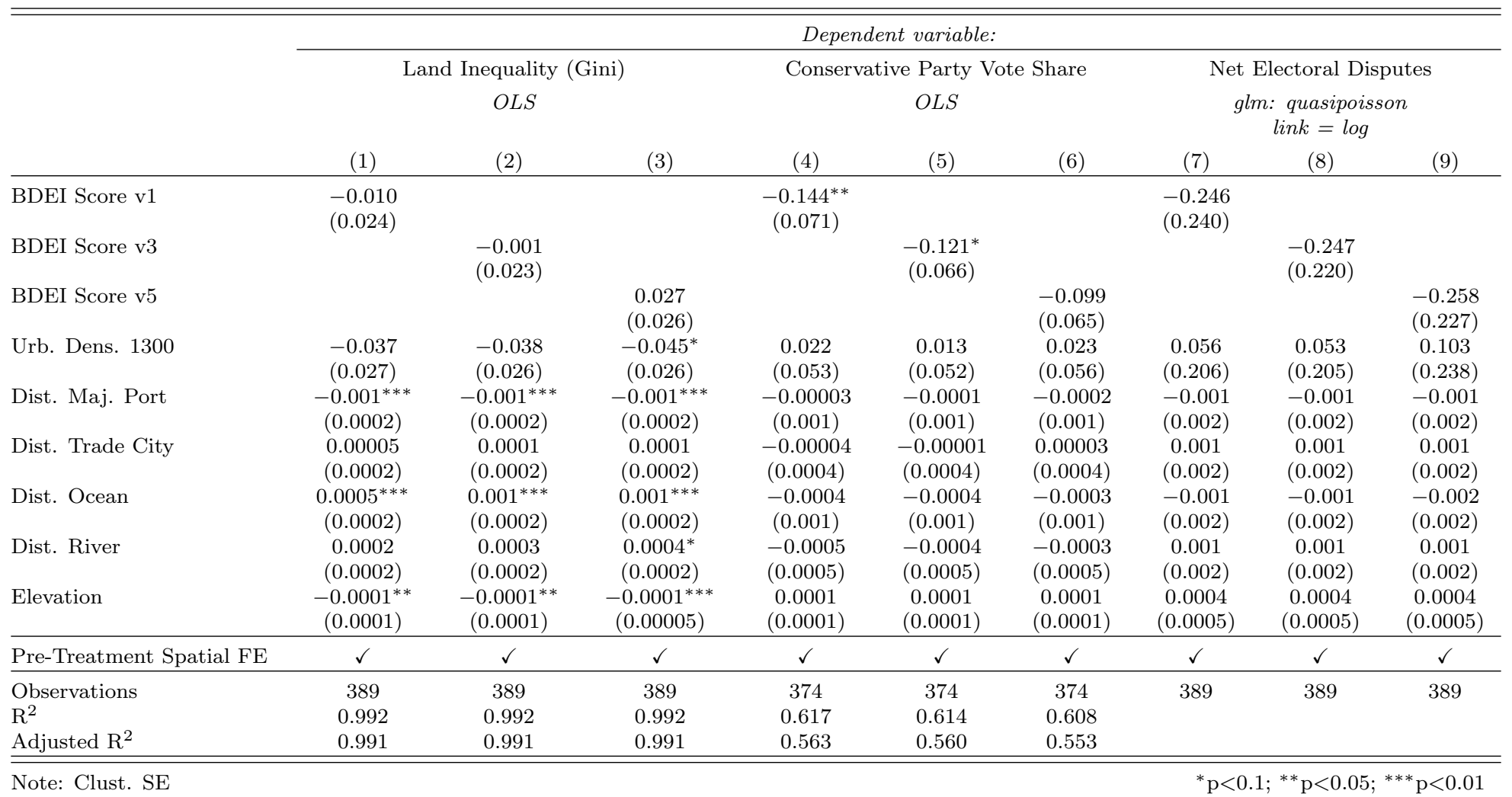




\section{A.13 Imperial Germany: Extension 11 - Extending the Analysis to Other Parties and Elections}

For a number of reasons, our main analysis of political outcomes in Imperial Germany focuses on the Conservative Party in the year 1871. The key substantive reason for this choice of the dependent variable is was the Conservative Party's political goals, socioeconomic basis, and electoral strategies, which made it a nearly perfect representation of the legacies we expect in areas that had low levels of Black Death exposure. Furthermore, our main analysis is limited to the year 1871 because, in subsequent decades, the confounding effect of nationallevel developments in terms of politics and socioeconomic transformations is likely to get larger.

Despite these substantive/theoretical reasons for limiting our main analysis to the Conservative Party in 1871, it would be desirable to verify if our results hold if we consider different dependent variables or election years. Therefore, as detailed below, we present three new analyses in this extension. The underlying data are by Sperber (1997).

Part I - Combined Vote Shares of All Conservative Parties (1871): Specifically, in part one of this extension we look at the combined vote share of both major Conservative Parties of early Imperial Germany: the Conservative Party and the Free Conservative Party (also known as German Empire Party). As we elaborate below (subsection A.24), while it was also a conservative party, the Free Conservative Party was significantly less radical in its goals and partly consisted of members of the industrial elite. Therefore, it is a less perfect representation of what we intend to measure, which is why we omit it from the main analysis.

Part II - Combined Vote Shares of All Major Liberal and Moderate Parties

(1871): Furthermore, in part two of this extension, we look at our theory's flip side: the 
electoral success of liberal and moderate parties. Our theory predicted that conservative parties that represent the traditional elites would do well in areas that historically had weak outbreaks of the Black Death. At the same time, we also predicted that more liberal parties would do well in areas that historically had extensive outbreaks of the Black Death. Thus, in this extension, we look at the combined vote share of the major liberal and moderate parties in the German Empire. Specifically, this includes (1) the National Liberal Party (Nationalliberale Partei, NLP), (2) the German Center Party (Deutsche Zentrumspartei or Zentrum $){ }^{46}$ (3) the Liberal Reich Party (Liberale Reichspartei, LRP), and (4) the German Progress Party (Deutsche Fortschrittspartei, DFP).

Part III - Conservative Party Vote Share in the the Election of 1874: Finally, a reasonable concern that reader's may have about limiting the analysis to the year 1871 is that there could be a strong effect of Germany's military victory in the same year on electoral outcomes. The military victory could have especially pronounced short-term effects on political behavior. Therefore, in part three of this extension, we extend our main analysis of Conservative Party vote shares to the year 1874.

As shown in Table A17, the results we obtain in each of these three extensions are in full accordance with our theoretical predictions. In the case of liberal and moderate parties this means an expected positive effect of historical Black Death intensities. The results broadly confirm previous findings and suggest that our theory's validity is not limited to a specific choice of political party/parties or election year(s).

\footnotetext{
${ }^{46}$ The German Center Party had the common denominator of catholicism, but it consisted of a wide variety of socioeconomic groups, sometimes with diverging political goals. While this meant that it also had a conservative wing, as a whole it is best categorized as a moderate party. This is particularly apparent when the Center Party is compared to the Conservative Party, with the latter embracing an extremely hierarchical and illiberal vision of society.
} 
Table A17: Extension 11: Extending the Analysis to Other Parties and Elections

\begin{tabular}{|c|c|c|c|c|c|c|c|c|c|}
\hline & \multicolumn{9}{|c|}{ Dependent variable: } \\
\hline & \multicolumn{3}{|c|}{ All Conservative Parties Vote Share (1871) } & \multicolumn{3}{|c|}{ All Liberal/Moderate Parties Vote Share (1871) } & \multicolumn{3}{|c|}{ Conservative Party Vote Share (1874) } \\
\hline & $(1)$ & $(2)$ & (3) & $(4)$ & $(5)$ & (6) & $(7)$ & $(8)$ & $(9)$ \\
\hline BDEI Score v1 & $\begin{array}{c}-0.161^{* * *} \\
(0.046)\end{array}$ & & & $\begin{array}{c}0.218^{* * *} \\
(0.038)\end{array}$ & & & $\begin{array}{c}-0.095^{* * *} \\
(0.020)\end{array}$ & & \\
\hline BDEI Score v3 & & $\begin{array}{c}-0.152^{* * *} \\
(0.041)\end{array}$ & & & $\begin{array}{c}0.210^{* * *} \\
(0.034)\end{array}$ & & & $\begin{array}{c}-0.089^{* * *} \\
(0.018)\end{array}$ & \\
\hline BDEI Score v5 & & & $\begin{array}{c}-0.169^{* * *} \\
(0.044)\end{array}$ & & & $\begin{array}{c}0.229^{* * *} \\
(0.037)\end{array}$ & & & $\begin{array}{c}-0.097^{* * *} \\
(0.019)\end{array}$ \\
\hline Urb. Dens. 1300 & $\begin{array}{c}0.074 \\
(0.068)\end{array}$ & $\begin{array}{c}0.067 \\
(0.064)\end{array}$ & $\begin{array}{c}0.097 \\
(0.068)\end{array}$ & $\begin{array}{l}-0.018 \\
(0.055)\end{array}$ & $\begin{array}{l}-0.012 \\
(0.052)\end{array}$ & $\begin{array}{l}-0.047 \\
(0.055)\end{array}$ & $\begin{array}{c}0.087^{* *} \\
(0.034)\end{array}$ & $\begin{array}{c}0.082^{* *} \\
(0.032)\end{array}$ & $\begin{array}{c}0.096^{* * *} \\
(0.033)\end{array}$ \\
\hline Dist. Maj. Port & $\begin{array}{c}0.001 \\
(0.001)\end{array}$ & $\begin{array}{c}0.001 \\
(0.001)\end{array}$ & $\begin{array}{c}0.001 \\
(0.001)\end{array}$ & $\begin{array}{c}-0.001 \\
(0.0005)\end{array}$ & $\begin{array}{c}-0.001 \\
(0.0004)\end{array}$ & $\begin{array}{c}-0.001 \\
(0.0005)\end{array}$ & $\begin{array}{c}0.0003 \\
(0.0004)\end{array}$ & $\begin{array}{c}0.0003 \\
(0.0003)\end{array}$ & $\begin{array}{c}0.0003 \\
(0.0003)\end{array}$ \\
\hline Dist. Trade City & $\begin{array}{c}-0.00001 \\
(0.0004)\end{array}$ & $\begin{array}{l}0.00004 \\
(0.0004)\end{array}$ & $\begin{array}{c}0.0001 \\
(0.0004)\end{array}$ & $\begin{array}{l}0.001^{* *} \\
(0.0004)\end{array}$ & $\begin{array}{l}0.001^{* *} \\
(0.0003)\end{array}$ & $\begin{array}{l}0.001^{* *} \\
(0.0003)\end{array}$ & $\begin{array}{l}0.001^{* * *} \\
(0.0002)\end{array}$ & $\begin{array}{l}0.001^{* * *} \\
(0.0002)\end{array}$ & $\begin{array}{l}0.001^{* * *} \\
(0.0002)\end{array}$ \\
\hline Dist. Ocean & $\begin{array}{l}-0.001 \\
(0.001)\end{array}$ & $\begin{array}{l}-0.001 \\
(0.001)\end{array}$ & $\begin{array}{c}-0.001^{*} \\
(0.001)\end{array}$ & $\begin{array}{l}0.001^{* *} \\
(0.0004)\end{array}$ & $0.001^{* * *}$ & $\begin{array}{l}0.001^{* * *} \\
(0.0004)\end{array}$ & $\begin{array}{l}-0.0005 \\
(0.0003)\end{array}$ & $\begin{array}{c}-0.001 \\
(0.0003)\end{array}$ & $\begin{array}{l}-0.001^{*} \\
(0.0003)\end{array}$ \\
\hline Dist. River & $\begin{array}{l}-0.001 \\
(0.001)\end{array}$ & $\begin{array}{l}-0.001 \\
(0.001)\end{array}$ & $\begin{array}{l}-0.001 \\
(0.001)\end{array}$ & $\begin{array}{l}0.0004 \\
(0.001)\end{array}$ & $\begin{array}{l}0.0004 \\
(0.001)\end{array}$ & $\begin{array}{l}0.0005 \\
(0.001)\end{array}$ & $\begin{array}{l}-0.0004 \\
(0.0003)\end{array}$ & $\begin{array}{l}-0.0004 \\
(0.0003)\end{array}$ & $\begin{array}{l}-0.0005 \\
(0.0003)\end{array}$ \\
\hline Elevation & $\begin{array}{l}-0.0001 \\
(0.0001)\end{array}$ & $\begin{array}{l}-0.0001 \\
(0.0001)\end{array}$ & $\begin{array}{c}-0.00003 \\
(0.0001)\end{array}$ & $\begin{array}{c}0.00002 \\
(0.0001)\end{array}$ & $\begin{array}{c}-0.00000 \\
(0.0001)\end{array}$ & $\begin{array}{c}-0.00002 \\
(0.0001)\end{array}$ & $\begin{array}{l}0.00003 \\
(0.0001)\end{array}$ & $\begin{array}{l}0.00003 \\
(0.0001)\end{array}$ & $\begin{array}{l}0.00004 \\
(0.0001)\end{array}$ \\
\hline Constant & $\begin{array}{c}0.339^{* * * *} \\
(0.079) \\
\end{array}$ & $\begin{array}{c}0.341^{* * *} \\
(0.077)\end{array}$ & $\begin{array}{c}0.359^{* * * *} \\
(0.072)\end{array}$ & $\begin{array}{c}0.431^{* * *} \\
(0.055)\end{array}$ & $\begin{array}{c}0.425^{* * *} \\
(0.054)\end{array}$ & $\begin{array}{c}0.405^{* * *} \\
(0.056)\end{array}$ & $\begin{array}{c}0.112^{* * *} \\
(0.041)\end{array}$ & $\begin{array}{c}0.113^{* * *} \\
(0.040)\end{array}$ & $\begin{array}{c}0.122^{* * *} \\
(0.038)\end{array}$ \\
\hline Observations & 382 & 382 & 382 & 380 & 380 & 380 & 397 & 397 & 397 \\
\hline & 0.233 & 0.238 & 0.244 & 0.392 & 0.405 & 0.409 & 0.289 & 0.292 & 0.291 \\
\hline Adjusted $\mathrm{R}^{2}$ & 0.219 & 0.224 & 0.230 & 0.381 & 0.394 & 0.398 & 0.276 & 0.279 & 0.279 \\
\hline
\end{tabular}




\section{A.14 Imperial Germany: Extension 12 - Weighting the BDEI Score by Population Sizes}

In our main analysis, we use the proportion of casualties from the Black Death weighted by its inverse distance to the location under consideration $(i)$ to calculate the BDEI score. When computing the original BDEI score, we do not take the population size of cities affected by the Black Death $(j)$ into account. However, arguably, any given outbreak may be more significant and more impactful, especially with respect to its surrounding areas, when an affected city is very large. Therefore, in this extension, we weight the influence of observations on the BDEI score by the respective city's population size.

Specifically, for this extension, the BDEI score is computed in the following way:

$$
\text { Raw BDEI Score } \text { }_{i}=\sum_{j=1}^{n} L M R_{j} * \pi_{j} *\left(1-D I S T_{j i}\right)^{k}
$$

where $\pi_{j} \in(0,1]$ is the weight that is given to observation $j$ in the calculation of the $B D E I$ score. $\pi_{j}$ is determined by the relative value of the natural logarithm of city $j$ 's population size. Furthermore, just as with the regular BDEI score, we standardize the values to achieve a mean of $\mu=0$ and a standard deviation of $\sigma=1$.

As shown in Table A18, even with the new weighted measure of historical Black Death intensities, our results hold. Specifically, the BDEI score shows a persistently significant negative effect on land inequality, Conservative Party vote share, and electoral disputes. 
Table A18: Extension 12: Weighting the BDEI Score by Population Size

\begin{tabular}{|c|c|c|c|c|c|c|c|c|c|}
\hline & \multicolumn{9}{|c|}{ Dependent variable: } \\
\hline & \multirow{2}{*}{\multicolumn{3}{|c|}{$\begin{array}{l}\text { Land Inequality (Gini) } \\
\text { OLS }\end{array}$}} & \multirow{2}{*}{\multicolumn{3}{|c|}{$\begin{array}{c}\text { Conservative Party Vote Share } \\
\text { OLS }\end{array}$}} & \multirow{2}{*}{\multicolumn{3}{|c|}{$\begin{array}{l}\text { Net Electoral Disputes } \\
\text { glm: quasipoisson } \\
\text { link }=\text { log }\end{array}$}} \\
\hline & & & & & & & & & \\
\hline & $(1)$ & $(2)$ & $(3)$ & $(4)$ & $(5)$ & $(6)$ & $(7)$ & $(8)$ & $(9)$ \\
\hline BDEI Score v1 (Weighted) & $\begin{array}{c}-0.053^{* * *} \\
(0.016)\end{array}$ & & & $\begin{array}{c}-0.140^{* * *} \\
(0.037)\end{array}$ & & & $\begin{array}{c}-0.336^{* *} \\
(0.138)\end{array}$ & & \\
\hline BDEI Score v3 (Weighted) & & $\begin{array}{c}-0.042^{* * *} \\
(0.013)\end{array}$ & & & $\begin{array}{c}-0.122^{* * *} \\
(0.032)\end{array}$ & & & $\begin{array}{c}-0.292^{* *} \\
(0.120)\end{array}$ & \\
\hline BDEI Score v5 (Weighted) & & & $\begin{array}{c}-0.023^{* *} \\
(0.011)\end{array}$ & & & $\begin{array}{c}-0.110^{* * *} \\
(0.034)\end{array}$ & & & $\begin{array}{c}-0.255^{* *} \\
(0.119)\end{array}$ \\
\hline Urb. Dens. 1300 & $\begin{array}{l}-0.014 \\
(0.019)\end{array}$ & $\begin{array}{l}-0.023 \\
(0.019)\end{array}$ & $\begin{array}{c}-0.042^{* *} \\
(0.019)\end{array}$ & $\begin{array}{c}0.103^{*} \\
(0.058)\end{array}$ & $\begin{array}{l}0.094^{*} \\
(0.055)\end{array}$ & $\begin{array}{c}0.088 \\
(0.055)\end{array}$ & $\begin{array}{c}0.195 \\
(0.155)\end{array}$ & $\begin{array}{c}0.175 \\
(0.150)\end{array}$ & $\begin{array}{c}0.165 \\
(0.158)\end{array}$ \\
\hline Dist. Maj. Port & $\begin{array}{c}-0.001^{* * *} \\
(0.0002)\end{array}$ & $\begin{array}{c}-0.001^{* * *} \\
(0.0002)\end{array}$ & $\begin{array}{c}-0.001^{* * *} \\
(0.0002)\end{array}$ & $\begin{array}{l}0.0002 \\
(0.001)\end{array}$ & $\begin{array}{l}0.0002 \\
(0.001)\end{array}$ & $\begin{array}{l}0.0001 \\
(0.001)\end{array}$ & $\begin{array}{c}-0.0004 \\
(0.002)\end{array}$ & $\begin{array}{c}-0.0003 \\
(0.002)\end{array}$ & $\begin{array}{c}-0.0005 \\
(0.002)\end{array}$ \\
\hline Dist. Trade City & $\begin{array}{l}-0.0001 \\
(0.0001)\end{array}$ & $\begin{array}{l}-0.0001 \\
(0.0001)\end{array}$ & $\begin{array}{l}-0.0001 \\
(0.0001)\end{array}$ & $\begin{array}{c}0.001^{* * * *} \\
(0.0003)\end{array}$ & $\begin{array}{c}0.001^{* * * *} \\
(0.0002)\end{array}$ & $\begin{array}{c}0.001^{* * * *} \\
(0.0002)\end{array}$ & $\begin{array}{c}0.0002 \\
(0.001)\end{array}$ & $\begin{array}{l}0.0004 \\
(0.001)\end{array}$ & $\begin{array}{l}0.0003 \\
(0.001)\end{array}$ \\
\hline Dist. Ocean & $\begin{array}{c}0.0002 \\
(0.0002)\end{array}$ & $\begin{array}{c}0.0002 \\
(0.0002)\end{array}$ & $\begin{array}{l}0.0003^{*} \\
(0.0002)\end{array}$ & $\begin{array}{c}-0.0004 \\
(0.001)\end{array}$ & $\begin{array}{l}-0.001 \\
(0.001)\end{array}$ & $\begin{array}{l}-0.001 \\
(0.001)\end{array}$ & $\begin{array}{l}-0.001 \\
(0.001)\end{array}$ & $\begin{array}{l}-0.002 \\
(0.001)\end{array}$ & $\begin{array}{l}-0.002 \\
(0.002)\end{array}$ \\
\hline Dist. River & $\begin{array}{c}-0.00001 \\
(0.0002)\end{array}$ & $\begin{array}{l}0.00000 \\
(0.0002)\end{array}$ & $\begin{array}{c}0.0001 \\
(0.0002)\end{array}$ & $\begin{array}{l}-0.001 \\
(0.001)\end{array}$ & $\begin{array}{l}-0.001 \\
(0.001)\end{array}$ & $\begin{array}{l}-0.001 \\
(0.001)\end{array}$ & $\begin{array}{c}0.001 \\
(0.001)\end{array}$ & $\begin{array}{l}0.0005 \\
(0.001)\end{array}$ & $\begin{array}{c}0.001 \\
(0.001)\end{array}$ \\
\hline Elevation & $\begin{array}{c}-0.0001^{* * *} \\
(0.0001)\end{array}$ & $\begin{array}{c}-0.0001^{* * *} \\
(0.0001)\end{array}$ & $\begin{array}{c}-0.0002^{* * *} \\
(0.0001)\end{array}$ & $\begin{array}{c}0.0001 \\
(0.0001)\end{array}$ & $\begin{array}{c}0.0001 \\
(0.0001)\end{array}$ & $\begin{array}{c}0.0001 \\
(0.0001)\end{array}$ & $\begin{array}{c}0.001 \\
(0.0004)\end{array}$ & $\begin{array}{c}0.001 \\
(0.0004)\end{array}$ & $\begin{array}{c}0.0004 \\
(0.0004)\end{array}$ \\
\hline Constant & $0.825^{* * *}$ & $0.832^{* * *}$ & $0.834^{* * *}$ & $0.155^{* * *}$ & $0.177^{* * *}$ & $0.225^{* * *}$ & $1.013^{* * *}$ & $1.072^{* * *}$ & $1.195^{* * *}$ \\
\hline Observations & 397 & 397 & 397 & 382 & 382 & 382 & 397 & 397 & 397 \\
\hline & 0.638 & 0.628 & 0.601 & 0.309 & 0.308 & 0.294 & & & \\
\hline Adjusted $\mathrm{R}^{2}$ & 0.632 & 0.621 & 0.594 & 0.296 & 0.295 & 0.281 & & & \\
\hline
\end{tabular}




\section{A.15 Imperial Germany: Extension 13 - Considering Only Neighboring Regions in Computing the BDEI Score}

In computing the main BDEI score, we do not make discretionary choices as to which European regions to include. Instead, we rely on the smooth discount function to greatly reduce the weight of distant observations in calculating the score's overall value. Because of possible concerns about the extent to which certain observations should influence the score's value, we already manually exclude observations from the British Isles in an earlier extension (subsection A.5).

While, in our main analysis, we refrain from making these kinds of discretionary choices, it would additionally be of interest to see what happens if we only consider the Germanspeaking lands of Central Europe and the European regions that immediately border them. ${ }^{47}$ Therefore, in this extension, we limit the universe of considered outbreaks accordingly.

Table A19 shows the results. They are substantively nearly identical to previously obtained results. While BDEI score $v 5$ does not show statistical significance in two cases, all other regressions remain highly significant. The results imply that the function employed in the computation of the BDEI score sufficiently discounts observations at a greater distance, meaning that the inclusion or exclusion of specific European regions does not dramatically alter the results, particularly our central result regarding Conservative Party vote share.

\footnotetext{
${ }^{47}$ Such a procedure would involve the regions (with recorded outbreaks) that we generally label Austria, Belgium, Czechia, France, Germany itself, and Switzerland.
} 
Table A19: Extension 13: Considering Only Neighboring Countries in Computing the BDEI Score

\begin{tabular}{|c|c|c|c|c|c|c|c|c|c|}
\hline & \multicolumn{9}{|c|}{ Dependent variable: } \\
\hline & \multirow{2}{*}{\multicolumn{3}{|c|}{$\begin{array}{l}\text { Land Inequality (Gini) } \\
\qquad O L S\end{array}$}} & \multirow{2}{*}{\multicolumn{3}{|c|}{$\begin{array}{c}\text { Conservative Party Vote Share } \\
\qquad L L S\end{array}$}} & \multirow{2}{*}{\multicolumn{3}{|c|}{$\begin{array}{c}\text { Net Electoral Disputes } \\
\text { glm: quasipoisson } \\
\text { link }=\log \end{array}$}} \\
\hline & & & & & & & & & \\
\hline & $(1)$ & $(2)$ & $(3)$ & $(4)$ & $(5)$ & $(6)$ & $(7)$ & $(8)$ & $(9)$ \\
\hline BDEI Score v1 (Alt. 2) & $\begin{array}{c}-0.058^{* * *} \\
(0.018)\end{array}$ & & & $\begin{array}{c}-0.157^{* * *} \\
(0.043)\end{array}$ & & & $\begin{array}{c}-0.362^{* *} \\
(0.153)\end{array}$ & & \\
\hline BDEI Score v3 (Alt. 2) & & $\begin{array}{c}-0.047^{* * *} \\
(0.017)\end{array}$ & & & $\begin{array}{c}-0.180^{* * *} \\
(0.051)\end{array}$ & & & $\begin{array}{c}-0.307^{* *} \\
(0.151)\end{array}$ & \\
\hline BDEI Score v5 (Alt. 2) & & & $\begin{array}{l}-0.015 \\
(0.014)\end{array}$ & & & $\begin{array}{c}-0.118^{* * *} \\
(0.044)\end{array}$ & & & $\begin{array}{l}-0.147 \\
(0.116)\end{array}$ \\
\hline Urb. Dens. 1300 & $\begin{array}{l}-0.004 \\
(0.022)\end{array}$ & $\begin{array}{l}-0.010 \\
(0.024)\end{array}$ & $\begin{array}{c}-0.049^{* *} \\
(0.021)\end{array}$ & $\begin{array}{c}0.134^{* *} \\
(0.066)\end{array}$ & $\begin{array}{c}0.182^{* *} \\
(0.076)\end{array}$ & $\begin{array}{l}0.111^{*} \\
(0.066)\end{array}$ & $\begin{array}{c}0.254 \\
(0.172)\end{array}$ & $\begin{array}{c}0.253 \\
(0.189)\end{array}$ & $\begin{array}{c}0.078 \\
(0.164)\end{array}$ \\
\hline Dist. Maj. Port & $\begin{array}{c}-0.001^{* * *} \\
(0.0002)\end{array}$ & $\begin{array}{c}-0.001^{* * *} \\
(0.0002)\end{array}$ & $\begin{array}{c}-0.001^{* * *} \\
(0.0002)\end{array}$ & $\begin{array}{c}0.0002 \\
(0.001)\end{array}$ & $\begin{array}{c}0.0004 \\
(0.001)\end{array}$ & $\begin{array}{c}0.0001 \\
(0.001)\end{array}$ & $\begin{array}{c}-0.0004 \\
(0.002)\end{array}$ & $\begin{array}{c}-0.0005 \\
(0.002)\end{array}$ & $\begin{array}{l}-0.001 \\
(0.001)\end{array}$ \\
\hline Dist. Trade City & $\begin{array}{l}-0.0001 \\
(0.0001)\end{array}$ & $\begin{array}{l}-0.0001 \\
(0.0001)\end{array}$ & $\begin{array}{l}-0.0001 \\
(0.0001)\end{array}$ & $\begin{array}{c}0.001^{* * *} \\
(0.0003)\end{array}$ & $\begin{array}{c}0.001^{* * *} \\
(0.0002)\end{array}$ & $\begin{array}{c}0.001^{* * *} \\
(0.0003)\end{array}$ & $\begin{array}{l}0.0004 \\
(0.001)\end{array}$ & $\begin{array}{c}0.001 \\
(0.001)\end{array}$ & $\begin{array}{c}0.001 \\
(0.001)\end{array}$ \\
\hline Dist. Ocean & $\begin{array}{c}0.0002 \\
(0.0002)\end{array}$ & $\begin{array}{c}0.0002 \\
(0.0002)\end{array}$ & $\begin{array}{c}0.0004^{* *} \\
(0.0002)\end{array}$ & $\begin{array}{c}-0.0005 \\
(0.001)\end{array}$ & $\begin{array}{c}-0.001^{*} \\
(0.001)\end{array}$ & $\begin{array}{l}-0.001 \\
(0.001)\end{array}$ & $\begin{array}{l}-0.001 \\
(0.001)\end{array}$ & $\begin{array}{l}-0.002 \\
(0.002)\end{array}$ & $\begin{array}{l}-0.001 \\
(0.001)\end{array}$ \\
\hline Dist. River & $\begin{array}{c}-0.00001 \\
(0.0002)\end{array}$ & $\begin{array}{c}0.0001 \\
(0.0002)\end{array}$ & $\begin{array}{c}0.0002 \\
(0.0002)\end{array}$ & $\begin{array}{l}-0.001 \\
(0.001)\end{array}$ & $\begin{array}{c}-0.001 \\
(0.0005)\end{array}$ & $\begin{array}{l}-0.0004 \\
(0.0005)\end{array}$ & $\begin{array}{c}0.001 \\
(0.001)\end{array}$ & $\begin{array}{c}0.001 \\
(0.001)\end{array}$ & $\begin{array}{c}0.002 \\
(0.001)\end{array}$ \\
\hline Elevation & $\begin{array}{c}-0.0001^{* * *} \\
(0.0001)\end{array}$ & $\begin{array}{c}-0.0002^{* * *} \\
(0.0001)\end{array}$ & $\begin{array}{c}-0.0002^{* * *} \\
(0.0001)\end{array}$ & $\begin{array}{c}0.0001 \\
(0.0001)\end{array}$ & $\begin{array}{c}0.0001 \\
(0.0001)\end{array}$ & $\begin{array}{c}-0.00000 \\
(0.0001)\end{array}$ & $\begin{array}{c}0.0005 \\
(0.0004)\end{array}$ & $\begin{array}{c}0.0004 \\
(0.0004)\end{array}$ & $\begin{array}{c}0.0002 \\
(0.0004)\end{array}$ \\
\hline Constant & $\begin{array}{c}0.824^{* * *} \\
(0.025) \\
\end{array}$ & $\begin{array}{c}0.837^{* * *} \\
(0.024) \\
\end{array}$ & $\begin{array}{c}0.824^{* * *} \\
(0.026) \\
\end{array}$ & $\begin{array}{c}0.154^{* * *} \\
(0.058) \\
\end{array}$ & $\begin{array}{c}0.213^{* * *} \\
(0.057) \\
\end{array}$ & $\begin{array}{c}0.210^{* * *} \\
(0.058) \\
\end{array}$ & $\begin{array}{c}1.006^{* * *} \\
(0.141) \\
\end{array}$ & $\begin{array}{c}1.104^{* * *} \\
(0.173) \\
\end{array}$ & $\begin{array}{c}1.060^{* * *} \\
(0.195) \\
\end{array}$ \\
\hline Observations & 397 & 397 & 397 & 382 & 382 & 382 & 397 & 397 & 397 \\
\hline & 0.636 & 0.615 & 0.594 & 0.308 & 0.314 & 0.288 & & & \\
\hline Adjusted $\mathrm{R}^{2}$ & 0.629 & 0.608 & 0.586 & 0.295 & 0.301 & 0.275 & & & \\
\hline
\end{tabular}

Note: Clust. SE

${ }^{*} \mathrm{p}<0.1 ;{ }^{* *} \mathrm{p}<0.05 ;{ }^{* *} \mathrm{p}<0.01$ 


\section{A.16 Imperial Germany: Extension 14 - Accounting for Agri- cultural Potential}

In subsection A.9, we accounted for an important measure of agricultural production: caloric variability. The theoretical reasons behind the inclusion of this measure are introduced in this previous subsection and discussed in significant detail in Ahmed and Stasavage (2020).

In addition to this first analysis, it would be desirable to provide an extended analysis specifically accounting for the underlying measure of caloric potential (pre-1500) that was used to compute the variable caloric variability. The measure of caloric potential was introduced by Galor and Özak (2015) and refers to the local "maximum potential caloric yield attainable given the set of crops that are suitable for cultivation in the pre-1500 period" (Galor and Özak, 2015, 3). ${ }^{48}$ Importantly, this measure does not reflect the actual use of the land but merely its maximum potential, making it a plausibly exogenous measure (Galor and Özak, 2015, 2).

We rerun all our analyses using this additional measure of agricultural potential. The detailed results can be found in Table A20. They do not substantially differ from previous results, indicating that the BDEI score's explanatory power is not compromised by the introduction of agricultural potential as a further covariate.

\footnotetext{
${ }^{48}$ To account for the technology available at this time, (Galor and Özak, 2015, 4) assume "low level of inputs and rain-fed agriculture." For a study that uses these measures, see also Galor and Özak (2016).
} 
Table A20: Extension 14: Accounting for Agricultural Potential

\begin{tabular}{|c|c|c|c|c|c|c|c|c|c|}
\hline & \multicolumn{9}{|c|}{ Dependent variable: } \\
\hline & \multirow{2}{*}{\multicolumn{3}{|c|}{$\begin{array}{l}\text { Land Inequality (Gini) } \\
\qquad O L S\end{array}$}} & \multirow{2}{*}{\multicolumn{3}{|c|}{$\begin{array}{c}\text { Conservative Party Vote Share } \\
\text { OLS }\end{array}$}} & \multirow{2}{*}{\multicolumn{3}{|c|}{$\begin{array}{c}\text { Net Electoral Disputes } \\
\text { glm: quasipoisson } \\
\text { link }=\log \end{array}$}} \\
\hline & & & & & & & & & \\
\hline & $(1)$ & $(2)$ & $(3)$ & (4) & $(5)$ & $(6)$ & $(7)$ & $(8)$ & (9) \\
\hline BDEI Score v1 & $\begin{array}{c}-0.052^{* * *} \\
(0.016)\end{array}$ & & & $\begin{array}{c}-0.129^{* * *} \\
(0.035)\end{array}$ & & & $\begin{array}{c}-0.322^{* *} \\
(0.135)\end{array}$ & & \\
\hline BDEI Score v3 & & $\begin{array}{c}-0.047^{* * *} \\
(0.014)\end{array}$ & & & $\begin{array}{c}-0.118^{* * *} \\
(0.031)\end{array}$ & & & $\begin{array}{c}-0.291^{* *} \\
(0.123)\end{array}$ & \\
\hline BDEI Score v5 & & & $\begin{array}{c}-0.041^{* * *} \\
(0.014)\end{array}$ & & & $\begin{array}{c}-0.125^{* * *} \\
(0.033)\end{array}$ & & & $\begin{array}{c}-0.300^{* *} \\
(0.126)\end{array}$ \\
\hline Urb. Dens. 1300 & $\begin{array}{l}-0.015 \\
(0.020)\end{array}$ & $\begin{array}{l}-0.020 \\
(0.019)\end{array}$ & $\begin{array}{l}-0.023 \\
(0.020)\end{array}$ & $\begin{array}{c}0.085 \\
(0.057)\end{array}$ & $\begin{array}{c}0.076 \\
(0.053)\end{array}$ & $\begin{array}{l}0.092^{*} \\
(0.055)\end{array}$ & $\begin{array}{c}0.196 \\
(0.154)\end{array}$ & $\begin{array}{c}0.171 \\
(0.149)\end{array}$ & $\begin{array}{c}0.207 \\
(0.158)\end{array}$ \\
\hline Dist. Maj. Port & $\begin{array}{c}-0.001^{* * *} \\
(0.0002)\end{array}$ & $\begin{array}{c}-0.001^{* * *} \\
(0.0002)\end{array}$ & $\begin{array}{c}-0.001^{* * *} \\
(0.0002)\end{array}$ & $\begin{array}{l}0.0001 \\
(0.001)\end{array}$ & $\begin{array}{l}0.0001 \\
(0.001)\end{array}$ & $\begin{array}{c}0.0001 \\
(0.0005)\end{array}$ & $\begin{array}{c}-0.0004 \\
(0.002)\end{array}$ & $\begin{array}{c}-0.0004 \\
(0.002)\end{array}$ & $\begin{array}{c}-0.0003 \\
(0.002)\end{array}$ \\
\hline Dist. Trade City & $\begin{array}{c}-0.0002^{*} \\
(0.0001)\end{array}$ & $\begin{array}{l}-0.0002 \\
(0.0001)\end{array}$ & $\begin{array}{l}-0.0002 \\
(0.0001)\end{array}$ & $\begin{array}{c}0.0005^{* *} \\
(0.0002)\end{array}$ & $\begin{array}{l}0.001^{* *} \\
(0.0002)\end{array}$ & $\begin{array}{l}0.001^{* *} \\
(0.0002)\end{array}$ & $\begin{array}{l}0.0001 \\
(0.001)\end{array}$ & $\begin{array}{l}0.0003 \\
(0.001)\end{array}$ & $\begin{array}{l}0.0003 \\
(0.001)\end{array}$ \\
\hline Dist. Ocean & $\begin{array}{c}0.0001 \\
(0.0002)\end{array}$ & $\begin{array}{c}0.0001 \\
(0.0002)\end{array}$ & $\begin{array}{c}0.0002 \\
(0.0002)\end{array}$ & $\begin{array}{l}-0.001 \\
(0.001)\end{array}$ & $\begin{array}{l}-0.001 \\
(0.001)\end{array}$ & $\begin{array}{l}-0.001^{*} \\
(0.0005)\end{array}$ & $\begin{array}{l}-0.002 \\
(0.001)\end{array}$ & $\begin{array}{l}-0.002 \\
(0.001)\end{array}$ & $\begin{array}{l}-0.002 \\
(0.002)\end{array}$ \\
\hline Dist. River & $\begin{array}{c}0.00001 \\
(0.0002)\end{array}$ & $\begin{array}{c}0.00003 \\
(0.0002)\end{array}$ & $\begin{array}{c}0.0001 \\
(0.0002)\end{array}$ & $\begin{array}{l}-0.001 \\
(0.001)\end{array}$ & $\begin{array}{c}-0.001 \\
(0.0005)\end{array}$ & $\begin{array}{c}-0.001 \\
(0.0005)\end{array}$ & $\begin{array}{c}0.001 \\
(0.001)\end{array}$ & $\begin{array}{c}0.001 \\
(0.001)\end{array}$ & $\begin{array}{c}0.001 \\
(0.001)\end{array}$ \\
\hline Elevation & $\begin{array}{c}-0.0001^{* * *} \\
(0.00005)\end{array}$ & $\begin{array}{c}-0.0001^{* * *} \\
(0.0001)\end{array}$ & $\begin{array}{c}-0.0001^{* *} \\
(0.0001)\end{array}$ & $\begin{array}{c}0.0003^{* *} \\
(0.0001)\end{array}$ & $\begin{array}{c}0.0003^{* *} \\
(0.0001)\end{array}$ & $\begin{array}{c}0.0003^{* *} \\
(0.0001)\end{array}$ & $\begin{array}{l}0.0004 \\
(0.001)\end{array}$ & $\begin{array}{l}0.0004 \\
(0.001)\end{array}$ & $\begin{array}{l}0.0004 \\
(0.001)\end{array}$ \\
\hline Caloric Potential & $\begin{array}{c}0.00001 \\
(0.00001)\end{array}$ & $\begin{array}{c}0.00001 \\
(0.00001)\end{array}$ & $\begin{array}{c}0.00001 \\
(0.00001)\end{array}$ & $\begin{array}{c}0.0001^{*} \\
(0.00004)\end{array}$ & $\begin{array}{c}0.0001^{*} \\
(0.00004)\end{array}$ & $\begin{array}{l}0.0001^{* *} \\
(0.00004)\end{array}$ & $\begin{array}{l}-0.0001 \\
(0.0001)\end{array}$ & $\begin{array}{c}-0.00005 \\
(0.0001)\end{array}$ & $\begin{array}{c}-0.00004 \\
(0.0001)\end{array}$ \\
\hline Constant & $\begin{array}{c}0.796^{* * *} \\
(0.141) \\
\end{array}$ & $\begin{array}{c}0.790^{* * *} \\
(0.142) \\
\end{array}$ & $\begin{array}{c}0.752^{* * *} \\
(0.145) \\
\end{array}$ & $\begin{array}{l}-0.540 \\
(0.407) \\
\end{array}$ & $\begin{array}{l}-0.549 \\
(0.399) \\
\end{array}$ & $\begin{array}{l}-0.585 \\
(0.397) \\
\end{array}$ & $\begin{array}{l}1.594^{*} \\
(0.833) \\
\end{array}$ & $\begin{array}{l}1.559^{*} \\
(0.828) \\
\end{array}$ & $\begin{array}{l}1.480^{*} \\
(0.845) \\
\end{array}$ \\
\hline Observations & 397 & 397 & 397 & 382 & 382 & 382 & 397 & 397 & 397 \\
\hline $\mathrm{R}^{2}$ & 0.641 & 0.639 & 0.624 & 0.330 & 0.331 & 0.330 & & & \\
\hline Adjusted $\mathrm{R}^{2}$ & 0.633 & 0.631 & 0.616 & 0.316 & 0.317 & 0.315 & & & \\
\hline
\end{tabular}

Note: Clust. SE

${ }^{*} \mathrm{p}<0.1 ;{ }^{* *} \mathrm{p}<0.05 ;{ }^{* *} \mathrm{p}<0.01$ 


\section{A.17 Weimar Germany: Descriptive Summary Statistics}

Table A.1 shows descriptive summary statistics for towns, cities, and counties in Weimar

Germany's 1930 and July 1932 elections. ${ }^{49}$

Table A21: Descriptive Statistics: Weimar Germany

\begin{tabular}{|c|c|c|c|c|c|c|c|c|}
\hline Variable & $\mathbf{n}$ & Min & $\mathbf{q}_{1}$ & $\overline{\mathbf{x}}$ & $\widetilde{\mathbf{x}}$ & $\mathrm{q}_{3}$ & Max & IQR \\
\hline BDEI Score v1 & 6304 & -3.49 & -0.51 & 0.00 & 0.21 & 0.85 & 1.34 & 1.36 \\
\hline BDEI Score v2 & 6304 & -3.00 & -0.57 & 0.00 & 0.19 & 0.85 & 1.47 & 1.42 \\
\hline BDEI Score v3 & 6304 & -2.81 & -0.57 & 0.00 & 0.20 & 0.82 & 1.53 & 1.39 \\
\hline BDEI Score v4 & 6304 & -2.79 & -0.56 & 0.00 & 0.26 & 0.77 & 1.50 & 1.33 \\
\hline BDEI Score v5 & 6304 & -2.81 & -0.53 & 0.00 & 0.35 & 0.73 & 1.38 & 1.27 \\
\hline NSDAP Vote Share (1930) & 4849 & 0.00 & 0.10 & 0.18 & 0.17 & 0.25 & 0.78 & 0.14 \\
\hline NSDAP Vote Share (Jul. 1932) & 1037 & 0.06 & 0.29 & 0.39 & 0.40 & 0.50 & 0.83 & 0.21 \\
\hline Urban Density (Standardized) (1300) & 6304 & -4.29 & -0.37 & 0.00 & 0.19 & 0.70 & 1.20 & 1.08 \\
\hline Distance to the Nearest Major Port $(\mathrm{km})$ & 6304 & 0.00 & 65.01 & 168.35 & 133.89 & 247.00 & 521.10 & 181.99 \\
\hline Distance to the Nearest Medieval Trade City $(\mathrm{km})$ & 6304 & 0.27 & 51.49 & 96.22 & 75.51 & 112.70 & 507.58 & 61.21 \\
\hline Distance to the Ocean $(\mathrm{km})$ & 6304 & 0.16 & 115.11 & 239.26 & 230.84 & 351.89 & 667.46 & 236.78 \\
\hline Distance to the Nearest Large River (km) & 6304 & 0.01 & 19.31 & 56.91 & 48.67 & 84.96 & 177.74 & 65.65 \\
\hline Elevation & 6299 & -15.00 & 60.00 & 196.10 & 139.00 & 290.00 & 1178.00 & 230.00 \\
\hline
\end{tabular}

\footnotetext{
${ }^{49}$ For the analysis of 1930 election results, we use town- and city-level observations as they represent the most fine-grained data available to us. For the analysis of July 1932 election results, we are restricted to the county level as no official city/town-level election data was disseminated at the time (Selb and Munzert, 2018).
} 


\section{A.18 Weimar Germany: Tobit Models as an Alternative Specifi- cation}

In our main empirical analysis, we use OLS regression to estimate the BDEI score's impact on NSDAP Vote Share (1930) and NSDAP Vote Share (Jul. 1932). Because these two outcome variables are truncated, i.e. both have an upper and lower bound, we also use Tobit models as an alternative empirical specification.

Table A2 shows the results with respect to NSDAP Vote Share (1930) when using Tobit models. Furthermore, Table A3 shows the results with respect to NSDAP Vote Share (Jul. 1932) when using Tobit models. In both cases, the direction, magnitude, and significance of the coefficients do not change in a way that would alter our previous interpretation. 
Table A22: NSDAP Vote Share (1930) (Tobit)

\begin{tabular}{|c|c|c|c|c|c|c|c|c|c|c|}
\hline & \multicolumn{10}{|c|}{ Dependent variable: } \\
\hline & \multicolumn{10}{|c|}{ NSDAP Vote Share (1930) } \\
\hline & $(1)$ & $(2)$ & $(3)$ & $(4)$ & $(5)$ & $(6)$ & $(7)$ & $(8)$ & $(9)$ & $(10)$ \\
\hline BDEI Score v1 & $\begin{array}{c}-0.019^{* * *} \\
(0.002)\end{array}$ & & & & & $\begin{array}{c}-0.028^{* * *} \\
(0.003)\end{array}$ & & & & \\
\hline BDEI Score v2 & & $\begin{array}{c}-0.020^{* * *} \\
(0.002)\end{array}$ & & & & & $\begin{array}{c}-0.028^{* * *} \\
(0.003)\end{array}$ & & & \\
\hline BDEI Score v3 & & & $\begin{array}{c}-0.020^{* * *} \\
(0.002)\end{array}$ & & & & & $\begin{array}{c}-0.028^{* * *} \\
(0.003)\end{array}$ & & \\
\hline BDEI Score v4 & & & & $\begin{array}{c}-0.019^{* * *} \\
(0.002)\end{array}$ & & & & & $\begin{array}{c}-0.028^{* * *} \\
(0.003)\end{array}$ & \\
\hline BDEI Score v5 & & & & & $\begin{array}{c}-0.017^{* * *} \\
(0.002)\end{array}$ & & & & & $\begin{array}{c}-0.026^{* * *} \\
(0.003)\end{array}$ \\
\hline Urb. Dens. 1300 & & & & & & $\begin{array}{c}0.032^{* * *} \\
(0.004)\end{array}$ & $\begin{array}{c}0.031^{* * *} \\
(0.004)\end{array}$ & $\begin{array}{c}0.030^{* * *} \\
(0.004)\end{array}$ & $\begin{array}{c}0.031^{* * *} \\
(0.004)\end{array}$ & $\begin{array}{c}0.031^{* * *} \\
(0.004)\end{array}$ \\
\hline Dist. Maj. Port & & & & & & $\begin{array}{c}0.0003^{* * *} \\
(0.0001)\end{array}$ & $\begin{array}{c}0.0003^{* * *} \\
(0.0001)\end{array}$ & $\begin{array}{c}0.0002^{* * *} \\
(0.0001)\end{array}$ & $\begin{array}{c}0.0002^{* * *} \\
(0.0001)\end{array}$ & $\begin{array}{c}0.0002^{* * *} \\
(0.0001)\end{array}$ \\
\hline Dist. Trade City & & & & & & $\begin{array}{c}0.0001^{* * *} \\
(0.00004)\end{array}$ & $\begin{array}{c}0.0001^{* * *} \\
(0.00004)\end{array}$ & $\begin{array}{c}0.0001^{* * *} \\
(0.00004)\end{array}$ & $\begin{array}{c}0.0001^{* * *} \\
(0.00004)\end{array}$ & $\begin{array}{c}0.0002^{* * *} \\
(0.00004)\end{array}$ \\
\hline Dist. Ocean & & & & & & $\begin{array}{c}-0.0004^{* * *} \\
(0.0001)\end{array}$ & $\begin{array}{c}-0.0004^{* * *} \\
(0.0001)\end{array}$ & $\begin{array}{c}-0.0004^{* * *} \\
(0.0001)\end{array}$ & $\begin{array}{c}-0.0004^{* * *} \\
(0.0001)\end{array}$ & $\begin{array}{c}-0.0004^{* * *} \\
(0.0001)\end{array}$ \\
\hline Dist. River & & & & & & $\begin{array}{c}-0.00004 \\
(0.0001)\end{array}$ & $\begin{array}{c}-0.00004 \\
(0.0001)\end{array}$ & $\begin{array}{c}-0.00003 \\
(0.0001)\end{array}$ & $\begin{array}{c}-0.00003 \\
(0.0001)\end{array}$ & $\begin{array}{c}-0.00000 \\
(0.0001)\end{array}$ \\
\hline Elevation & & & & & & $\begin{array}{l}0.0001^{* * *} \\
(0.00002)\end{array}$ & $\begin{array}{l}0.0001^{* * *} \\
(0.00002)\end{array}$ & $\begin{array}{l}0.0001^{* * *} \\
(0.00002)\end{array}$ & $\begin{array}{l}0.0001^{* * *} \\
(0.00002)\end{array}$ & $\begin{array}{l}0.0001^{* * *} \\
(0.00002)\end{array}$ \\
\hline Constant & $\begin{array}{c}0.184^{* * *} \\
(0.002)\end{array}$ & $\begin{array}{c}0.184^{* * *} \\
(0.002) \\
\end{array}$ & $\begin{array}{c}0.184^{* * *} \\
(0.002) \\
\end{array}$ & $\begin{array}{c}0.184^{* * *} \\
(0.002) \\
\end{array}$ & $\begin{array}{c}0.184^{* * *} \\
(0.002) \\
\end{array}$ & $\begin{array}{c}0.205^{* * *} \\
(0.007) \\
\end{array}$ & $\begin{array}{c}0.206^{* * *} \\
(0.007) \\
\end{array}$ & $\begin{array}{c}0.206^{* * *} \\
(0.007) \\
\end{array}$ & $\begin{array}{c}0.206^{* * *} \\
(0.007) \\
\end{array}$ & $\begin{array}{c}0.204^{* * *} \\
(0.007) \\
\end{array}$ \\
\hline Observations & 3,347 & 3,347 & 3,347 & 3,347 & 3,347 & 3,346 & 3,346 & 3,346 & 3,346 & 3,346 \\
\hline Log Likelihood & $2,730.987$ & $2,733.324$ & $2,732.725$ & $2,727.438$ & $2,717.827$ & $2,809.582$ & $2,813.133$ & $2,814.595$ & $2,812.536$ & $2,805.780$ \\
\hline
\end{tabular}


Table A23: NSDAP Vote Share (Jul. 1932) (Tobit)

\begin{tabular}{|c|c|c|c|c|c|c|c|c|c|c|}
\hline & \multicolumn{10}{|c|}{ Dependent variable: } \\
\hline & \multicolumn{10}{|c|}{ NSDAP Vote Share (Jul. 1932) } \\
\hline & $(1)$ & $(2)$ & $(3)$ & $(4)$ & $(5)$ & $(6)$ & $(7)$ & $(8)$ & $(9)$ & $(10)$ \\
\hline BDEI Score v1 & $\begin{array}{c}-0.037^{* * *} \\
(0.004)\end{array}$ & & & & & $\begin{array}{c}-0.085^{* * *} \\
(0.007)\end{array}$ & & & & \\
\hline BDEI Score v2 & & $\begin{array}{c}-0.038^{* * *} \\
(0.004)\end{array}$ & & & & & $\begin{array}{c}-0.082^{* * *} \\
(0.007)\end{array}$ & & & \\
\hline BDEI Score v3 & & & $\begin{array}{c}-0.039^{* * *} \\
(0.004)\end{array}$ & & & & & $\begin{array}{c}-0.084^{* * *} \\
(0.007)\end{array}$ & & \\
\hline BDEI Score v4 & & & & $\begin{array}{c}-0.037^{* * *} \\
(0.004)\end{array}$ & & & & & $\begin{array}{c}-0.087^{* * *} \\
(0.007)\end{array}$ & \\
\hline BDEI Score v5 & & & & & $\begin{array}{c}-0.034^{* * *} \\
(0.004)\end{array}$ & & & & & $\begin{array}{c}-0.088^{* * *} \\
(0.007)\end{array}$ \\
\hline Urb. Dens. 1300 & & & & & & $\begin{array}{c}0.085^{* * *} \\
(0.009)\end{array}$ & $\begin{array}{c}0.080^{* * * *} \\
(0.009)\end{array}$ & $\begin{array}{c}0.081^{* * *} \\
(0.009)\end{array}$ & $\begin{array}{c}0.087^{* * *} \\
(0.009)\end{array}$ & $\begin{array}{c}0.092^{* * *} \\
(0.010)\end{array}$ \\
\hline Dist. Maj. Port & & & & & & $\begin{array}{c}0.001^{* * *} \\
(0.0001)\end{array}$ & $\begin{array}{c}0.001^{* * *} \\
(0.0001)\end{array}$ & $\begin{array}{c}0.001^{* * *} \\
(0.0001)\end{array}$ & $\begin{array}{c}0.001^{* * *} \\
(0.0001)\end{array}$ & $\begin{array}{c}0.001^{* * *} \\
(0.0001)\end{array}$ \\
\hline Dist. Trade City & & & & & & $\begin{array}{l}-0.0001 \\
(0.0001)\end{array}$ & $\begin{array}{c}-0.00005 \\
(0.0001)\end{array}$ & $\begin{array}{c}-0.00004 \\
(0.0001)\end{array}$ & $\begin{array}{c}-0.00004 \\
(0.0001)\end{array}$ & $\begin{array}{c}-0.00002 \\
(0.0001)\end{array}$ \\
\hline Dist. Ocean & & & & & & $\begin{array}{c}-0.001^{* * *} \\
(0.0001)\end{array}$ & $\begin{array}{c}-0.001^{* * *} \\
(0.0001)\end{array}$ & $\begin{array}{c}-0.001^{* * *} \\
(0.0001)\end{array}$ & $\begin{array}{c}-0.001^{* * *} \\
(0.0001)\end{array}$ & $\begin{array}{c}-0.001^{* * *} \\
(0.0001)\end{array}$ \\
\hline Dist. River & & & & & & $\begin{array}{l}-0.0001 \\
(0.0001)\end{array}$ & $\begin{array}{l}-0.0001 \\
(0.0001)\end{array}$ & $\begin{array}{l}-0.0001 \\
(0.0001)\end{array}$ & $\begin{array}{l}-0.0001 \\
(0.0001)\end{array}$ & $\begin{array}{l}-0.0001 \\
(0.0001)\end{array}$ \\
\hline Elevation & & & & & & $\begin{array}{c}0.0002^{* * *} \\
(0.00004)\end{array}$ & $\begin{array}{c}0.0002^{* * *} \\
(0.00004)\end{array}$ & $\begin{array}{c}0.0002^{* * *} \\
(0.00004)\end{array}$ & $\begin{array}{c}0.0002^{* * *} \\
(0.00004)\end{array}$ & $\begin{array}{c}0.0002^{* * *} \\
(0.00004)\end{array}$ \\
\hline Constant & $\begin{array}{c}0.387^{* * *} \\
(0.004) \\
\end{array}$ & $\begin{array}{c}0.387^{* * *} \\
(0.004) \\
\end{array}$ & $\begin{array}{c}0.387^{* * *} \\
(0.004) \\
\end{array}$ & $\begin{array}{c}0.387^{* * *} \\
(0.004) \\
\end{array}$ & $\begin{array}{c}0.388^{* * *} \\
(0.004) \\
\end{array}$ & $\begin{array}{c}0.488^{* * *} \\
(0.015) \\
\end{array}$ & $\begin{array}{c}0.487^{* * *} \\
(0.015) \\
\end{array}$ & $\begin{array}{c}0.489^{* * *} \\
(0.015) \\
\end{array}$ & $\begin{array}{c}0.494^{* * *} \\
(0.015) \\
\end{array}$ & $\begin{array}{c}0.498^{* * *} \\
(0.015) \\
\end{array}$ \\
\hline Observations & 1,037 & 1,037 & 1,037 & 1,037 & 1,037 & 1,036 & 1,036 & 1,036 & 1,036 & 1,036 \\
\hline Log Likelihood & 562.126 & 563.685 & 564.228 & 561.960 & 556.707 & 657.591 & 660.040 & 663.904 & 667.058 & 665.638 \\
\hline
\end{tabular}




\section{A.19 Weimar Germany: Using An Alternative Dataset of NSDAP Vote Shares}

In this section of the appendix, we present an extended analyses of the NSDAP's vote share in Weimar elections based on alternative data by John O'Loughlin and colleagues (O'Loughlin, 2000; O’Loughlin, 2002; O'Loughlin, Flint and Anselin, 1994). We use these alternative data for two reasons: First, to verify if our results hold. Second, these data have previously been used in a number of prominent studies on the geography of the Nazi vote. At the same time, they also contain a number of clear inaccuracies, including double entries and incorrectly assigned names as well as unit numbers. Although we correct these entries manually to the best of our knowledge, given the number of identified errors, caution with these data is in order. Therefore, we present the obtained results only in the appendix.

\section{A.19.1 Outcome Variables}

In this analysis, we consider the same two primary variables as in the main analysis. Our extended analysis is at another level, though: the level of the county (Kreis) as assigned by O'Loughlin and colleagues (O'Loughlin, 2000; O'Loughlin, 2002; O'Loughlin, Flint and Anselin, 1994): ${ }^{50}$

1. NSDAP vote share (1930): These data reflect the NSDAP's vote share in the 1930 parliamentary elections. They are originally from a series of papers by John O'Loughlin (and colleagues) on the political geography of the Nazi vote (O'Loughlin, 2000; O'Loughlin, 2002; O'Loughlin, Flint and Anselin, 1994) and were provided by Selb and Munzert (2018).

2. NSDAP vote share (Jul. 1932): These data reflect the NSDAP's vote share in the July 1932 parliamentary elections. The source of these data is the same as above.

\footnotetext{
${ }^{50}$ O'Loughlin $(2002,225)$ labels these units "Kreisunits." Standard errors are clustered at the regional level with regions assigned to Kreis units based on regions in MPIDR and CGG (2013).
} 


\section{A.19.2 Descriptive Summary Statistics}

Table A24 shows descriptive summary statistics for counties in Weimar Germany based on the data by O'Loughlin and colleagues.

Table A24: Descriptive Statistics: Weimar Germany (O’Loughlin et al., 1994-2002 Data)

\begin{tabular}{|c|c|c|c|c|c|c|c|c|}
\hline Variable & $\mathbf{n}$ & Min & $q_{1}$ & $\overline{\mathbf{x}}$ & $\widetilde{\mathbf{x}}$ & $\mathbf{q}_{3}$ & Max & IQR \\
\hline BDEI Score v1 & 705 & -3.01 & -0.54 & 0.00 & 0.22 & 0.74 & 1.41 & 1.28 \\
\hline BDEI Score v2 & 705 & -2.64 & -0.61 & 0.00 & 0.22 & 0.75 & 1.56 & 1.36 \\
\hline BDEI Score v3 & 705 & -2.50 & -0.60 & 0.00 & 0.24 & 0.77 & 1.61 & 1.37 \\
\hline BDEI Score v4 & 705 & -2.47 & -0.55 & 0.00 & 0.28 & 0.75 & 1.55 & 1.30 \\
\hline BDEI Score v5 & 705 & -2.47 & -0.51 & 0.00 & 0.33 & 0.76 & 1.41 & 1.27 \\
\hline NSDAP Vote Share (1930) & 705 & 0.01 & 0.13 & 0.19 & 0.18 & 0.24 & 0.50 & 0.11 \\
\hline NSDAP Vote Share (Jul. 1932) (July) & 705 & 0.08 & 0.28 & 0.39 & 0.40 & 0.49 & 0.81 & 0.21 \\
\hline Urban Density (Standardized) (1300) & 705 & -3.52 & -0.33 & 0.00 & 0.21 & 0.73 & 1.14 & 1.06 \\
\hline Distance to the Nearest Major Port $(\mathrm{km})$ & 705 & 0.00 & 71.47 & 181.69 & 153.21 & 289.93 & 495.86 & 218.47 \\
\hline Distance to the Nearest Medieval Trade City (km) & 705 & 0.00 & 37.27 & 92.74 & 65.64 & 112.18 & 504.76 & 74.90 \\
\hline Distance to the Ocean $(\mathrm{km})$ & 705 & 0.00 & 109.16 & 251.00 & 245.31 & 377.94 & 641.72 & 268.79 \\
\hline Distance to the Nearest Large River (km) & 705 & 0.00 & 8.19 & 46.18 & 38.66 & 74.86 & 159.11 & 66.67 \\
\hline Elevation & 702 & 1.00 & 75.00 & 249.32 & 196.00 & 388.00 & 1212.00 & 313.00 \\
\hline
\end{tabular}

\section{A.19.3 Results}

Figure A1 and Figure A2 visualize our findings. They are extremely similar to the results that we have obtained in the main analysis.

Table A25 and Table A26 provide further information on the precise results. In the 1930 elections, a one standard deviation increase in the BDEI score leads to a reduction in the expected vote share of the NSDAP ranging from $0.016(1.6 \%)$ to $0.034(3.4 \%)(0.190$ to 0.406 standard deviations). In the elections of July 1932, a one standard deviation increase in the BDEI score leads to a reduction in the expected vote share of the NSDAP ranging from $0.043(4.3 \%)$ to $0.106(10.6 \%)$ (0.298 to 0.732 standard deviations).

Overall, the results obtained here provide another confirmation that the politicaleconomic equilibria created by the Black Death extended into the Weimar Republic, even if they were less coherent and more fragmented than in Imperial Germany (as is indicated by a generally weaker relationship). 
Figure A1: Predicted Values Plot: BDEI Score v1 and NSDAP Vote Share (1930) (O'Loughlin et al., 1994-2002 Data)

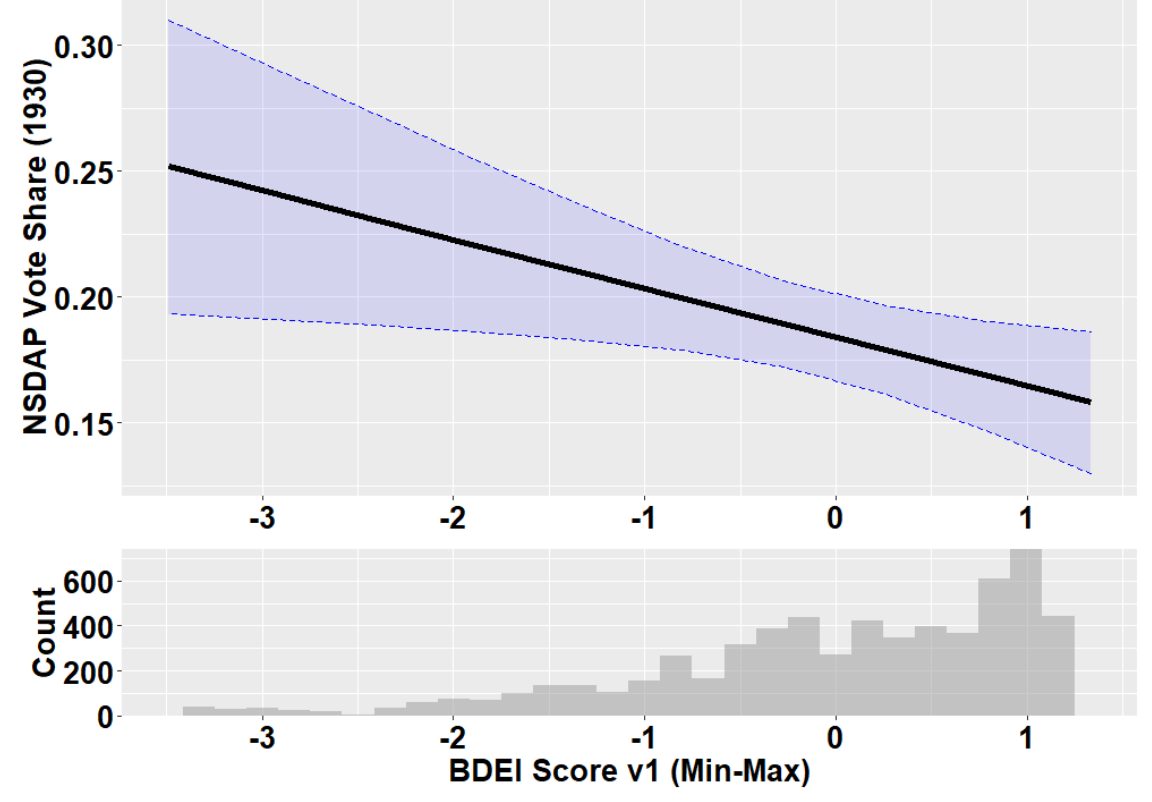

Figure A2: Predicted Values Plot: BDEI Score v1 and NSDAP Vote Share (Jul. 1932) (O’Loughlin et al., 1994-2002 Data)

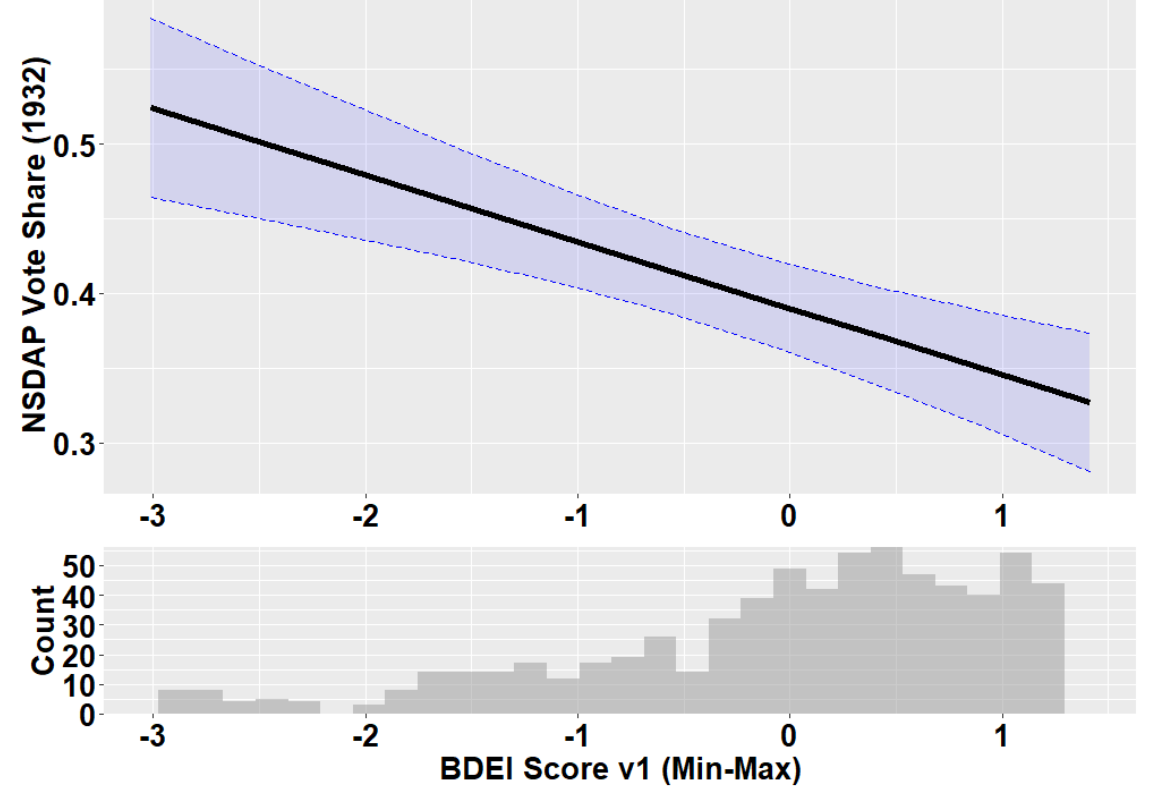


Table A25: NSDAP Vote Share (1930) (OLS) (O'Loughlin et al., 1994-2002 Data)

\begin{tabular}{|c|c|c|c|c|c|c|c|c|c|c|}
\hline & \multicolumn{10}{|c|}{ Dependent variable: } \\
\hline & & & & & NSDAP & Share (1930 & & & & \\
\hline & $(1)$ & $(2)$ & $(3)$ & $(4)$ & $(5)$ & $(6)$ & $(7)$ & $(8)$ & $(9)$ & $(10)$ \\
\hline BDEI Score v1 & $\begin{array}{c}-0.018^{* * *} \\
(0.005)\end{array}$ & & & & & $\begin{array}{c}-0.034^{* * *} \\
(0.008)\end{array}$ & & & & \\
\hline BDEI Score v2 & & $\begin{array}{c}-0.018^{* * *} \\
(0.005)\end{array}$ & & & & & $\begin{array}{c}-0.032^{* * *} \\
(0.008)\end{array}$ & & & \\
\hline BDEI Score v3 & & & $\begin{array}{c}-0.018^{* * *} \\
(0.005)\end{array}$ & & & & & $\begin{array}{c}-0.031^{* * *} \\
(0.008)\end{array}$ & & \\
\hline BDEI Score v4 & & & & $\begin{array}{c}-0.017^{* * *} \\
(0.006)\end{array}$ & & & & & $\begin{array}{c}-0.031^{* * *} \\
(0.008)\end{array}$ & \\
\hline BDEI Score v5 & & & & & $\begin{array}{c}-0.016^{* * *} \\
(0.006)\end{array}$ & & & & & $\begin{array}{c}-0.030^{* * *} \\
(0.008)\end{array}$ \\
\hline Urb. Dens. 1300 & & & & & & $\begin{array}{c}0.025^{* *} \\
(0.012)\end{array}$ & $\begin{array}{c}0.023^{*} \\
(0.012)\end{array}$ & $\begin{array}{l}0.023^{*} \\
(0.012)\end{array}$ & $\begin{array}{c}0.023^{* *} \\
(0.012)\end{array}$ & $\begin{array}{l}0.024^{*} \\
(0.012)\end{array}$ \\
\hline Dist. Maj. Port & & & & & & $\begin{array}{l}0.0002^{*} \\
(0.0001)\end{array}$ & $\begin{array}{l}0.0002^{*} \\
(0.0001)\end{array}$ & $\begin{array}{l}0.0002^{*} \\
(0.0001)\end{array}$ & $\begin{array}{l}0.0002^{*} \\
(0.0001)\end{array}$ & $\begin{array}{l}0.0002^{*} \\
(0.0001)\end{array}$ \\
\hline Dist. Trade City & & & & & & $\begin{array}{l}-0.0001 \\
(0.0001)\end{array}$ & $\begin{array}{l}-0.0001 \\
(0.0001)\end{array}$ & $\begin{array}{l}-0.0001 \\
(0.0001)\end{array}$ & $\begin{array}{l}-0.0001 \\
(0.0001)\end{array}$ & $\begin{array}{l}-0.0001 \\
(0.0001)\end{array}$ \\
\hline Dist. Ocean & & & & & & $\begin{array}{c}-0.0004^{* * *} \\
(0.0001)\end{array}$ & $\begin{array}{c}-0.0004^{* * *} \\
(0.0001)\end{array}$ & $\begin{array}{c}-0.0004^{* * *} \\
(0.0001)\end{array}$ & $\begin{array}{c}-0.0004^{* * *} \\
(0.0001)\end{array}$ & $\begin{array}{c}-0.0004^{* * *} \\
(0.0001)\end{array}$ \\
\hline Dist. River & & & & & & $\begin{array}{c}-0.00002 \\
(0.0001)\end{array}$ & $\begin{array}{c}-0.00002 \\
(0.0001)\end{array}$ & $\begin{array}{c}-0.00001 \\
(0.0001)\end{array}$ & $\begin{array}{c}-0.00001 \\
(0.0001)\end{array}$ & $\begin{array}{c}0.00000 \\
(0.0001)\end{array}$ \\
\hline Elevation & & & & & & $\begin{array}{c}0.00004 \\
(0.00003)\end{array}$ & $\begin{array}{c}0.00004 \\
(0.00003)\end{array}$ & $\begin{array}{c}0.00004 \\
(0.00003)\end{array}$ & $\begin{array}{c}0.00004 \\
(0.00003)\end{array}$ & $\begin{array}{c}0.00003 \\
(0.00003)\end{array}$ \\
\hline Constant & $\begin{array}{c}0.190^{* * *} \\
(0.006)\end{array}$ & $\begin{array}{c}0.190^{* * *} \\
(0.006)\end{array}$ & $\begin{array}{c}0.190^{* * *} \\
(0.006)\end{array}$ & $\begin{array}{c}0.190^{* * *} \\
(0.006)\end{array}$ & $\begin{array}{c}0.190^{* * *} \\
(0.006)\end{array}$ & $\begin{array}{c}0.239^{* * *} \\
(0.016)\end{array}$ & $\begin{array}{c}0.239^{* * *} \\
(0.016)\end{array}$ & $\begin{array}{c}0.239^{* * *} \\
(0.016)\end{array}$ & $\begin{array}{c}0.239^{* * *} \\
(0.017)\end{array}$ & $\begin{array}{c}0.237^{* * *} \\
(0.017) \\
\end{array}$ \\
\hline Observations & 705 & 705 & 705 & 705 & 705 & 702 & 702 & 702 & 702 & 702 \\
\hline $\mathrm{R}^{2}$ & 0.047 & 0.047 & 0.046 & 0.043 & 0.036 & 0.134 & 0.135 & 0.135 & 0.133 & 0.128 \\
\hline Adjusted $\mathrm{R}^{2}$ & 0.046 & 0.046 & 0.045 & 0.041 & 0.035 & 0.125 & 0.126 & 0.126 & 0.124 & 0.119 \\
\hline
\end{tabular}


Table A26: NSDAP Vote Share (Jul. 1932) (OLS) (O'Loughlin et al., 1994-2002 Data)

\begin{tabular}{|c|c|c|c|c|c|c|c|c|c|c|}
\hline & \multicolumn{10}{|c|}{ Dependent variable: } \\
\hline & \multicolumn{10}{|c|}{ NSDAP Vote Share (Jul. 1932) } \\
\hline & $(1)$ & $(2)$ & $(3)$ & $(4)$ & $(5)$ & $(6)$ & $(7)$ & $(8)$ & $(9)$ & $(10)$ \\
\hline BDEI Score v1 & $\begin{array}{c}-0.045^{* * *} \\
(0.010)\end{array}$ & & & & & $\begin{array}{c}-0.105^{* * *} \\
(0.019)\end{array}$ & & & & \\
\hline BDEI Score v2 & & $\begin{array}{c}-0.046^{* * *} \\
(0.010)\end{array}$ & & & & & $\begin{array}{c}-0.099^{* * *} \\
(0.017)\end{array}$ & & & \\
\hline BDEI Score v3 & & & $\begin{array}{c}-0.046^{* * *} \\
(0.010)\end{array}$ & & & & & $\begin{array}{c}-0.100^{* * *} \\
(0.016)\end{array}$ & & \\
\hline BDEI Score v4 & & & & $\begin{array}{c}-0.045^{* * *} \\
(0.011)\end{array}$ & & & & & $\begin{array}{c}-0.104^{* * *} \\
(0.016)\end{array}$ & \\
\hline BDEI Score v5 & & & & & $\begin{array}{c}-0.043^{* * *} \\
(0.011)\end{array}$ & & & & & $\begin{array}{c}-0.106^{* * *} \\
(0.016)\end{array}$ \\
\hline Urb. Dens. 1300 & & & & & & $\begin{array}{c}0.103^{* * *} \\
(0.027)\end{array}$ & $\begin{array}{c}0.096^{* * *} \\
(0.026)\end{array}$ & $\begin{array}{c}0.097^{* * *} \\
(0.026)\end{array}$ & $\begin{array}{c}0.103^{* * *} \\
(0.026)\end{array}$ & $\begin{array}{c}0.109^{* * *} \\
(0.028)\end{array}$ \\
\hline Dist. Maj. Port & & & & & & $\begin{array}{l}0.001^{* * *} \\
(0.0003)\end{array}$ & $\begin{array}{l}0.001^{* * *} \\
(0.0003)\end{array}$ & $\begin{array}{l}0.001^{* * *} \\
(0.0003)\end{array}$ & $\begin{array}{l}0.001^{* * *} \\
(0.0003)\end{array}$ & $\begin{array}{l}0.001^{* * * *} \\
(0.0003)\end{array}$ \\
\hline Dist. Trade City & & & & & & $\begin{array}{l}-0.0001 \\
(0.0002)\end{array}$ & $\begin{array}{l}-0.0001 \\
(0.0002)\end{array}$ & $\begin{array}{l}-0.0001 \\
(0.0002)\end{array}$ & $\begin{array}{l}-0.0001 \\
(0.0002)\end{array}$ & $\begin{array}{c}-0.00003 \\
(0.0002)\end{array}$ \\
\hline Dist. Ocean & & & & & & $\begin{array}{c}-0.001^{* * *} \\
(0.0002)\end{array}$ & $\begin{array}{c}-0.001^{* * *} \\
(0.0002)\end{array}$ & $\begin{array}{c}-0.001^{* * *} \\
(0.0002)\end{array}$ & $\begin{array}{c}-0.001^{* * *} \\
(0.0002)\end{array}$ & $\begin{array}{c}-0.001^{* * *} \\
(0.0002)\end{array}$ \\
\hline Dist. River & & & & & & $\begin{array}{l}-0.0002 \\
(0.0002)\end{array}$ & $\begin{array}{l}-0.0002 \\
(0.0002)\end{array}$ & $\begin{array}{l}-0.0002 \\
(0.0002)\end{array}$ & $\begin{array}{l}-0.0002 \\
(0.0002)\end{array}$ & $\begin{array}{l}-0.0002 \\
(0.0002)\end{array}$ \\
\hline Elevation & & & & & & $\begin{array}{c}0.0002^{* * *} \\
(0.0001)\end{array}$ & $\begin{array}{c}0.0002^{* * *} \\
(0.0001)\end{array}$ & $\begin{array}{c}0.0002^{* * *} \\
(0.0001)\end{array}$ & $\begin{array}{c}0.0002^{* * *} \\
(0.0001)\end{array}$ & $\begin{array}{c}0.0002^{* * *} \\
(0.0001)\end{array}$ \\
\hline Constant & $\begin{array}{c}0.390^{* * *} \\
(0.015)\end{array}$ & $\begin{array}{c}0.390^{* * *} \\
(0.015)\end{array}$ & $\begin{array}{c}0.390^{* * *} \\
(0.015)\end{array}$ & $\begin{array}{c}0.390^{* * *} \\
(0.015)\end{array}$ & $\begin{array}{c}0.390^{* * *} \\
(0.015)\end{array}$ & $\begin{array}{c}0.491^{* * *} \\
(0.028) \\
\end{array}$ & $\begin{array}{c}0.491^{* * *} \\
(0.027) \\
\end{array}$ & $\begin{array}{c}0.492^{* * *} \\
(0.027) \\
\end{array}$ & $\begin{array}{c}0.494^{* * *} \\
(0.027) \\
\end{array}$ & $\begin{array}{c}0.494^{* * *} \\
(0.028) \\
\end{array}$ \\
\hline Observations & 705 & 705 & 705 & 705 & 705 & 702 & 702 & 702 & 702 & 702 \\
\hline $\mathrm{R}^{2}$ & 0.095 & 0.100 & 0.102 & 0.098 & 0.089 & 0.264 & 0.269 & 0.276 & 0.281 & 0.278 \\
\hline Adjusted $\mathrm{R}^{2}$ & 0.094 & 0.098 & 0.101 & 0.097 & 0.087 & 0.257 & 0.261 & 0.268 & 0.274 & 0.271 \\
\hline
\end{tabular}


Table A27: NSDAP Vote Share (1930) (Tobit) (O'Louglin et al., 1994-2002 Data)

\begin{tabular}{|c|c|c|c|c|c|c|c|c|c|c|}
\hline & \multicolumn{10}{|c|}{ Dependent variable: } \\
\hline & & & & & NSDAP & Share (193 & & & & \\
\hline & $(1)$ & $(2)$ & $(3)$ & $(4)$ & $(5)$ & $(6)$ & $(7)$ & $(8)$ & $(9)$ & $(10)$ \\
\hline BDEI Score v1 & $\begin{array}{c}-0.018^{* * *} \\
(0.003)\end{array}$ & & & & & $\begin{array}{c}-0.034^{* * *} \\
(0.005)\end{array}$ & & & & \\
\hline BDEI Score v2 & & $\begin{array}{c}-0.018^{* * *} \\
(0.003)\end{array}$ & & & & & $\begin{array}{c}-0.032^{* * *} \\
(0.005)\end{array}$ & & & \\
\hline BDEI Score v3 & & & $\begin{array}{c}-0.018^{* * *} \\
(0.003)\end{array}$ & & & & & $\begin{array}{c}-0.031^{* * *} \\
(0.005)\end{array}$ & & \\
\hline BDEI Score v4 & & & & $\begin{array}{c}-0.017^{* * *} \\
(0.003)\end{array}$ & & & & & $\begin{array}{c}-0.031^{* * *} \\
(0.005)\end{array}$ & \\
\hline BDEI Score v5 & & & & & $\begin{array}{c}-0.016^{* * *} \\
(0.003)\end{array}$ & & & & & $\begin{array}{c}-0.030^{* * *} \\
(0.005)\end{array}$ \\
\hline Urb. Dens. 1300 & & & & & & $\begin{array}{c}0.025^{* * *} \\
(0.008)\end{array}$ & $\begin{array}{c}0.023^{* * *} \\
(0.008)\end{array}$ & $\begin{array}{c}0.023^{* * *} \\
(0.008)\end{array}$ & $\begin{array}{c}0.023^{* * *} \\
(0.008)\end{array}$ & $\begin{array}{c}0.024^{* * *} \\
(0.008)\end{array}$ \\
\hline Dist. Maj. Port & & & & & & $\begin{array}{c}0.0002^{* * *} \\
(0.0001)\end{array}$ & $\begin{array}{c}0.0002^{* *} \\
(0.0001)\end{array}$ & $\begin{array}{l}0.0002^{* *} \\
(0.0001)\end{array}$ & $\begin{array}{c}0.0002^{* *} \\
(0.0001)\end{array}$ & $\begin{array}{c}0.0002^{* *} \\
(0.0001)\end{array}$ \\
\hline Dist. Trade City & & & & & & $\begin{array}{c}-0.0001^{*} \\
(0.0001)\end{array}$ & $\begin{array}{l}-0.0001 \\
(0.0001)\end{array}$ & $\begin{array}{l}-0.0001 \\
(0.0001)\end{array}$ & $\begin{array}{l}-0.0001 \\
(0.0001)\end{array}$ & $\begin{array}{l}-0.0001 \\
(0.0001)\end{array}$ \\
\hline Dist. Ocean & & & & & & $\begin{array}{c}-0.0004^{* * *} \\
(0.0001)\end{array}$ & $\begin{array}{c}-0.0004^{* * *} \\
(0.0001)\end{array}$ & $\begin{array}{c}-0.0004^{* * *} \\
(0.0001)\end{array}$ & $\begin{array}{c}-0.0004^{* * *} \\
(0.0001)\end{array}$ & $\begin{array}{c}-0.0004^{* * *} \\
(0.0001)\end{array}$ \\
\hline Dist. River & & & & & & $\begin{array}{c}-0.00002 \\
(0.0001)\end{array}$ & $\begin{array}{c}-0.00002 \\
(0.0001)\end{array}$ & $\begin{array}{c}-0.00001 \\
(0.0001)\end{array}$ & $\begin{array}{c}-0.00001 \\
(0.0001)\end{array}$ & $\begin{array}{c}0.00000 \\
(0.0001)\end{array}$ \\
\hline Elevation & & & & & & $\begin{array}{c}0.00004 \\
(0.00002)\end{array}$ & $\begin{array}{c}0.00004 \\
(0.00002)\end{array}$ & $\begin{array}{c}0.00004 \\
(0.00002)\end{array}$ & $\begin{array}{c}0.00004 \\
(0.00003)\end{array}$ & $\begin{array}{c}0.00003 \\
(0.00003)\end{array}$ \\
\hline Constant & $\begin{array}{c}0.190^{* * *} \\
(0.003) \\
\end{array}$ & $\begin{array}{c}0.190^{* * *} \\
(0.003) \\
\end{array}$ & $\begin{array}{c}0.190^{* * *} \\
(0.003)\end{array}$ & $\begin{array}{c}0.190^{* * *} \\
(0.003) \\
\end{array}$ & $\begin{array}{c}0.190^{* * *} \\
(0.003) \\
\end{array}$ & $\begin{array}{c}0.239^{* * *} \\
(0.010)\end{array}$ & $\begin{array}{c}0.239^{* * *} \\
(0.010)\end{array}$ & $\begin{array}{c}0.239^{* * *} \\
(0.010)\end{array}$ & $\begin{array}{c}0.239^{* * *} \\
(0.010)\end{array}$ & $\begin{array}{c}0.237^{* * *} \\
(0.010)\end{array}$ \\
\hline Observations & 705 & 705 & 705 & 705 & 705 & 702 & 702 & 702 & 702 & 702 \\
\hline Log Likelihood & 773.427 & 773.447 & 773.152 & 771.811 & 769.394 & 802.439 & 802.936 & 803.051 & 802.237 & 799.954 \\
\hline
\end{tabular}


Table A28: NSDAP Vote Share (Jul. 1932) (Tobit) (O'Louglin et al., 1994-2002 Data)

\begin{tabular}{|c|c|c|c|c|c|c|c|c|c|c|}
\hline & \multicolumn{10}{|c|}{ Dependent variable: } \\
\hline & \multicolumn{10}{|c|}{ NSDAP Vote Share (Jul. 1932) } \\
\hline & $(1)$ & $(2)$ & $(3)$ & $(4)$ & $(5)$ & $(6)$ & $(7)$ & $(8)$ & $(9)$ & $(10)$ \\
\hline BDEI Score v1 & $\begin{array}{c}-0.045^{* * *} \\
(0.005)\end{array}$ & & & & & $\begin{array}{c}-0.105^{* * *} \\
(0.009)\end{array}$ & & & & \\
\hline BDEI Score v2 & & $\begin{array}{c}-0.046^{* * *} \\
(0.005)\end{array}$ & & & & & $\begin{array}{c}-0.099^{* * *} \\
(0.008)\end{array}$ & & & \\
\hline BDEI Score v3 & & & $\begin{array}{c}-0.046^{* * *} \\
(0.005)\end{array}$ & & & & & $\begin{array}{c}-0.100^{* * *} \\
(0.008)\end{array}$ & & \\
\hline BDEI Score v4 & & & & $\begin{array}{c}-0.045^{* * *} \\
(0.005)\end{array}$ & & & & & $\begin{array}{c}-0.104^{* * *} \\
(0.008)\end{array}$ & \\
\hline BDEI Score v5 & & & & & $\begin{array}{c}-0.043^{* * *} \\
(0.005)\end{array}$ & & & & & $\begin{array}{c}-0.106^{* * *} \\
(0.008)\end{array}$ \\
\hline Urb. Dens. 1300 & & & & & & $\begin{array}{c}0.103^{* * *} \\
(0.013)\end{array}$ & $\begin{array}{c}0.096^{* * *} \\
(0.012)\end{array}$ & $\begin{array}{c}0.097^{* * *} \\
(0.012)\end{array}$ & $\begin{array}{c}0.103^{* * *} \\
(0.012)\end{array}$ & $\begin{array}{c}0.109^{* * *} \\
(0.012)\end{array}$ \\
\hline Dist. Maj. Port & & & & & & $\begin{array}{l}0.001^{* * *} \\
(0.0001)\end{array}$ & $\begin{array}{c}0.001^{* * *} \\
(0.0001)\end{array}$ & $\begin{array}{c}0.001^{* * *} \\
(0.0001)\end{array}$ & $\begin{array}{c}0.001^{* * *} \\
(0.0001)\end{array}$ & $\begin{array}{c}0.001^{* * *} \\
(0.0001)\end{array}$ \\
\hline Dist. Trade City & & & & & & $\begin{array}{l}-0.0001 \\
(0.0001)\end{array}$ & $\begin{array}{l}-0.0001 \\
(0.0001)\end{array}$ & $\begin{array}{l}-0.0001 \\
(0.0001)\end{array}$ & $\begin{array}{l}-0.0001 \\
(0.0001)\end{array}$ & $\begin{array}{c}-0.00003 \\
(0.0001)\end{array}$ \\
\hline Dist. Ocean & & & & & & $\begin{array}{c}-0.001^{* * *} \\
(0.0001)\end{array}$ & $\begin{array}{c}-0.001^{* * *} \\
(0.0001)\end{array}$ & $\begin{array}{c}-0.001^{* * *} \\
(0.0001)\end{array}$ & $\begin{array}{c}-0.001^{* * *} \\
(0.0001)\end{array}$ & $\begin{array}{c}-0.001^{* * *} \\
(0.0001)\end{array}$ \\
\hline Dist. River & & & & & & $\begin{array}{c}-0.0002^{*} \\
(0.0001)\end{array}$ & $\begin{array}{l}-0.0002 \\
(0.0001)\end{array}$ & $\begin{array}{l}-0.0002 \\
(0.0001)\end{array}$ & $\begin{array}{l}-0.0002 \\
(0.0001)\end{array}$ & $\begin{array}{l}-0.0002 \\
(0.0001)\end{array}$ \\
\hline Elevation & & & & & & $\begin{array}{l}0.0002^{* * *} \\
(0.00004)\end{array}$ & $\begin{array}{c}0.0002^{* * *} \\
(0.00004)\end{array}$ & $\begin{array}{c}0.0002^{* * *} \\
(0.00004)\end{array}$ & $\begin{array}{c}0.0002^{* * *} \\
(0.00004)\end{array}$ & $\begin{array}{c}0.0002^{* * *} \\
(0.00004)\end{array}$ \\
\hline Constant & $\begin{array}{c}0.390^{* * *} \\
(0.005) \\
\end{array}$ & $\begin{array}{c}0.390^{* * *} \\
(0.005) \\
\end{array}$ & $\begin{array}{c}0.390^{* * *} \\
(0.005) \\
\end{array}$ & $\begin{array}{c}0.390^{* * *} \\
(0.005) \\
\end{array}$ & $\begin{array}{c}0.390^{* * *} \\
(0.005) \\
\end{array}$ & $\begin{array}{c}0.491^{* * *} \\
(0.016) \\
\end{array}$ & $\begin{array}{c}0.491^{* * *} \\
(0.016) \\
\end{array}$ & $\begin{array}{c}0.492^{* * *} \\
(0.015) \\
\end{array}$ & $\begin{array}{c}0.494^{* * *} \\
(0.015) \\
\end{array}$ & $\begin{array}{c}0.494^{* * *} \\
(0.016) \\
\end{array}$ \\
\hline Observations & 705 & 705 & 705 & 705 & 705 & 702 & 702 & 702 & 702 & 702 \\
\hline Log Likelihood & 399.563 & 401.270 & 402.127 & 400.748 & 396.908 & 470.963 & 473.184 & 476.652 & 479.381 & 477.842 \\
\hline
\end{tabular}




\section{A.20 Pre-Reformation Germany: Descriptive Summary Statistics}

Table A29 shows descriptive summary statistics for towns in pre-Reformation Germany.

Table A29: Descriptive Statistics: Pre-Reformation Germany

\begin{tabular}{lrrrrrrrr} 
Variable & $\mathbf{n}$ & $\mathbf{M i n}$ & $\mathbf{q} \mathbf{1}$ & $\mathbf{\mathbf { x }}$ & $\widetilde{\mathbf{x}}$ & $\mathbf{q}_{\mathbf{3}}$ & $\mathbf{M a x}$ & $\mathbf{I Q R}$ \\
\hline BDEI Score v1 & 325 & -2.78 & -0.71 & 0.00 & 0.18 & 0.86 & 1.92 & 1.57 \\
BDEI Score v2 & 325 & -2.52 & -0.72 & 0.00 & 0.12 & 0.79 & 2.45 & 1.52 \\
BDEI Score v3 & 325 & -2.46 & -0.69 & 0.00 & 0.10 & 0.73 & 3.01 & 1.42 \\
BDEI Score v4 & 325 & -2.52 & -0.63 & 0.00 & 0.15 & 0.62 & 3.51 & 1.24 \\
BDEI Score v5 & 325 & -2.65 & -0.52 & 0.00 & 0.21 & 0.52 & 3.87 & 1.05 \\
Introduction of Participative & 325 & 0.00 & 0.00 & 0.15 & 0.00 & 0.00 & 1.00 & 0.00 \\
$\quad$ Elections (1300-1500) & & & & & & & & \\
Occurrence of Participative & 325 & 0.00 & 0.00 & 0.24 & 0.00 & 0.00 & 1.00 & 0.00 \\
$\quad$ Elections (1500) & & & & & & & \\
Elevation & 86 & 2.72 & 79.33 & 227.90 & 187.22 & 357.24 & 852.91 & 277.91 \\
Dist. to River & 86 & 0.13 & 12.69 & 51.90 & 50.53 & 78.28 & 143.05 & 65.59 \\
Roman Road & 86 & 0.00 & 0.00 & 0.26 & 0.00 & 0.75 & 1.00 & 0.75 \\
Coast & 86 & 0.00 & 0.00 & 0.08 & 0.00 & 0.00 & 1.00 & 0.00 \\
Agricultural Suitability & 86 & 0.00 & 19.25 & 35.91 & 37.33 & 50.42 & 69.27 & 31.17 \\
Population (Log) & 86 & 6.91 & 7.70 & 8.57 & 8.70 & 9.28 & 10.90 & 1.58 \\
Ruggedness & 86 & 2.21 & 11.14 & 34.75 & 25.91 & 46.03 & 342.94 & 34.89 \\
Urban Potential 1300 & 86 & 2252.19 & 4437.69 & 5147.74 & 4998.34 & 5852.00 & 8224.76 & 1414.31 \\
Trade City 1300 & 86 & 0.00 & 0.00 & 0.06 & 0.00 & 0.00 & 1.00 & 0.00 \\
Proto-Industrial City 1300 & 86 & 0.00 & 0.00 & 0.05 & 0.00 & 0.00 & 1.00 & 0.00
\end{tabular}




\section{A.21 Pre-Reformation Germany: Measuring the 'Occurrence of' Instead of 'Changes in' Participative Elections}

In our main empirical analysis of the suggested mechanisms in pre-Reformation Germany, we measure changes in participative elections between 1300 and 1500. In addition to this main analysis, it would be worthwhile to investigate if the mere occurrence of participative elections in the year 1500 can also shown to be spatially associated with Black Death intensities. Accordingly, in Table A30 and Table A31, we show the results of such an analysis. The results hold. Furthermore, in some cases, they are even stronger than in our initial analysis. All details can be found in the tables below.

Table A30: Occurrence of Participative Elections (1500) (Logit)

\begin{tabular}{|c|c|c|c|c|c|}
\hline & \multicolumn{5}{|c|}{ Dependent variable: } \\
\hline & \multicolumn{5}{|c|}{ Occurrence of Participative Elections (1500) } \\
\hline & $(1)$ & $(2)$ & $(3)$ & $(4)$ & $(5)$ \\
\hline BDEI Score v1 & $\begin{array}{c}0.748^{* * *} \\
(0.162)\end{array}$ & & & & \\
\hline BDEI Score v2 & & $\begin{array}{c}0.699^{* * *} \\
(0.154)\end{array}$ & & & \\
\hline BDEI Score v3 & & & $\begin{array}{c}0.643^{* * *} \\
(0.149)\end{array}$ & & \\
\hline BDEI Score v4 & & & & $\begin{array}{c}0.585^{* * *} \\
(0.147)\end{array}$ & \\
\hline BDEI Score v5 & & & & & $\begin{array}{c}0.519^{* * *} \\
(0.145)\end{array}$ \\
\hline Constant & $\begin{array}{c}-1.292^{* * *} \\
(0.147) \\
\end{array}$ & $\begin{array}{c}-1.273^{* * *} \\
(0.144) \\
\end{array}$ & $\begin{array}{c}-1.253^{* * *} \\
(0.141) \\
\end{array}$ & $\begin{array}{c}-1.234^{* * *} \\
(0.139) \\
\end{array}$ & $\begin{array}{c}-1.217^{* * *} \\
(0.137) \\
\end{array}$ \\
\hline Observations & 325 & 325 & 325 & 325 & 325 \\
\hline Log Likelihood & -166.325 & -167.132 & -168.505 & -170.145 & -171.960 \\
\hline Akaike Inf. Crit. & 336.650 & 338.265 & 341.011 & 344.291 & 347.919 \\
\hline
\end{tabular}


Table A31: Occurrence of Participative Elections (1500) (Logit)

\begin{tabular}{|c|c|c|c|c|c|}
\hline & \multicolumn{5}{|c|}{ Dependent variable: } \\
\hline & \multicolumn{5}{|c|}{ Occurrence of Participative Elections (1500) } \\
\hline & (1) & $(2)$ & $(3)$ & $(4)$ & (5) \\
\hline BDEI Score v1 & $\begin{array}{c}3.411^{* * *} \\
(1.130)\end{array}$ & & & & \\
\hline BDEI Score v2 & & $\begin{array}{c}3.148^{* * *} \\
(1.057)\end{array}$ & & & \\
\hline BDEI Score v3 & & & $\begin{array}{c}2.719^{* * *} \\
(0.947)\end{array}$ & & \\
\hline BDEI Score v4 & & & & $\begin{array}{c}2.089^{* * *} \\
(0.792)\end{array}$ & \\
\hline BDEI Score v 5 & & & & & $\begin{array}{l}1.444^{* *} \\
(0.635)\end{array}$ \\
\hline Elevation & $\begin{array}{l}-0.004 \\
(0.003)\end{array}$ & $\begin{array}{l}-0.003 \\
(0.003)\end{array}$ & $\begin{array}{c}-0.003 \\
(0.003)\end{array}$ & $\begin{array}{l}-0.001 \\
(0.003)\end{array}$ & $\begin{array}{c}-0.0001 \\
(0.003)\end{array}$ \\
\hline Distance to River & $\begin{array}{l}0.020^{* *} \\
(0.009)\end{array}$ & $\begin{array}{c}0.021^{* *} \\
(0.009)\end{array}$ & $\begin{array}{c}0.021^{* *} \\
(0.009)\end{array}$ & $\begin{array}{l}0.020^{* *} \\
(0.009)\end{array}$ & $\begin{array}{l}0.019^{* *} \\
(0.008)\end{array}$ \\
\hline Roman Road & $\begin{array}{c}-1.742^{*} \\
(1.051)\end{array}$ & $\begin{array}{l}-1.593 \\
(1.018)\end{array}$ & $\begin{array}{l}-1.334 \\
(0.971)\end{array}$ & $\begin{array}{r}-0.985 \\
(0.916)\end{array}$ & $\begin{array}{l}-0.705 \\
(0.883)\end{array}$ \\
\hline Coast & $\begin{array}{c}-19.108 \\
(2,213.812)\end{array}$ & $\begin{array}{c}-19.082 \\
(2,267.928)\end{array}$ & $\begin{array}{c}-17.865 \\
(1,404.991)\end{array}$ & $\begin{array}{c}-17.534 \\
(1,426.443)\end{array}$ & $\begin{array}{c}-17.239 \\
(1,439.656)\end{array}$ \\
\hline Agricult. Suit. & $\begin{array}{c}0.020 \\
(0.019)\end{array}$ & $\begin{array}{c}0.022 \\
(0.019)\end{array}$ & $\begin{array}{c}0.022 \\
(0.019)\end{array}$ & $\begin{array}{c}0.020 \\
(0.019)\end{array}$ & $\begin{array}{c}0.017 \\
(0.018)\end{array}$ \\
\hline Population (Log.) & $\begin{array}{l}-0.292 \\
(0.391)\end{array}$ & $\begin{array}{l}-0.257 \\
(0.387)\end{array}$ & $\begin{array}{l}-0.212 \\
(0.381)\end{array}$ & $\begin{array}{l}-0.177 \\
(0.376)\end{array}$ & $\begin{array}{l}-0.153 \\
(0.371)\end{array}$ \\
\hline Ruggedness & $\begin{array}{c}-0.044^{* *} \\
(0.020)\end{array}$ & $\begin{array}{c}-0.045^{* *} \\
(0.021)\end{array}$ & $\begin{array}{c}-0.045^{* *} \\
(0.021)\end{array}$ & $\begin{array}{c}-0.044^{* *} \\
(0.020)\end{array}$ & $\begin{array}{c}-0.042^{* *} \\
(0.020)\end{array}$ \\
\hline Urban Potential 1300 & $\begin{array}{c}-0.001^{*} \\
(0.001)\end{array}$ & $\begin{array}{c}-0.001^{*} \\
(0.001)\end{array}$ & $\begin{array}{l}-0.001 \\
(0.001)\end{array}$ & $\begin{array}{l}-0.0003 \\
(0.0005)\end{array}$ & $\begin{array}{c}0.0001 \\
(0.0004)\end{array}$ \\
\hline Trade City 1300 & $\begin{array}{l}-4.135 \\
(2.605)\end{array}$ & $\begin{array}{l}-3.973 \\
(2.496)\end{array}$ & $\begin{array}{l}-3.721 \\
(2.328)\end{array}$ & $\begin{array}{l}-3.376 \\
(2.157)\end{array}$ & $\begin{array}{l}-3.041 \\
(2.044)\end{array}$ \\
\hline Proto-Indust. City 1300 & $\begin{array}{c}4.123 \\
(2.607)\end{array}$ & $\begin{array}{c}4.104 \\
(2.521)\end{array}$ & $\begin{array}{l}3.906 \\
(2.381)\end{array}$ & $\begin{array}{c}3.506 \\
(2.232)\end{array}$ & $\begin{array}{c}3.051 \\
(2.124)\end{array}$ \\
\hline Constant & $\begin{array}{l}9.407^{*} \\
(5.660) \\
\end{array}$ & $\begin{array}{l}7.960 \\
(5.326) \\
\end{array}$ & $\begin{array}{c}5.437 \\
(4.780) \\
\end{array}$ & $\begin{array}{c}2.286 \\
(4.179) \\
\end{array}$ & $\begin{array}{l}-0.416 \\
(3.759) \\
\end{array}$ \\
\hline Observations & 86 & 86 & 86 & 86 & 86 \\
\hline Log Likelihood & -32.137 & -32.365 & -32.947 & -34.005 & -35.237 \\
\hline Akaike Inf. Crit. & 88.274 & 88.729 & 89.894 & 92.010 & 94.474 \\
\hline
\end{tabular}




\section{A.22 Early Nineteenth-Century Prussia: Descriptive Summary Statistics}

Table A.1 shows descriptive summary statistics for early nineteenth-century Prussia.

Table A32: Descriptive Statistics: Early Nineteenth-Century Prussia

\begin{tabular}{|c|c|c|c|c|c|c|c|c|}
\hline Variable & $\mathbf{n}$ & Min & $\mathbf{q}_{1}$ & $\overline{\mathbf{x}}$ & $\widetilde{\mathbf{x}}$ & $\mathbf{q}_{3}$ & $\operatorname{Max}$ & IQR \\
\hline BDEI Score v1 & 280 & -2.06 & -0.83 & 0.00 & -0.11 & 1.06 & 1.44 & 1.88 \\
\hline BDEI Score v2 & 280 & -1.75 & -0.88 & 0.00 & -0.17 & 1.08 & 1.51 & 1.96 \\
\hline BDEI Score v3 & 280 & -1.63 & -0.91 & 0.00 & -0.15 & 1.07 & 1.53 & 1.99 \\
\hline BDEI Score v4 & 280 & -1.58 & -0.96 & 0.00 & -0.09 & 1.07 & 1.49 & 2.03 \\
\hline BDEI Score v5 & 280 & -1.56 & -1.00 & 0.00 & -0.02 & 1.05 & 1.41 & 2.05 \\
\hline Proportion of Largest Farms (1816) & 267 & 0.00 & 0.00 & 0.02 & 0.01 & 0.02 & 0.15 & 0.02 \\
\hline Proportion of Agric. Servants (of Total Pop.) (1816/1819) & 280 & 0.00 & 0.07 & 0.09 & 0.09 & 0.11 & 0.24 & 0.05 \\
\hline Urban Density (Standardized) (1300) & 280 & -2.73 & -0.71 & 0.00 & 0.27 & 0.75 & 1.43 & 1.46 \\
\hline Distance to the Nearest Major Port (km) & 280 & 0.00 & 51.55 & 125.82 & 94.07 & 173.94 & 448.43 & 122.39 \\
\hline Distance to the Nearest Medieval Trade City $(\mathrm{km})$ & 280 & 0.00 & 40.14 & 110.45 & 68.81 & 141.28 & 468.84 & 101.14 \\
\hline Distance to the Ocean $(\mathrm{km})$ & 280 & 0.00 & 100.47 & 176.60 & 165.48 & 241.31 & 446.70 & 140.83 \\
\hline Distance to the Nearest Large River $(\mathrm{km})$ & 280 & 0.00 & 6.16 & 36.46 & 24.69 & 59.51 & 158.22 & 53.36 \\
\hline Elevation & 279 & 7.00 & 63.50 & 156.62 & 118.00 & 211.00 & 626.00 & 147.50 \\
\hline
\end{tabular}




\section{A.23 Early Nineteenth-Century Prussia: Tobit Models as an Al- ternative Specification}

In our main empirical analysis we use OLS regression to estimate the impact of the BDEI score on the Proportion of Large Estates (1816) and Proportion of Agricultural Servants (of Total Population) (1816/1819). Because these two outcome variables are truncated, i.e. both have an upper and lower bound, we also use Tobit models as an alternative empirical specification.

Table A33 shows the results with respect to the Proportion of Large Estates (1816) when using Tobit models. Furthermore, Table A34 shows the results with respect to Proportion of Agricultural Servants (of Total Population) (1816/1819) when using Tobit models. In both cases, the direction, magnitude, and significance of the coefficients do not change in a way that would alter our previous interpretation. 
Table A33: Proportion of Large Estates (1816) (Tobit)

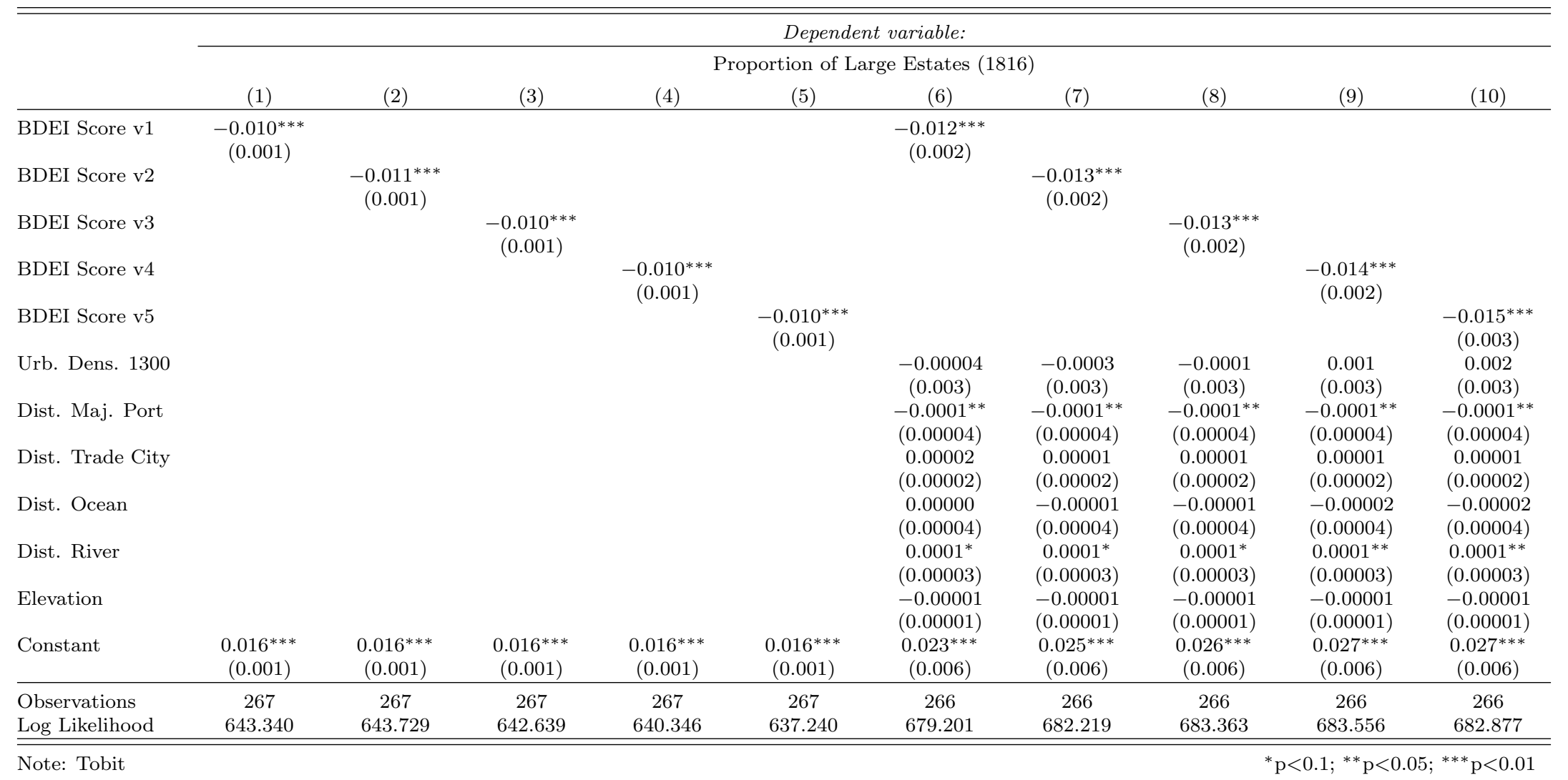


Table A34: Proportion of Agricultural Servants (of Total Population) (1816/1819) (Tobit)

\begin{tabular}{|c|c|c|c|c|c|c|c|c|c|c|}
\hline & \multicolumn{10}{|c|}{ Dependent variable: } \\
\hline & \multicolumn{10}{|c|}{ Proportion of Agricultural Servants (of Total Population) (1816/1819) } \\
\hline & $(1)$ & $(2)$ & $(3)$ & $(4)$ & $(5)$ & $(6)$ & $(7)$ & $(8)$ & $(9)$ & $(10)$ \\
\hline BDEI Score v1 & $\begin{array}{c}-0.012^{* * *} \\
(0.002)\end{array}$ & & & & & $\begin{array}{c}-0.018^{* * *} \\
(0.005)\end{array}$ & & & & \\
\hline BDEI Score v2 & & $\begin{array}{c}-0.012^{* * *} \\
(0.002)\end{array}$ & & & & & $\begin{array}{c}-0.018^{* * *} \\
(0.004)\end{array}$ & & & \\
\hline BDEI Score v3 & & & $\begin{array}{c}-0.012^{* * *} \\
(0.002)\end{array}$ & & & & & $\begin{array}{c}-0.018^{* * *} \\
(0.004)\end{array}$ & & \\
\hline BDEI Score v4 & & & & $\begin{array}{c}-0.012^{* * *} \\
(0.002)\end{array}$ & & & & & $\begin{array}{c}-0.019^{* * *} \\
(0.005)\end{array}$ & \\
\hline BDEI Score v5 & & & & & $\begin{array}{c}-0.012^{* * *} \\
(0.002)\end{array}$ & & & & & $\begin{array}{c}-0.020^{* * *} \\
(0.005)\end{array}$ \\
\hline Urb. Dens. 1300 & & & & & & $\begin{array}{c}-0.011^{* *} \\
(0.006)\end{array}$ & $\begin{array}{c}-0.013^{* *} \\
(0.005)\end{array}$ & $\begin{array}{c}-0.013^{* *} \\
(0.005)\end{array}$ & $\begin{array}{c}-0.011^{* *} \\
(0.006)\end{array}$ & $\begin{array}{c}-0.010^{*} \\
(0.006)\end{array}$ \\
\hline Dist. Maj. Port & & & & & & $\begin{array}{l}0.00002 \\
(0.0001)\end{array}$ & $\begin{array}{l}0.00002 \\
(0.0001)\end{array}$ & $\begin{array}{l}0.00002 \\
(0.0001)\end{array}$ & $\begin{array}{l}0.00002 \\
(0.0001)\end{array}$ & $\begin{array}{l}0.00002 \\
(0.0001)\end{array}$ \\
\hline Dist. Trade City & & & & & & $\begin{array}{c}-0.0003^{* * *} \\
(0.00005)\end{array}$ & $\begin{array}{c}-0.0003^{* * *} \\
(0.00005)\end{array}$ & $\begin{array}{c}-0.0003^{* * *} \\
(0.00005)\end{array}$ & $\begin{array}{c}-0.0003^{* * *} \\
(0.00005)\end{array}$ & $\begin{array}{c}-0.0003^{* * * *} \\
(0.00005)\end{array}$ \\
\hline Dist. Ocean & & & & & & $\begin{array}{c}-0.0002^{* *} \\
(0.0001)\end{array}$ & $\begin{array}{c}-0.0002^{* *} \\
(0.0001)\end{array}$ & $\begin{array}{c}-0.0002^{* * *} \\
(0.0001)\end{array}$ & $\begin{array}{c}-0.0002^{* * *} \\
(0.0001)\end{array}$ & $\begin{array}{c}-0.0002^{* * *} \\
(0.0001)\end{array}$ \\
\hline Dist. River & & & & & & $\begin{array}{l}0.00000 \\
(0.0001)\end{array}$ & $\begin{array}{l}0.00001 \\
(0.0001)\end{array}$ & $\begin{array}{l}0.00001 \\
(0.0001)\end{array}$ & $\begin{array}{l}0.00001 \\
(0.0001)\end{array}$ & $\begin{array}{c}0.00002 \\
(0.0001)\end{array}$ \\
\hline Elevation & & & & & & $\begin{array}{c}-0.0001^{* * *} \\
(0.00002)\end{array}$ & $\begin{array}{c}-0.0001^{* * *} \\
(0.00002)\end{array}$ & $\begin{array}{c}-0.0001^{* * *} \\
(0.00002)\end{array}$ & $\begin{array}{c}-0.0001^{* * *} \\
(0.00002)\end{array}$ & $\begin{array}{c}-0.0001^{* * *} \\
(0.00002)\end{array}$ \\
\hline Constant & $\begin{array}{c}0.092^{* * *} \\
(0.002) \\
\end{array}$ & $\begin{array}{c}0.092^{* * *} \\
(0.002) \\
\end{array}$ & $\begin{array}{c}0.092^{* * *} \\
(0.002) \\
\end{array}$ & $\begin{array}{c}0.092^{* * *} \\
(0.002) \\
\end{array}$ & $\begin{array}{c}0.092^{* * *} \\
(0.002) \\
\end{array}$ & $\begin{array}{c}0.160^{* * *} \\
(0.011) \\
\end{array}$ & $\begin{array}{c}0.161^{* * *} \\
(0.011) \\
\end{array}$ & $\begin{array}{c}0.161^{* * *} \\
(0.011)\end{array}$ & $\begin{array}{c}0.162^{* * *} \\
(0.011)\end{array}$ & $\begin{array}{c}0.162^{* * *} \\
(0.011)\end{array}$ \\
\hline Observations & 280 & 280 & 280 & 280 & 280 & 279 & 279 & 279 & 279 & 279 \\
\hline Log Likelihood & 528.584 & 528.386 & 528.107 & 527.831 & 527.461 & 559.608 & 560.180 & 560.395 & 560.378 & 560.010 \\
\hline
\end{tabular}




\section{A.24 Further Discussion of the Empirical Design}

In this section, we further discuss aspects of the empirical design, namely (1) our choice to focus on the plague outbreak in 1347-1351, (2) the possibility that preexisting differences in socioeconomic conditions inflate our Black Death exposure intensity estimates, and (3) reasons for not including the Free Conservative Party when analyzing political outcomes.

\section{A.24.1 The Difference Between the Initial and Subsequent Plague Outbreaks}

For several centuries after the initial outbreak of the Black Death - the event that is at the center of our study —Europeans repeatedly suffered from further plague outbreaks. Why did we limit our study and empirical design to the major outbreak that occurred in 1347-1351?

The reason for this choice is primarily a substantive one. Only the shock of 1347-1351 was of such depth, severity, and geographic extent that it led to the "tectonic" movements in political-economic equilibria that many have historians, economists, and epidemiologists have observed before us.

All subsequent outbreaks were limited in their geographic extent and/or killed a substantially smaller number of people (in many of the affected locations). ${ }^{51}$ Not only do less severe outbreaks make it more likely that external market forces restore an old political-economic equilibrium more quickly, but it is also improbable that they would lead to fundamental reconfigurations of social and political relationships as did the first wave of the Black Death. Equally important, subsequent outbreaks of the plague were anticipated, whereas the initial shock was not. The experience with the Black Death led to changes in inheritance patterns and other adaptations that cushioned the economic blow of subsequent plague recurrences. For these reasons, our focus is on the 1347-1351 episode.

\footnotetext{
${ }^{51}$ Some of the late plague outbreaks in Europe were severe as well, but they were "localized events that failed to achieve the continental reach of the first invasions" (Snowden, 2019).
} 


\section{A.24.2 The Possible Effect of Preexisting Differences in Political Institutions}

Some may argue that preexisting differences in landholding inequality and labor coercion could potentially bias the results of our study. One such argument might be that the eastern parts of German-speaking central Europe historically (i.e., pre-1347) already had significantly higher levels of labor coercion and landholding inequality, rendering the impact of the Black Death less substantial than we argue it is.

As a first response to this objection, note that at least part of such variation in initial socioeconomic structures would likely be picked up by one of the covariates that we employ in our analysis: the level of urban density in 1300. As it turns out, the coefficient on this variable is insignificant in the vast majority of specifications, indicating that regional differences in urban density in the early fourteenth century were small and cannot account for the substantial variation in socieconomic structures observed in nineteenth-century Imperial Germany.

More importantly, the objection relies on the assumption that prior to the arrival of the Black Death labor coercion and land inequality were stronger in the eastern parts of Germanspeaking central Europe than in the west. This is a dubious historical claim. Not only were the regional differences likely small, existing historiography suggests that the eastern parts of "Germany" probably had more progressive labor regimes than the western parts.

Describing conditions in the east prior to the Black Death, Carsten $(1954,88)$ writes:

The peasants' position was far better than it was in the west, and this included the native population. Class distinctions in the east were less sharp, noblemen moved into the towns and became burghers, while burghers acquired estates and village mayors held fiefs. The whole structure of society, as might be expected of a colonial area, was much freer and looser than it was in western Europe.

This more favorable context for laborers was tied to the relatively recent colonization of 
the east by German speakers. As explained by Carsten $(1954,38)$ :

The fact that the German villages [in the east] as a rule were founded 'from wild root' explained, in the opinion of a legal commentator of the early fourteenth century, that the peasants had better rights in Brandenburg than they had in Saxony, that they could freely sell and leave their farms, that they had a 'heritage' which was better than leasehold, as they had improved their holdings with their own work.

In short, the high level of labor coercion and landholding inequality that existed in Prussia in the centuries preceding the German Empire was not a feature of these regions in the period prior to the Black Death. Rather, the differential impact of the Black Death led to what was, in effect, a long-run reversal of fortune for laborers: the abandonment of labor coercion in previously highly coercive areas (the west) and the growth of labor coercion in previously less coercive areas (the east). The crucial point here for our analysis is that unmeasured differences in pre-Black Death socioeconomic structures likely bias against our findings, since these structures were historically more coercive towards labor in the west than in the east.

\section{A.24.3 The Free Conservative Party / German Empire Party}

In addition to the Conservative Party, a second party in Imperial Germany represented conservative interests: the Free Conservative Party or German Empire Party (Freikonservative Partei or Deutsche Reichspartei, DRP). In our main analysis, in which we focus on the Conservative Party only, we did not include the Free Conservative Party's vote shares for two reasons: First, different from the Conservative Party, the Free Conservative Party was not exclusively a party representing the interests of traditional landed elites. Instead, industrialists, who embraced capitalism and industrial production, were members, too. Second, the party's program was more moderate than that of the Conservative Party. While Free Conservatives also defended existing social hierarchies, they were less extreme in their polit- 
ical goals. In contrast, the Conservative Party of the early 1870 s went so far as to demand the construction of an "estate society" (Berdahl, 1972, 2-3). For these reasons, vote shares for the Free Conservative Party are not as good an empirical match with the expectations derived from our theory about the Black Death's long-term consequences as vote shares for the Conservative Party.

Nevertheless, in an extension of our empirical test (subsection A.13), we consider joint vote shares of the Conservative Party and the Free Conservative Party. In this additional analysis, we find that all of our results hold.

\section{A.25 The Black Death and Cultures of Political Engagement in the German-Speaking Lands of Central Europe: Tracing Out the Mechanisms}

As shown in Figure 1, Figure 5, and Figure 6 in the main text, the Black Death imposed a particularly severe loss of life in the western areas of what would later become the German Empire, while largely sparing the east. In this section of the appendix, we elucidate how the geographical variation in the in the toll taken by the Black Death spurred economic, social, and institutional changes within the German-speaking lands that ultimately led to highly distinct cultures of political engagement by the dawn of the German Empire.

Our central contention is that areas which experienced drastic loss of life due to the Black Death reduced or eliminated the strictures of serfdom at a relatively early date, whereas those areas with more minor losses from the Black Death maintained or even increased the coercion of the rural workforce. This generated two distinct paths: (1) a virtuous path where the early acquisition of economic freedom begat institutional and cultural changes that reinforced and protected said freedom; and (2) a vicious path where the absence of economic freedom 
contributed to a process of institutional and cultural development that eventually blossomed into full-fledged despotism.

\section{A.25.1 The Virtuous Path}

Areas where labor coercion declined early experienced much greater social mobility, more equitable ownership of and use rights for land, and relatively vibrant towns. As the scope of liberty expanded, these areas also developed robust forms of local self-government. The experience with local self-government, in turn, bequeathed a participatory ethos and a strong capacity for collective action. This created a proto-democratic and (comparatively) egalitarian equilibrium that proved difficult to dislodge. Indeed, subsequent attempts by elites to reintroduce coercive labor practices in these areas ultimately fell flat. In the long run, the absence of major disparities in de facto power between the nobles and other sectors of society, combined with the presence of participatory institutions at the local-level, shaped principality-level institutions (the "Estates") in ways that limited the predations of potentially despotic sovereigns. Liberal political traditions thrived up until the dawning of the Empire.

In establishing the contrast of the west's development with the east, it is important to emphasize that, prior to the Black Death, serfdom was just as widespread in the west and arguably even more onerous. Specifically, to attract peasants to work the lands of the less populated east, lords often had to offer terms of employment that were more favorable than those encountered in the west (Blum, 1957; Carsten, 1954; Friedrichs, 1996). Thus, the initial conditions of peasants were frequently superior in the east and subsequent fundamental changes in those conditions - which we may portray as a "reversal of fortunes" - cannot be interpreted as an artifact of initial conditions favoring the freedom of peasants in the west.

After the Black Death, the conditions of the peasantry and other laborers gradually 
improved in the west while declining precipitously in the east. The immediate consequences of the mortality shock imposed by the Black Death in western areas of the German-speaking lands were similar to what they were in other hard hit parts of Europe. The reduction in the labor supply increased the bargaining power of labor, leading to new rights for peasants like hereditary tenure along with a transition from labor service to cash rents. Towns and merchants grew more wealthy and powerful, and urban laborers earned higher wages. The historical dominance of the nobility was curtailed as land values plummeted (Rösener, 1996; Wilson, 2016).

Among the clearest indicators of the erosion of serfdom in the west - and its rise in the east - is the size of "lord's lands" (i.e., the demesne). This term refers to the amount of agricultural land directly held by the lord of the manor and serviced by serfs in fulfillment of their customary labor obligations. As shown by Ogilvie (2014), the proportion of total land composed of the lord's lands during the early modern period was orders of magnitude greater in the eastern areas of the German-speaking lands than in the western areas. Whereas less than five percent of land was made up of the lord's lands in western and southern Germany, the lord's lands accounted for more than fifty percent of the land in much of the east. Since both areas had roughly equivalent land tenure arrangements prior to the Black Death, this indicates very different trajectories in the two regions.

The post-Black Death changes in land access and use rights had important consequences for social organization at the local level. Given that peasants now enjoyed hereditary tenure and administrative responsibility over expanding tracts of land, they needed to create institutional structures to manage their new assets. Coordination of agricultural activities was particularly important given the widespread use of the two- or three-field agriculture system, which "necessitated constant agreement and close co-operation among all the peasants, and 
some form of central control" (Blum, 1960, 5). This naturally led to the development of institutions for communal self-government.

Although initially focused on matters of agricultural production, such institutions expanded their writ to general administration, taxation, and policing. The peasants themselves were empowered to choose the individuals to oversee these tasks, often from among their own ranks. Slowly but surely, in the western areas of the German-speaking lands, "the village became a self-governing community, or Gemeinde" (Friedrichs, 1996, 249).

For the purposes of our argument, it is crucial to emphasize that this trend towards local self-government: (1) emerged with fullest force after the Black Death; (2) developed specifically as a reaction to the changes in labor freedom and property rights wrought by it. In this respect, the elaboration of the social historian David Sabean (1976, 356, emphasis added) is worth quoting at length:

From the late fourteenth century, peasant autonomy in this realm [agricultural production] increased, for the nobles and ecclesiastical institutions withdrew from the direct exploitation of the land and parcelled out the manor to tenants. The officials were, of course, still resident; but they became more concerned with rent payments and keeping of the peace, and less with coordination of the agricultural round. In this situation, peasant proprietors began to develop independent rules for collective decision-making with regard to harvest and ploughing, gleaning and pasturing. This extended itself directly into the question of sanctions for violations. It came, in the course of time, to the demand that the peasant proprietors be allowed to choose officers to keep the peace, administer village affairs, and the like.

In other words, by forcing peasants to organize themselves to manage agricultural production and resolve conflicts, the transfer of land planted the seeds of a culture of participatory governance. Local-level representation came to have real meaning, as elections - albeit circumscribed ones - became a means of selecting leaders to represent the village. Protodemocracy was born. 
As emphasized in recent research, experiences with proto-democracy can positively shape nature of democratic development for centuries (Bentzen, Hariri and Robinson, 2015; Giuliano and Nunn, 2013; Stasavage, 2020). In the case of the German-speaking lands, the experience of communal self-government was relevant for three reasons: (1) it created a long-lasting ethos of popular participation in local affairs; (2) it created a capacity to act collectively in defense of the rights granted to laborers in the wake of the Black Death; (3) it shaped the structure and efficacy of nascent parliamentary institutions.

The duchy of Württenberg, located in the southwest of the German-speaking lands, provides a good illustration of these dynamics. As in other areas of the region, in the period following the Black Death, "serfdom had lost its rigours, and the manorial system had disintegrated" (Carsten, 1959, 2). Detached from the daily details of agricultural production, the nobility came to exert a relatively minor influence on economic and political affairs. Indeed, the nobility ceased to collect taxes from the peasantry on behalf of the duke, with the consequence that peasant villages became responsible for levying and conveying taxes themselves (Sabean, 1984, 4-5). Given the increased responsibilities accorded to the villages, communal institutions at the local level flourished, and norm of relatively broad participation in the tasks of self-governance became firmly established.

Village governance was based on a system of quasi-citizenship held by the Bürger: adult, married, male householders. The Bürger had the right to use common lands, work in administrative positions in the village, and elect village officials. Male children of a Bürger automatically inherited these rights (Sabean, 1984, 13). It was the Bürger who made up the self-governing community, and it was to the Bürger (in addition to the duke) to whom village officials were ultimately accountable.

Elected and appointed positions within peasant villages were both numerous and critical 
to the functioning of these entities. The highest office was that of the Schultheiß, a village mayor who was popularly elected by the Bürger from among their own ranks. The chief financial officer was the Bürgermeister, responsible for taxation and financial accounts. There was also a village court (Gericht) and a village council (Rat) whose members were elected by the Bürger. Other important elected positions included the schoolmaster and the pastor, both of whom were typically outsiders with specialized training. In addition to the elected offices, there was a wide range of positions that were appointed by the Schultheiß, Gericht, and Rat. These included administrators and supervisors of various sorts, as well as inspectors and police officials (Sabean, 1984, 14-17). All told, to be a member of the Bürger meant directly participating in activities relevant for the welfare of the village, both as a voter and quite often as an official.

Case in point is the small Württemberg town of Wildberg (founded in 1281 and a Württemberg territorial possession since 1440). In 1717, in spite of being home to only 1,328 inhabitants in 300 households, Wildberg featured ninety-five different public offices, ranging from mayoral positions, to councilmen, to myriad types of inspectors. As noted by Wilson $(2016,522)$, this meant that "one fifth of male householders thus held at least one public office, ensuring that authority remained fairly well distributed and a significant proportion of the population retained a meaningful stake in communal affairs."

Without the capacity to exert de facto power, the gains made by peasants in the west - in Württemberg and elsewhere - would have potentially been rolled back. However, the vibrancy of communal life greatly facilitated collective action-including large-scale rebellion - when threats to these gains presented themselves (Brady Jr., 1996). Such threats emerged in the early sixteenth century, when German princes and nobles attempted to reassert their privileges through a combination of tax increases, additional labor obligations, 
and restrictions on movement. Württemberg's peasants responded with force of arms, first in the relatively small-scale Poor Conrad uprising of 1514 and later in the massive Peasants War of 1525. At the height of the latter war, the rebel armies had as many as 300,000 mobilized combatants, a feat that has been deemed "a clear demonstration of the potency of communal government" (Wilson, 2016, 592).

Although the peasant movement was ultimately crushed militarily, castles had been stormed and nobles had been put to death. The uprising sent the message to elites that the costs of re-imposing serfdom in the west would be unacceptably high. As such, in the long run, it was successful in achieving the peasants' overarching aim. The contrast to contemporaneous developments in the east could not be more stark. As will be discussed below, during the sixteenth century, the nobles and princes in the east steamrolled the peasantry with increasingly onerous labor obligations that in effect solidified a condition of near bondage until the nineteenth century.

The rise of local self-governance was important not only for how it structured institutions and norms at the local level, but also for how it influenced institutional development at the macro-level. In the decades following the Black Death, proto-parliamentary institutions called "Estates" emerged in the duchies and principalities throughout German-speaking Europe. These were no less prevalent in the east than in the west. However, the distribution of power within the Estates and the interests represented within them differed substantially based upon whether or not the Black Death had disrupted traditional social structures. In areas of the west, where the nobility experienced a relative decline, representatives of towns exercised considerable influence. ${ }^{52}$ Moreover, the interests of the peasantry were given some consideration and, in several exceptional cases, even enjoyed direct representation via rural

\footnotetext{
${ }^{52}$ Since towns often were centers of manufacturing and trade, the economic basis of their interests was very different from the economic basis of the landed nobility. Thus, town representatives often advocated for different policies than the landed elites did.
} 
communes. By contrast, in the areas of the east, where the nobility remained dominant, agrarian elites wholly dominated the Estates, allowing them to coordinate with princely authorities to maximally exploit the towns and peasantry.

Estates with broader societal representation were ultimately more effective in resisting the despotic tendencies of princes. This was certainly so for the influential Estates of Württemberg - a non-noble led territorial body that in numerous moments in its centuries-long existence (1457-1918) exercised a genuine check on ducal authority and action. Among the lasting institutional achievements of the Estates was the 1514 Treaty of Tübingen, the basis of what became known as Württemberg' ancient constitution. Often the focal point for negotiations between the duchy's rulers and its towns, the treaty was a consequence of the aforementioned 'Poor Conrad' peasants uprising of 1514. Among the concessions granted in the treaty was that "no part of the duchy was to be sold or pawned without [the Estates'] consent; every subject was to be free to leave at his will; the excessive quit-rents were to be scaled down; every duke was to promise with his letter and seal to preserve these liberties before his subjects rendered homage to him (Carsten, 1959, 12). In this respect the treaty is a good example of how the revolutionary potential of the peasantry-itself a consequence of collective self-governance - led peasants' rights to become enshrined within formal parliamentary structures.

Although Württemberg's dukes occasionally disputed the terms of the treaty, more often than not the Estates were able to enforce compliance. For instance, upon his ascension in 1593 duke Frederick delayed confirming the terms of the treaty (until 1595), apparently contributing to myriad violations of the right of free departure. In the face of Frederick's initial hesitance to recognize this right, the Estates utilized their power of the purse strings to force him to concede the point (Carsten, 1959, 43-44). 
In later centuries, conflict between ducal authorities and the Estates focused on the imposition of taxes in order to finance a standing army. Led by the representatives of the towns, the Estates vigorously opposed such efforts, correctly recognizing the threat that a centralized military apparatus would pose to their prerogatives. Although the Estates' defiance of the dukes on this point was not always successful, it did prevent the emergence of a powerful military machine like that which arose in Brandenburg-Prussia. Consequently, the absolutism that characterized the latter state - built on a foundation of strict social hierarchy and military dominance - was not a feature of Württemberg. Rather, the fierce independence of the Württemberg Estates, like others in the west and south of Germany, "preserved the spirit of constitutional government and liberty in the age of absolute monarchy," thereby guaranteeing that the duchy's liberal political traditions could live on into the nineteenth century (Carsten, 1959, 444).

Württemberg is perhaps the best known case of communal self-government contributing to the development of strong proto-parliamentary institutions in the German-speaking lands. However, it is far from unique. The treatment of communalism by Blickle (1986) suggests that such a dynamic was present in a fairly wide range of settings west of the Elbe. Two examples are the bishoprics of Chur and Sitten (in present day Switzerland). In those states, powerful rural communities contributed to the creation of charters that institutionalized the independence of the estates vis-à-vis ruling elites. The 1524 constitutional charter establishing the republic of Graubünden (from the bishopric of Chur) was especially noteworthy in that it explicitly prohibited officials of the bishop from serving in any territorial diet or assembly (Blickle, 1986, 10). 


\section{A.25.2 The Vicious Path}

In tracing out the dynamics of the vicious path, we draw from the experiences of the Germanspeaking lands east of the Elbe that would eventually compose the main territories of the Hohenzollern dynasty: particularly Brandenburg (the seat of the dynasty) and Prussia, but also Pomerania and Magdeburg. In these areas, labor coercion intensified after the Black Death, reinforcing traditional social hierarchies. Urban areas stagnated or declined, pathways for social mobility were virtually non-existent, and land was increasingly concentrated in the hands of agrarian elites. Local self-government had little or no relevance, since all important economic and legal decisions were made by the lord or his officials. Without experience in governing themselves, peasants lacked a capacity for collective action on a large scale. Consequently, they were unable to defend themselves against violations of their customary rights and other abuses.

The proto-parliamentary institutions that emerged in this setting were completely elitedominated. This ultimately made them highly susceptible to manipulation by despoticallyminded princes. In the absence of institutions that empowered a broad societal coalition to check their accumulation of their powers, the Hohenzollern monarchs came to dominate civil society. They did this by coopting the once-dominant nobility, offering them positions of prestige within a growing military-bureaucratic apparatus in exchange for accepting the Crown's total control over taxation and affairs of state. With the nobility tamed, the towns sapped of their vitality, and the peasantry downtrodden and disorganized, the monarchs constructed a powerful autocratic state with the military at its center. Although this new state concentrated political power in the hands of the monarchs, it in no way perturbed the existing social hierarchies in the countryside. To the contrary, it further reinforced them: The progeny of the lords became commanding officers and those of the peasantry became rank- 
and-file soldiers. The culture of deference of the east Elbian societies - forged over centuries of serfdom - was thus institutionalized within the Hohenzollern state-building project.

As suggested by our theory, the lands east of the Elbe differed greatly from those of the west in their responses to the economic dislocation produced by the Black Death. Whereas in the latter the management of land was devolved to the peasantry, in the former the exact opposite occurred. During the fifteenth and sixteenth centuries, the east Elbian landlords - commonly referred to as Junkers - rapidly expanded and consolidated their lordly estates. The Junkers were what Max Weber called "operating landlords:" hands-on managers of commercial agricultural enterprises dedicated to the production of grain for export (Weber, 1946, 380). Agricultural production took place on large properties serviced by an actively coerced labor force; in these respects, they were of a piece with the latifundia of ancient Rome and colonial Latin America.

Part and parcel of the expansion of the lord's lands was the loss of customary rights enjoyed by the peasants and the imposition of new labor obligations. This process has been dubbed the 'second serfdom' because it supposedly returned the peasantry of the eastern lands to a servile status akin to what had existed prior to the onset of German colonization in the twelfth century (Blum, 1957). The specific details of the new labor restrictions varied by time and place, but all represented grave impediments to freedom. ${ }^{53}$

In Brandenburg, peasants could only leave their estates with the written authorization of their lords. During harvest season, they could be forced to perform unlimited amounts of service on the lord's lands. The freedom of peasants' children was also sharply curtailed. Peasant children could be forced to serve the lord for three years, upon pain of imprisonment should they refuse. Similar restrictions were in force in Prussia, which required peasant children to serve the lord for an indefinite period of time and forced the daughters of peasants

\footnotetext{
${ }^{53}$ The following description of labor obligations draws from Carsten (1954, 147-164).
} 
to pay the lord a fee should they leave the estate to marry. Most onerous of all were the ordinances of Pomerania, which subjected peasants to potentially unlimited labor services, eliminated all hereditary rights to land, and imposed severe restrictions on movement. In practice, two to three days per week of uncompensated labor working the lord's lands was typical in the east during this period, though even more extensive labor service was not uncommon (Cerman, 2012, 70-87). As we shall see below, large-scale resistance to these measures was infeasible given institutional impediments to peasant collective action.

Underlying the system of serfdom was the imposition of terror by the local enforcers of the lord. Peasants who refused to work the lord's lands or dragged their feet in doing so could receive corporal punishment, imprisonment, or worse. For instance, in Brandenburg in the late sixteenth century, the cost of recalcitrance in one village was that "the lord's men brutally invaded the village, shooting firearms at its members." In another, the lord's men "took eight serfs prisoner, tied them to horses, and dragged them across country." In yet another, "they confiscated and slaughtered serfs' cattle; if they found the male householder absent they ravaged the farm and took the women prisoner" (Ogilvie, 2014, 38).

The centralization of Junker control over agricultural production and the reliance on repression had predictable consequences for the nature of local political institutions. Selfgovernment, at least in the vibrant form which emerged in the west, was a non-starter. This was the case in spite of the fact that, due to the dynamics of German colonization, some of the core features of village organization in the east were similar to those of the west prior to the Black Death (Blum, 1971). As the second serfdom took root, legal institutions at the local level were structured to legitimize repression and to prevent peasants from seeking redress for the abuses of their lords. The lords controlled the manorial courts, which readily provided a legal imprimatur for the whippings and other sanctions meted out to disobedient serfs 
(Clark, 2006, 161). There was no easy escape from this local tyranny. In Brandenburg, for instance, to prevent peasants from directing complaints about their lords to the margrave's court in Berlin, the margrave decreed that wantonly complaining peasants were "to be put into the dungeon" (Carsten, 1954, 157). In the countryside, economic and political power belonged solely to the lord:

Local dominance was complete, for in the course of time, the Junker had become not only an exacting landlord, hereditary serf master, vigorous entrepreneur, assiduous estate manager, and nonprofessional trader, but also the local church patron, police chief, prosecutor, and judge... government of, by, and for the landed aristocracy was the preponderant pattern of rulership in the east German principalities (Rosenberg, 1958, 30-31).

Without a sustained experience of meaningful self-governance, the capacity for cooperation and collective action among the peasants of the eastern lands was substantially weaker than it was in the west. This was particularly evident during the early sixteenth century, when the quiescence of the peasants of the east contrasted sharply with the steady hum of peasant revolt in the southwest. In spite of a steady decline in their freedoms, the peasants of the east did not transform grievances into action. The most noteworthy attempt of eastern peasants to collectively to defend their rights was the East Prussian peasant rising of 1525, an extremely minor affair relative to that which took place in the southwest. All told, the East Prussian uprising had about 5,000 peasants in arms at its height, less than 2\% the size of the contemporaneous insurgency in the southwest (Zins, 1959, 183). It was put down quickly, without appreciable loss of life or property. The costs of maintaining serfdom through repression were low, and the nobles knew it.

The supremacy of the landed nobility left its mark on institutional development in the principalities. In contrast to the experience of the west, the Estates of the east were almost exclusively dominated by the nobility. Within these proto-parliamentary bodies, the 
representation of the towns was extremely weak and the peasants had no voice whatsoever. Consequently, the Estates were utilized by the Hohenzollern monarchs - the rulers of what would later become known as the Kingdom of Prussia - to collude with the nobility in order to extract maximal resources from the towns and the peasantry.

Such collusion was particularly evident in the unequal burdens of taxation. Whereas the landed nobility was for centuries exempted from taxation, the towns were burdened with an excise tax on a wide array of goods and services. This placed the towns at a major competitive disadvantage vis-à-vis the countryside, further encouraging their decline (Carsten, 1954; Clark, 2006). In terms of policymaking for the countryside, the nobles used their leverage within the Estates to push for an extension of their traditional privileges, thus facilitating the appropriation of peasant lands and the eviction of unruly peasants. The upshot was that the interests championed by the Estates were contrary to those of the vast majority of individuals who populated the societies within which they operated.

The narrow social bases of the eastern Estates ultimately made them susceptible to attack by the Hohenzollern monarchs. However, the Estates of the east were not initially weak; indeed, for a time they were able to jealously guard their control over the monarchs' ability to tax, appoint officials, and establish alliances. Yet the balance of power between sovereign and lord changed in the wake of the bloody military conflicts of the seventeenth century. Animated by the desire to unite their varied territorial possessions into a single state with true military prowess, the Hohenzollerns committed themselves to centralizing control over fiscal and military matters, thereby stripping the Estates - and the nobles who controlled them - of real political power. With no broader societal support for the Estates beyond the war weary nobility, it was relatively easy for the Hohenzollern monarchs to use the threat of arms to first defang the Estates then eventually do away with them altogether. 
With the Estates cowed, the Hohenzollern dynasty concentrated its efforts on building a powerful standing army. Under Frederick William I, the dynasty instituted the socalled cantonal regime of conscription, a decentralized military reserve system that provided Brandenburg-Prussia with the fourth largest army in Europe (despite being thirteenth largest in population) (Clark, 2006). To pay for this endeavor, the military took over authority for taxation from the Estates, and it eventually became responsible for general administration of the economy. New military-led agencies such as the General Commissariat (which managed revenue from royal lands) and the General Finance Directory (which handled taxation) became the most important administrative units in the Hohenzollern lands. Populated by officials responsible solely to the sovereign, these new agencies constituted the embryo of a burgeoning military-bureaucratic apparatus, one that would permit the Hohenzollern monarchs to rule with few societal constraints on their exercise of power. Autocratic rule in the newly dubbed Kingdom of Prussia (which encompassed all the Hohenzollern territories) was thus firmly established.

The rise of autocracy in the eastern lands was based on a Faustian bargain. The bargain had two components. First, the nobles would give up their veto power over affairs of state in exchange for the right to rule their estates at their whim and for special privileges conferred to their agricultural enterprises. ${ }^{54}$ Second, they themselves would come to populate the lion's share of key offices in the newly created military bureaucracy; this allowed them to enjoy a privileged status relative to the society at large but required strict subordination to the monarch. The Junkers thus became a 'service aristocracy' inextricably intertwined with the Hohenzollern state. This was so much the case that, reflecting on the disintegration of German democracy, the economic historian Alexander Gerschenkron concluded that the norms

\footnotetext{
${ }^{54}$ The interpretation of the rise of autocracy in Prussia as cementing a bargain between the nobles and the Hohenzollern rulers is a common one. See, inter alia, Rosenberg (1958), Carsten (1954), Büsch (1997), and Clark (2006).
} 
of the Junkers constituted nothing less than the "spirit of Prussianism" itself (Gerschenkron, $1966,24)$.

What was the content of the norms associated with the Junkers? There were two components. The first was an unconditional deference to one's superiors. This was facilitated by the overlapping hierarchies of blood and office. The hereditary hierarchy that persisted in the countryside was transported root-and-branch into the functional hierarchy of the military and later (to a lesser extent) into the civil bureaucracy. In the view of Hohenzollern monarchs like Frederick II it was only appropriate that the fierce taskmasters of the rural estates be the officers of the army, since common soldiers ought "fear their officers more than any danger to which they might be exposed" (quoted in Rosenberg, 1958, 60). The second component was a glorification of militarism. The training of Prussian cadets extolled the virtues of a brutal, Spartan ideal-type of military discipline, a tradition of military instruction that continued on into the Third Reich (Roche, 2013). Since service in the military was so broad, with large swathes of the population in rural areas drawn into conscription, and since the military's role in society was so multifaceted, the values of the military ultimately became those of much of Prussian society (Büsch, 1997; Willems, 1986).

All told, centuries of serfdom in the eastern lands bequeathed a weak civil society, one that was militaristic but divided and obedient. Such conditions tend to favor the development of despotism (Acemoglu and Robinson, 2019; Stasavage, 2020). The experience of the western lands suggests that it did not have to be this way. Had the mortality shock introduced by the Black Death been more profound, the eastern nobles very well may have been forced to make concessions to the peasantry comparable to those which occurred in the west. In this alternative scenario, a self-sustaining path towards greater freedom may have emerged, and the historical differences between west and east would have been much less stark. 